\title{
HYDROLOGY OF AREA 58, NORTHERN GREAT PLAINS AND \\ ROCKY MOUNTAIN COAL PROVINCES, COLORADO AND UTAH
}

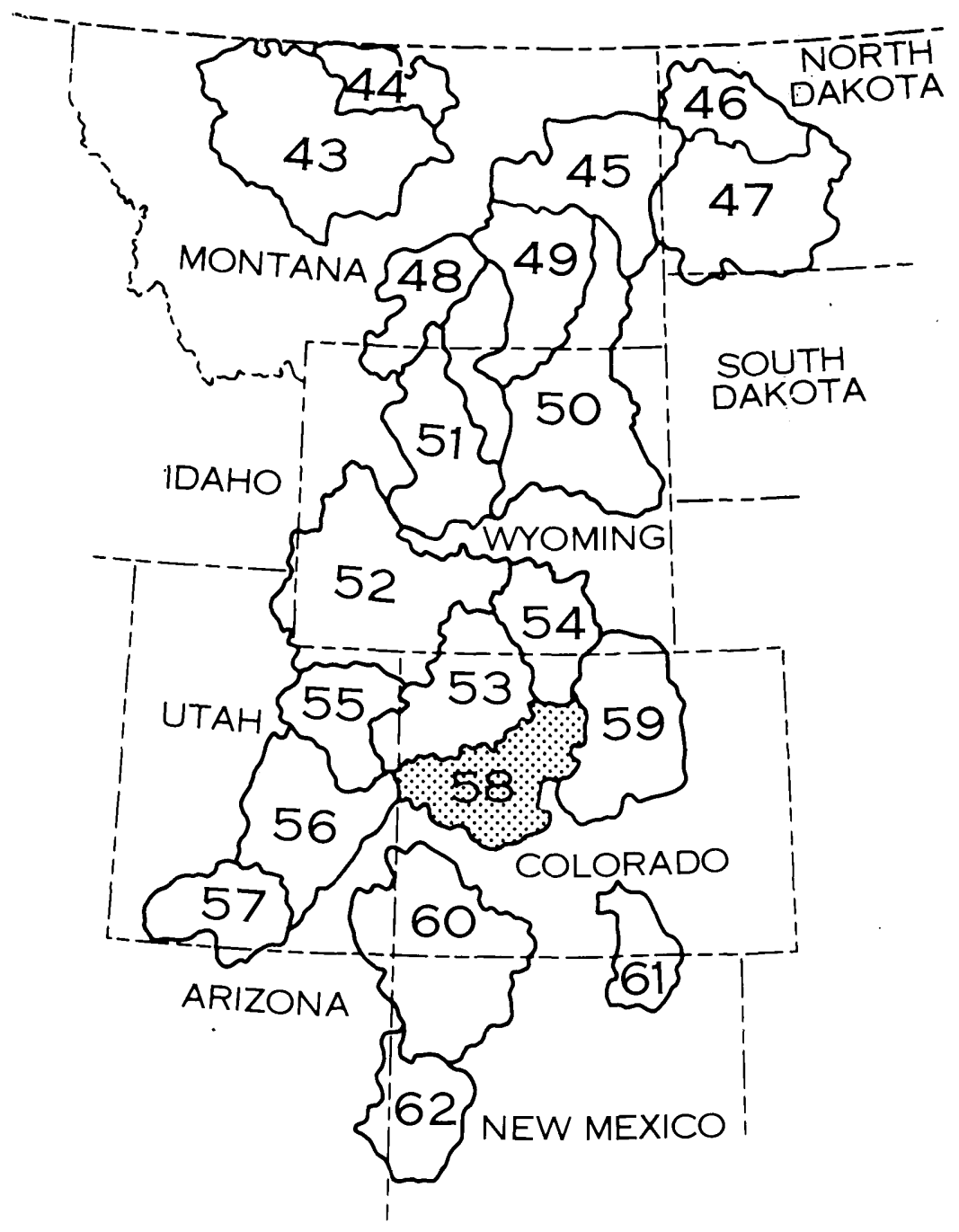

- COLORADO RIVER

- GUNNISON RIVER

- ROARING FORK RIVER

- EAGLE RIVER

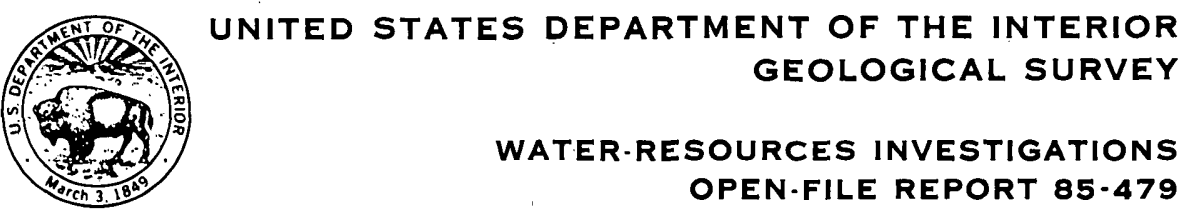


$\cdots$

$\sim$ 


\section{HYDROLOGY OF AREA 58, NORTHERN GREAT PLAINS AND ROCKY MOUNTAIN COAL PROVINCES, COLORADO AND UTAH}

BY

THOMAS H. CHANEY, GERHARD KUHN, TOM BROOKS, AND OTHERS

U.S. GEOLOGICAL SURVEY

WATER-RESOURCES INVESTIGATIONS

OPEN-FILE REPORT $85 \cdot 479$
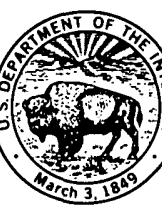

LAKEWOOD, COLORADO JANUARY 1987 


\section{DEPARTMENT OF THE INTERIOR}

DONALD PAUL HODEL, Secretary

\section{UNITED STATES GEOLOGICAL SURVEY}

Dallas L. Peck, Director

For additional information write to:

\section{District Chief}

U.S. Geological Survey MS 415

Box 25046, Denver Federal Center

Lakewood, CO 80225 


\section{CONTENTS}

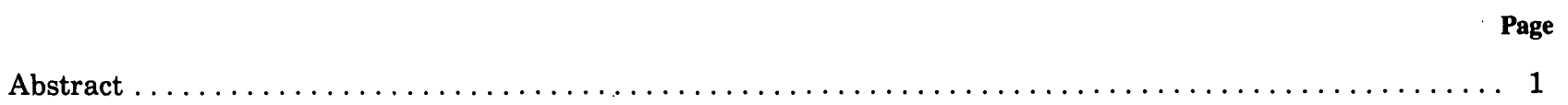

1.0 Introduction

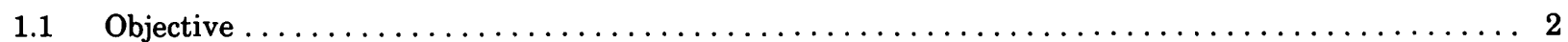

F. A. Kilpatrick

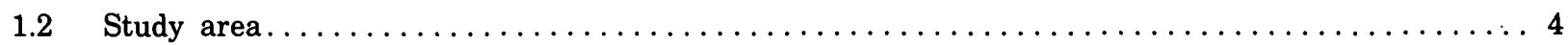
Thomas' H. Chaney

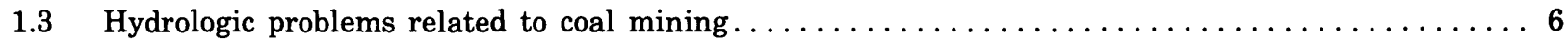
Thomas H. Chaney and Randolph S. Parker

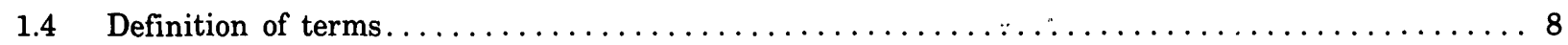

2.0 Physical features

Thomas H. Chaney

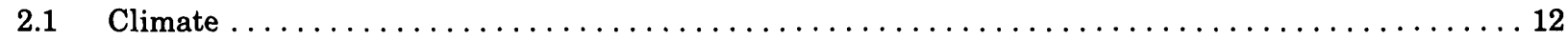

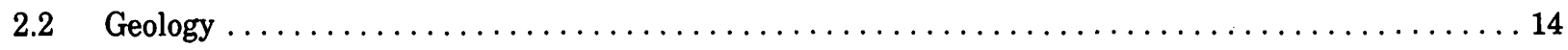

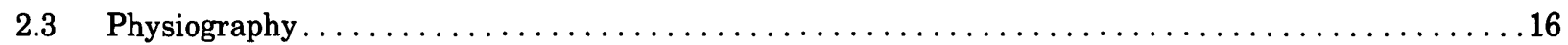

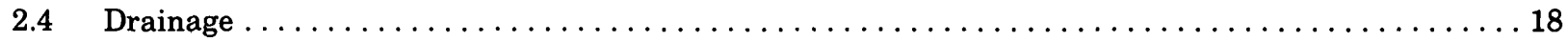

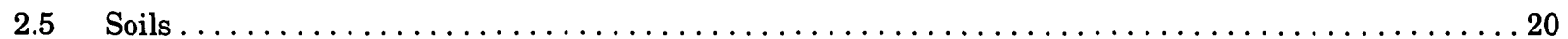

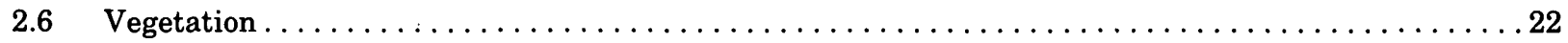

3.0 Resource use

Thomas H. Chaney

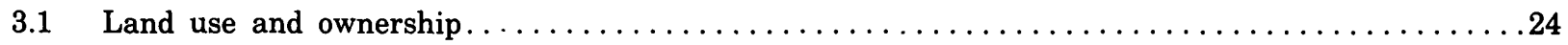

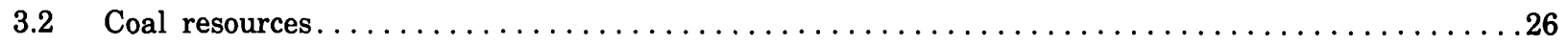

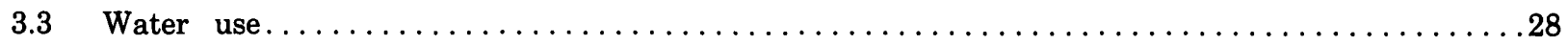

4.0 Surface-water quantity

Gerhard Kuhn

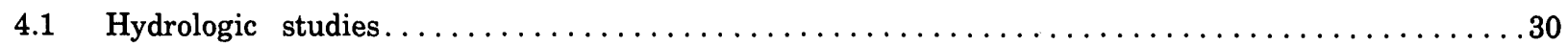

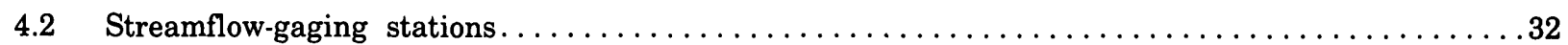

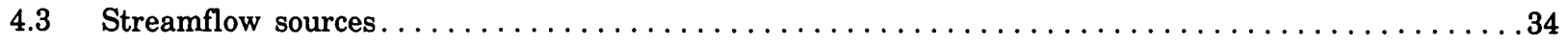


Page
.

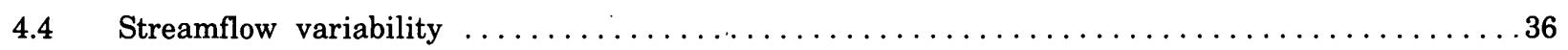

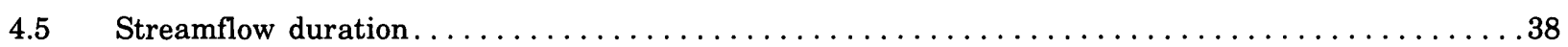

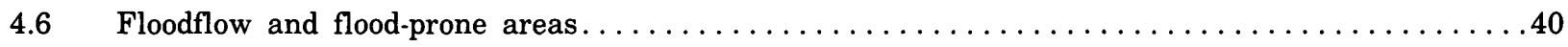

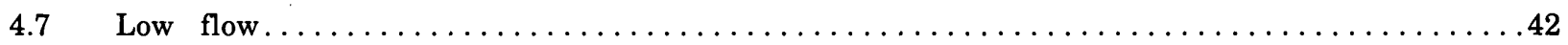

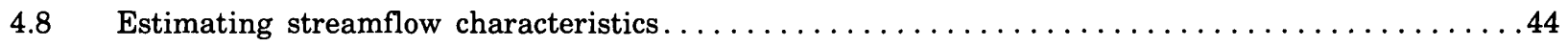

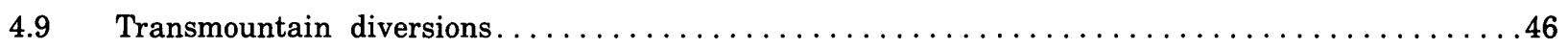

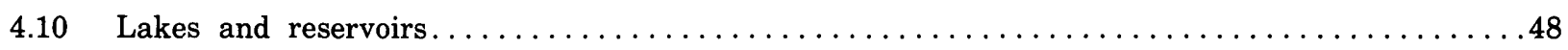

5.0 Surface-water quality

Thomas H. Chaney

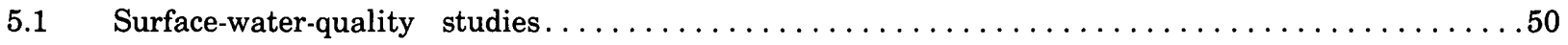

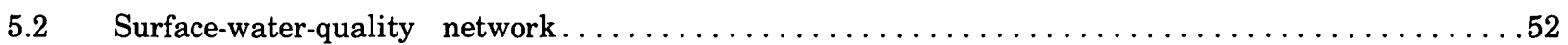

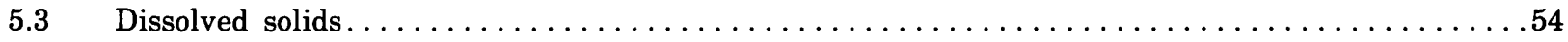

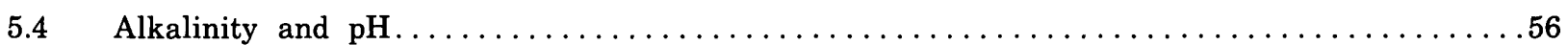

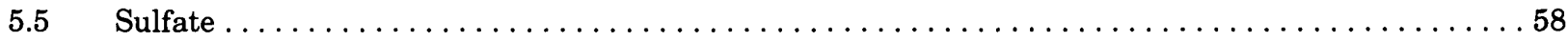

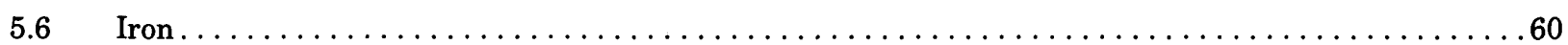

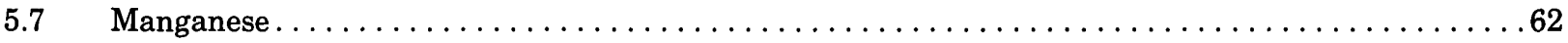

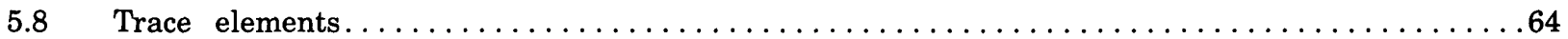

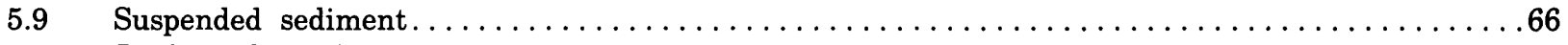
Barbara C. Ruddy

6.0 Ground water Tom Brooks

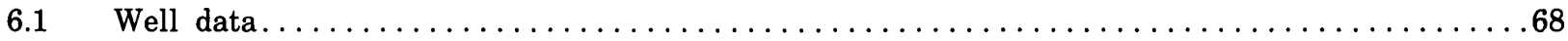

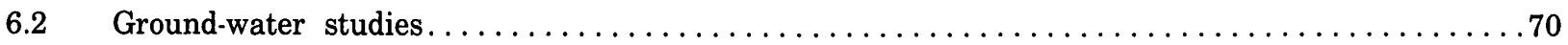

7.0 Ground-water quality

Tom Brooks

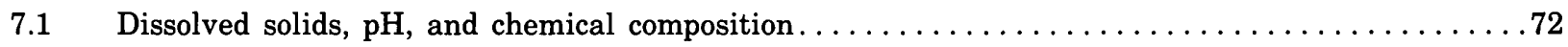

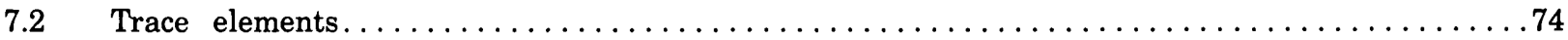


8.0 Water-data sources

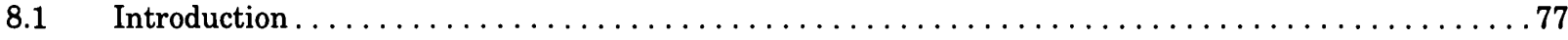

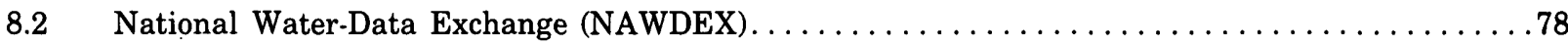

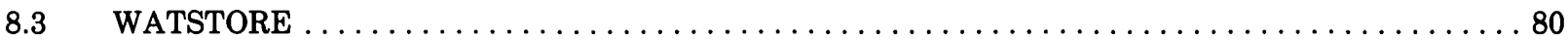

8.4 Index to water-data activities in coal provinces. $\ldots \ldots \ldots \ldots \ldots \ldots \ldots \ldots \ldots$

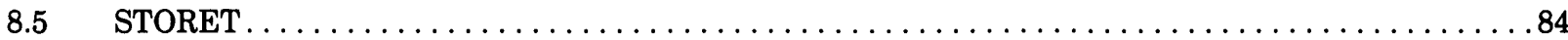

9.0 Supplemental information for Area 58

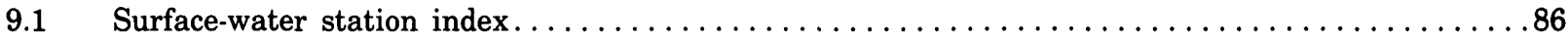

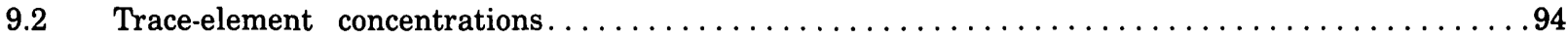

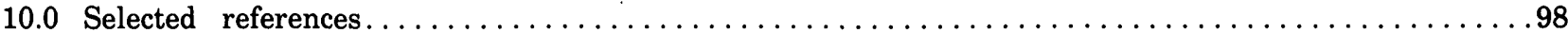




\section{CONVERSION FACTORS AND RELATED INFORMATION}

\section{For the convenience of readers who may want to use the International System}

of Units (SI), the data may be converted by using the following factors:

Multiply inch-pound units

acre-foot (acre-ft)

acre-foot per year (acre-ft/yr)

cubic foot per second $\left(\mathrm{ft}^{3} / \mathrm{s}\right)$

cubic foot per second per square mile $\left[\left(\mathrm{ft}^{3} / \mathrm{s}\right) / \mathrm{mi}^{2}\right]$

foot (ft)

foot per mile $(\mathrm{ft} / \mathrm{mi})$

gallon per minute (gal/min)

inch (in.)

inch per hour (in./h)

micromho per centimeter at

$25^{\circ}$ Celsius $\left(\mu \mathrm{mhos} / \mathrm{cm}\right.$ at $25^{\circ} \mathrm{C}$ )

mile (mi)

million gallons per day (Mgal/d)

square mile $\left(\mathrm{mi}^{2}\right)$

ton per square mile per year [(ton $\left.\left./ \mathrm{mi}^{2}\right) / \mathrm{yr}\right]$

degree Fahrenheit $\left({ }^{\circ} \mathrm{F}\right)$

short ton $(2,000 \mathrm{lbs})$

\begin{tabular}{|c|}
\hline By \\
\hline $\begin{array}{r}1,233 \\
0.001233\end{array}$ \\
\hline 1,233 \\
\hline 0.02832 \\
\hline 0.01093 \\
\hline 0.3048 \\
\hline 0.1894 \\
\hline 0.06309 \\
\hline 25.4 \\
\hline $\begin{array}{l}25.4 \\
2.54\end{array}$ \\
\hline 1.000 \\
\hline 1.609 \\
\hline 0.04381 \\
\hline 2.590 \\
\hline 0.3503 \\
\hline${ }^{\circ} \mathrm{C}=5 / 9\left({ }^{\circ} \mathrm{F}-32\right)$ \\
\hline 0.907 \\
\hline
\end{tabular}

To obtain SI units

cubic meter

cubic hectometer

cubic meter per year

cubic meter per second

cubic meter per second per square kilometer

meter

meter per kilometer

liter per second

millimeter

millimeter per hour centimeter per hour

microsiemens per centimeter at $25^{\circ}$ Celsius

kilometer

cubic meter per second

square kilometer

metric ton per square kilometer per year

degree Celsius

metric tons $(1,000 \mathrm{~kg})$ 


\section{HYDROLOGY OF AREA 58, NORTHERN GREAT PLAINS AND ROCKY MOUNTAIN COAL PROVINCES, COLORADO AND UTAH}

BY

THOMAS H. CHANEY, GERHARD KUHN, TOM BROOKS, AND OTHERS

\begin{abstract}
Hydrologic information and analyses are needed to aid in decisions to lease Federally owned coal and to prepare the necessary environmental assessments and impact-study reports. This need has become even more critical with the enactment of the Surface Mining Control and Reclamation Act of 1977. This report, which is one of a series covering the Nation's coal areas, presents information thematically by describing single hydrologic topics through the use of brief texts and accompanying maps, graphs, or other illustrations. The topics encompass the complete physical and hydrologic setting of the area.
\end{abstract}

ABSTRACT

Area 58, located primarily in west-central Colorado, is in the Southern Rocky Mountain and Colorado Plateau physiographic provinces. The area consists of 13,132 square miles of diverse geology, topography, and climate. The diversity results in a broad array of hydrologic characteristics.

The Colorado River is the principal river draining the region. The headwaters of the Colorado and most of its tributaries originate in the mountains forming the eastern boundary of the area. This boundary also is the Continental Divide.

The major tributaries to the Colorado River included in Area 58 are the Gunnison, the Roaring Fork, and the Eagle Rivers. The mountains are composed of Precambrian metamorphic and igneous rocks, while the western part of the area is underlain by more recent sedimentary deposits. Elevations range from more than 10,000 feet above sea level in the mountains to less than 4,500 feet at the Colorado-Utah border. Precipitation in the mountains can exceed 40 inches annually, most of it in the form of snow. In the western basins, precipitation frequently is less than 20 inches per year. Most of the runoff then is a result of snow melting in the spring.

Surface water is the principal source of water supplies in the area, and irrigation is the major water use. Ground-water supplies are mainly from wells completed in alluvium or fractured bedrock. Greatest yields occur in valley-floor alluvium deposits.

All coal mines in the basin but one are underground. Production from these mines during 1982 totaled almost
4 million tons. Coal from Area 58 typically is bituminous. Some anthracite coal is present. Both types of coal have low sulfur content. Significant oil-shale deposits also occur in the area. The Federal government is the principal landowner in the region, and most of the land is national forest or grazing land.

Surface-water quality is best in the mountains. Dissolved-solids concentrations in the Colorado River increase an average of 647 milligrams per liter as it flows through the area. The causes of this increase are nearly equally divided between natural sources and irrigation activities in the sedimentary basins. The climate in these basins is semiarid, and the soils are not adequately leached. This results in large dissolved-solids concentrations when flows occur in the ephemeral streams draining these areas. Other water-quality constituents examined in the report showed little or no direct effect from coal-mining activities.

Ground-water quality generally is best in wells completed in Quaternary deposits. The quality of ground water varies significantly depending on the formation being tapped. Several formations such as the Mancos Shale produce saline water. Concentrations of several major elements and trace elements in the ground water can be large enough to limit water uses. Among those elements exceeding recommended or required standards for use are calcium, chromium, iron, manganese, and lead.

The U.S. Geological Survey operates a network of hydrologic stations to measure the streamflow and waterquality conditions. This network currently includes 97 stations collecting streamflow data and 12 stations collecting water-quality data. Information is available for many surface- and ground-water sites measured in the past. Data available include rate of flow, water levels, and water quality. These data are available from the U.S. Geological Survey either in published reports or from computer storage through the National Water-Data Exchange (NAWDEX) or the National Water-Data Storage and Retrieval System (WATSTORE). 


\title{
1.0 INTRODUCTION \\ 1.1 Objective
}

\section{Report Summarizes Available Hydrologic Data}

\author{
Existing hydrologic conditions and sources of information are identified to \\ aid leasing decisions and preparation and appraisal of environmental \\ impact studies and mine-permit applications.
}

Hydrologic information and analysis are needed to aid in decisions to lease Federally owned coal and to prepare the necessary environmental assessments and impact study reports. This need has become even more critical with the enactment of Public Law 95-87, the "Surface Mining Control and Reclamation Act of 1977." This Act requires an appropriate regulatory agency to issue mining permits based on the review of permit application data to assess hydrologic impacts. This need is partly fulfilled by this report, which broadly characterizes the hydrology of Area 58 in west central Colorado and eastern Utah, a part of the Northern Great Plains, and Rocky Mountain Coal Provinces (fig. 1.1-1). This report is one of a series that describes coal provinces nationwide.

This report provides general hydrologic information by means of a brief text with an accompanying map, chart, graph, or other illustration for each of a series of water-resources-related topics.
Summation of the topical discussions provides a description of the hydrology of the area. The information contained herein will be useful to Federal agencies in leasing and management of Federal coal lands; to surface-mine owners, operators, and others preparing permit applications; and to regulatory authorities evaluating the adequacy of the applications.

The hydrologic information presented herein or available through sources identified in this report will be useful in describing the hydrology of the "general area" of any proposed mine. This hydrologic information will be supplemented by the lease applicant's specific site data as well as data from other sources. The purpose of the specific site data is to provide a detailed appraisal of the hydrology of the area in the vicinity of the mine and the anticipated hydrologic consequences of the mining operation. 


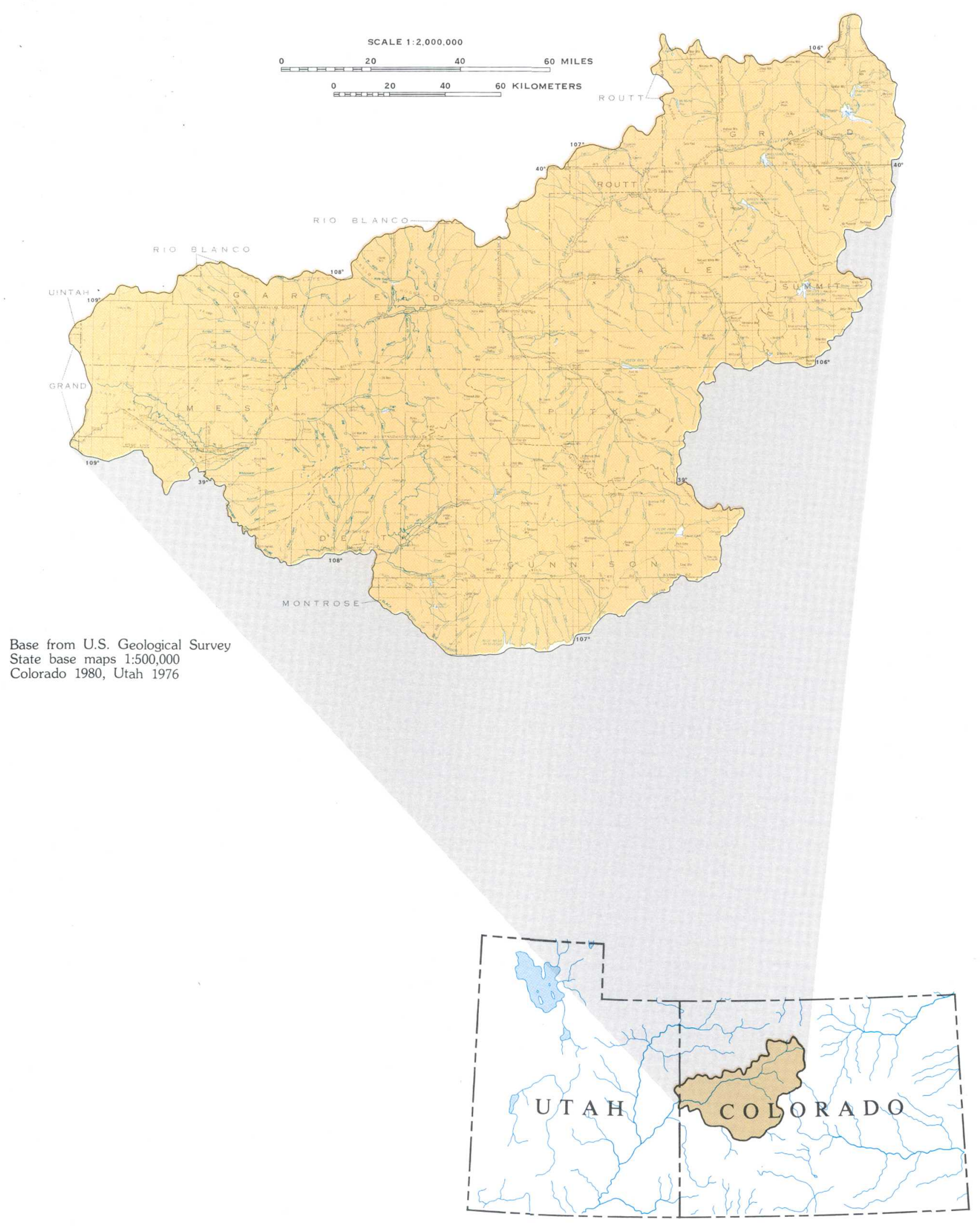

Figure 1.1-1 Location of Area 58. 


\title{
1.0 INTRODUCTION--Continued \\ 1.2 Study Area
}

\section{Area 58 is in the Northern Great Plains and Rocky Mountain Coal Provinces}

\author{
Drained by the Colorado and the Gunnison Rivers, Area 58 \\ is rural in character and has diverse physical features.
}

Coal provinces have been divided nationwide into hydrologic reporting areas consisting of hydrologic units (drainage basins) selected according to size, location, and presence of coal resources. Area 58, located in west-central Colorado and eastern Utah, is one of the report areas in the Northern Great Plains and Rocky Mountain coal provinces (see front cover). The Colorado River and its tributaries, the Gunnison, the Roaring Fork, and the Eagle Rivers drain the 13,132 square-mile area (fig. 1.2-1). The headwaters of the Colorado River are included in the study area, and the Continental Divide forms the eastern boundary.

The region has diverse topography, geology, climate, and vegetation. Physical features range from high mountains in the east to flat plateaus in the west. Outcrops of geologic strata ranging in age from Precambrian to Quaternary can be found throughout the area. Elevations range more than 10,000 feet from east to west. Largely as a result of the varied topography, the climate changes from semiarid in the west with less than 20 inches of annual precipitation to alpine in the east with more than 40 inches of annual precipitation. The dramatic changes in elevation and climate have resulted in varied vegetation communities. These communities range in variety from desert shrub associations to spruce-fir forests and alpine associations.

All or part of 13 counties are in the area. The 11 Colorado counties are Delta, Eagle, Garfield, Grand, Gunnison, Mesa, Montrose, Pitkin, Rio Blanco, Routt, and Summit. The two Utah counties are Grand and Uintah. The region is primarily rural, and the city of Grand Junction is the major population center (population 28,000). Other principal cities within the region are Aspen, Delta,
Fruita, Glenwood Springs, Gunnison, and Rifle. The counties of Delta, Garfield, Mesa, and Montrose have the largest rural populations, all with populations greater than 20,000 .

Significant mineral resources other than coal have been found in the region. The Colorado mineral belt is located along the eastern edge of the area, and gold and silver deposits are what attracted the first settlers to the area. Several gold and silver mines are still active, but now other metals have increased in importance; these include lead, zinc, molybdenum, and copper. Several oil and gas fields are actively producing in the Roan and Parachute Creek area. This area also contains significant oil-shale deposits and is the location of the only active oil-shale production facility. Uranium deposits also have been actively mined in the region.

Mining and agriculture traditionally have been the two most important economic activities in the region. However, because of the region's great scenic beauty, tourism has been increasing in importance. Several national parks and recreation areas are located at least partially within the area, and a number of new ski resorts have been built in recent years.

Agricultural activities include both crop and livestock production. Large numbers of both sheep and cattle are raised in the western counties. Principal crop production is hay or alfalfa, but a number of grains also are grown. Delta, Mesa, and Montrose Counties are the principal fruitproducing areas in Colorado. Most of the crop production including forage crops is dependent on irrigation. Extensive forests exist in the region, but timber production has not been a significant economic factor. 


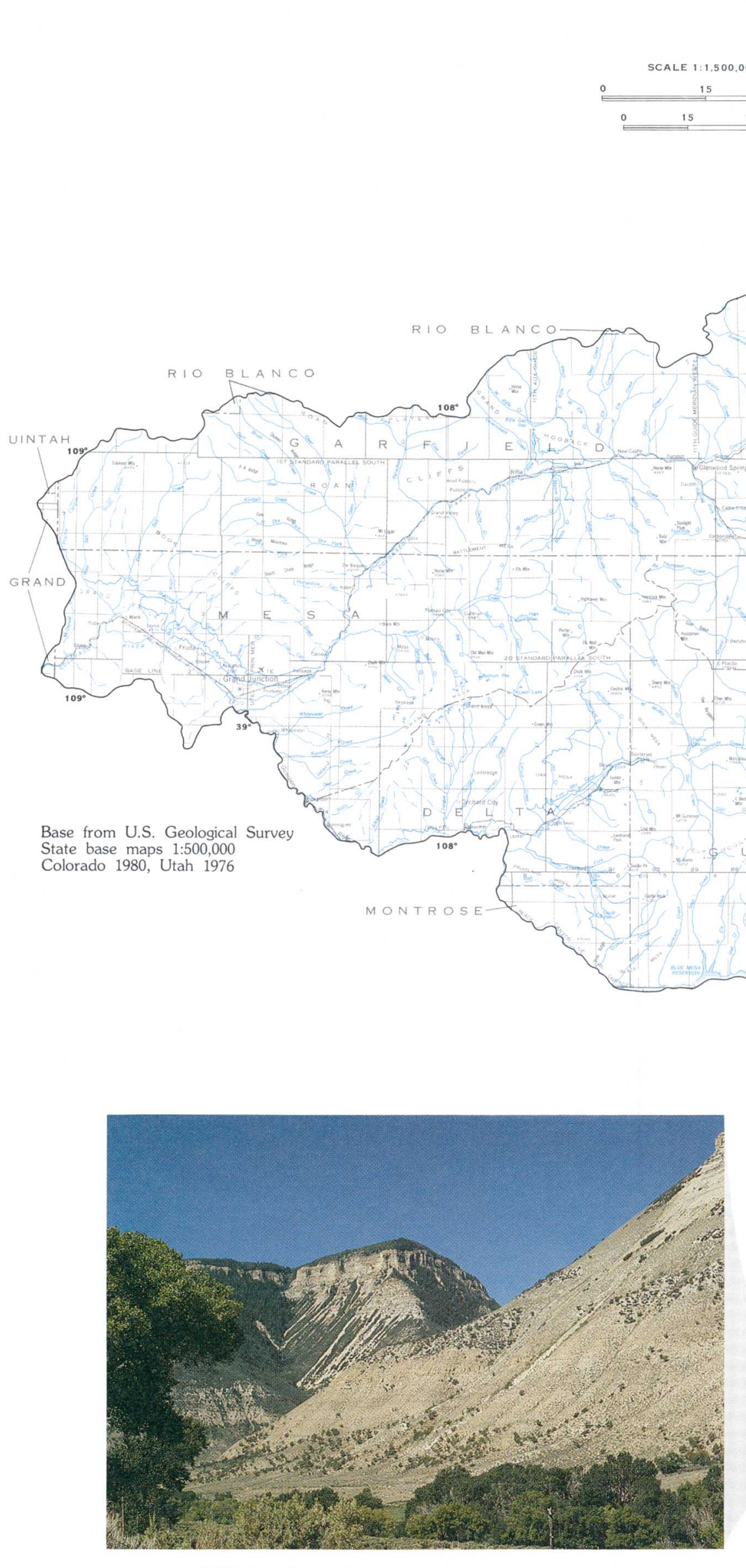

Cliffs bordering Parachute Creek where oil shale development is occurring.
Figure 1.2-1 Area 58 study area.

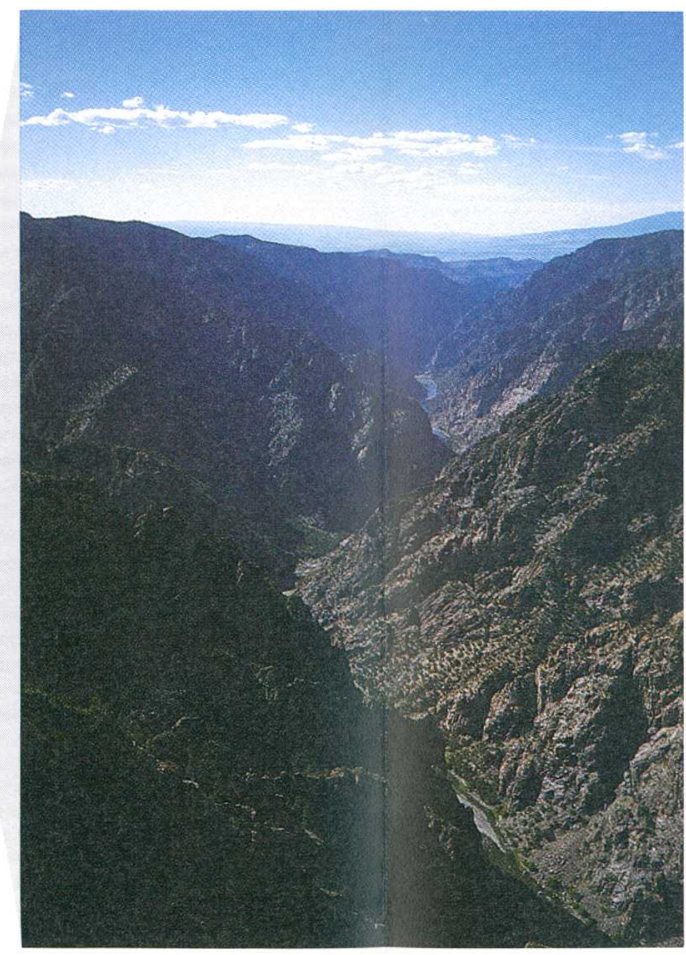
Black Canyon of the Gunnison, the deepest
of the canyons that typify the plateau part

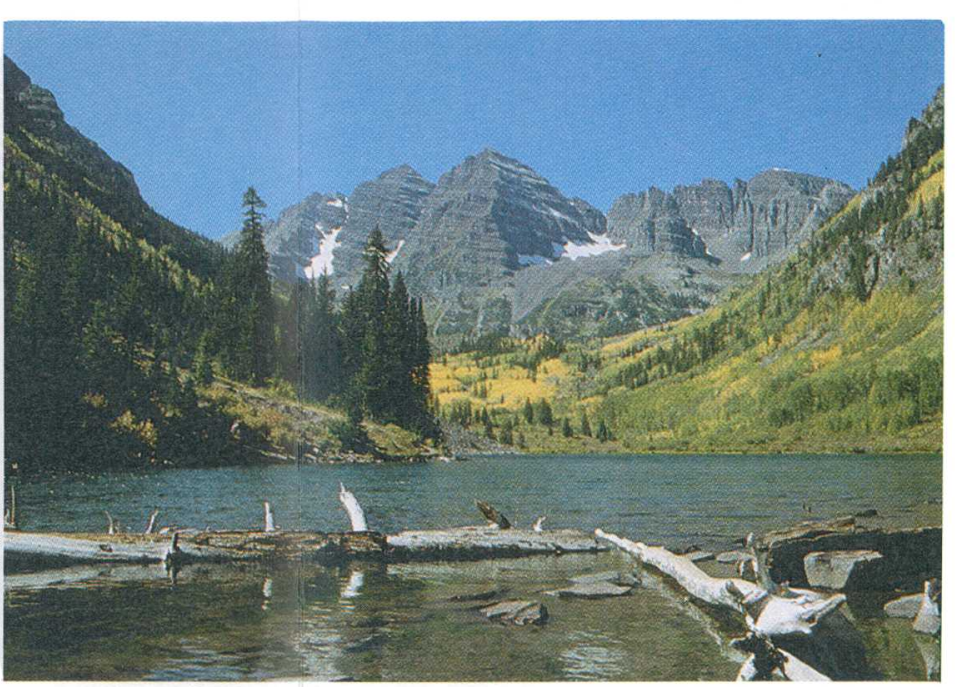

Maroon Bells, near Aspen, one of the most photographed spots istrates the beauty of Area 58 .

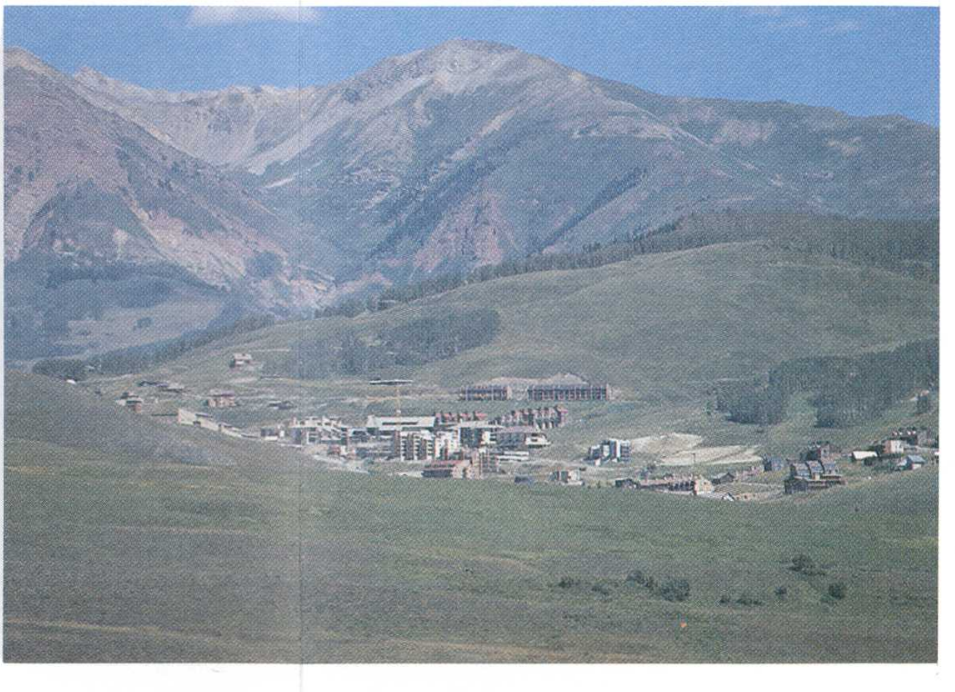
New housing construction associated with the
Crested Butte ski resort. 


\title{
1.0 INTRODUCTION--Continued \\ 1.3 Hydrologic Problems Related To Coal Mining
}

\section{Water Quality Can Be Degraded}

\author{
Coal-mining operations can increase acidity, sulfates, \\ and other minerals in surface and ground water.
}

The hydrologic setting of Area 58 with respect to coal mining is somewhat similar to that of other coal areas in the Rocky Mountain coal province. The major river, the Colorado River, and its principal tributaries all have their headwaters in mountains some distance from the coal areas. These mountains supply most of the water to the river systems from deep snowpacks that melt during late spring and summer. The mountains, generally composed of igneous and metamorphic rock, are very different geologically from the downstream areas, which are underlain by sedimentary rock. Most of the water quantity and its associated water quality, then, are foreign to the downstream environment through which the water merely is transported. The major coal-producing area is divided between these different hydrologic regions, the high mountainous environment and semiarid downstream environment. These diverse environments make measurement of the system difficult because both the major streams and the small tributaries draining the coal-mining areas must be measured.

Coal mining occurs through either surface or underground mining methods depending on economic factors such as terrain, amount of overburden, and thickness of the coal seam (fig. 1.3-1). Because of the nature of the coal beds in Area 58, most coal is removed by underground mining methods. At present, only one surface mine is operating in the area.

Both types of mining operations can affect the hydrologic environment, but each mining method impacts particular components of the hydrologic cycle differently. For example, the amount of spoil disposal associated with underground mining is quite small compared to the amount generated by complete overburden removal in surface mining. The presence of spoil piles from either source exposes new material to weathering, which can result in an increase in mineral content in surface waters. Water percolating through the spoil bank also can affect ground-water quality by increasing its mineral content. Runoff from spoil piles can be acidic, and it can contain large concentrations of constituents such as sulfate, calcium, magnesium, manganese, iron, or zinc (U.S. National Research Council, 1981). Although the amount of spoil material is relatively small in underground mining operations, this form of mining creates underground cavities that can fill with water. The water may stay in these cavities for long periods of time increasing the concentrations of dissolved constituents. The process of dewatering mines during active mining, either surface or underground, can affect surface-water quality by pumping water with large dissolved-solids concentrations into the streams.

Placement of the spoil also can be a problem, particularly in the areas of steep terrain. If improperly placed, heavy runoff can cause the spoil to erode or slide impacting water quality and streamflow. In the western United States, revegetation of the spoil can be a problem in semiarid and arid areas because of lack of moisture. Also, soils often are thin in the west, increasing the difficulty of establishing new vegetation. In underground mining, the quantities of spoil are less, but often the location for spoil placement is limited.

Water-quality problems associated with acid mine drainage in Area 58 are minimal because of the large buffering capacity of the stream waters. The semiarid climate throughout much of the coal area also helps prevent the formation of acid water by minimizing the amount of runoff. Overall, some increases in dissolved solids, particularly sulfate, and increases in total recoverable trace-element concentrations are likely as a result of mining. Because the $\mathrm{pH}$ of the water is neutral to basic and because bicarbonate is abundant, trace elements largely remain in the suspended phase, sorbed to the fine-grained sediment. Increases in total recoverable trace-element concentrations, then, usually are associated with increases in suspendedsediment concentrations.

Coal-mining operations also can have significant impacts on ground-water resources. Aquifers in coal areas can include alluvium, overburden, coal seams, and beds underlying coal seams. Removal of the overburden can cause total or partial loss of an aquifer. Underground mining can disrupt flow by cutting through the aquifer. In the instance of surface mining, reclamation may or may not enable the aquifer to reestablish itself. This disruption of the aquifer results in a decline in water levels in the aquifer and in nearby water-supply wells. Conversely, water levels may rise with time in undisturbed areas downdip from the mined area. This may result from increased recharge in the reclaimed mine areas. Once mining activity has stopped, underground mines can fill with ground water and discharge it in new locations.

Disruption of aquifers and related effects due to mining also can affect ground-water quality. Rock material exposed and fragmented by mining is unweathered. As water comes in contact with this material, increases in dissolved solids and trace elements may occur. Ground water may remain in contact with this material for a long time, causing dissolved-solids concentrations to increase significantly. Mining also can cause two or more aquifers that were separated by impermeable layers to become joined. If the water quality between the two differs significantly, the quality in one of the aquifers could be degraded by water flowing from the other.

One of the principal problems associated with underground mines is subsidence. Subsidence is the deformation and settling of the surface and overburden above an area of underground mining. Ground-water aquifers can be damaged by the occur. rence of subsidence and, in some instances, surface-water flow can be altered. Dunrud (1976) discusses causes of subsidence in the Somerset coal field located in Area 58. 

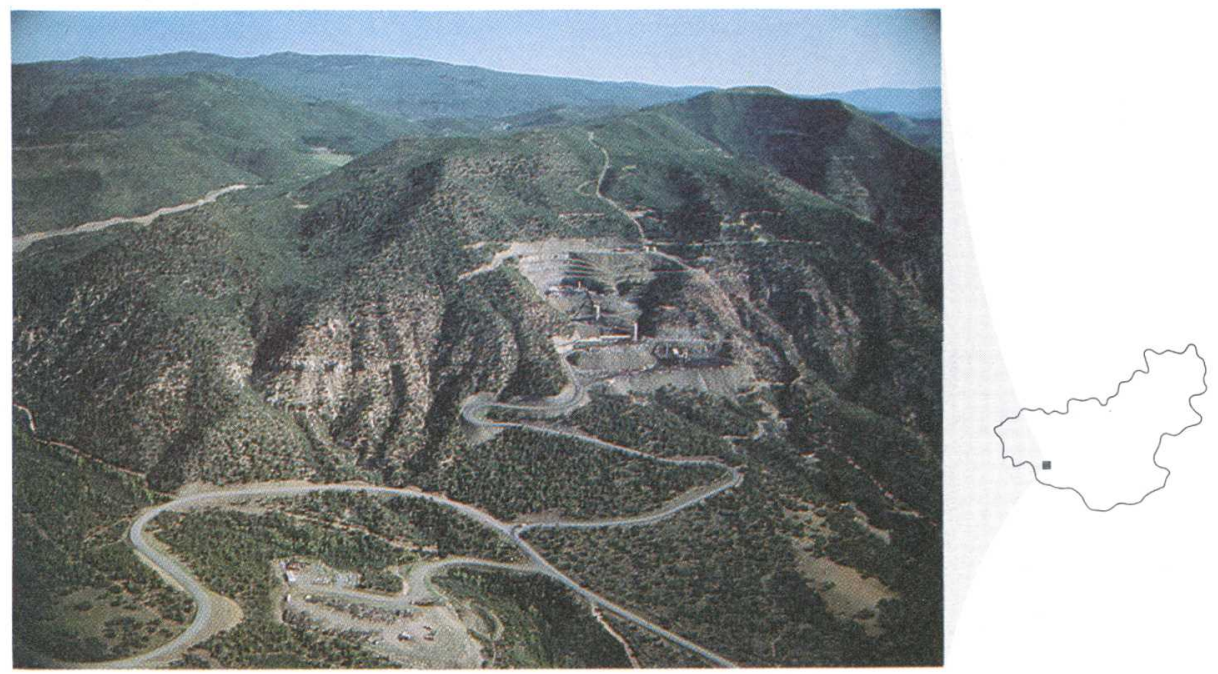

A. Underground mine near Paonia. Part of the hillside has been removed to provide development sites for mine facilities.

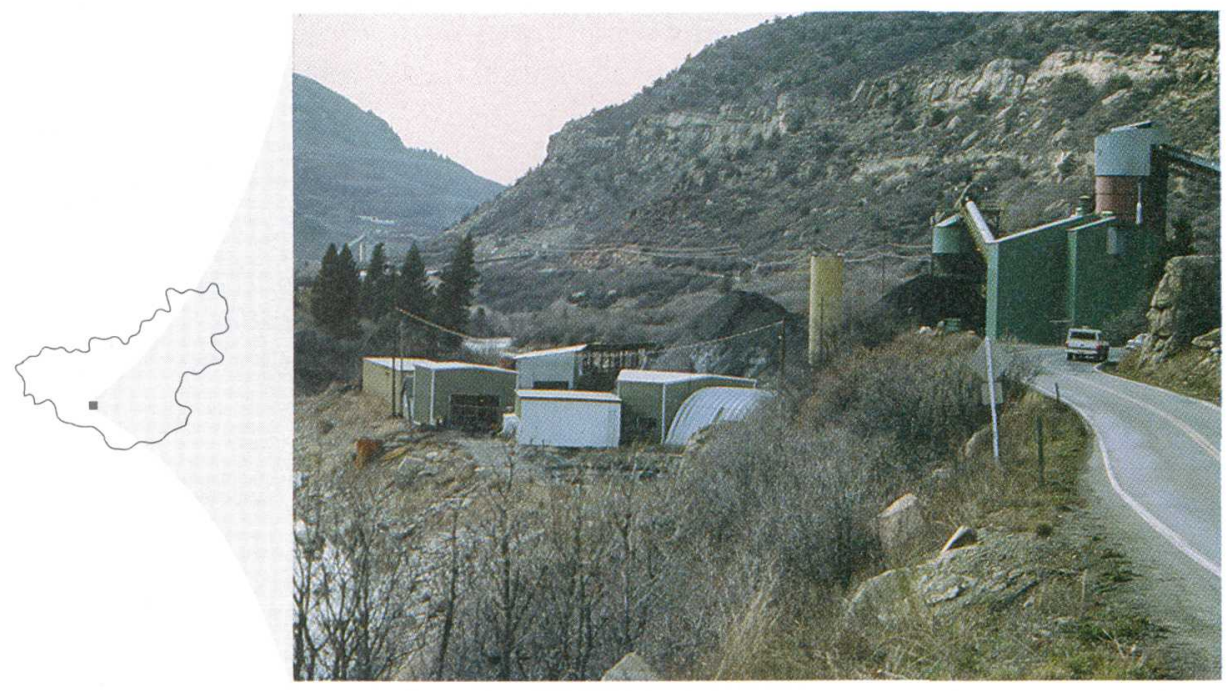

B. Mine tipple and associated structures located at bottom of steep stream valley of the North Fork of the Gunnison River.
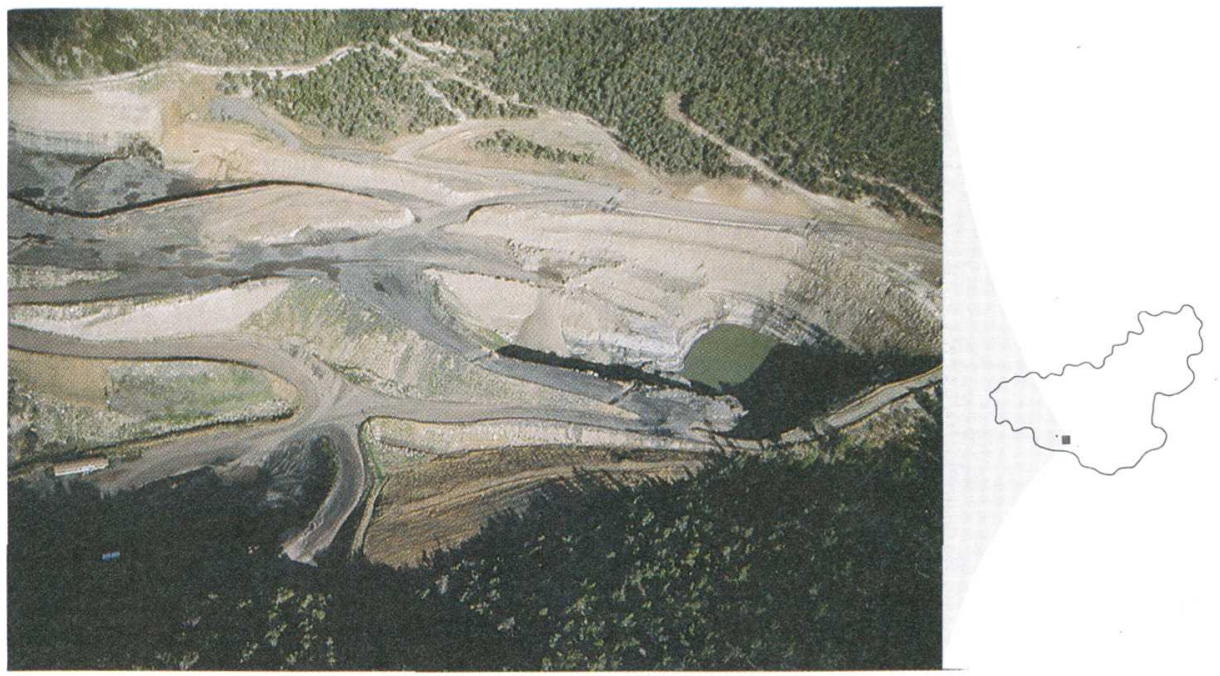

C. Strip mine operating near Cedaredge, Colorado exposes large areas of soil.

Figure 1.3-1 Coal-mining operations in Area 58. 


\subsection{INTRODUCTION--Continued \\ 1.4 Definition of Terms}

\section{Terms Used in Hydrologic Reports Defined}

Technical terms that are used in this hydrologic report are defined.

\begin{abstract}
Alkalinity is a measure of a system's capacity to neutralize acid. Alkalinity principally is due to the presence of carbonate and bicarbonate ions, although other dissolved ions may contribute to it. These two ions primarily are derived from the dissolution of carbonate minerals such as calcite and dolomite.
\end{abstract}

Anion is a negatively charged ion.

Anthracite coal is the highest ranking coal. It contains the most fixed carbon of any rank and the smallest proportion of volatile matter.

Anticline is a fold that is convex upward, and has older rocks toward the center of curvature.

Aquifer is a geologic formation, group of formations, or part of a formation that contains sufficient saturated permeable material to yield significant quantities of water to wells and springs.

Alluvial aquifer is an aquifer located in unconsolidated stream deposits of comparatively recent time.

Base flow (or base runoff) is sustained or fairweather runoff composed entirely of ground-water discharge.

Bituminous coal is a medium- to high-ranking coal characterized by high caloric value. These coals average around 50 to 65 percent fixed carbon and 25 to 40 percent volatile matter. Most coal mined in the United States is bituminous.

Calcareous means containing significant amounts of calcium carbonate.

Cation is a positively charged ion.
Climate year in the U.S. Geological Survey is the 12-month period, April 1 through March 31. The climate year is designated by the calendar year in which it ends and which includes 3 of the 12 months. Thus, the year ending March 31,1981 , is called the "1981 climate year."

Coefficient of determination $\left(\mathrm{r}^{2}\right)$, in linear regression, is the square of the correlation coefficient. The coefficient of determination $\times 100$ provides a measure of the percentage of the variation of the dependent variable explained by variation of the independent variable.

Coke is the solid carbonaceous residue obtained from coals after the removal of volatile matter. Coke is a metallurgical fuel used to reduce metallic oxides to metals.

Conglomerate is a rock consisting of rounded gravel cemented in a matrix of sand or silt.

Cubic foot per second $\left(\mathrm{ft}^{3} / \mathrm{s}\right)$ is the rate of discharge representing a volume of 1 cubic foot passing a given point during 1 second and is equivalent to approximately 7.48 gallons per second, or 448.8 gallons per minute, or 0.02832 cubic meters per second.

Dewatering refers to lowering the water level in an aquifer through artificial discharge or the artificial discharge of water from an aquifer because the aquifer is exposed in a mine pit. Removal of such water from the mine pit also may be termed dewatering.

Discharge is the volume of water (or more broadly, volume of fluid plus suspended sediment) that passes a given point within a given period of time. 
Average discharge is the arithmetic mean of individual discharges during a specific period of time.

Instantaneous discharge is the discharge at a particular instant in time.

Dissolved refers to that material in a representative water sample that passes through a 0.45 -micrometer membrane filter. This may include some very small (colloidal) suspended particles as well as the amount of substance present in true chemical solution. Determinations of "dissolved" constituents are made on subsamples of the filtrate.

Dissolved oxygen $(D O)$ is the oxygen content of water in equilibrium with air and is a function of atmospheric pressure and temperature and dissolved-solids concentration of the water. The solubility of dissolved oxygen in water decreases as dissolved solids or temperature increase or as atmospheric pressure decreases.

Dissolved solids is a measure of all dissolved constituents in water. The major ions involved are the cations calcium, sodium, magnesium, and potassium, and the anions bicarbonate, sulfate, and chloride.

Drainage area of a stream at a specific location is that area, measured in a horizontal plane, enclosed by a topographic divide from which direct surface runoff from precipitation normally drains by gravity into the stream above the specified point. Figures of drainage area given herein include all closed basins, or noncontributing areas, within the area unless otherwise noted.

Drainage basin is a part of the surface of the Earth that is occupied by a drainage system, which consists of a surface stream or a body of impounded surface water together with all tributary surface streams and bodies of impounded surface water.

Ephemeral stream is one that flows only in direct response to precipitation and whose channel is at all times above the water table.

Evapotranspiration is the water withdrawn from a land area by evaporation from water surfaces and moist soil and by plant transpiration; the loss of water from leaf and stem tissues of growing vegetation.
Flood-flow frequency curve is a graph showing the magnitude and frequency of flood flows. Frequency herein is expressed as the average interval, in years, between recurrences of an annual maximum flow equal to or greater than that shown by the magnitude scale.

Gaging station is a particular site on a stream, canal, lake, or reservoir where systematic observations of hydrologic data are obtained. When used in connection with a discharge record, the term is applied only to those gaging stations where a continuous record of discharge is computed.

Hogback is a long, sharp-crested ridge carved by differential erosion from a steeply dipping layer or series of layers of resistant rocks.

Hydrograph is a graph showing discharge, water level, or other characteristics of a flowing stream with respect to time.

Hydrologic unit is a geographic area representing part or all of a surface drainage basin or distinct hydrologic feature as delineated by the Office of Water Data Coordination on the State Hydrologic Unit Maps; each hydrologic unit is identified by an eight-digit number.

Igneous rock is one that formed by solidification from molten or partially molten materials.

Ion is an atom, group of atoms, or molecule that has acquired a net electrical charge.

Lithology is the physical character of a rock, generally determined by observation with the unaided eye or with the aid of a low-power magnifier.

Load is the amount of material, whether dissolved, suspended, or on the bed, which is moved and transported by a flowing stream.

Low-flow frequency curve is a graph showing the magnitude and frequency of minimum flows for a period of given length. Frequency usually is expressed as the average interval, in years, between recurrences of an annual minimum flow equal to or less than that shown by the magnitude scale.

Metamorphic rock is a rock that has been altered in composition, texture, or internal structure in response to pronounced changes of temper- 
ature, pressure, and chemical environment.

Microgram per liter $(\mu \mathrm{g} / L)$ is a unit expressing the concentration of chemical constituents in solution as mass (micrograms) of solute per unit volume (liter) of water. One thousand micrograms per liter is equivalent to one milligram per liter.

Micromho ( $\mu m h o)$ is one-millionth of a mho, which is the practical unit of specific conductance equal to the reciprocal of the ohm.

Milligrams per liter $(m g / L)$ is a unit for expressing the concentration of chemical constituents in solution. Milligrams per liter represent the mass of solute per unit volume (liter) of water. Concentration of suspended sediment also is expressed in $\mathrm{mg} / \mathrm{L}$, and is based on the mass of sediment per liter of water-sediment mixture.

Moles per liter is a unit expressing the concentration of chemical constituents in solution. A mole is a mass, expressed in grams, equivalent to the molecular weight.

Oil shale is shale containing such a proportion of hydrocarbons as to be capable of yielding mineral oil on slow distillation.

Orogeny is the process of mountain formation.

Oxidation is the process in which oxygen is added to a substance, hydrogen is lost from a compound, or an element loses electrons.

Partial-record station is a particular site where limited streamflow or water-quality data are collected systematically over a period of years for use in hydrologic analyses.

Perennial stream is one that flows continuously.

Permeability is the property or state of enabling gases or fluids to pass through.

$p H$ of water is a measure of the hydrogen-ion concentration in the water, but the concentration of hydrogen ions is so small that it cannot easily be expressed as milligrams per liter. As a result, $\mathrm{pH}$ is defined as the negative base- 10 logarithm of the hydrogen-ion concentration in moles per liter. $\mathrm{A} \mathrm{pH}$ of 7.0 is neutral. Values less than 7.0 indicate acid conditions, and values greater than 7.0 indicate basic conditions.
Proximate analysis is, in the case of coal and coke, the determination, by prescribed methods, of moisture, volatile matter, fixed carbon (by difference), and ash.

Rank is a way of classifying coal, based on the relative proportions of fixed carbon, volatile matter, moisture, Btu value, and ash. Coals vary in rank from lignites to anthracites, the latter having the highest proportions of carbon and usually ash and the lowest proportions of moisture and volatile material.

Recharge is the process by which water is added to the zone of saturation (an aquifer), either directly into a formation or indirectly by way of another formation. Recharge is also the quantity of water that is added to the zone of saturation.

Recurrence interval is (1) The average time interval between actual occurrences of a hydrologic event of a given or greater magnitude; (2) in an annual flood series, the average interval in which a flood of a given size recurs as an annual maximum; and (3) in partial duration series, the average interval between floods of a given size, regardless of their relationship to the year or any other period of time.

Runoff is that part of the precipitation that appears in surface streams.

Sediment is solid material that originates mostly from disintegrated rocks and is transported by, suspended in, or deposited from water; it includes chemical and biochemical precipitates and decomposed organic material, such as humus. The quantity, characteristics, and cause of the occurrence of sediment in streams are affected by environmental factors. Some major factors are degree of slope, length of slope, soil characteristics, land use, and quantity and intensity of precipitation.

Suspended sediment is the sediment that at any given time is maintained in suspension by the upward components of turbulent currents, or that exists in suspension as a colloid.

Suspended-sediment concentration is the concentration of suspended sediment in the sampled zone (from the water surface to a point approximately 0.3 foot above the bed) expressed as milligrams of dry sediments per liter of watersediment mixture $(\mathrm{mg} / \mathrm{L})$. 
Sedimentary rock is a rock formed by the accumulation of sediment in water or from the air. The sediment may consist of rock fragments of various sizes, of the remains or products of animals and plants, of the product of chemical action or evaporation, or a mixture of these materials.

Solute is any substance derived from the atmosphere, vegetation, soil, or rocks and is dissolved in water.

Specific conductance is a measure of the ability of a water to conduct an electrical current. It is expressed in micromhos per centimeter at $25^{\circ}$ C. Specific conductance is related to the number and specific chemical types of ions in solution and can be used for approximating the dissolved-solids content in the water. Commonly, the concentration of dissolved solids (in milligrams per liter) is about 65 percent of the specific conductance (in micromhos). This relation is not constant from stream to stream or from well to well, and it may vary in the same source with changes in the composition of the water.

Standard error of estimate in linear regression is the standard deviation of the residuals. A residual is the difference between the actual value and the value predicted from the regression equation. Standard error of estimate has the same units as the dependent variable and indicates how reliably it may be estimated from a given value of the independent variable.

Streamflow is the discharge that occurs in a natural channel. Although the term "discharge" can be applied to the flow of a canal, the word "streamflow" uniquely describes the discharge in a surface stream course. The term "streamflow" is more general than "runoff" as streamflow may be applied to discharge whether or not it is affected by diversion or regulation.

Streamflow-duration curve is a cumulativefrequency curve showing the percent of time that specified streamflows were equaled or exceeded during a given period. The flow-duration curve does not show the chronological sequence of flows and applies only to the time period for which it is developed.

Structural basin is a roughly circular geologic structure in which the rock strata are inclined toward a central point.
Subbituminous coal is the broad rank of coal below bituminous. It contains 10 to 70 percent volatile matter and 20 to 80 percent fixed carbon.

Syncline is a fold that is convex downward, and has younger rocks toward the center of curvature.

Tectonic activity (tectonism) is any form of instability in or deformation of the Earth's crust.

Total recoverable is the amount of a given constituent present after a representative watersuspended sediment sample has been digested by a method (usually using a dilute acid solution) that results in dissolution of only readily soluble substances. Complete dissolution of all particulate matter is not achieved by the digestion treatment; and thus the determination represents something less than the "total" amount (that is, less than 95 percent) of the constituent present in the dissolved and suspended phases of the sample. To achieve comparability of analytical data, equivalent digestion procedures would be needed for all laboratories performing such analyses, because different digestion procedures are likely to produce different analytical results.

Trace element is any constituent of water that generally occurs in concentrations of less than 1 milligram per liter. However, some trace elements may at times exceed this concentration.

Ultimate analysis is, in the instance of coal and coke, the determination of carbon and hydrogen in the material, as found in the gaseous products of its complete combustion, the determination of sulfur, nitrogen, and ash in the material as a whole, and the estimation of oxygen by difference.

Volatile matter is composed of carbohydrates, resins, exines, and other constituents found in coal that readily evaporate at low temperatures. In coking, destructive distillation drives off nearly all volatile materials, leaving a highly carbonaceous fuel.

Water year in the U.S. Geological Survey is the 12-month period, October 1 through September 30. The water year is designated by the calendar year in which it ends and which includes 9 of the 12 months. Thus, the year ending September 30, 1981, is called the "1981 water year." 


\title{
2.0 PHYSICAL FEATURES 2.1 Climate
}

\section{Climate Varies Greatly Within Short Distances}

\author{
Most of the study area is semiarid with alpine \\ conditions prevailing in the eastern parts.
}

The wide variation in elevations from west to east within the study area strongly affects the climatic conditions found at a given location. For every 1,000-foot increase in elevation, an air-temperature decrease of $5.4^{\circ}$ Fahrenheit can be expected. Mean annual temperatures range from a low of $32.8^{\circ}$ Fahrenheit at Taylor Park near the Continental Divide to a high of $54.1^{\circ}$ Fahrenheit at Palisade in the Grand Valley. Because of the dominating effect of elevation, the daily, monthly, and annual average temperatures are highest at the lower elevations to the west. However; normal night-time temperatures in these basins can be less than those of the mountains due to cold air draining from the mountains and settling in the valleys.

Average monthly temperatures for several representative locations are shown in figure 2.1-1. Aspen and Crested Butte both represent mountain areas, while Grand Junction and Glenwood Springs are more typical of the plateau areas. Average high temperatures occur during July at all locations. There is approximately a $20^{\circ} \mathrm{Fahrenheit}$ difference between the average high at Grand Junction and the average high at Crested Butte, reflecting the differences in elevation. The coldest winter temperatures at all locations generally occur during January.

The length of the growing season also varies with elevation. Crested Butte, located at 8,855 feet above sea level, has an average of only 29 days between the last spring frost and first fall frost. However, Grand Junction, located at 4,849 feet above sea level, has a growing season of 185 days.

The topography of an area can modify the effect of elevation. If cold air frequently drains into a valley, then the growing season for the lower elevation location can be shortened. For instance, Gunnison, located in a valley at 7,664 feet above sea level, has an average frost-free season of 45 days while Aspen, at 7,928 feet, has a frostfree season of 76 days. In general, locations in the Grand Valley to the west have the longest growing season.

The precipitation totals for the majority of the study area are less than 40 inches per year. Precipitation is brought to the region by Pacific air masses moving in from the west. These air masses have a relatively small moisture content when they reach Colorado because of the removal of moisture as the air moves up and over the mountains to the west. As the air rises over the mountains, it cools, decreasing its ability to hold moisture.

This process also affects the annual precipitation totals within the study area. The areal variation in annual precipitation totals for Area 58 is shown in figure 2.1-2. The smallest amounts (less than 10 inches per year) occur in the plateau region to the west. As the air masses move over the mountains to the east, precipitation totals, including snow, increase to more than 40 inches per year.

The seasonal distribution of precipitation throughout the year also varies with location. Average monthly precipitation for four locations in the study area are shown in figure 2.1-3. Mountain locations, such as Crested Butte, receive most of their precipitation in the winter months in the form of snow. Crested Butte receives an average of 216 inches of snow per year. The resulting accumulation of snow in the mountains is the principal source of streamflow in the region when it melts in the spring. The precipitation pattern for Grand Junction is more typical of arid and semiarid locations where the largest average precipitation total occurs during August. This is the result of convectional storms when air heated during the day cools rapidly during the afternoon resulting in thunderstorms. Because of the small amount of rainfall in the plateau areas, irrigation is necessary to grow crops in much of the area. Droughts, where 75 percent or less of the normal annual precipitation occurs, can be expected 1 year in every 7 years (U.S. Bureau of Land Management, 1979).

Detailed information about precipitation frequencies can be found in the U.S. National Oceanic and Atmospheric Administration Atlas 2, "PrecipitationFrequency Atlas of the Western United States" (Miller and others, 1973). Daily precipitation and temperature data are published monthly as "Climatological Data for Colorado" by the U.S. National Oceanic and Atmospheric Administration, National Climate Center, Asheville, N.C. Also available is "Climates of the States" (U.S. National Oceanic and Atmospheric Administration, 1980), which presents summaries, averages, and extremes of climatic data at selected stations as well as a narrative of each State's climate. 


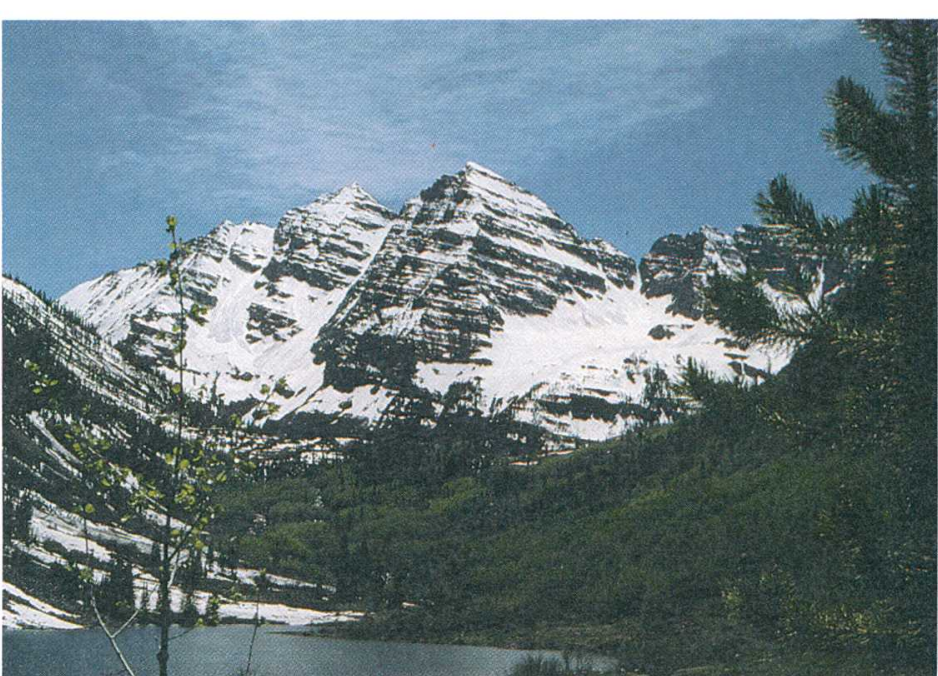

The melting of the mountain snowpack provides much
of the surface water for Area 58 .

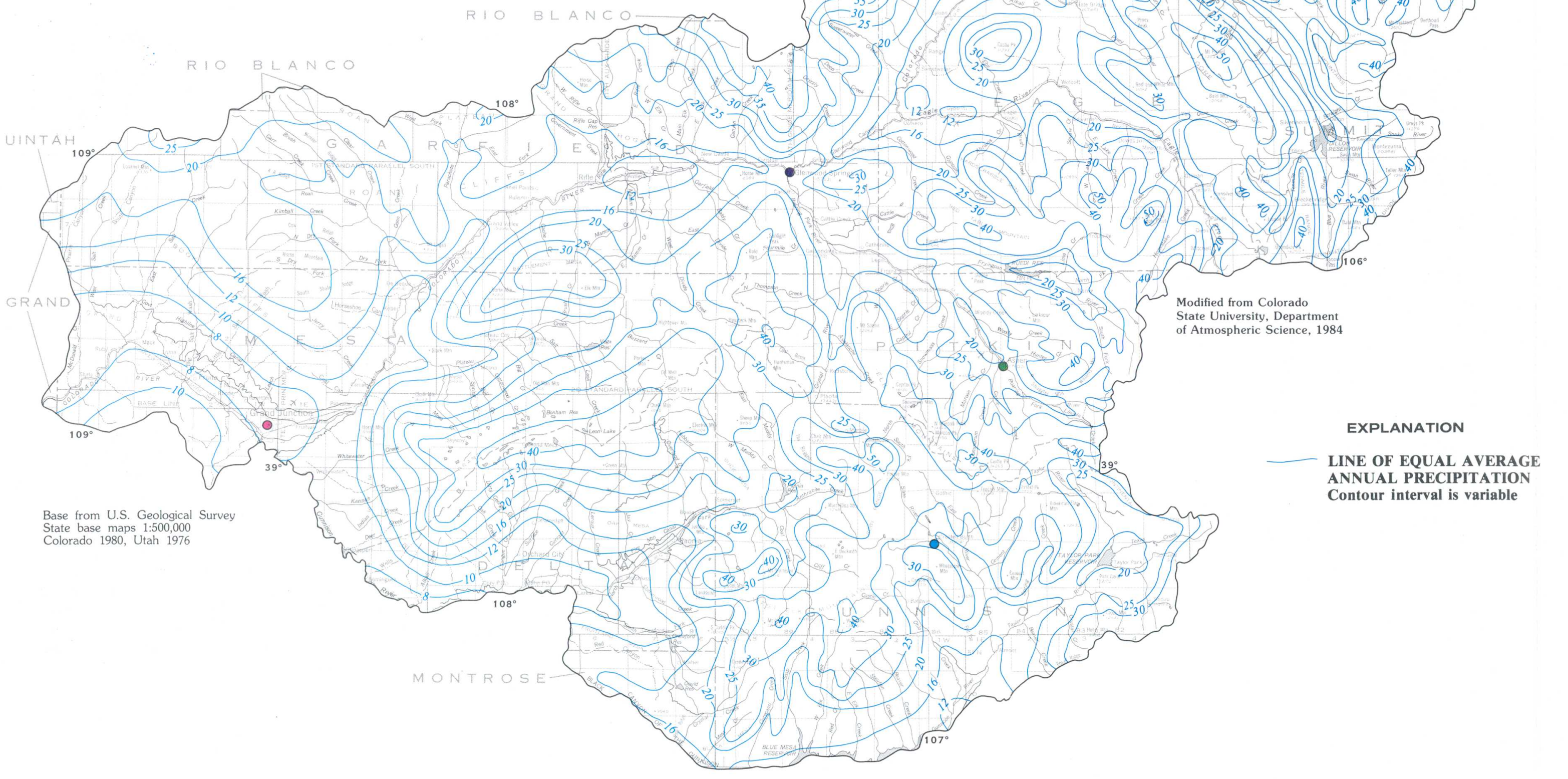

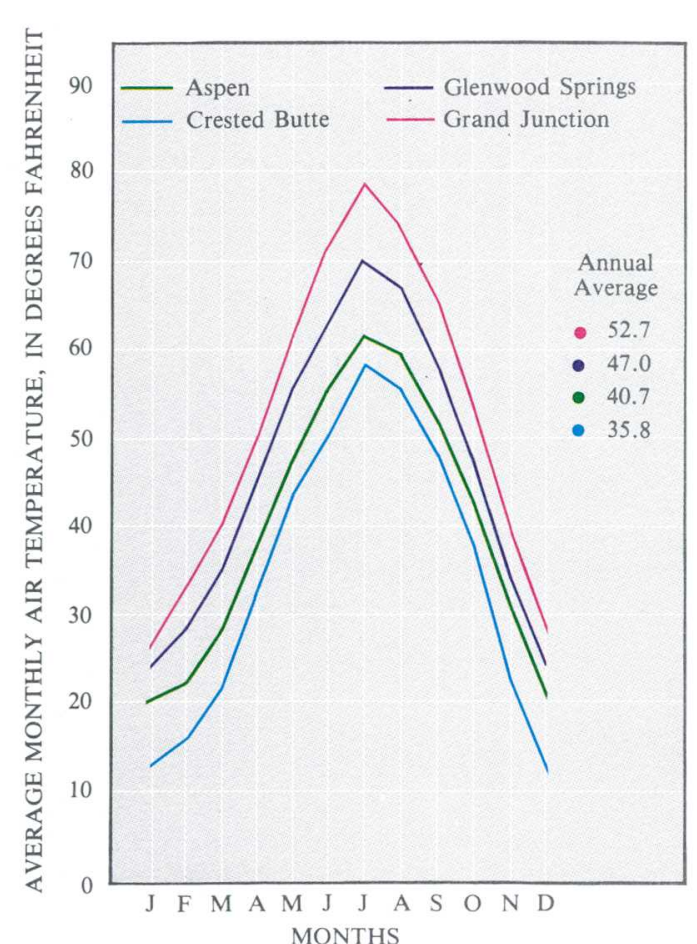

Figure 2.1-1 Seasonal variation of average monthly air temperatures at Aspen,
Crested Butte, Glenwood Springs,

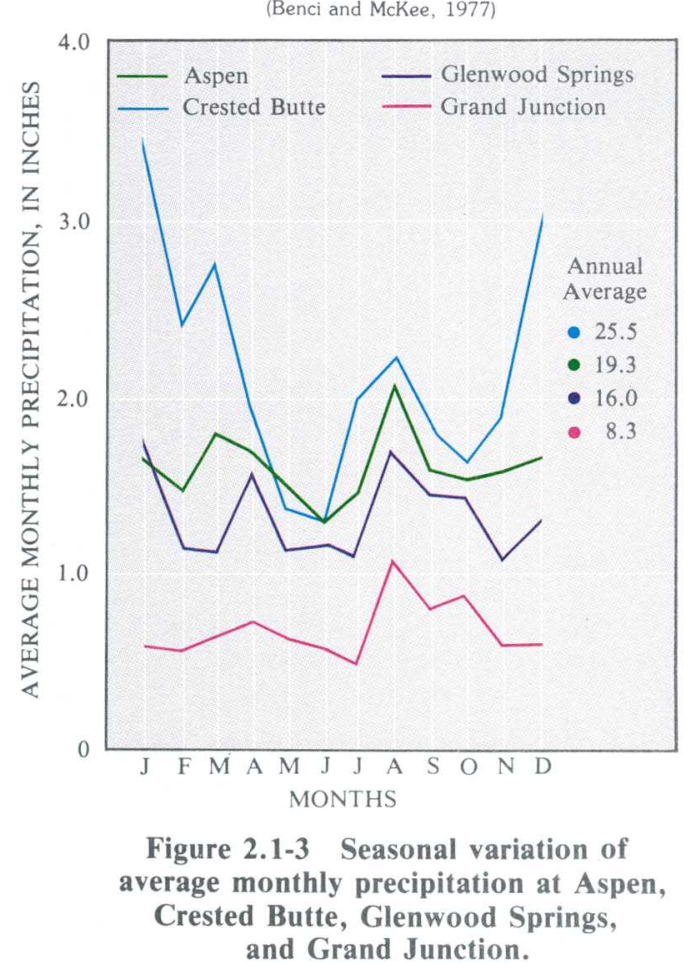




\title{
2.0 PHYSICAL FEATURES--Continued 2.2 Geology
}

\section{Bedrock Formations Range from Precambrian to Quaternary Age}

\author{
The principal coal-bearing formations are the Mount Garfield, Iles, \\ Williams Fork Formations of the Mesaverde Group \\ of the Cretaceous Period.
}

Area 58 is underlain by rocks ranging in age from Precambrian (1,800 million years) to Quaternary. The long history of sedimentation, erosion, and tectonic activity associated with the formation of these rocks has resulted in a complex geologic setting. The geologic formations cropping out in the region are shown in generalized form in figure 2.2-1. The principal coalbearing formations are shown individually on the map (Mount Garfield, Iles, and Williams Fork Formations of the Mesaverde Group) as is the oil-shale-producing formation (Green River Formation). The remaining formations are grouped by geologic age. Regional geologic maps of the study area have been prepared by Cashion (1973: Grand Junction Quadrangle), Tweto, and others (1978: Leadville Quadrangle), and Tweto, and others (1976: Montrose Quadrangle).

The coal-bearing formations all were formed during the Late Cretaceous Epoch and are found in the western part of the region. The rock sequences of the Cretaceous Period indicate a series of marine and nonmarine cycles of sedimentation resulting in formations composed principally of shale, sandstone, and coal members. The Mount Garfield, Iles, and Williams Fork Formations, and the Mesaverde Group contain the principal economic coal deposits in the area. They are mapped individually in figure 2.2-1 or as the Mesaverde Group when undifferentiated. Collins (1976) provides a review of the previous work on these formations and presents a detailed discussion of their lithology and stratigraphy. This Mesaverde Group is primarily nonmarine in origin and is bounded above and below by marine shales (Mancos and Lewis Shales). Thicknesses of the Mesaverde Group vary from about 4,500 feet to more than 6,000 feet (Collins, 1976). Sediments composing the various formations represent a variety of coastal environments and include marine shales and siltstones, delta and beach siltstones and sandstones, brackish water siltstones, mudstones, claystones, shales, coal beds, and rarely algal limestones (Collins, 1976).
The Laramide Orogeny, a long series of mountainbuilding events, began during the Late Cretaceous Epoch when the coal-bearing formations were being deposited and continued into the Tertiary Period. An intense period of volcanic activity occurred during the orogeny, resulting in a number of igneous structures in the area. The heat from these structures affected the coal-bearing formations. In Gunnison and Pitkin Counties, coals were increased from bituminous to anthracite rank by the heat. The igneous intrusions also are associated with the formation of the Colorado mineral belt that touches the eastern part of the study area near Aspen and Crested Butte.

Precambrian formations are the oldest rocks in the region and consist of gneisses, schists, and granites that outcrop in the mountains along the eastern and northern boundaries of the area. These igneous and metamorphic rocks are very resistant to erosion and form the core of these mountains. The mountains are folded anticlines, and numerous faults are found throughout them. The oldest of the Precambrian formations are dated between 1,700 and 1,800 million years making them among the oldest rocks known (Tweto, 1980b).

Following Precambrian time, the formations representing the Paleozoic and Mesozoic Eras were deposited. Lower Paleozoic sedimentary rocks present in the area principally are marine deposits. Near the end of the Paleozoic Era, a series of tectonic events occurred resulting in the formation of the ancestral Rocky Mountains. The sedimentary rocks of the late Paleozoic and early Mesozoic Eras indicate a long erosional sequence in which the ancestral Rocky Mountains were eroded (Maughan, 1980). By the middle of the Mesozoic, seas once again had flooded the region beginning a new period of marine deposition that overlapped into the Cretaceous Period (Berman and others, 1980). 


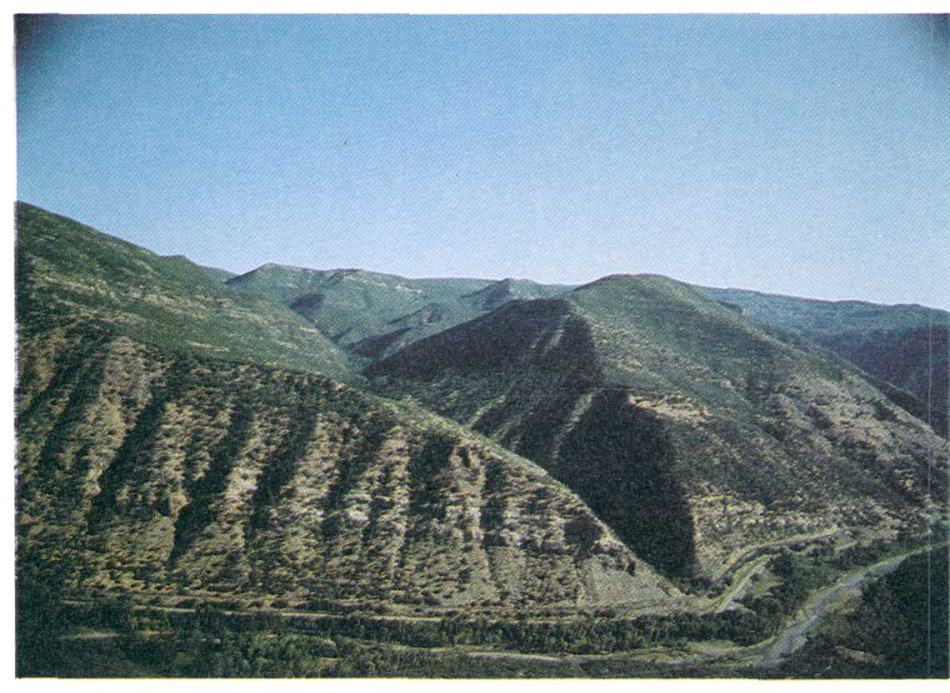

Outcrop of Mesaverde Group along the North Fork of
the Gunnison; principal coal-bearing formation in Area 5

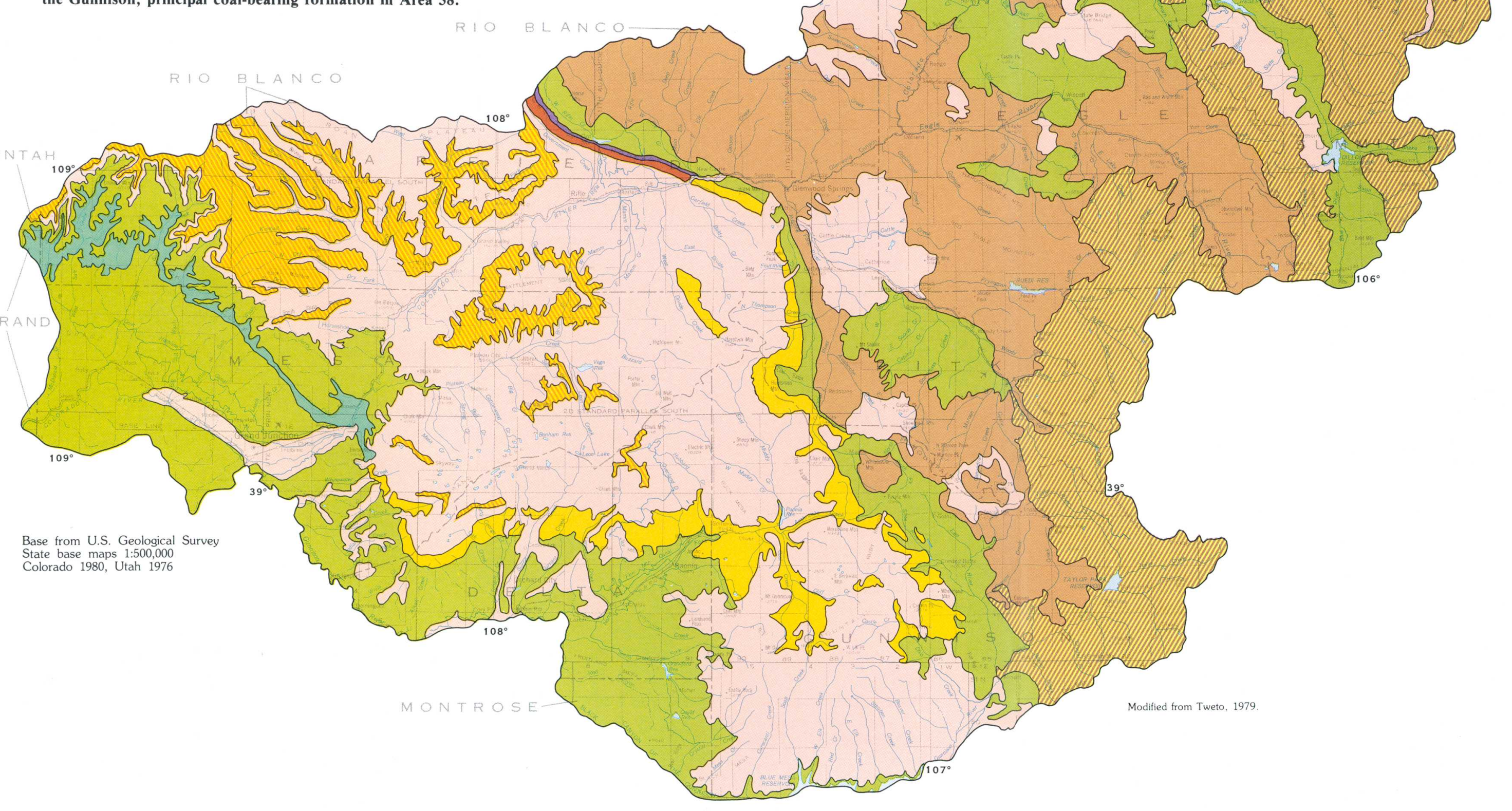

Figure 2.2-1 General geology
EXPLANATION

$\square$ QUATERNARY and TERTIARY - Modern alluvium and gravel, glacial
drift of Pindale, Bull Lake and pre-Bull Lake age land slide deposits, basalt flows (1.8 m.y.), ancient alluvium
Browns Park Formation, Troublesome Formation, Uint Formation, Wasatch Formation, Ohio Creek Formation, Dry Union Formation
mation, basalt flows and associarted tuff, breccia. conglomer

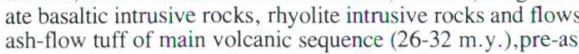

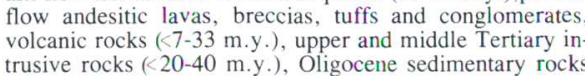

GREEN RIVER FORMATION (TERTIARY)
sandstone and kerogen oil shale

*MESAVERDE GROUP (CRETACEOUS)- Sandstone, siltstone, mudstone
claystone, shale and coal beds: marine to nonmarine

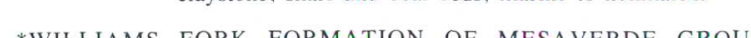

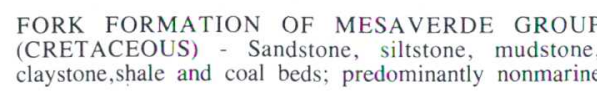

*ILES FORMATION OF MESAERRDE GROUP (CRETACEOUS) -
Sandstone, siltstone, mudstone, shale and coal bedss; pre-
dominantly marine

*MOUNT GARFIED FORMATION AND SEGO SANDSTONB
(CRETACEOUS) - Sandstone, shale and coal beds

MESOZOIC - Laramide intrusive rocks (40-72? m.y.), Windy Gap Member
of Middle Park Formation, Hunter Canyon F F Frratior Group, (Including Nobrara Formation and other units.s.

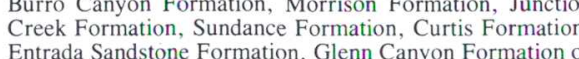

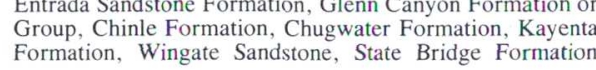

PALEOZOIC -

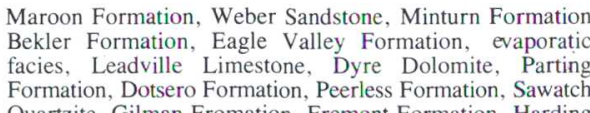

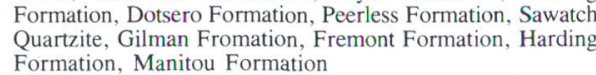

IIIIS

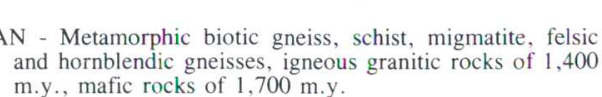

\section{* Coal-bearing formation}

EXPLANATION

m.y. - million years
$<<$ - less than 


\title{
2.0 PHYSICAL FEATURES--Continued 2.3 Physiography
}

\section{Colorado Plateau and Southern Rocky Mountains are the Principal Physiographic Provinces}

\author{
The area is characterized by a rugged landscape \\ with high mountains and steep slopes.
}

The study area is almost equally divided between the Southern Rocky Mountain province to the northeast and the Colorado Plateau province to the southwest (fig. 2.3-1). A small finger of the Wyoming Basin province extends into the northcentral part of the area. The topography is greatly varied with elevations ranging from approximately 4,300 feet at the Colorado-Utah State line to more than 14,200 feet at Gray's Peak along the Continental Divide near Loveland Pass. The Continental Divide forms the eastern boundary of the study area. The boundary for the entire area is the hydrologic boundary for the upper Colorado River drainage area and the area north of the Gunnison River.

A complex series of tectonic and erosional events is responsible for the present physiographic setting of the region. Although these events began approximately 1,700 million years ago, events beginning during the Cretaceous Period (approximately 65 to 138 million years ago) created most of the land forms present today. During most of the Cretaceous Period, the region was covered by the ocean. Toward the end of the Cretaceous Period, this sea regressed, and a long series of mountainbuilding events, termed the Laramide Orogeny, began. The result of this uplifting was the formation of the Rocky Mountains. The Laramide Orogeny extended over a 20 million-year period. The mountains formed by this orogeny are broad anticlinal arches and in Area 58 are represented by the Gore, Sawatch, and Elk Mountain Ranges of the Southern Rocky Mountain province. These uplifts occurred by both folding and faulting.

The Colorado Plateau province to the west was not affected by most of the tectonic disturbances during the Laramide Orogeny. As a result, the
Plateau province is distinguished by nearly horizontal rock deposits as seen along Battlement Mesa and by canyons as seen surrounding Plateau Creek. Subsidence associated with the Laramide Orogeny did result in the formation of structural basins such as the Piceance basin. This basin is the eastern extension of the Uinta Basin that continues westward into Utah.

The Laramide Orogeny was followed by a long erosional period. During this period, volcanic activity occurred that covered large areas with volcanic deposits and a number of dikes, sills, and laccoliths such as the West Elk Mountains. A final tectonic event occurred during Miocene and Pliocene time, which uplifted a large region encompassing all of Colorado and several adjacent states. This uplift raised these areas another 5,000 feet, rejuvenating the area's streams and rivers and increasing their erosional force. The Cretaceous sedimentary rocks overlying the mountains were eroded away, exposing the more resistant Precambrian rocks seen today. Finally, during Pleistocene time, glaciers further shaped the peaks, widened the valleys, and left extensive deposits of alluvium as they melted.

The result of those geologic processes is a rugged landscape with north-northwest trending mountain ranges in the east ranging from 11,000 to more than 14,000 feet in height. The mountains are flanked by steeply dipping sedimentary rocks. To the west are high plateaus bordered by steep cliffs along the valleys. Distinctive mesas are conspicuous features in the area. Discussion in this section of the report is based on Fenneman (1931), Thornbury (1965), and Tweto (1977 and 1980a). 
SIOGRAPHIC PROVINCES

Colorado Plateau

$\square$ Southern Rocky Mountains

Wyoming Basin

- Approximate division between physiographic provinces
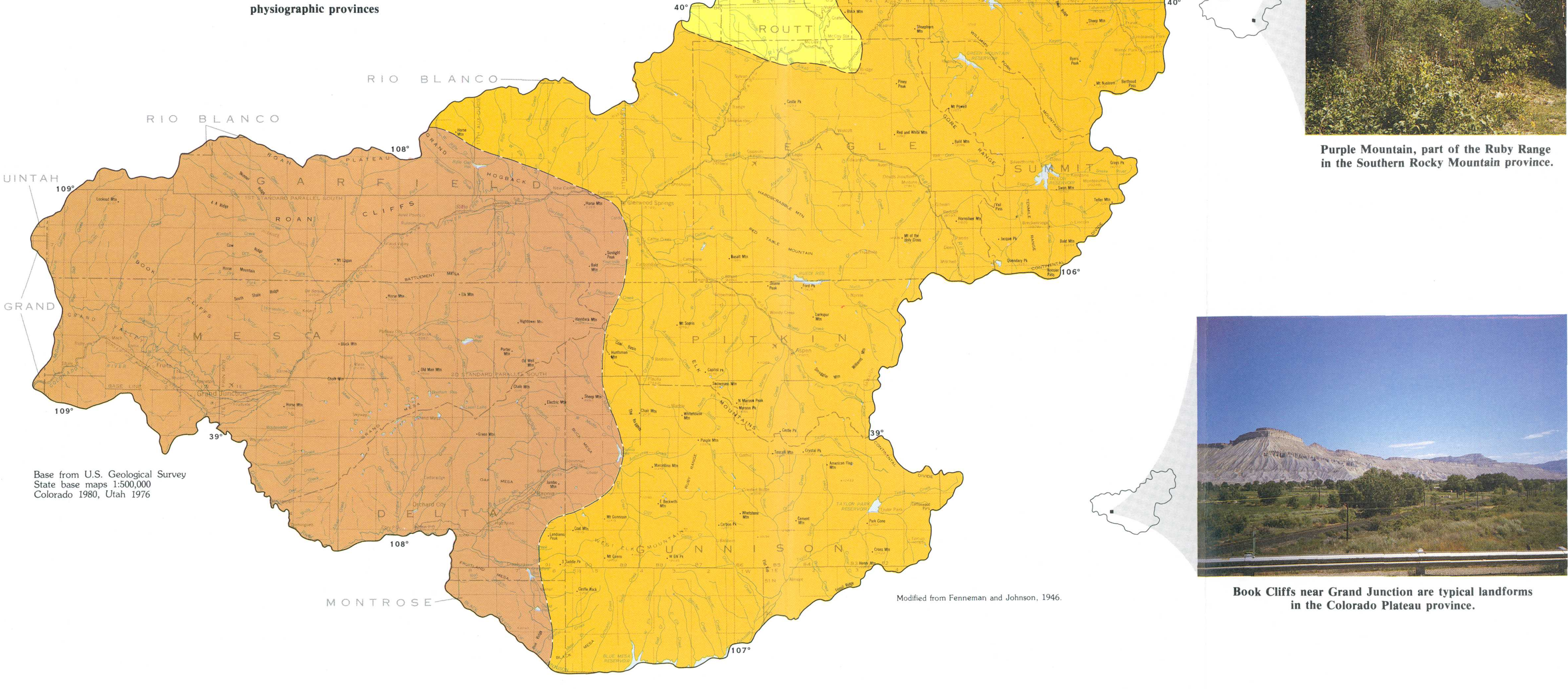

Book Cliffs near Grand Junction are typical landforms the Colorado Plateau province. 


\subsection{PHYSICAL FEATURES--Continued 2.4 Drainage}

\section{Colorado River Originates in the Study Area}

Drainage area includes the headwaters of the Colorado and its tributaries.

The Colorado River is the principal stream draining Area 58. Approximately 13,132 square miles are included within the study area boundaries. In this area, 9,828 square miles drain into the Colorado River above its confluence with the Gunnison River, and 3,304 square miles are within the Gunnison River drainage. The Gunnison River joins the Colorado River at Grand Junction. Other principal tributaries to the Colorado River are the Eagle, Roaring Fork, Williams Fork, Fraser, and Blue Rivers.

Drainage to the Colorado River is skewed because all the principal tributaries enter from the south (fig. 2.4-1). It is believed that the ancient Colorado River (early Tertiary Period) flowed west to the Uinta Basin where the White River now flows. The river's course was probably east of what is now the Gore Range. Approximately 10 million years ago during the Miocene Epoch, a series of uplifts began causing this upper area to drain southward as it does now. As the river moved south, these uplifts also created the Gore Range through which the Colorado River cut its present path. The profile of the Colorado River from its origin to below Glenwood Springs is shown in figure 2.4-2. A pronounced decrease in elevation occurs as the river passes the Gore Range, showing its effect on the river. The Colorado River then receives the flow of the Eagle River above Glenwood Canyon. The valleys of the Colorado, Eagle, and Roaring Fork Rivers are about 3,000 to 4,000 feet deep. Most of this depth was cut during the Pliocene. Later, as the land was uplifted, these rivers maintained their courses by cutting through the rock as it rose and during a period of about 10 million years produced these valleys. Additional downcutting occurred as the glaciers melted at the end of the Pleistocene Ice Age (10,000 years ago) (Hunt, 1969).

The southern boundary of the study area follows the main stem of the Gunnison River. The course of the Gunnison, from its headwaters west to Grand Mesa, is much older than that of the Colorado and may date to the end of the Eocene Epoch 38 million years ago. The Black Canyon of the Gunnison, however, was not formed until the uplifting began during Pliocene time. The canyon is now about 2,500 feet deep. The upper part of the river has a relatively low gradient dropping only about 15 feet per mile. However, along the canyon the gradient more than doubles and at some points is as much as 100 feet per mile (Hansen, 1965).

Hydrologic units for Area 58 are shown in figure 2.4-1. Each hydrologic unit or drainage area has been assigned a unique number, and these numbers are part of a national numbering system. The first two digits identify the region, in this instance, Region 14-Upper Colorado Region. Two subregions are found in the study area: 1401-Colorado Headwaters and 1402-The Gunnison. The remaining digits are used to further subdivide the drainage areas into accounting units and the smallest division, cataloging units. This system provides a consistent set of boundaries, codes, and names for drainage areas throughout the United States and the Caribbean outlying areas that can be used for retrieval of water data (U.S. Geological Survey, 1982). 


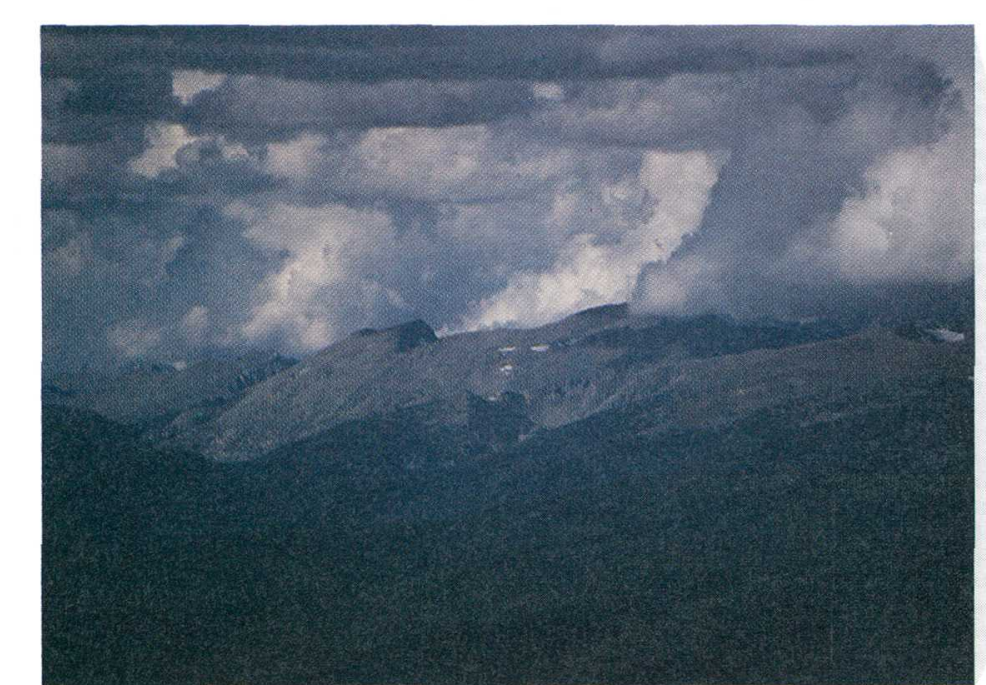
The Continental Divide in Rocky Mountain National Park
forms the headwaters of the Colorado River.

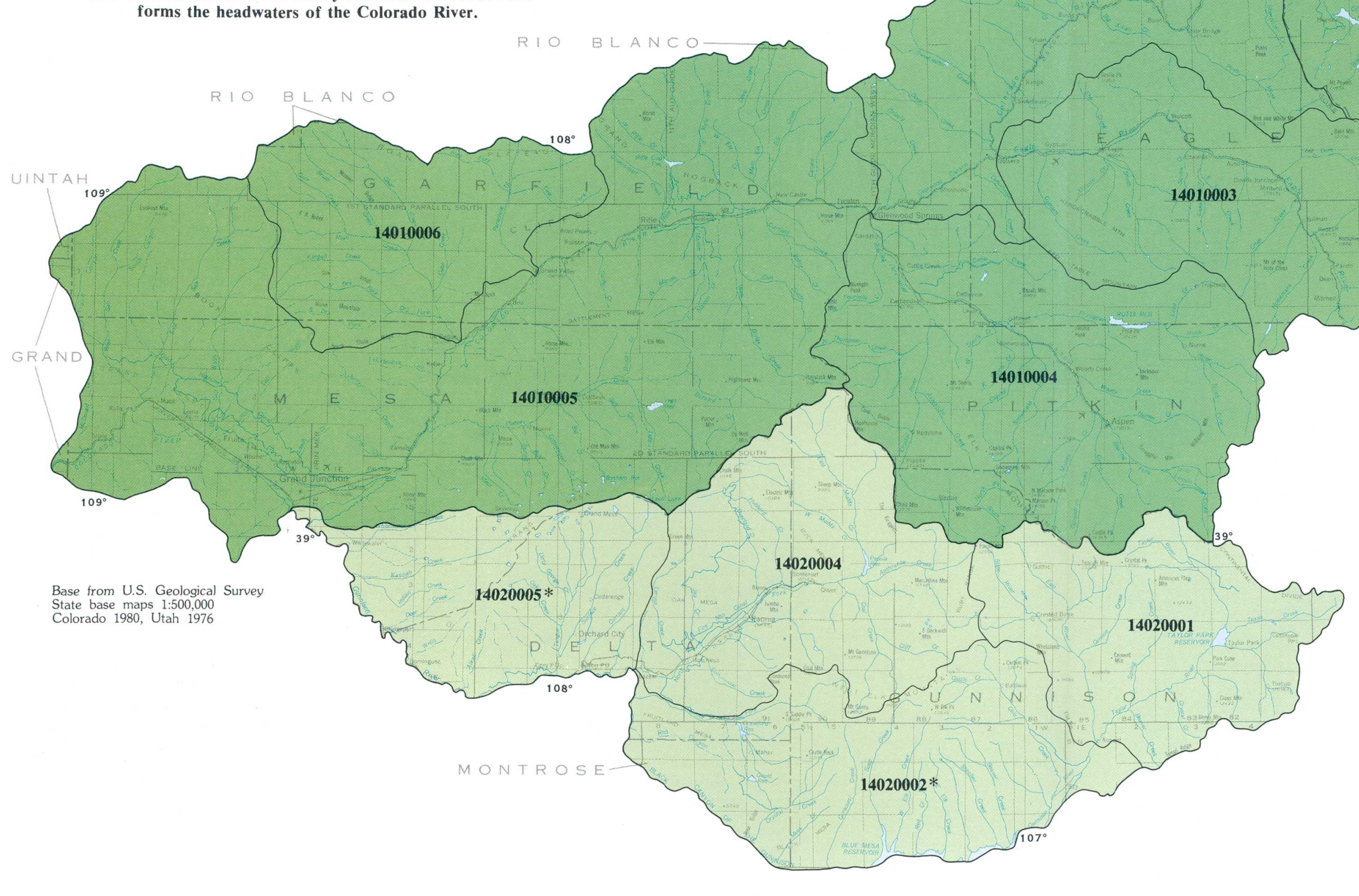

Figure 2.4-1 Drainage boundaries and hydrologic unit divisions.

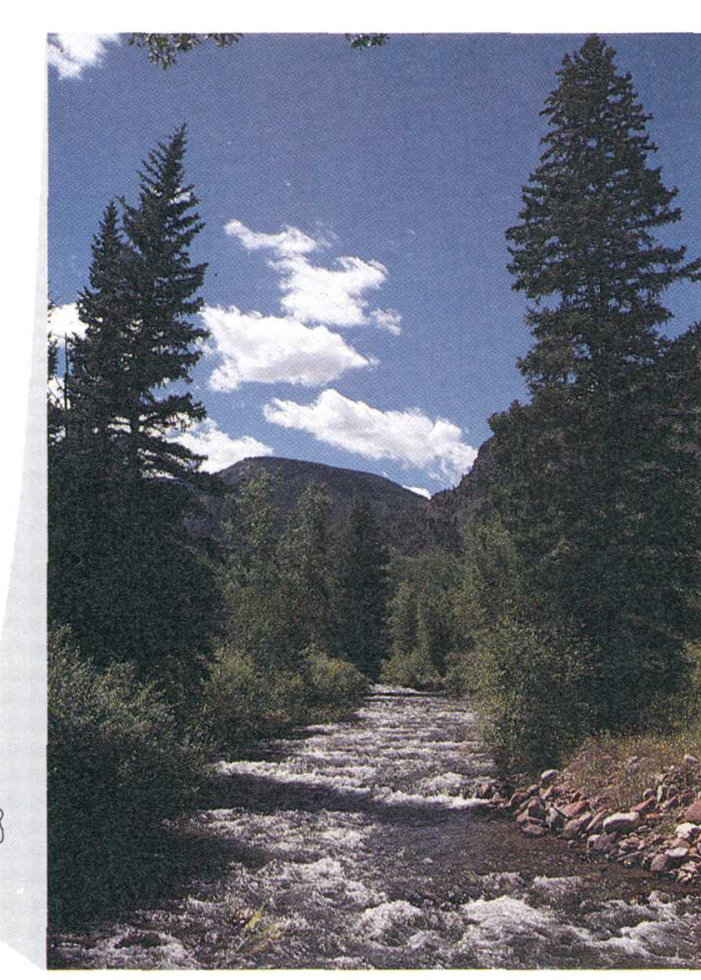

Maroon Creek in the Roaring Fork River mountain streams in Area 58 .
mage area is typical of perenial

EXPLANATION

Colorado River

$\square$ Gunnison River

HYDROLOGIC UNIT CODE

Region 7 Accounting Unit $\rightarrow+$

CATALOGING UNIT BOUNDARY

* PARTIAL CATAloging U.S. Geological Survey, 1974

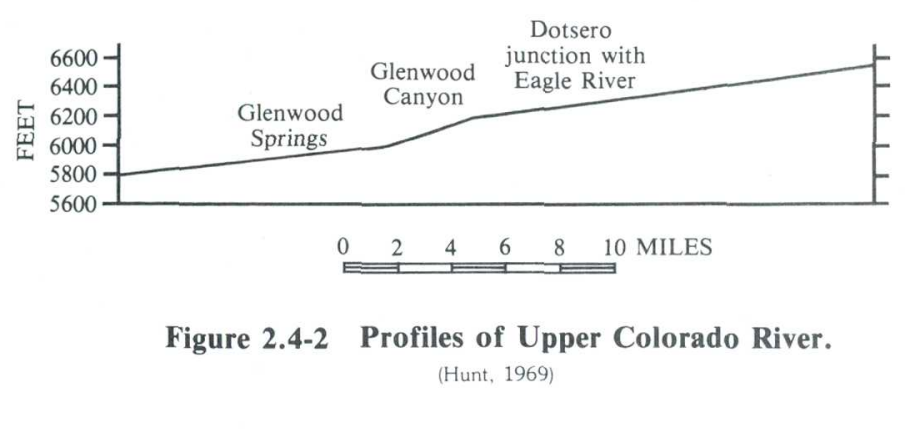

2.0 PHYSICAL FEATURES--Continued 2.4 Drainage 


\title{
2.0 PHYSICAL FEATURES--Continued 2.5 Soils
}

\section{Twenty-Three Different Soil Units Occur in Area 58}

\author{
Light-colored, alkaline soils formed under dry conditions \\ are typical in the study area.
}

Soil formation is the result of the interaction of climate, living organisms, parent material, topography, and time. Climate is the most influential of these factors because it controls two of the other factors. Climate determines the nature of the weathering by controlling the rates of the chemical and physical weathering processes. The type of native vegetation and other organisms present in an area also are determined by climatic factors. The living organisms cause organic matter to accumulate, cycle nutrients, mix soil, and provide structural stability. Parent material determines the soil texture, the downward movement of water, and the chemical and mineral composition of the soil. Topography affects the rate water moves off the land surface and the rate of erosion. The length of time these processes have had to act affects the total development of the soil (Buckman and Brady, 1969).

The diversity of these factors in Area 58 has resulted in a complex pattern of soil distribution as shown in figure 2.5-1. The soil map units (numbered areas) each represent an area containing several different kinds of soils that commonly occur together. These soils do not necessarily have similar characteristics.

The colored areas in figure 2.5-1 correspond to standard soil orders, and map units group the soils at the subgroup taxonomic level. Soils are classified according to a number of soil properties, among them are color, texture, moisture content, and chemical composition. Soil classification and nomenclature are described briefly in Heil and others (1977) and Wilson and others (1975). For a detailed description of soil classification see U.S. Soil Conservation Service publication "Soil Taxonomy-A Basic System of Soil Classification for Making and Interpreting Soil Surveys."

The affect of climate and topography on soil distribution is illustrated in figure 2.5-1. The Inceptisols are found only at elevations greater than 11,000 feet, and because of the greater amounts of precipitation at the higher elevations, these soils are acidic. At the opposite extreme, the Entisols are found at the lowest elevations that range from 3,500 to 7,500 feet. This part of Area 58 is in the Plateau province, and the soils are very alkaline and often calcareous because of small precipitation amounts. The other three soil orders are intermediate to the Inceptisols and Entisols (Heil and others, 1977).

The majority of the soils in Area 58 are deep, loamy, well-drained soils that are alkaline. The individual map units and several characteristics associated with each are listed in table 2.5-1. Each soil type has a number of characteristics that determine its suitability for different uses. A general indication of the range of values for several soil characteristics and the limitations of the soils is provided in table 2.5-1. For site-specific soil information, a detailed soil survey needs to be consulted. Soil-survey information is available for a large part of Area 58 and may be obtained from either a county U.S. Department of Agriculture, Soil Conservation Service office or from the Office of the State Conservationist, U.S. Department of Agriculture, Soil Conservation Service, Denver, Colorado.

Three important soil properties are $\mathrm{pH}$, permeability, and soil depth. Soil pH can affect the availability of nutrients for plants. When $\mathrm{pH}$ is in the alkaline range (greater than 7.0), metals such as iron, manganese, and zinc become less available. At $\mathrm{pH}$ values less than 5.0, metals such as aluminum, iron, and manganese can become available in quantities large enough to be toxic to some plants. Permeability is a measure of the ability of water or air to move through the soil and is expressed as a rate in inches per hour. Permeability is a function of the soil structure and is controlled by the size of the spaces between individual soil particles. Soil depth indicates the thickness of the soil before solid rock is reached. Shallow soils such as Typic Torriorthents (soil map unit 12) have little potential for agricultural or other uses. Other possible limitations associated with the different map units are indicated in the comments column of table 2.5-1. 


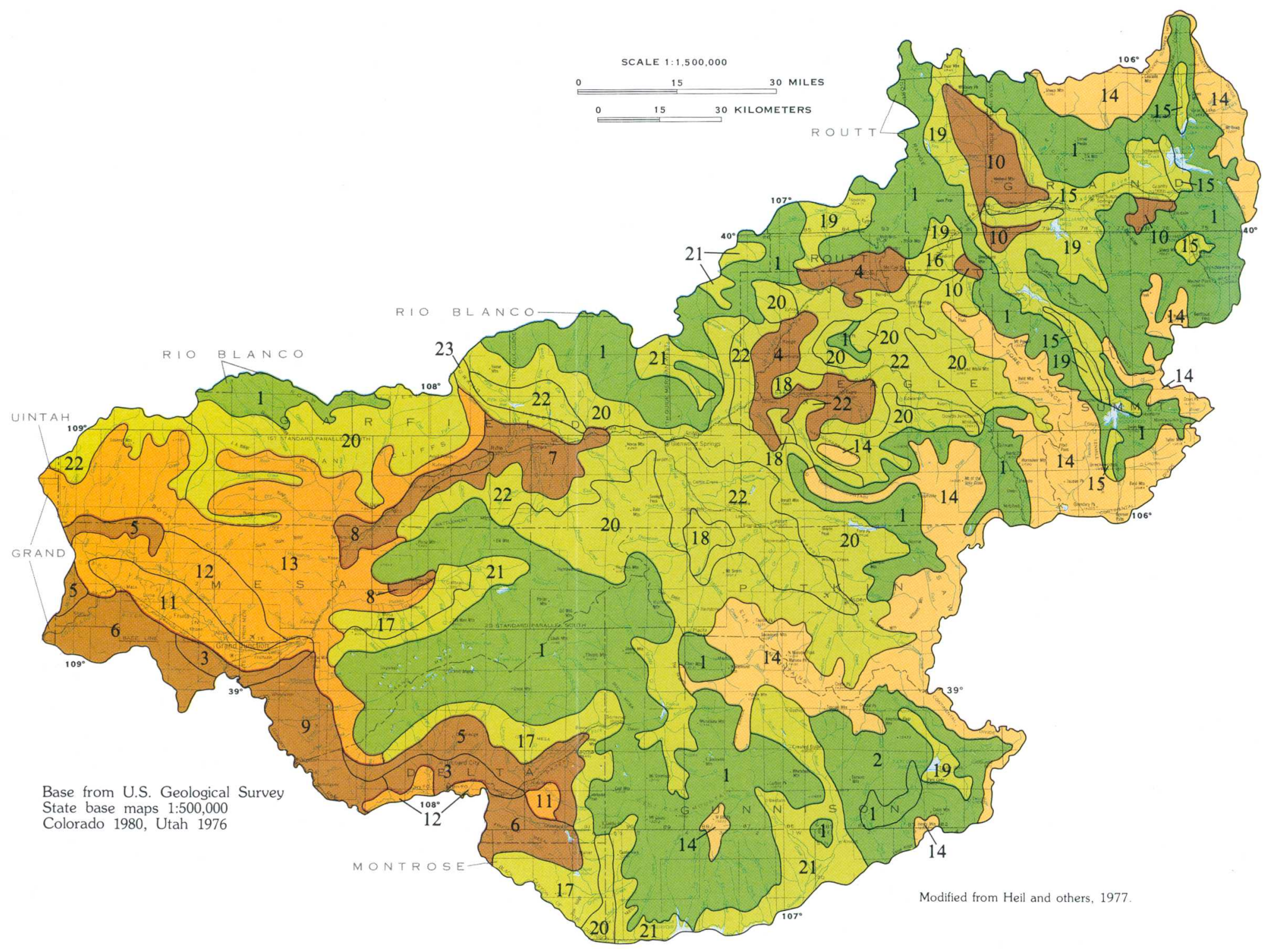

Figure 2.5-1 Standard soil orders and map units.

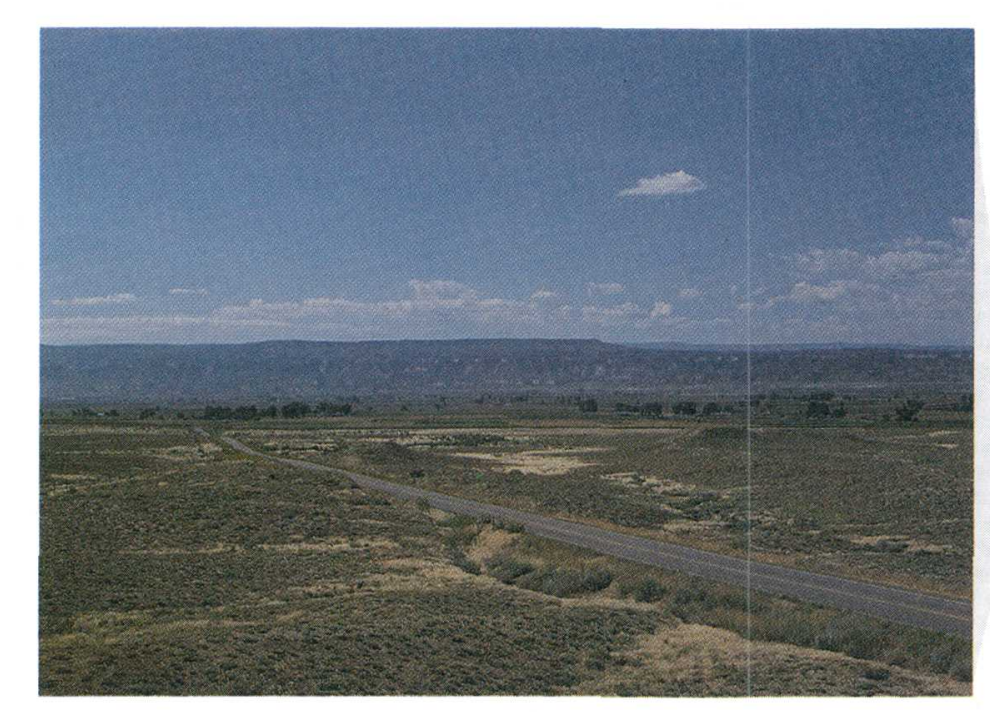

Alkaline entisols typical of semiarid western parts of Area 58.
Table 2.5-1 Soil orders and map-unit characteristics

\begin{tabular}{|c|c|c|c|c|c|c|c|}
\hline & $\begin{array}{l}\text { Soiv orders } \\
\text { and map units }\end{array}$ & $\begin{array}{l}\text { Elevation } \\
\text { (thousands } \\
\text { of feet) }\end{array}$ & $\begin{array}{l}\text { Slope } \\
\text { (per- } \\
\text { cent) }\end{array}$ & $\mathrm{pH}$ & $\begin{array}{l}\text { Perme- } \\
\text { abilitity } \\
\text { (anches } \\
\text { per hour) }\end{array}$ & $\begin{array}{c}\text { Soil1 } \\
\text { depth } \\
\text { (inches) }\end{array}$ & Use comments ${ }^{1}$ \\
\hline & ALFISOLS & & & & & & \\
\hline 1 & $\begin{array}{l}\text { Typic cryoboralfs } \\
\text { (rock outcrops) }\end{array}$ & $7.5-11.5$ & $5-65$ & $5.6-7.3$ & $0.6-2.0$ & $20->60$ & Clayey to sandy; $>35$ percent rocks. \\
\hline & $\begin{array}{l}\text { Typic Cryoboralfs } \\
\text { ARIDSoLs }\end{array}$ & $9.0-11.5$ & $2-50$ & $6.1-7.3$ & $0.6-2.0$ & $20->60$ & Loany, exodable, acidic.. \\
\hline 3 & Typic Haplargids & $5.0-6.0$ & $0-5$ & $7.4-8.4$ & $0.6-2.0$ & 260 & Prime farmland with few limitations. \\
\hline 4 & $\begin{array}{l}\text { Borollic Haplargids- } \\
\text { Ustic Torriorthents }\end{array}$ & $7.0-9.0$ & $0-30$ & $6.6-8.4 *$ & $0.6-2.0$ & $<20->60$ & $\begin{array}{l}\text { Uses } 1 \text { imited by slopes, soil depth and } \\
\text { strength; } 33 \text { percent rock fragments. }\end{array}$ \\
\hline 5 & Ustoll ic Haplargids & $5.0-7.0$ & $0-5$ & $6.6-8.4 *$ & $0.6-20.0$ & $>60$ & $\begin{array}{l}\text { Dusty with strength and shrink-swel1 } \\
\text { limitations. }\end{array}$ \\
\hline 6 & $\begin{array}{l}\text { Ustollic Haplargids } \\
\text { (rock outcrops) }\end{array}$ & $5.0-8.0$ & $2-50$ & $6.6-8.3^{*}$ & $0.6-20.0$ & 20- >60 & $\begin{array}{l}\text { Many limitations due to slope, erodibility } \\
\text { and shallow soils. }\end{array}$ \\
\hline 7 & $\begin{array}{l}\text { Ustollic Haplargids- } \\
\text { Ustic Torriorthents }\end{array}$ & $6.0-7.0$ & $0-15$ & $6.6-8.4$ & $0.06-2.0$ & 20- >60 & $\begin{array}{l}\text { Limited strength, dustiness, and slope } \\
\text { are limitations. }\end{array}$ \\
\hline 8 & $\begin{array}{l}\text { Ustollic Natrargids- } \\
\text { Ustollic Haplargids }\end{array}$ & $5.0-6.0$ & $0-15$ & $6.6-8.4$ & $0.06-2.0$ & $>60$ & $\begin{array}{l}\text { Very limited by a akal inity, shrink-swel1 } \\
\text { and corrosivitity. }\end{array}$ \\
\hline & $\begin{array}{l}\text { Typic Calciorthids- } \\
\text { Ustic Torriorthents }\end{array}$ & $5.0-6.0$ & $2-30$ & $7.4-9.0 *$ & $0.6-2.0$ & 20- >60 & $\begin{array}{l}\text { Dustiness and limited water availabiility } \\
\text { limit uses; }>35 \text { percent rocks. }\end{array}$ \\
\hline 10 & $\begin{array}{l}\text { Borollicic vertic } \\
\text { Camborthids } \\
\Rightarrow \quad \text { ENTISoIs }\end{array}$ & $7.0-9.0$ & $2-25$ & $7.4-9.0 *$ & $.06-.20$ & $20-40$ & $\begin{array}{l}\text { Limits are excess salt, } 1 \text { imited strength, } \\
\text { shrink-swel1 and slow percolation. }\end{array}$ \\
\hline 11 & Typic Torrifluvents & $4.8-6.5$ & $0-2$ & $7.4-8.4 *$ & $.06-2.0$ & $>60$ & $\begin{array}{l}\text { Prime cropland when irrigated; Severe } \\
\text { development } 1 \text { imits. }\end{array}$ \\
\hline 12 & Typic Torriorthents & $4.5-7.5$ & $2-45$ & $7.4-8.4 *$ & $.06-.20$ & $<20$ & $\begin{array}{l}\text { Shal low depth to bedrock, slopes, shrink- } \\
\text { swell limit uses. }\end{array}$ \\
\hline 13 & $\begin{array}{l}\text { Lithic Ustic } \\
\text { Torriorthents } \\
\text { (rrck outcrops) } \\
\quad \quad \text { INCEPTISOLS }\end{array}$ & $3.5-7.5$ & $2-30$ & $7.4-7.8 *$ & $0.6-2.0$ & $<20$ & $\begin{array}{l}\text { Limited by slope, depth to bedrock and } \\
\text { dustiness. }\end{array}$ \\
\hline 14 & $\begin{array}{l}\text { Pergelic Cryumbrepts } \\
\text { Pergelic cryochrepts } \\
\text { (rock outcrops) } \\
\text { MoLitsois }\end{array}$ & $3^{11.0-14.5}$ & $10-50$ & $5.1-6.0$ & $0.6-6.0$ & $20->40$ & $\begin{array}{l}\text { Significant erosion hazard; Severe 1imits } \\
\text { for all uses that disturb vegetation. }\end{array}$ \\
\hline 15 & Cryaquol1s, mixed & $7.8-10.0$ & $0-5$ & $5.6-6.0$ & $0.2-0.6$ & $>60$ & Wetness and flooding are problems. \\
\hline 16 & $\begin{array}{l}\text { Aridic Argiborolls } \\
\text { (rock outcropsp) }\end{array}$ & $6.0-8.5$ & ${ }^{15-50}$ & $6.6-7.8$ & $0.6-2.0$ & $20->60$ & Limited agricultural uses. \\
\hline 17 & $\begin{array}{l}\text { Aridic Argiborolls- } \\
\text { Aridic Haploborolls }\end{array}$ & $6.0-9.0$ & $2-50$ & $6.6-7.8$ & $.06-.20$ & 20-60 & $\begin{array}{l}\text { Slow permeability and slopes can be } \\
\text { limiting. }\end{array}$ \\
\hline 18 & Aridic Calciborolls & $7.0-9.0$ & $2-50$ & $7.9-8.4 \%$ & $0.6-20.0$ & $20->60$ & Shallow soils, stones, and slopes limit use. \\
\hline 19 & $\begin{array}{l}\text { Typic c croboborol11s } \\
\text { (rock outcorops) }\end{array}$ & $8.0-10.5$ & $2-50$ & $6.6-8.4$ & $0.6-2.0$ & $20->60$ & Limited by slopes and shallow soils. \\
\hline 20 & $\begin{array}{l}\text { Typic Cryoborol1s- } \\
\text { Typic Cryoboral fs }\end{array}$ & $7.0-11.5$ & $15-50$ & $5.6-7.8$ & variable & $20->60$ & Slopes are only major limitation. \\
\hline 21 & $\begin{array}{l}\text { Argic Cryoborolls- } \\
\text { Typic Cryoborolls }\end{array}$ & $8.0-11.0$ & $2-50$ & $6.6-7.3 *$ & $0.2-6.0$ & $20->60$ & $\begin{array}{l}\text { Limited by steep slopes, shrink-swe11, } \\
\text { frost action, stones. }\end{array}$ \\
\hline 22 & $\begin{array}{l}\text { Aridic Haploborolls- } \\
\text { Torriorthentic Happob } \\
\text { Aridic Argiborolls }\end{array}$ & 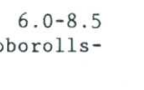 & $2-45$ & $6.6-7.8$ & $0.06-2.0$ & $20->60$ & Slopes only major limitation. \\
\hline${ }^{23}$ & $\begin{array}{l}\text { Lithic Haploborolls } \\
\text { (rock outcrops) }\end{array}$ & $5.5-8.0$ & $15-50$ & $6.1->8.0$ & 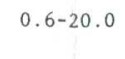 & $20->60$ & $\begin{array}{l}\text { Steep slopes, depth to bedrock and } \\
\text { droughtiness limit uses }\end{array}$ \\
\hline
\end{tabular}




\title{
2.0 PHYSICAL FEATURES--Continued 2.6 Vegetation
}

\section{Natural Vegetation Varies With Climate and Soils}

\author{
The natural vegetation of the region varies from shrub communities of \\ greasewood or sagebrush to forests of pine, fir, or aspen.
}

The distribution of vegetation is determined primarily by soil type and amount of precipitation, but the distribution also is affected by elevation, slope, and aspect. As discussed earlier, precipitation increases with elevation. Also, north slopes retain more moisture. The result is that plants with greater moisture requirements can be found at lower elevations on northern slopes and vice versa for southern slopes. The following discussion of vegetation communities is primarily from the U.S. Bureau of Land Management, 1979.

Greasewood is typical in areas that have an elevation of less than 6,200 feet, that receive less than 10 inches of precipitation per year, and also have a high water table. In similar areas without wet soils, saltbush becomes dominant. Big sagebrush (A on fig. 2.6-1) is found in both semiarid areas (less than 16 inches of precipitation and elevations of 5,000 to 7,000 feet) and in the mountain parks from 7,500 to 9,000 feet. The sagebrush community is particularly common in the Gunnison basin.

The pinyon pine-juniper association (B on fig. 2.6-1) usually is located at elevations just above the sagebrush (6,000 to 7,000 feet of elevation) and the sagebrush often is interspersed. Both of these associations have a sparse, herbaceous undergrowth. The mountain shrub community, typified by Gambel oak, forms a narrow band between the pinyon-juniper community and the sagebrush. Serviceberry and mountain mahogany are found in association with the oak.

Several forest communities are typical of the higher elevations. Ponderosa pine and Douglas fir are found from 6,500 to 8,500 feet in areas that receive 16 to 26 inches of precipitation per year. The pine usually is dominant in the dryer areas and the fir in wet areas. Aspen typically (C on fig. $2.6-1$ ) is located from 7,500 to 10,500 feet and has a lush understory associated with it that consists of forbs and grasses. Lodgepole pine is scattered throughout the subalpine areas typically between 8,500 and 11,000 feet of elevation on north-facing slopes. A spruce-fir association (D on fig. 2.6-1), composed of Engleman spruce and subalpine firs, is present at elevations between 8,500 and 12,000 feet where 20 to 35 inches of precipitation per year occurs.

Among the woodlands of the lower mountains and subalpine areas, mountain meadows ( $\mathrm{E}$ on fig. 2.6-1) are common. These are composed of a variety of grasses, wildflowers, and other herbaceous plants that vary with the available soil moisture. The alpine community ( $\mathrm{F}$ on fig. 2.6-1) begins at timberline (approximately 11,000 feet) and extends to more than 14,000 feet. Plants in this community range from tall grasses, sedges, and erect forbs at the lower elevations to cushion, rosette, mat, and low tufted plants at the higher elevations. More than 40 inches of precipitation is needed to sustain this habitat type.

In the dryer areas, stream banks and flood plains support a characteristic riparian community composed of trees and shrubs such as cottonwoods, box elder, birch, alder, hawthorn, and willows. Colorado blue spruce is typical from 7,000 to 9,500 feet and salt cedar below 6,000 feet. 


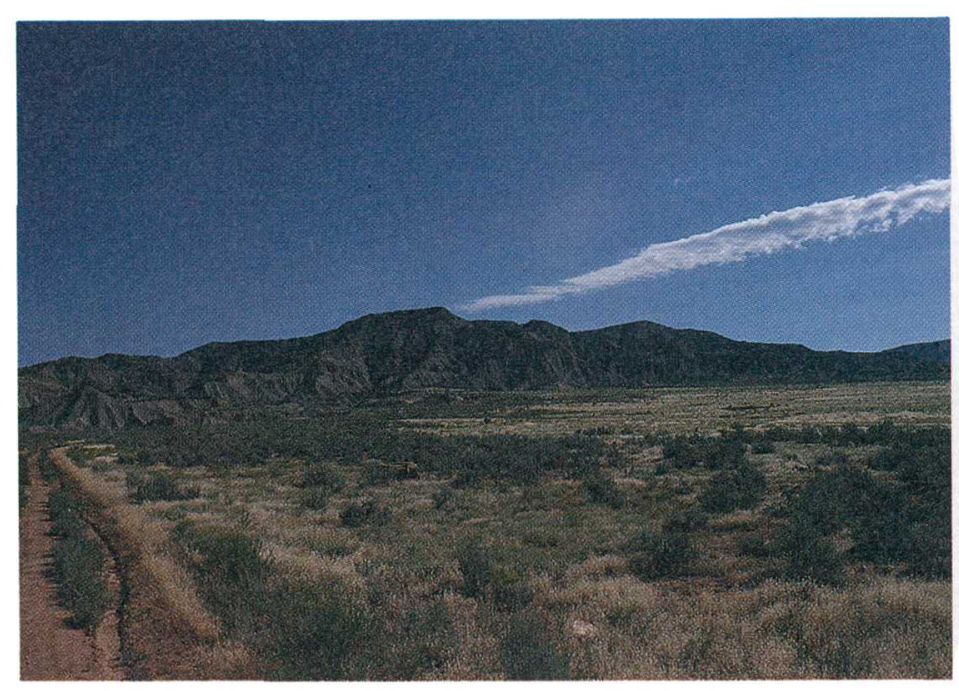

A. Sagebrush association found in semiarid parts of Area 58.

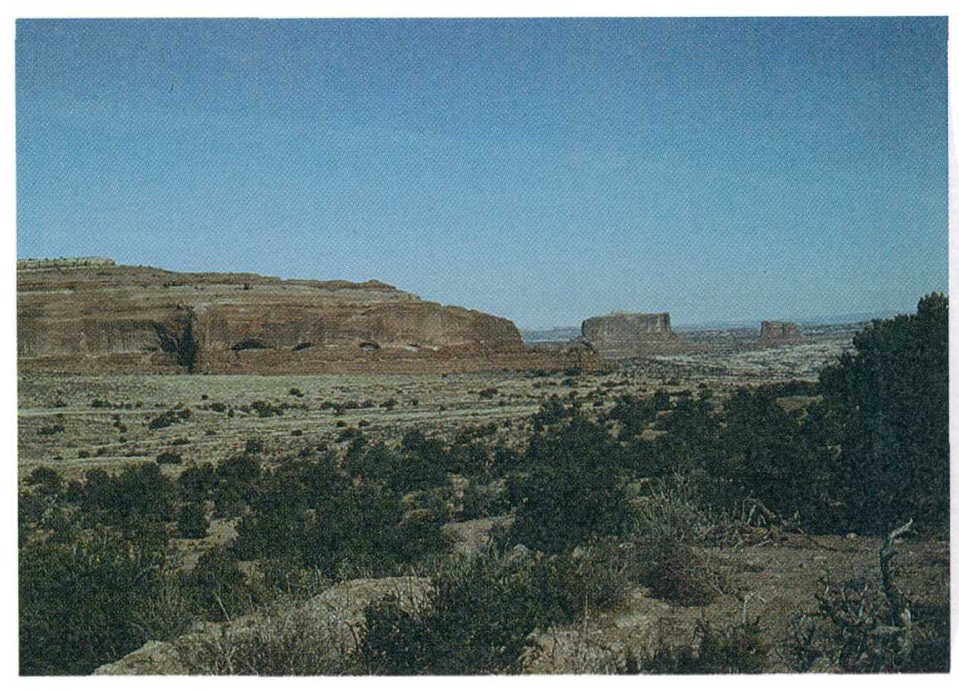

B. Piñon Pine-Juniper association found near Colorado National found at lower elevations.

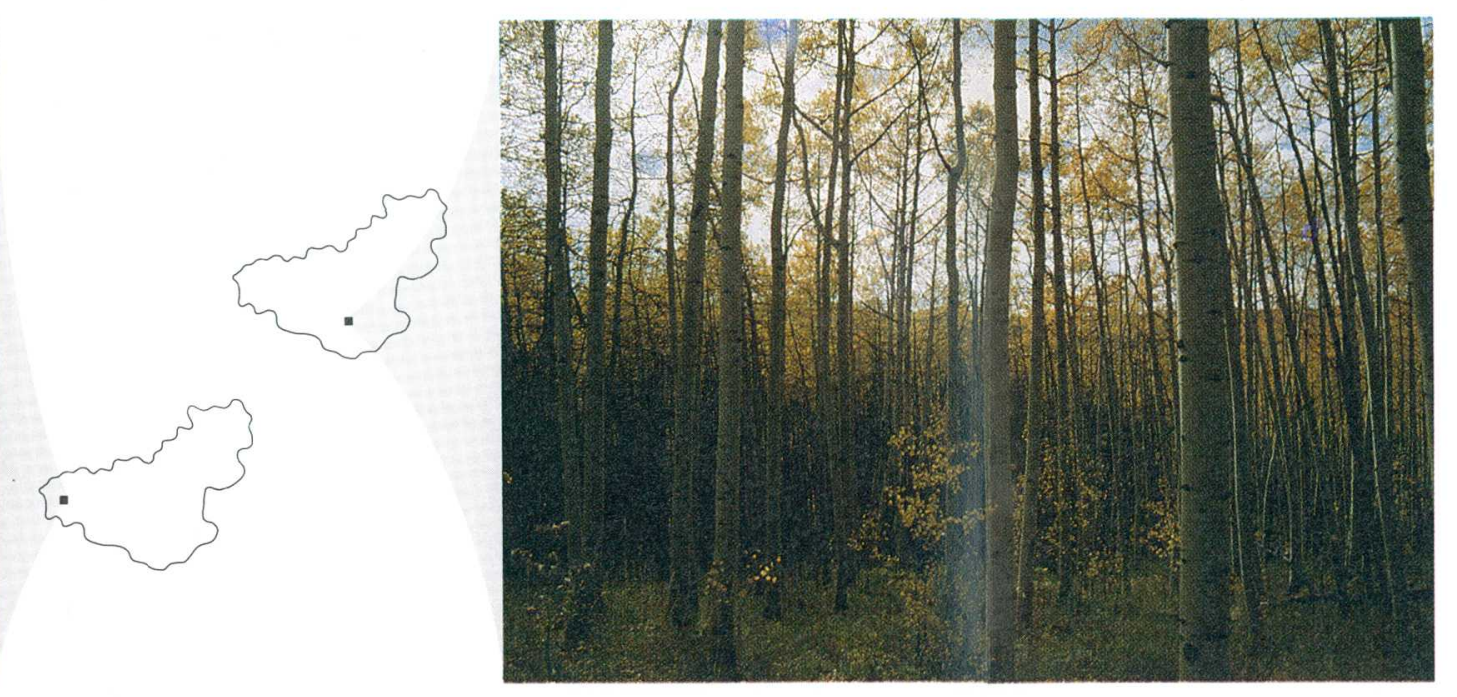

C. Typical aspen stand with lush understory of grasses and forbs.

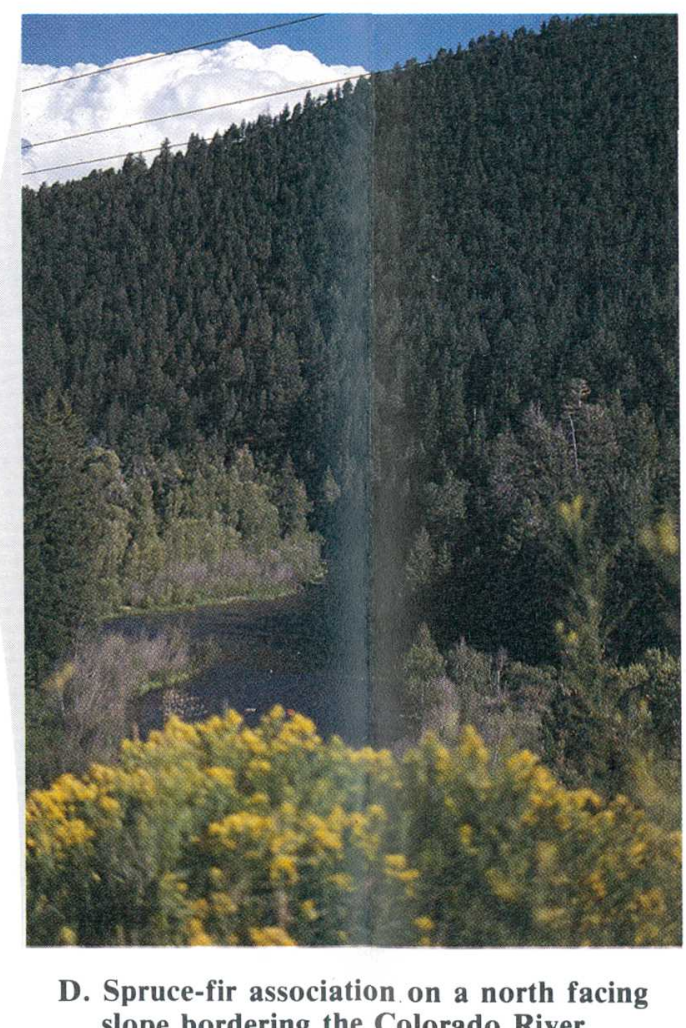

D. Spruce-fir association on a north facing
slope bordering the Colorado River.

Figure 2.6-1 Vegetation associations in Area 58.

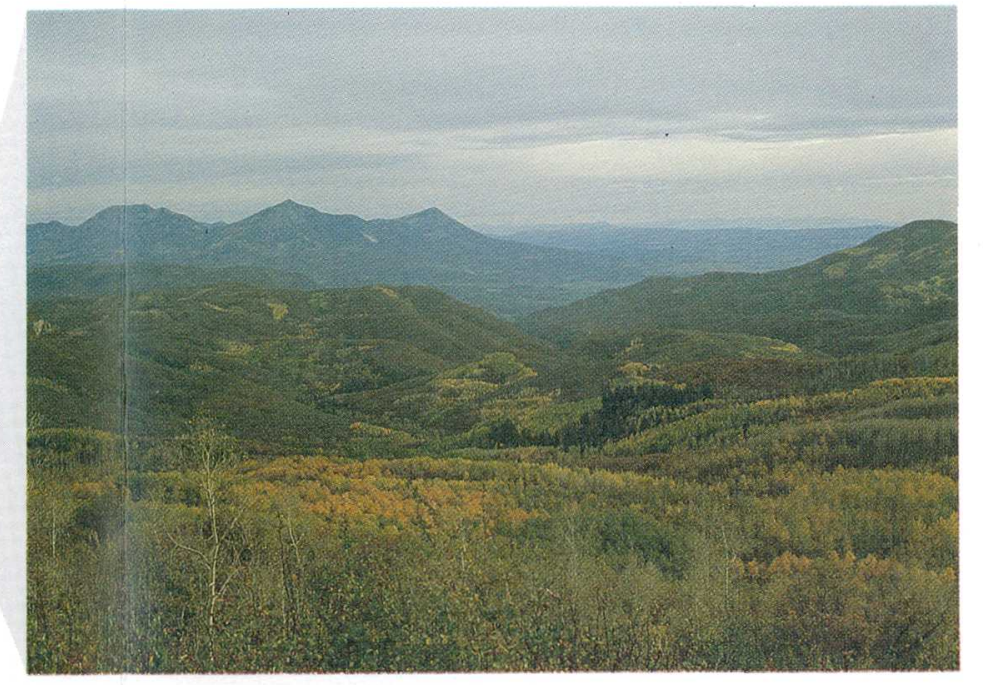

E. Mountain meadows often are intermixed with forests as is seen

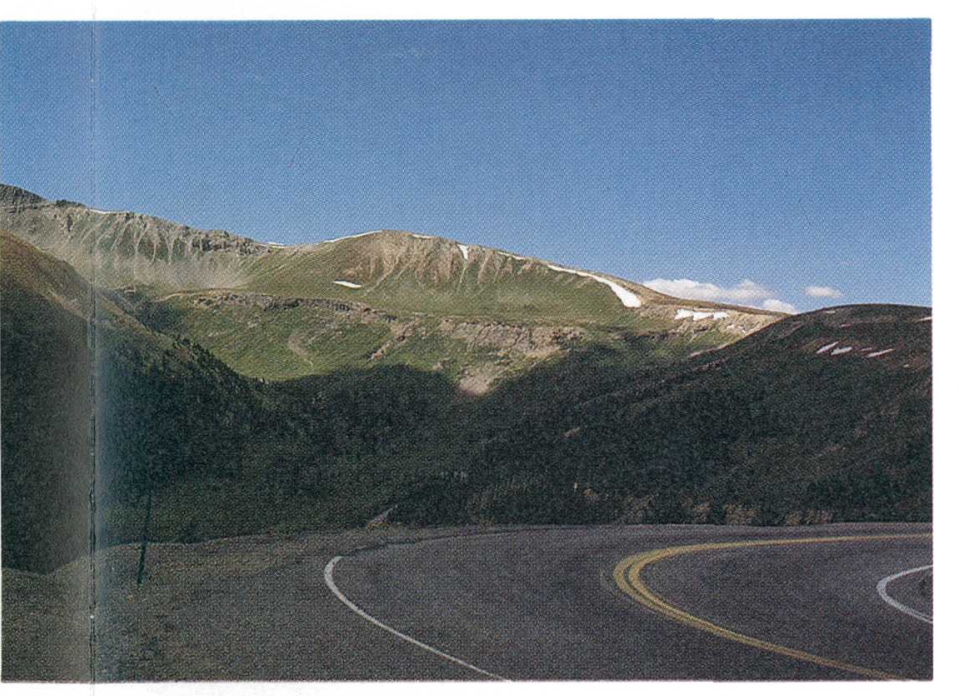

F. Alpine community near Independence Pass is typical of plant communities above the timberline. 


\title{
3.0 RESOURCE USE
}

\author{
3.1 Land Use And Ownership
}

\section{Land Uses Are Predominantly Woodland or Rangeland}

\author{
The majority of lands in the area are managed by the \\ U.S. Bureau of Land Management and the U.S. Forest Service.
}

Land designated for use as rangeland or woodland comprises the largest part of Area 58 as is shown in figure 3.1-1. Other principal land-use designations include cropland, recreation land, and urban land.

Agriculture is the traditional land use in the area. Most of the agricultural production is found in Delta, Garfield, and Mesa Counties. Livestock production is the principal activity using the large areas of rangeland available for foraging. Crops grown in the area include hay, field corn, wheat, barley, oats, sorghum, vegetables, and fruit. Little crop production occurs without irrigation because of the small precipitation levels. Orchards, although accounting for a relatively small part of the area's total crop acreage, represent the major fruitproducing area for the State.

Many of the mountain slopes and plateau areas are forested. Commercial tree species include lodgepole pine, Engleman spruce, and Douglas fir. Little commercial production has occurred in recent years because of poor economic conditions. Nearly all commercial timber stands are located within national forest lands. Much of this woodland is not commercially harvested but does provide valuable wildlife habitat and recreation opportunities.

Large parts of the study area have been set aside specifically for recreational activities. All or part of four National Park Service recreational areas and four wilderness areas are located in Area 58. A number of State parks and wildlife management areas also are located in the region. More than 10 ski areas operate in the area. As a result, tourism and other recreational activities are major industries.

Although individual operations are not large enough to show on the land-use map (fig. 3.1-1), mining is a major factor in the region. In addition to coal, there are a number of active oil and gas fields, primarily in Garfield County. Rich deposits of oil shale also occur in this same area. Several uranium mines also are active in the study area. The world's largest molybdenum deposit is on the area's eastern boundary in the headwaters of the Eagle River. Production of lead, zinc, silver, and gold occurs at scattered locations in the eastern parts of the study area.
Urban land is the smallest land-use category in this predominantly rural area. This category includes developed land found in the cities and subdivided land that is less than 50 percent developed. Large tracts of subdivided land are located in isolated mountain areas throughout the study area. Several of these urban areas are associated with development activities resulting from the expansion of the ski industry. The rapid expansion of energy-development activities, particularly the oilshale production proposed during the early 1980's, also has caused large areas in and around Rifle to become subdivided and developed.

Land ownership by counties is shown in table 3.1-1. The figures given are for the entire county even though some of the land is outside the study-area boundaries. In all instances, more than 60 percent of the county is within the study boundaries. Ownership by the Federal government accounts for approximately 71 percent of the land area compared with an average federal land ownership for the State of Colorado of 36 percent. The largest acreage is managed by the U.S. Forest Service, which administers almost 4.5 million acres comprising all or part of four national forests. The U.S. Bureau of Land Management is the second, major, single land manager, administering more than 2.5 million acres.

Mineral ownership often is separate from land ownership. As the Federal government released land to private ownership, it frequently retained the mineral rights to those lands. This has resulted in a complex pattern of ownership. Ownership of mineral rights has been presented in map form by the U.S. Bureau of Land Management for parts of the study area in a series of "Surface-minerals management" quadrangle maps at a scale of $1: 100,000$. These maps or additional information are available from the U.S. Bureau of Land Management, Colorado State Office, 1037 20th Street, Denver, CO 80202.

Discussion in this section of the report was compiled primarily from the U.S. Bureau of Land Management (1979 and 1983a) and Moran and Wentz (1974). Public land statistics are compiled annually by the U.S. Bureau of Land Management (U.S. Bureau of Land Management, 1984). 


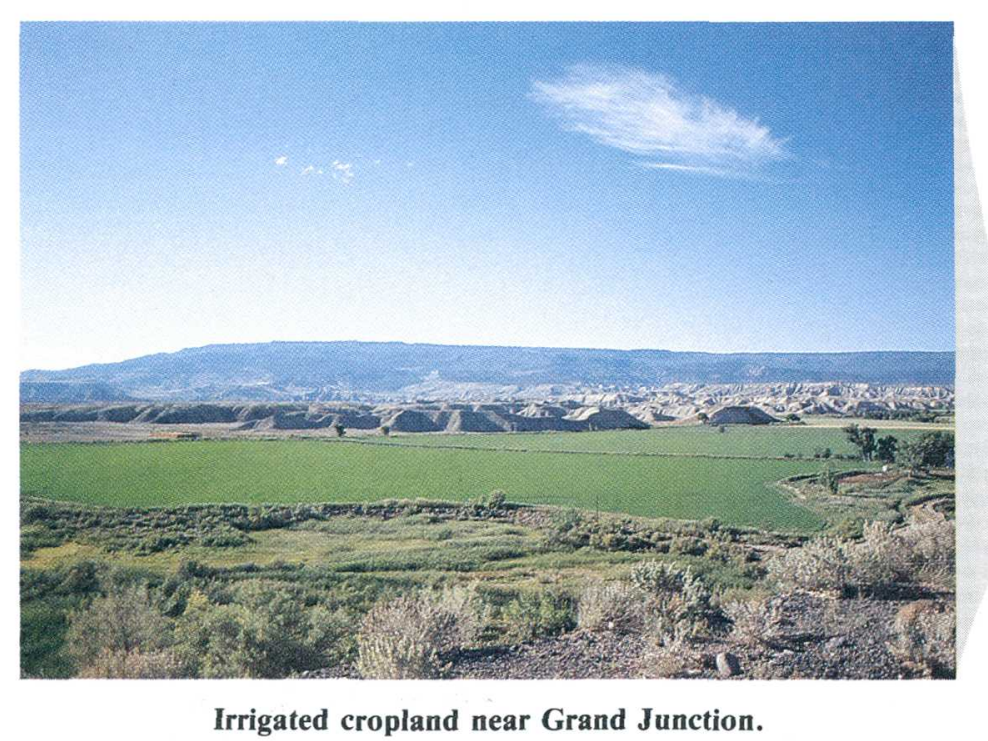

Irrigated cropland near Grand Junction.

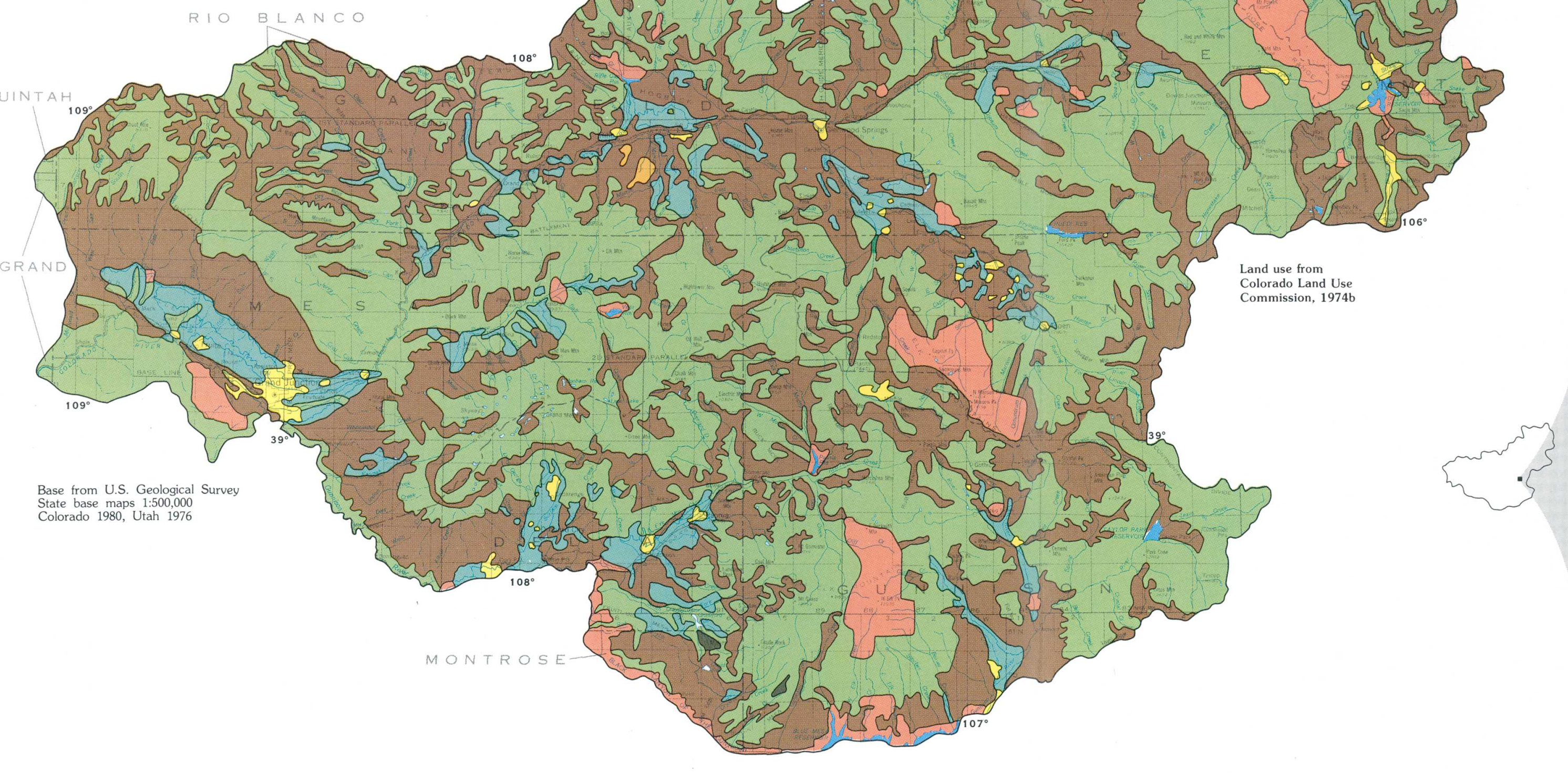

EXPLANATION

IRRIGATED CROPLAND, PASTURELAND, AND HAYLAND-Include land used for the production of adapted irigated and
irrigated forage or irrigated pasture. Also included are
orchard and vineyard crops.

NON-IRRIGATED CROPLAN-IIncludes land used for the production
of adapted non-irrigated crops.

RANGELAND AND/OR NON-IRRIGATED PASTURELAND-Includes
land used for grazing by livestock and big game animals on which the natural plant community is dominated by grasses,
grass-ike plants, and shrubs or land sued primarily for the
production of adapted domesticated forage plants which
are grazed by livestock.

WOODLAND-Includes land used primarily for the production of adapted wood crops and to provide tree cover for waters
protection, beautification, and wildlife habitat.

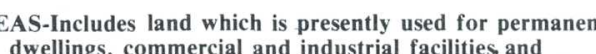
associaged service facilities and land which is inatted
and being sold. This category also includes airport
facilities,

RECREATION LAND-Includes land used primarily for recreation, includes state parks and wild dife management areas
and federal parks, monuments, wilderness, and
primitive areas. des large bodies of
or greater in size.

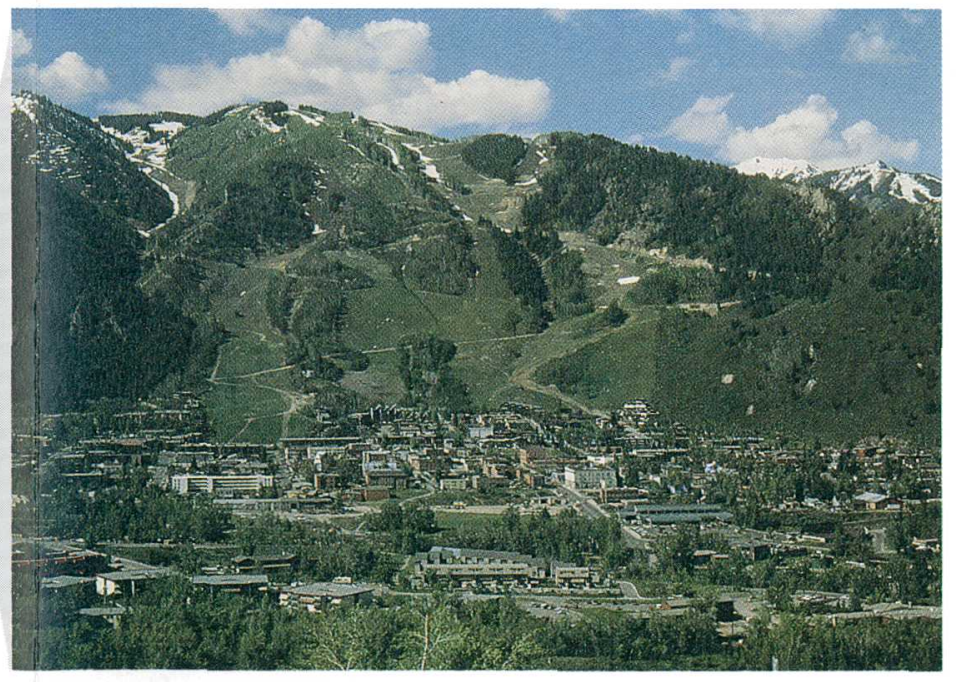

Ski resorts such as Aspen are common recreational land uses.

3.0 RESOURCE USE 


\subsection{RESOURCE USE--Continued}

3.2 Coal Resources

\section{During 1982, 4.5 Million Tons of Coal were Produced}

The Uinta Coal Region, the principal coal-producing region in

Approximately 25 percent of the Uinta Coal Region is within the study area; the remainder is in northwestern Colorado and eastern Utah. Area 58 coal field are shown in figure $3.2-1$. The area is bounded by the Grand Hogback on the east, the Utah State line on the Fork Valley and Gunnison Uplift on the south and southeast. For the most part, the coal area coincides with the Piceance structural basin. The southeastern part is marked by the igneous dikes, laccoliths, and sills of Tertiary age associated with the formation of the Elk and West Elk Mountains. The heat associated with this ig neous activity increased the rank of much of the coal in the adjacent filds. Coal rank in the region ranges from he Crested Butte and Carbondale fields. Anthracite is considered the highest quality coal. The Mesaverde Group of Late Cretaceous age contains the coal-producing formations.

Landis (1959) developed estimates of coal reserve for 14 inelds in Colorado where coal beds are greater 3,000 feet (table 3 2-1). Landis' coal-reserve estimate re for the original in-place reserves. The followin discussion of the coal fields in Area 58 is based primary on his work. Supplemental information is provided by Ladwig (1983) and Speltz (1976)

The Book Cliffs field extends from the Colorado-Utah State line to the Colorado River. Coal is found in the ich intertongues with the Mesaverde Group. The coal is primarily high-volatile C bituminous with some high-volatile B present. Total original reserves equaled 2,300 million short tons in 55-square-mile area. An additional 145 square miles also may have minable reserves. During 1983 there were Bour mines permitted by the State of Colorado in the production for these mines totaled 70,765 tons. All four mines are underground operations. The Grand Mesa field is located along the west and
suthwest edges of Grand Mesa in Mesa and Delta
The Carbondale field extends northward from the drainage divide between the Crystal and Slate Rivers in Gunnison County through Pitkin County to an area of the coal in this field ranges from high-volatile $\mathrm{C}$ bituminous to anthracite. Original in-place reserves have (4) possibly are minable.

There are eight permitted mines (table 3.2-2) in the Carbondale field, and 1982 production equalled 638,043 short tons. Only three of the mines were active during coking-quality coal.

The Grand Hogback field is located in the area from about 40 degrees latitude, north of Area 58, to just west of Glenwood Springs. Coal rank generally is high-volatile $B$ bituminous. The original inplace reserves have bee estimated to be 885 million short tons in a 43-square mile area. This area is almost entirely within the study outside the study area may bo minated within and presently no permitted mines in this field and, therefore, no production in 1982.
Two coal fields outside of the Uinta Coal Region are located in Area 58. The first field, Middle Park field, is located in the ex and probably is an extension of the North Park Coal and and probably are correlative with the Coalmont Forma trom this field, and nork field. No coal has been produced been made.

The second field, the Gunnison River field, is located along the Gunnison River in east Delta County and extends northwestward past Grand Junction to the westerstudy area boundary. This feld generally is considere part this area the Gunnison River field. No commercial pro duction has occurred in the area within the study boundaries. The coal appears to be bituminous, and bed thickness may be from 2 to 4 feet. Speltz (1976) makes a rough estimate that strippable coal resources
Five permitted mines (table 3.2-2) are located in the Grand Mesa field; three of these mines were producing during 1983 . Total 1982 production for this field was 58 is located in this field. The other mines are underground.

The Somerset field is located primarily in Gunnison County and includes Coal Creek Valley east of Mt. Gur nison. The coal rank is high-volatile $\mathrm{C}$ and $\mathrm{B}$ bituminous. Coals in this area occur in the Paonia and Bowie Members of the Williams Fork Formation. The original in-place reserves are estimated to be 3,300 million short

As of 1983, there were seven permitted mines (table 3.2-2) in the Somerset field, five of which were producing. Total production for 1982 from this field was $2,649,913$ short tons. This is the largest production in this field produce coking-quality coal.

The Crested Butte field occupies the southeast end of the Uinta Region. Because this field is located next to the Elk and West Elk Mountains, the coal beds are folded and faulted, and igneous intrusions are present making the whole area quite structurally complex. Coa vank varies from high-volatile $C$ bituminous to an thracite. An orignal 244 million short tons were present possibly are minable. Fifteen percent of the reserves are thought to be anthracite coal.

Only one permitted mine is present in the Crested Butte field. It was idle during 1983, but during 1982 produced 7,103 short tons of coal. 
Table 3.2-1 Coal reserves, resources and range of analyses for Area 58 coal fields (FFrom Landis, 1959 and Ladwig, 1983,)

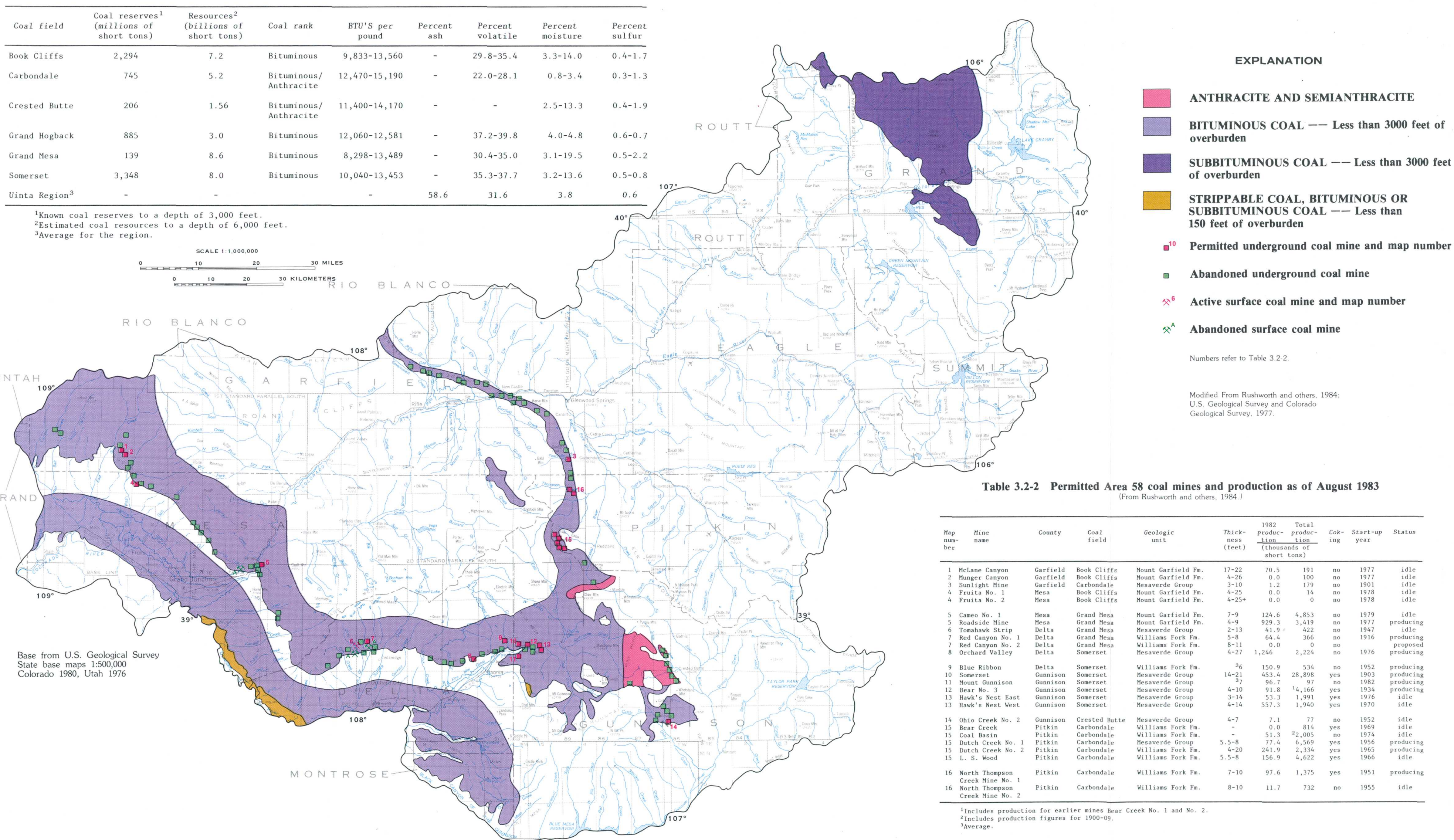




\subsection{RESOURCE USE--Continued \\ 3.3 Water Use}

\section{Irrigation is Principal Water Use}

\section{Total estimated annual water use for Area 58 is 3.3 million gallons per day.}

Water used for irrigating agricultural crops accounts for 80 percent of all water use in Area 58 (fig. 3.3-1). Most of the irrigation occurs in Delta, Garfield, and Mesa Counties, which is the most arid region of the area. Irrigated land in this area is used for hay, corn, wheat, barley, fruit, and vegetable production and as pastureland. Only relatively small amounts of land are irrigated in other counties within the area.

Self-supplied industrial water use totals 490.6 million gallons per day (table 3.3-1) and is the second largest water-use category. Included in this category are thermoelectric power generation, mining, mineral processing, food processing, and other industrial activities. Thermoelectric power uses are principally coal-fired powerplants that use only about 5.2 million gallons per day.

Water for rural uses excluding irrigation accounts for about 3 percent of the water use. The majority of this water is used for livestock.

Public water supplies use about 66.7 million gallons per day and account for only 2 percent of the water usage. The largest towns in the area are Grand Junction, Glenwood Springs, Delta, and. Gunnison.

Because of abundant surface-water supplies in the area, ground-water withdrawals are only about 32 million gallons per day. This is about 1 percent of the water use in the area.
Consumptive water use represents water that is no longer available because it has been evaporated, transpired, incorporated into products or crops, consumed by man, or otherwise removed from the water environment. In Area 58, 11 percent of the total water used is consumed. The largest loss is through irrigation. The percentage of loss is relatively small compared to a total loss from just irrigation that is 23 percent nationally (Solley and others, 1983, p. 32).

Another major group of water uses are instream uses. These are water uses such as boating, fishing, and hydroelectric power generation that are dependent on the amount of water flowing in a stream or the amount stored in a reservoir. As an example, certain levels of water need to be maintained in a stream in order to protect existing fish habitat. If offstream uses, as described above, become great enough, flow levels can be decreased to the extent that conflicts with instream uses can occur. In general, flows in perennial streams in Area 58 are sufficient to supply both instream and offstream uses. At present, only the instream-flow needs for hydroelectric power generation have been quantified for the area. Estimated instream-flow requirements for hydroelectric power generation in the Colorado River are 1,060 million gallons per day and in the Gunnison River, 3,500 million gallons per day (R. T. Hurr, U.S. Geological Survey, oral commun., 1984). All instream uses are nonconsumptive uses. 

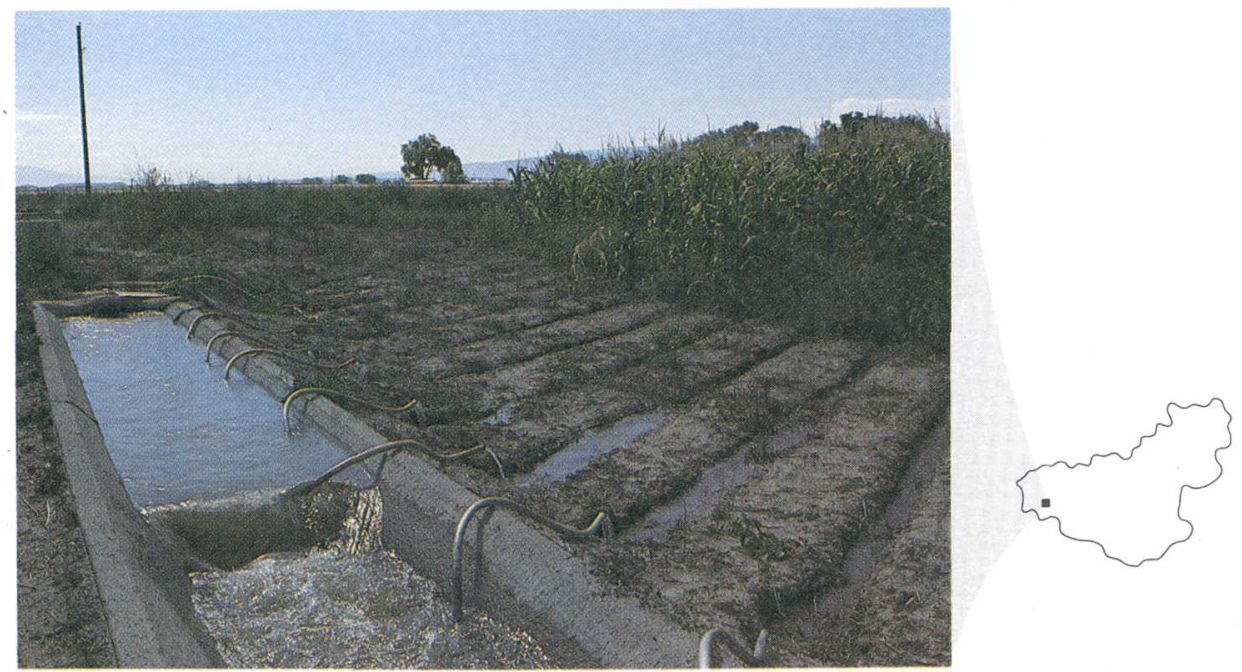

Irrigation such as this system in Mesa County is the principal water use in Area 58.
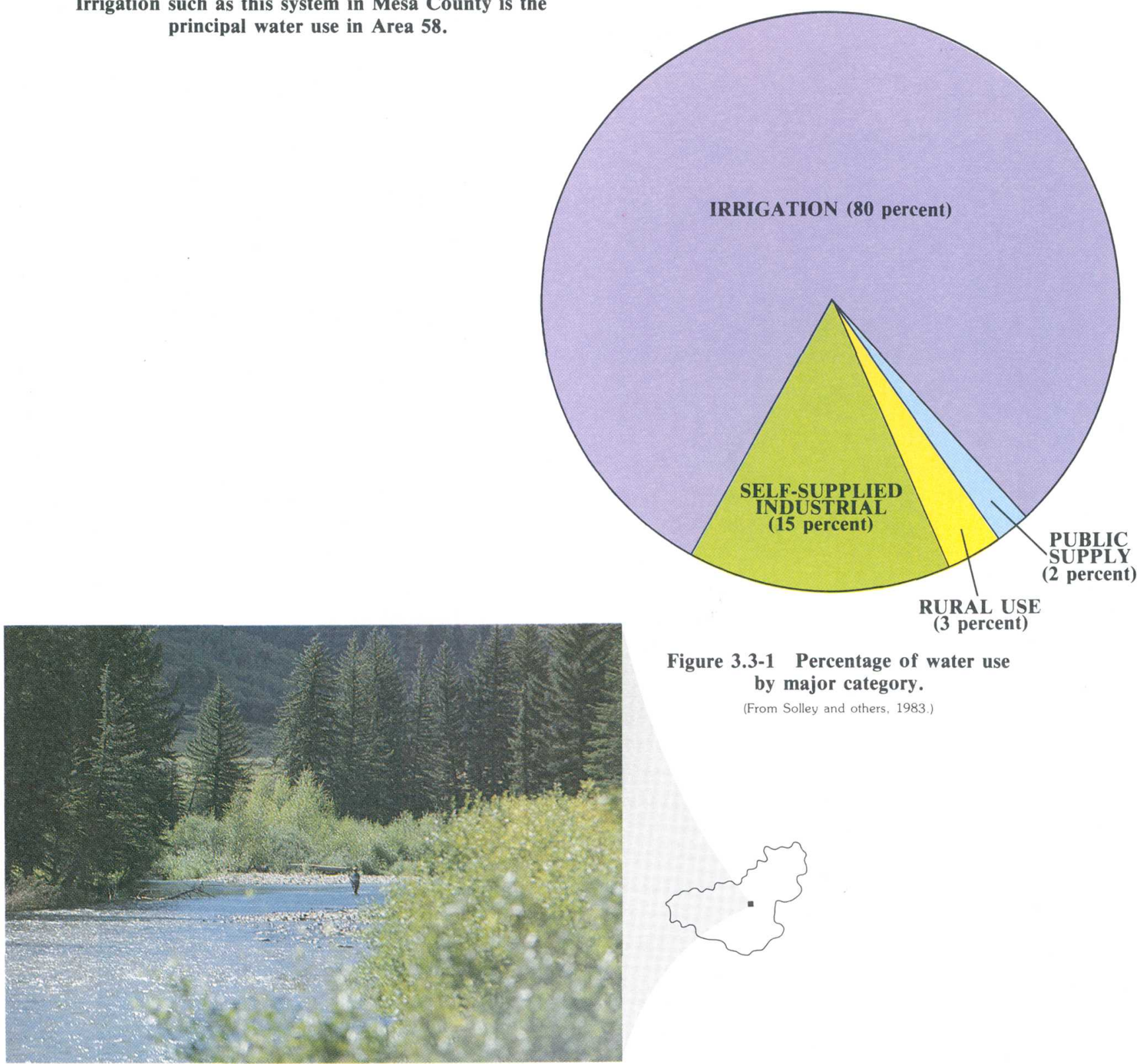

Figure 3.3-1 Percentage of water use by major category.

(From Solley and others, 1983.

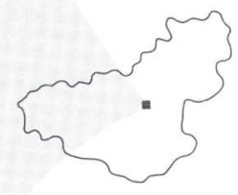

Instream water uses such as fishing represent an important nonconsumptive water use. 


\title{
4.0 SURFACE-WATER QUANTITY \\ 4.1 Hydrologic Studies
}

\section{Numerous Reports Describing Hydrology of Area are Available}

\author{
The U.S. Geological Survey has published numerous reports describing \\ the hydrologic characteristics of the area; most of these reports \\ have been published since 1976.
}

The U.S. Geological Survey has conducted hydrologic studies in and adjacent to Area 58 for many years. The results of these studies are available in numerous published reports, most of which were published since 1976. A large proportion of these studies were designed to obtain hydrologic data in areas of proposed or potential coal- and oil-shale resources development. The location of these specific studies relating to surfacewater quantity is shown in figure 4.1-1, and reference to the published reports is given in the accompanying explanation. Selected reports pertaining to all or nearly all of Area 58 also are listed.

Two studies relating surface-water quantity to coal-resources development have been completed (Alley and others, 1978a and 1978b). These two studies provide a preliminary evaluation of the quantity and quality of water resources available for hydraulic coal mining in the Grand Hogback and Crested Butte coal fields. A study currently is being conducted in the drainage basin of the North Fork Gunnison River to determine the regional water-resources system in the area of the Somerset coal field (Hawkinson and Lystrom, 1983; p. 27).

Three reports (Adams and others, 1985; Galyean and others, 1985; and Patt and others, 1982) are compilations of hydrologic data obtained in the Roan Creek and Parachute Creek basins. The purpose of the data is to provide baseline hydrologic information in areas of potential oilshale development. A technical report using this data is in preparation (study 10, fig. 4.1-1; Hawkinson and Lystrom, 1983, p. 20). Hydrologicinformation needs associated with oil-shale development were described by Taylor (1982b).

Evaporation from two reservoirs in Area 58, as well as information regarding other reservoirs out- side the area, are described by Ficke and others (1977) and Spahr and Ruddy (1983). Quantification of evaporation from reservoirs is important because the large amount of surface-water storage in the area in combination with the generally semiarid climate can result in significant evaporation rates. Another report (Alley and others, 1979) describes the hydrologic effects of diverting streamflow from one basin to another basin located on the opposite side of the Continental Divide, via Dillon Reservoir.

Most of the area-wide studies, which include adjacent areas, provide information on the streamflow and basin characteristics for some of the many gaging stations that have been or are being operated. The reports resulting from these studies include Elliott and others (1982), Petsch (1980; 1983), and Richter and others (1984). The reports by Kircher and others (1985) and Livingston (1970) present techniques for estimating different streamflow characteristics on the basis of basin characteristics, whereas the report by McCain and Jarrett (1976) only presents techniques for estimating floodflows.

The two reports by Iorns and others (1964; 1965 ), although about 20 years old, are noteworthy because they present a fairly detailed analysis of the water resources of the Upper Colorado River Basin. The authors divided their study area into three subareas, one of which nearly coincides with Area 58. These reports explain and summarize the water-resources data available for the area through the 1957 water year. The two reports by Iorns and others $(1964 ; 1965)$ present good baseline information that can be used to detect changes, if any, in the hydrologic characteristics of the area since about 1957. 

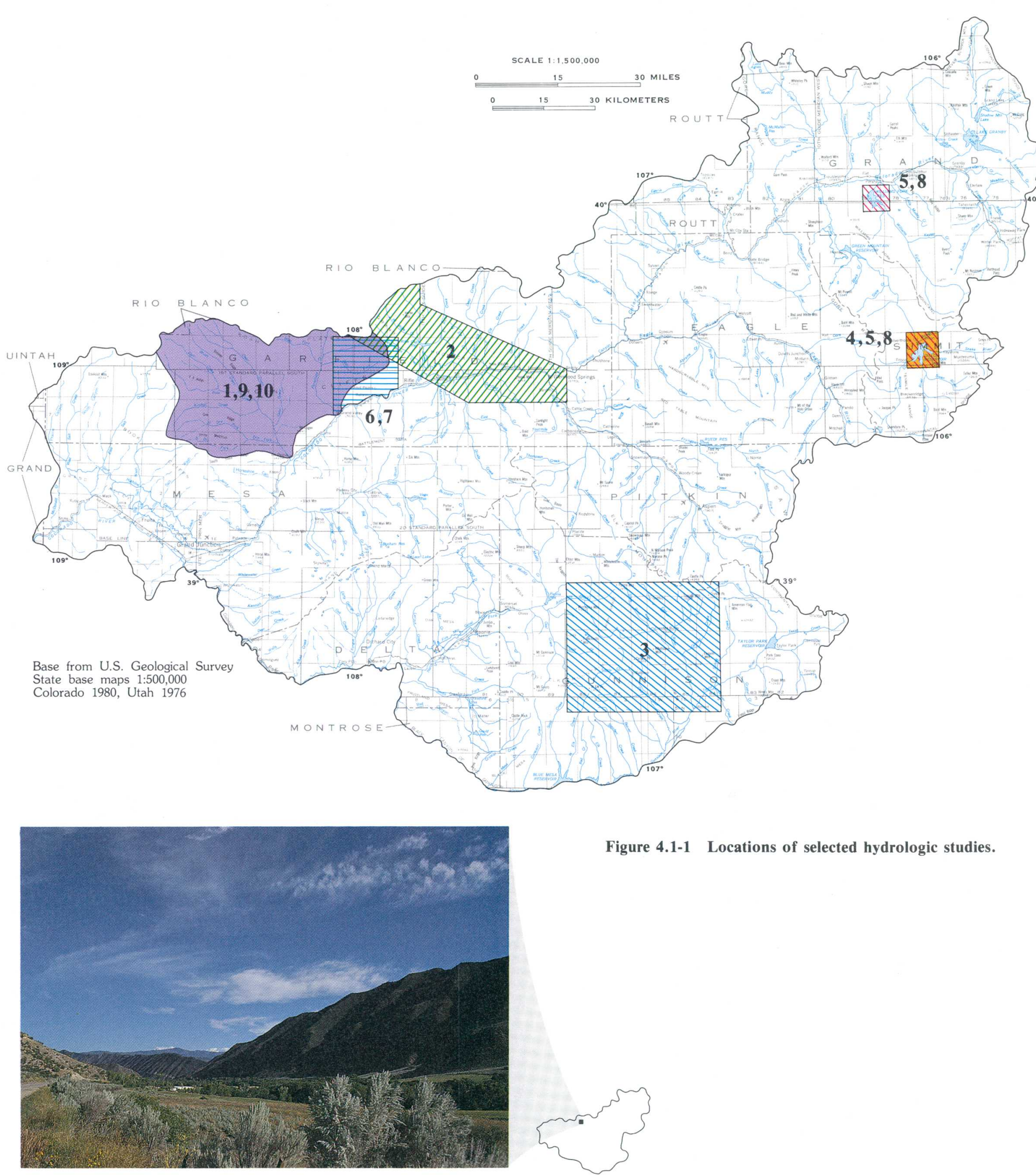

Figure 4.1-1 Locations of selected hydrologic studies. The Grand Hogback, a prominent physiographic feature containing
coal-bearing beds in the Iles and Williams Fork Formations.

\section{EXPLANATION}

STUDIES IN SPECIFIC PARTS OF AREA 58, MAY INCLUDE SOME ADJACENT AREAS.

1 Adams and others (1985)

Alley and others (1978a)

Alley and others (1978b)

4 Alley and others (1979)

S17 Ficke and others (1977)

6 Galyean and others (1985) (A similar report compiling data for 1982-83 is in preparation.)

7 Patt and others (1982)

(2) Spahr and Ruddy (1983)

9 Taylor (1982b)

10 Hydrology of Parachute Creek and Roan Creek basins, Northwestern Colorado (current ,1984, study)

AREA-WIDE STUDIES; ALSO INCLUDE ADJACENT AREAS

Elliott and others (1982)

Herbert (1983)

Iorns and others (1964)

Iorns and others (1965)

Jarrett and Costa (1982) (A more detailed

report is in preparation)

Kircher and others (1985)

Livingston (1970)

McCain and Ebling (1979)

McCain and Jarrett (1976)

Petsch (1980)

Petsch (1983)

Richter and others (1984) (An additional technical report will be available in the near future)

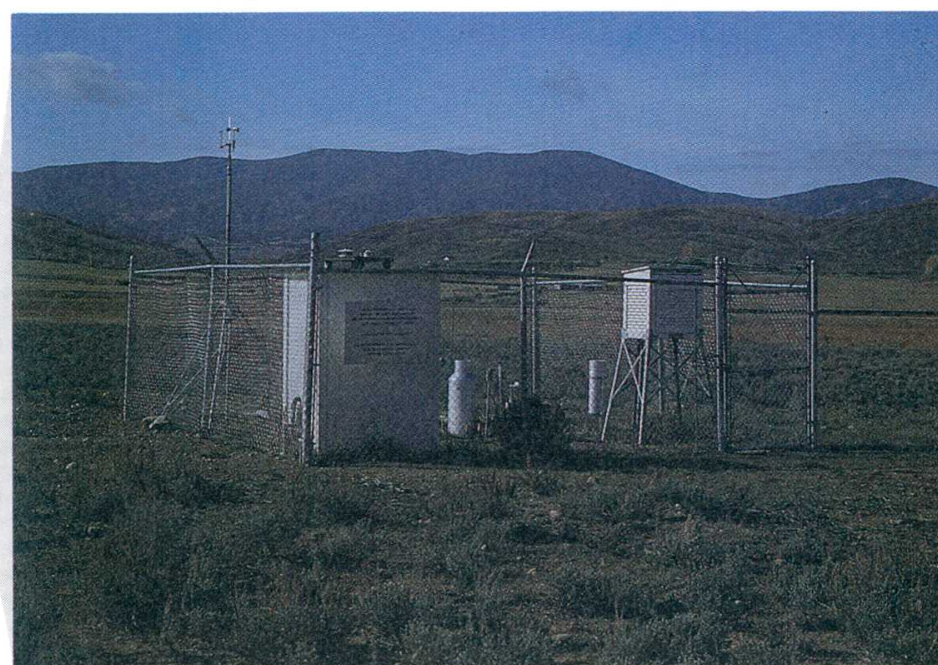

Instrument cluster for obtaining climatological data

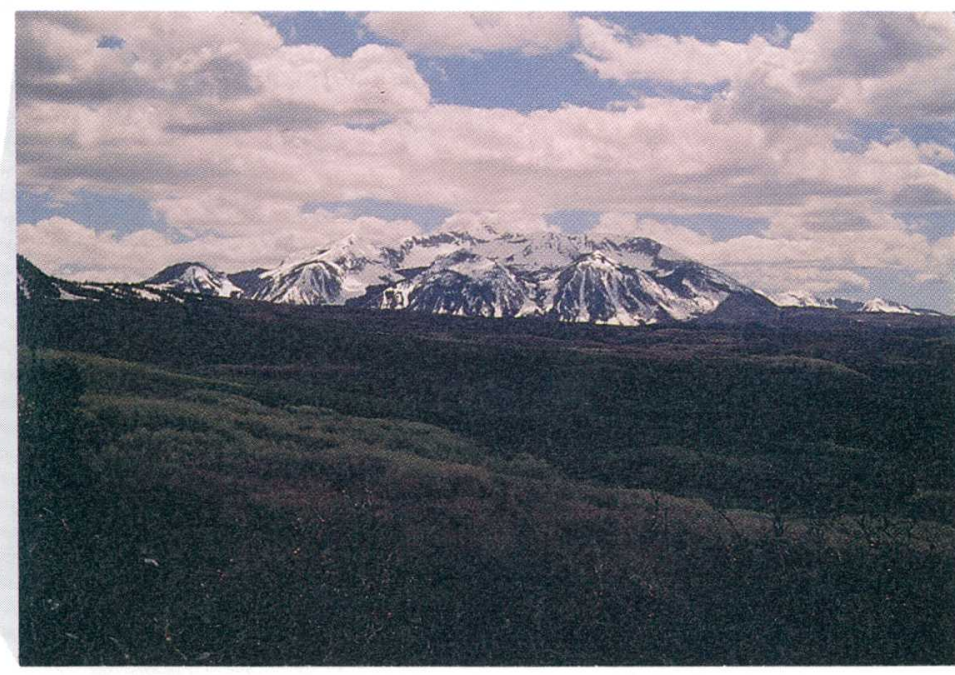

Mount Gunnison and headwaters of the North Fork of the Gunnison River in Area 58. 


\title{
4.0 SURFACE-WATER QUANTITY--Continued \\ 4.2 Streamflow-Gaging Stations
}

\section{Streamflow Information Available for about 350 Locations}

\author{
Continuous records of streamflow, for varying time periods, are available for about \\ 350 locations; data are currently (1984) being obtained at 98 of these locations.
}

\begin{abstract}
About 350 streamflow-gaging stations have been established in Area 58. Most of these stations have been discontinued since they were established, so streamflow records are for varying time periods. Continuous records of streamflow currently (1984) are being obtained at 97 locations, and records of peak flows are being obtained at one additional location. The first station in the area was established during 1894 on the Gunnison River near Grand Junction, Colorado (station 197, fig. 4.2-1), but station 165, Gunnison River below Gunnison Tunnel, Colorado has been operated continuously since October 1903 and has the longest record.
\end{abstract}

For purposes of clarity, only 208 of the approximately 350 streamflow stations are presented in figure 4.2-1. The 208 stations were selected if they currently were active, if they had more than 15 continuous years of record prior to 1953 , or if they had 5 to 15 continuous years of record after 1953 . The criteria were not strictly observed in the selection process; some short-record stations were added to provide better areal coverage for the study area, and some were included because they also were sites for water-quality data collection. General data, such as station name, location, drainage area, and period of record, are listed in section 9.1, "Surface-Water Station Index."

Streamflow data for gaging stations are available from numerous published reports. From 1899 through 1960, streamflow data were published annually in a series of U.S. Geological Survey Water-Supply Papers. These reports, too numerous to detail here, present streamflow data on the basis of river basins or parts of basins. The data for Area 58, the Colorado River drainage basin, are designated as Part 9. All streamflow data prior to 1961 also were compiled into two additional Water-Supply Papers, WSP 1313 (U.S. Geological Survey, 1954) for data through the 1950 water year, and WSP 1733 (U.S. Geological Survey, 1964) for the 1951-60 water years. These two volumes generally contain only monthly, annual, and annual peak streamflow data. The numbers of the previously published annual Water-Supply Papers, which contain daily streamflow data, also are listed in those two reports.

From 1961-70, the annual Water-Supply Papers were replaced by two 5-year Water-Supply Papers, WSP 1924 (U.S. Geological Survey, 1970) for 1961-65 and WSP 2124 (U.S. Geological Survey, 1973) for 1966-70. These two volumes contain daily and other streamflow data. From 1961 to 1970 , streamflow data, on a statewide basis, also were published annually in a series of interim reports, "Surface-Water Records of Colorado." Beginning in 1971, streamflow data were no longer published in the Water-Supply Paper series but only in annual statewide reports, "Water Resources Data for Colorado." This last series of reports is available on microfiche, or sometimes bound volumes, from the National Technical Information Service, U.S. Department of Commerce, 5285 Port Royal Road, Springfield, VA 22161.

Finally, nearly all streamflow data including daily, monthly, annual, and annual peak data are available from computer storage in WATSTORE, described in Section 8.3. Additional information regarding computer retrieval of streamflow data, published reports, or other streamflow-gaging station data is available from the U.S. Geological Survey at the address listed in the front of this report. Much useful information for the operation of a streamflow-gaging station and the computation of streamflow records is presented by Rantz and others (1982). 


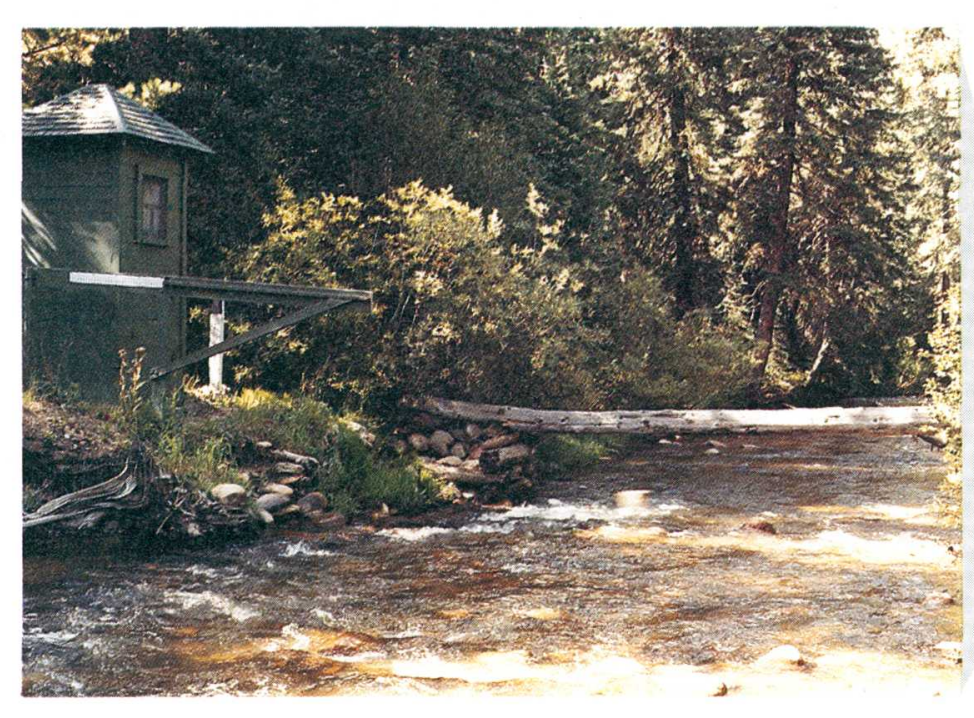

Station 11, Ranch Creek near Fraser, Colorado.

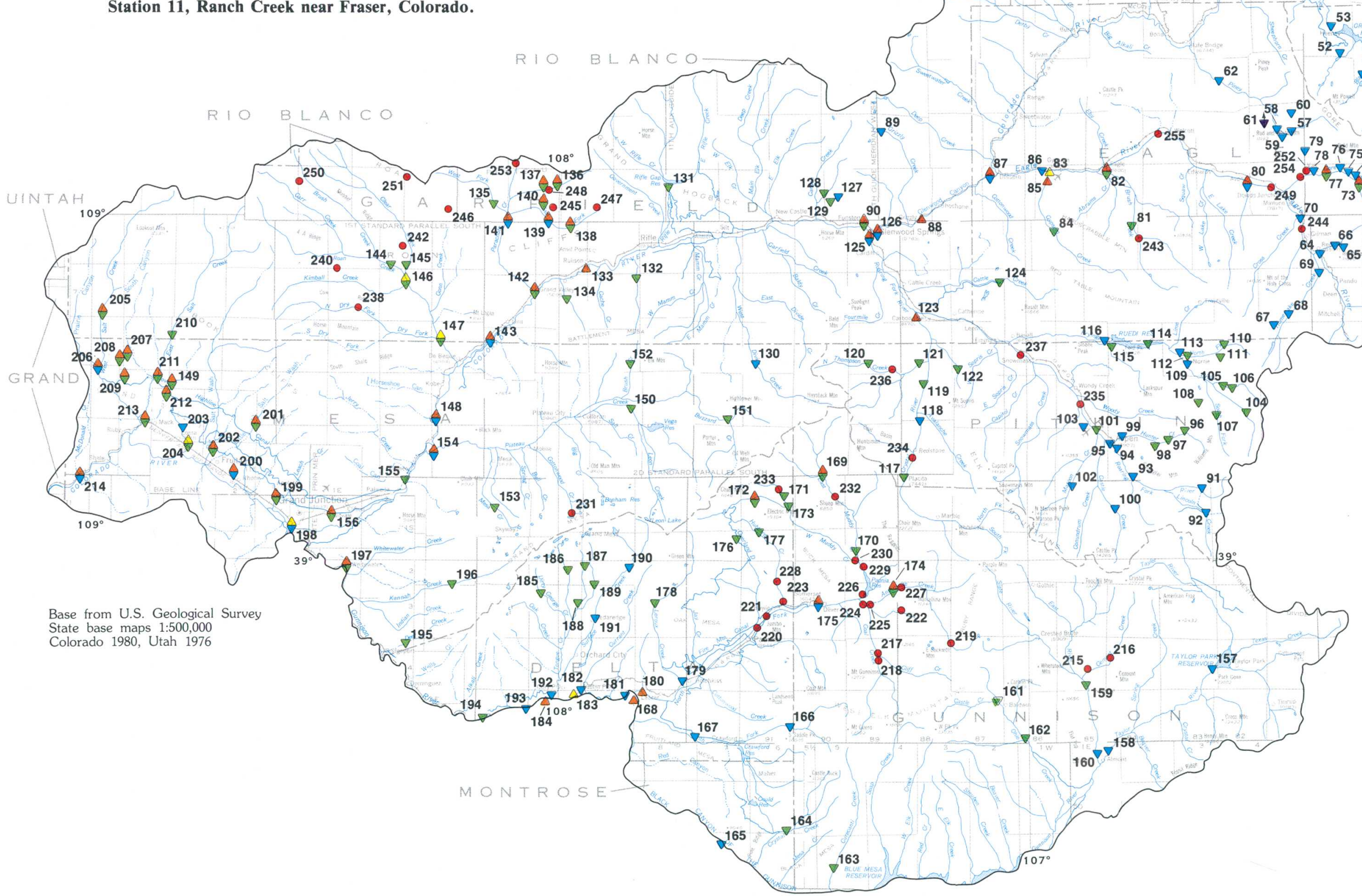

Explanation

$\checkmark \quad$ Active streamflow-gaging station

Inactive streamflow-gaging station

Active water-quality statio

$\triangle \quad$ Inactive water-quality station

- Miscellaneous water-quality

+ Active peak-flow station

150 Station number

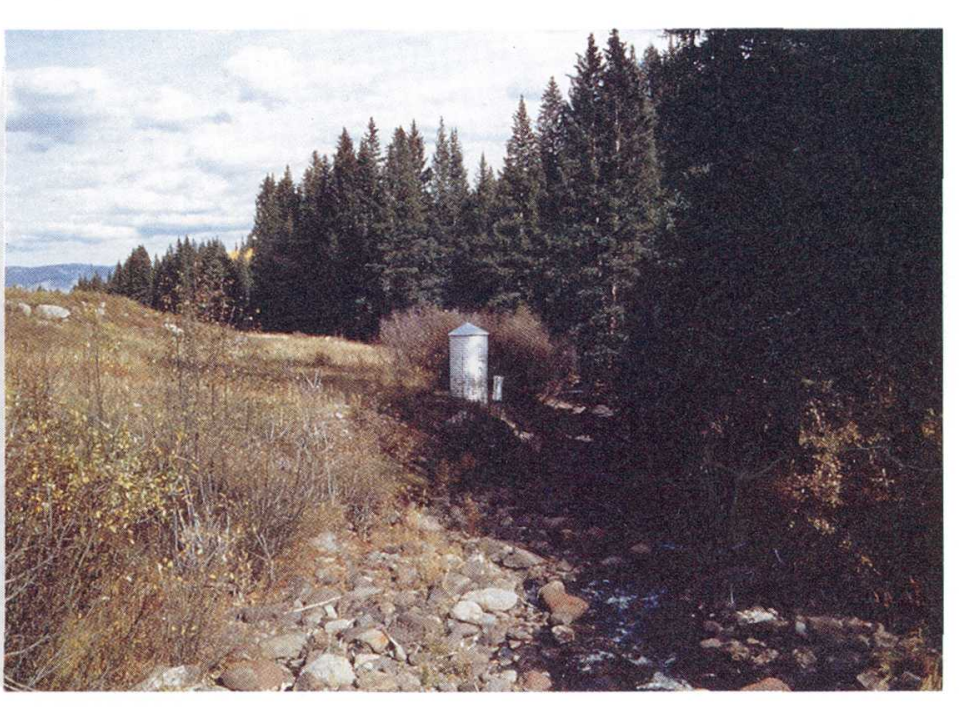

Station 172, Cow Creek near Paonia, Colorado. 


\title{
4.0 SURFACE-WATER QUANTITY--Continued 4.3 Streamflow Sources
}

\section{Most Streamflow Results from Snowmelt}

\author{
Most annual streamflow in Area 58 results from snowmelt during spring and \\ early summer; thunderstorms may be a primary source of streamflow in plateau areas.
}

Nine streamflow stations (fig. 4.3-1) were selected for analysis of streamflow characteristics in Area 58. These stations were selected to illustrate both the differences and similarities in streamflow with respect to time and space. Three stations $(28,125$, and 166 , fig. 4.3-2) are on perennial tributaries of the Colorado River; their streamflow is derived primarily from snowmelt runoff. These three stations are widely spaced and encompass a wide range of drainage-area conditions. One station (206, fig. 4.3-2) is on an ephemeral tributary of the Colorado River in an area where rainfall runoff usually is the primary source of streamflow. Two stations (29 and 204, fig. 4.3-2) illustrate the effect of man's activities on streamflow. Streamflow at station 29 is regulated by a reservoir, and streamflow at station 204 is derived primarily from return flow from irrigated cropland. Streamflow at a large percentage of all stations in the area is affected to some degree by diversion and regulation, but stations 29 and 204 illustrate a significant effect from these activities. Finally, three stations $(3,20$, and 87 , fig. 4.3-2) are included in the analysis to show the changing, downstream-flow characteristics in the area. Station 3, on the Colorado River, is near the mountain headwaters, and the streamflow shows little effect from man's activities. Streamflow at the next two stations (20 and 87) on the Colorado River is affected increasingly by diversion and regulation.

Much of Area 58 consists of a series of mountain ranges that have elevations between about 9,000 and 13,000 feet and that are drained by numerous perennial streams. Deep snowpacks accumulate in these mountains during winter and early spring, and because precipitation generally increases with elevation, the depth of the snowpacks also generally increases with elevation. However, wind, steepness of slope, and lack of vegetation affect the normal accumulation of snow considerably at elevations above treeline $(11,000$ to 12,000 feet).

Melting of these snowpacks during spring and early summer produces most streamflow in the area. Snowmelt generally begins during early spring at lower elevations and as temperatures increase, snowmelt occurs at higher and higher elevations. Snowmelt is greatest during May, June, and July, when the deeper, higher-elevation snowpacks melt. The percent of the average annual streamflow during May, June, and July at stations where snowmelt is the primary source of streamflow varies from about 79 percent at station 3, Colorado River below
Baker Gulch near Grand Lake, Colorado, to about 61 percent at station 125, Roaring Fork River at Glenwood Springs, Colorado (fig. 4.3-2). Generally, stations on streams that have smaller drainage basins and that are closer to the mountainous headwaters have a greater percentage of their annual streamflow during the three primary snowmelt months than stations on streams that have larger drainage basins and that are more distant from the headwaters.

Streamflow in a small part of Area 58 is not derived primarily from snowmelt but rather from rainfall or sometimes both rainfall and snowmelt. This area generally is the plateau area north of the Colorado River and downstream from the vicinity of Grand Valley, Colorado (fig. 4.3-1). The elevation of mountains in this area is about 8,500 feet or less, so snowpacks accumulating here are not as deep as elsewhere; therefore, streamflow in this area often is derived from runoff resulting from summer thunderstorms.

The graph for station 206, West Salt Creek near Mack, Colorado (fig. 4.3-2), illustrates the annual distribution of streamflow in this area. About 45 percent of the average annual streamflow at station 206 occurs during August, September, and October, whereas at stations where snowmelt predominates, the percentage of the average annual streamflow during those 3 months is about 12 to 18 percent.

Streamflow at station 29, Williams Fork below Williams Fork Reservoir, Colorado, shows the effect of streamflow regulation by reservoirs. Comparison of the graphs (fig. 4.3-2) for this station with those of station 28, Williams Fork near Parshall, Colorado, shows a significant change in streamflow characteristics caused by reservoir storage.

Streamflow at station 204, Reed Wash near Loma, Colorado, is derived mostly from return flow and wastewater from lands irrigated with water from the Government Highline and Grand Valley Canals. Streamflow in Reed Wash is very uniform during the irrigation season from May to October. Although distribution of streamflow at stations 204 and 206 seems very similar from May to October, there is a considerable difference in the drainage area of the two basins and a very large difference in the average annual streamflow at the two stations (figs. 4.3-1 and 4.3-2). 

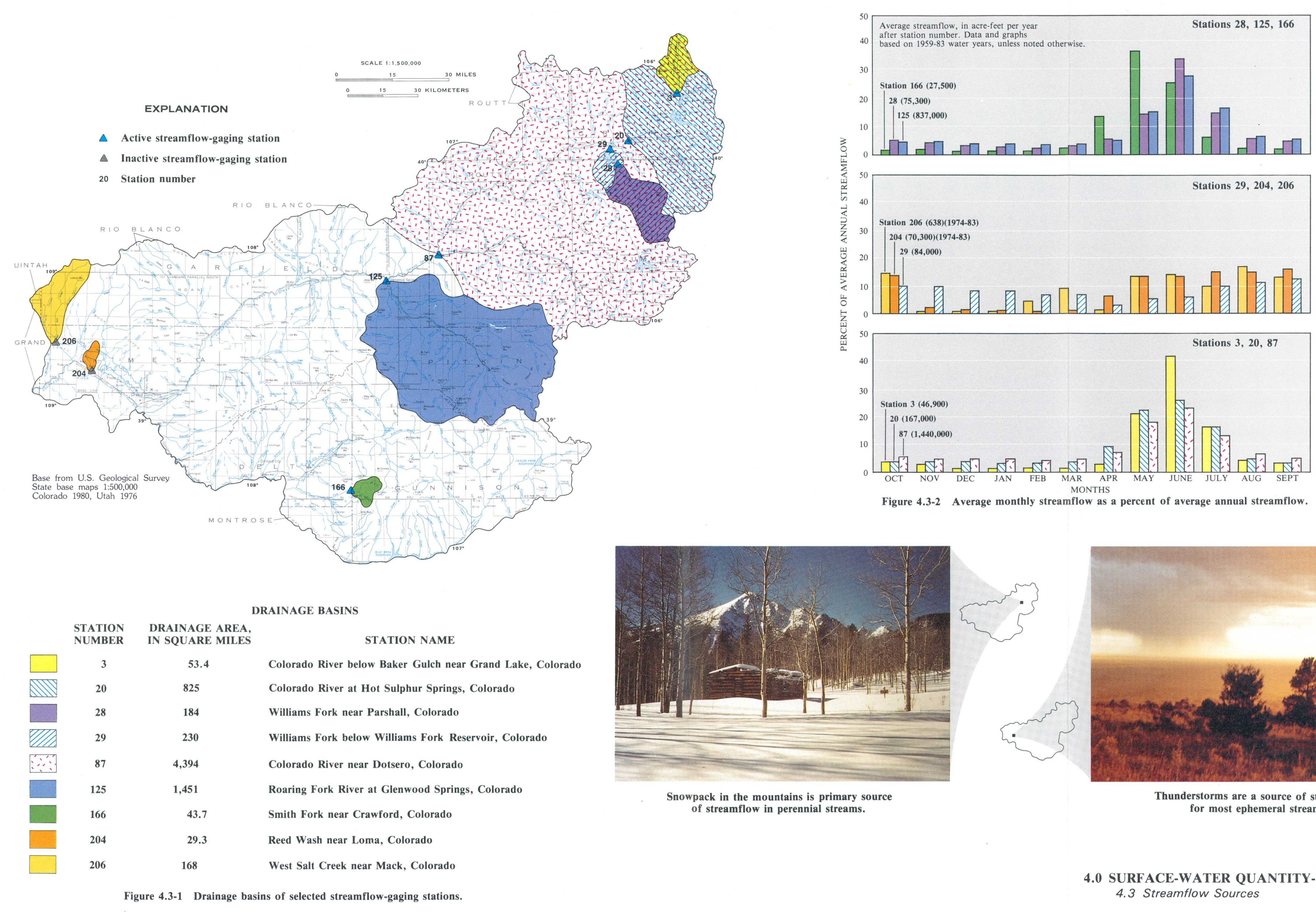

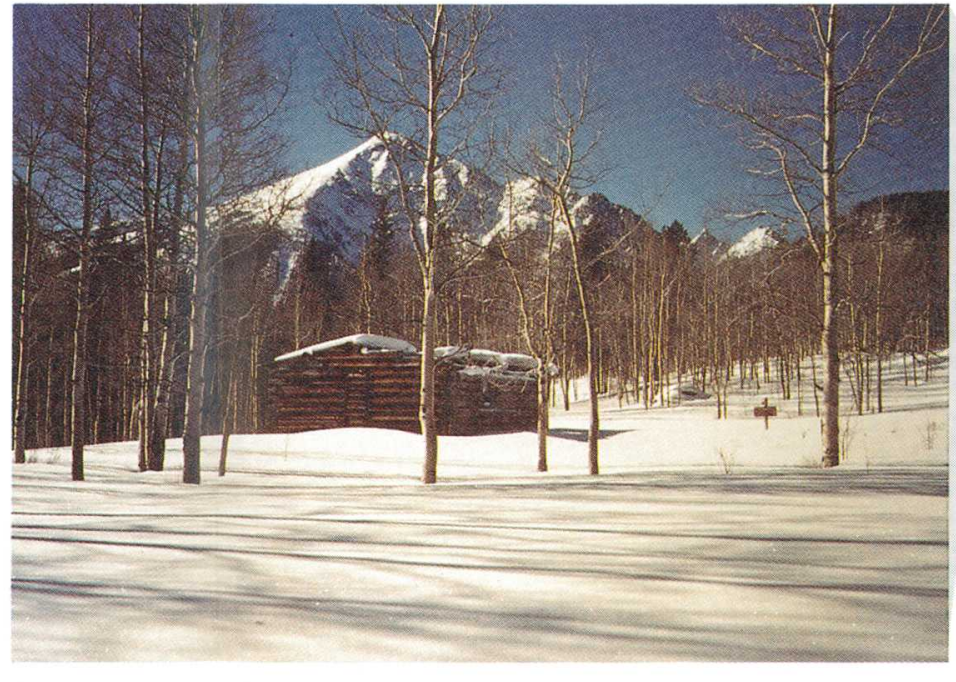
Snowpack in the mountains is primary source
of streamflow in perennial streams.

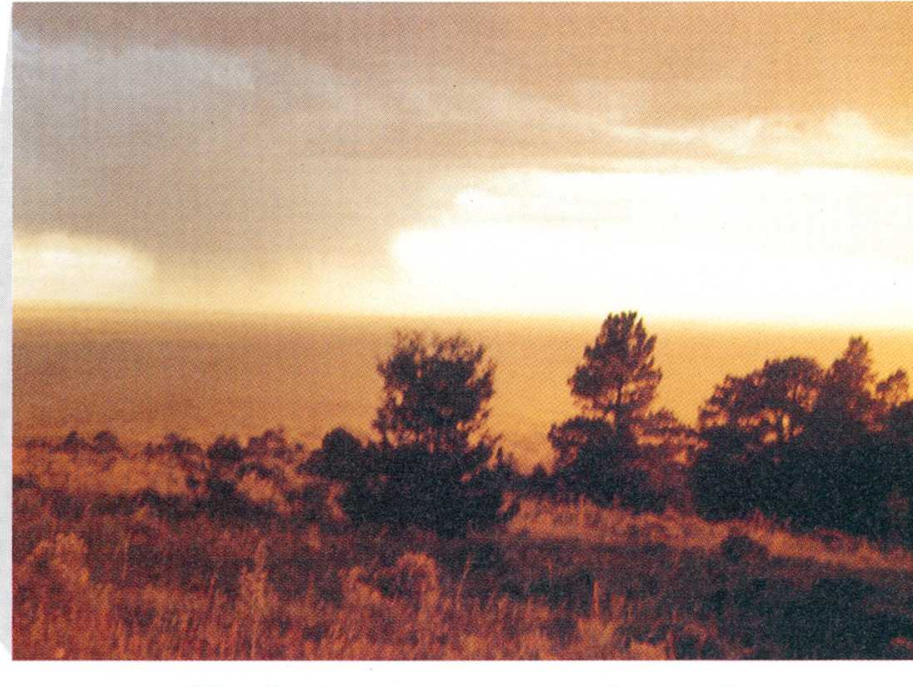

Thunderstorms are a source of streamflow for most ephemeral streams. 


\title{
4.0 SURFACE-WATER QUANTITY--Continued \\ 4.4 Streamflow Variability
}

\section{Streamflow has Marked Seasonal and Annual Variability}

\author{
Streamflow is highly variable, both within any given \\ year and between individual years.
}

Daily streamflow hydrographs for three selected streamflow stations $(28,125$, and 206 , fig. 4.4-1) are shown in figure 4.4-2. Hydrographs are illustrated for the years of maximum and minimum annual streamflow for the 1959-83 water years, except for station 206, for which streamflow records are available only for the 1974-83 water years. These hydrographs (fig. 4.4-2) illustrate streamflow variability.

The hydrographs for station 125, Roaring Fork River at Glenwood Springs, Colorado, and station 28, Williams Fork near Parshall, Colorado, show the variability of snowmelt runoff. The within-year increase in average daily streamflows at the two stations varies from an eightfold increase during 1977 at station 125 to a sixtyfold increase during 1983 at station 28. Magnitudes of these increases at other stations in the area probably are within that range. Generally, the seasonal increase in streamflow due to snowmelt is more significant in smaller drainage basins near the mountainous sources and during years with average or above average snowpacks. The magnitude of seasonal streamflow variability depicted by the hydrographs (fig. 4.4-2) is diminished somewhat because of the logarithmic scale.
Variation in streamflow derived from snowmelt from one year to another also is shown in figure 4.4-2. Annual precipitation amounts, which affect the depth and water content of snowpacks, can vary considerably in the area; hence, the resultant amount of streamflow from snowmelt also varies.

Seasonal and annual variations in streamflow in ephemeral streams are depicted by the hydrographs for station 206, West Salt Creek near Mack, Colorado (fig. 4.4-2). Streamflow at this station, resulting primarily from rainfall runoff, is much more variable, both within and between years, than streamflow at stations 28 and 125 . Streamflow on ephemeral streams, such as West Salt Creek, is quite discontinuous; the time of flow can be as little as a few hours. Streamflow at station 206 is even more variable than depicted by the hydrographs of average daily flow. For example, there was no flow at this station on July 21,1983 , but on July 22 , the daily flow was 65 cubic feet per second. However, the maximum streamflow on July 22 was 634 cubic feet per second, nearly 10 times greater than the daily flow. On perennial snowmelt streams, the maximum streamflow generally is only about 10 to 20 percent greater than the maximum daily streamflow. 

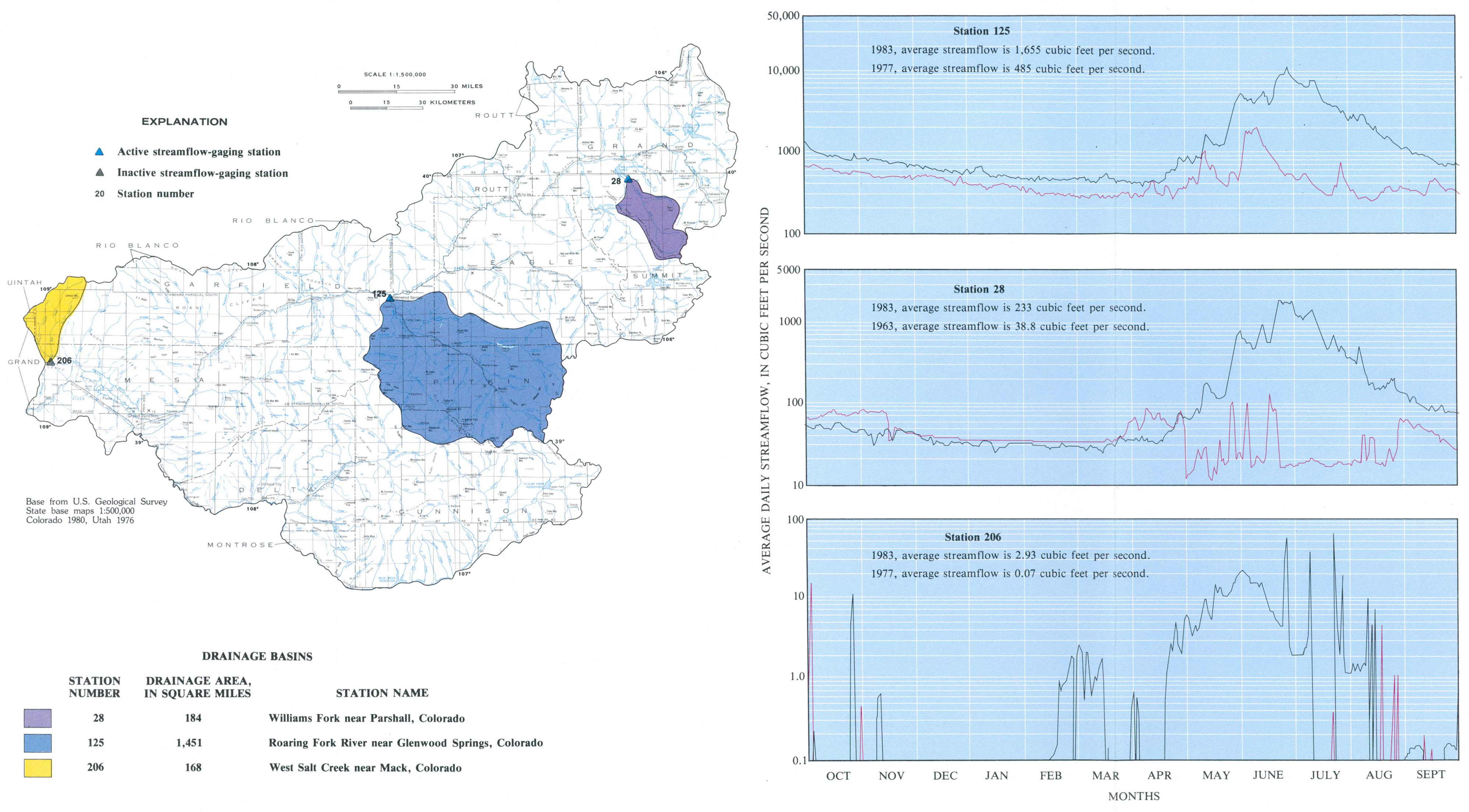

Figure 4.4-1 Drainage basins of selected streamflow-gaging stations.

Figure 4.4-2 Daily streamflow by month for the years of maximum and minimum streamflow for selected streamflow-gaging stations. 


\title{
4.0 SURFACE-WATER QUANTITY--Continued 4.5 Streamflow Duration
}

\section{Flow-Duration Curves are Similarly Shaped for Most Perennial Streams}

\author{
Streamflow in most perennial streams is derived from snowmelt and \\ is well sustained, hence, flow-duration curves are similarly shaped \\ with flattened slopes at the upper and lower end.
}

Flow-duration curves for nine streamflow stations (fig. 4.5-1) are illustrated in figure 4.5-2; these stations are briefly described in section 4.3, "Streamflow Sources." The shape and slope of a flow-duration curve reflect the climatic, hydrologic, and geologic characteristics of a drainage basin (Searcy, 1959, p. 21-22). Streamflow regulation also may affect the flowduration characteristics of a stream.

Flow-duration curves for stations on perennial streams whose flow is derived primarily from snowmelt and not totally regulated (stations 125, 28, 166, 87, 20, and 13, fig. 4.5-2) are somewhat similar in shape, with flattened slopes at the upper and lower ends. Streams whose high flows result from snowmelt tend to have flowduration curves with a flat slope on the upper end; the flat slope on the lower end indicates perennial storage in the basin (Searcy, 1959, p. 22). High flows at these six stations result from snowmelt over an extended period of time-thus the flattened upper end of the curves.

Perennial storage in a basin helps provide a sustained base flow. This storage generally may be in three forms in the area: (1) Alluvial aquifers; (2) perennial snowfields; and (3) manmade reservoirs. The greater precipitation in the basins upstream from the six snowmelt-affected stations and the extended snowmeltrunoff period provide recharge to the alluvium capable of sustaining streamflow during the winter months as opposed to the situation illustrated at station 206 . Gradual melting of perennial snowfields also helps sustain flow during late summer and fall. Finally reservoir releases may help sustain streamflow throughout the year at some locations. For the six stations listed above, streamflow duration is significantly affected by reservoir releases only at stations 20,87 , and 125 (fig. 4.5-2).

Generally, the variation between high and low flows decreases in a downstream direction; this is especially evident by comparing flow-duration curves for the three stations on the Colorado River (stations 3,20 , and 87 ). Station 3, Colorado River below Baker Gulch near Grand Lake, Colorado, has basically natural flow and minor amounts of diversion upstream. Downstream from station 3 to station 87, Colorado River near Dotsero, Colorado, there is increasing storage of streamflow in reservoirs, larger variation in depth of snowpack and time of snowmelt, greater amounts of ground-water storage and flow from ground water, and more streamflow diversion and return flow. Thus, flow-duration curves for sta- tions 3,20 , and 87 indicate increasingly less variability in streamflow.

Station 206, West Salt Creek near Mack, Colorado, has a flow-duration curve that has a steep slope throughout (fig. 4.5-2), indicating that flow on this stream is quite variable and is derived primarily from surface runoff (Searcy, 1959, p. 22). Surface- or groundwater storage is unavailable in the basin to equalize the flow because: (1) Snowpacks, a form of surface-water storage, having a significant water content usually do not accumulate during winter in this drier, lower elevation part of the area; (2) precipitation generally is insufficient to provide recharge to alluvium in the stream valleys in a quantity that is capable of sustaining flow between periods of precipitation; and (3) bedrock aquifers either are not present in the basin upstream of the gage, or if present, are not contributing to the streamflow. Thus, flow in this ephermeral stream is not sustained, and periods of no flow are common.

Streamflows at stations 29 and 204 are affected significantly by the activities of man, evident from the very differently shaped flow-duration curves for these two stations (fig. 4.5-2). Station 204, Reed Wash near Loma, Colorado, is in an area where ephemeral streams are common; however, this station has a curve very different in shape from station 206, which is nearby. The flattened lower end probably is a result of extensive recharge to the alluvium by irrigation, which provides a sustained low flow. Also note the much greater streamflow at station 204 in comparison to station 206, which has a much greater drainage area. The flattened upper end is not the result of snowmelt, but of a long period of high flow derived from return flow from irrigated areas upstream of station 204.

Streamflow at station 29, Williams Fork below Williams Fork Reservoir, Colorado, is virtually controlled by man. The flow-duration curve for this station shows that mid-range streamflows have a greater duration and that high- and low-range streamflows have a lesser duration than at station 28, Williams Fork near Parshall, Colorado, just upstream from the reservoir.

Flow-duration data for other streamflow stations in the area and for other time periods are available in reports by Petsch (1980 and 1983) and in a report by Richter and others (1984). Flow-duration data also are available from computer storage in WATSTORE, described in section 8.3. 


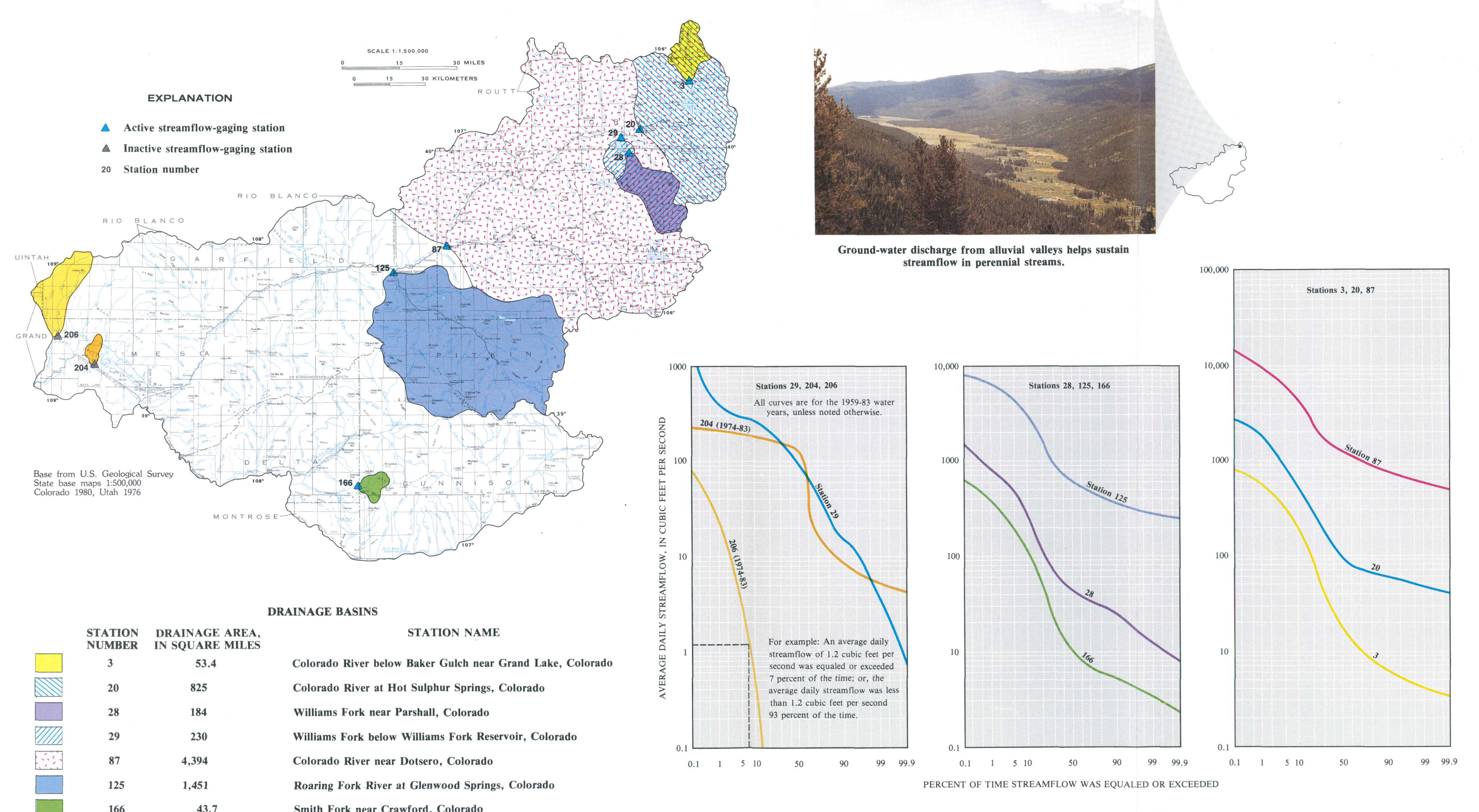

Roaring Fork River at Glenwood Springs, Colorad

Smith Fork near Crawford, Colorado

Reed Wash near Loma, Colorado

Figure 4.5-2 Streamflow-duration curves for selected streamflow-gaging stations.

West Salt Creek near Mack, Colorado 


\title{
4.0 SURFACE-WATER QUANTITY--Continued 4.6 Floodflow and Flood-Prone Areas
}

\section{Most Annual Floods Result from Snowmelt}

\author{
Floodflows in Area 58 usually are a result of snowmelt, \\ but flooding generally is not a severe problem.
}

\begin{abstract}
Streamflow on most perennial streams primarily results from snowmelt, and most annual floods on these streams occur during the snowmelt period. Although the magnitude of these floods can be quite large (see fig. 4.4-2), exceptionally large snowmelt floods that could cause severe flooding are very uncommon. Because of the annual nature of snowmelt floods, most stream channels are capable of carrying these annual snowmelt floods without extensive bank overflow or significant flooding. Reservoir storage, transmountain diversions, and local diversions for irrigation also provide some reduction in the magnitude of the annual snowmelt floods.
\end{abstract}

Floods in perennial mountain streams resulting from rainfall generally are less than snowmelt-caused floods. This is evident from a compilation of data of annual snowmelt and rain fall floodflows at selected streamflow-gaging stations in Colorado (Elliott and others, 1982). However, streams with significant parts of their drainage basins at lower elevations, generally below about 7,500 feet, are increasingly subject to annual floods resulting from rainfall (Jarrett and Costa, 1982). Ephemeral streams in the area usually are at lower elevations and almost always have annual floods resulting from rainfall, often derived from locally intense thunderstorms.

Floodflow often is graphically described in terms of a floodflow-frequency curve. Floodflow-frequency information is necessary for the design of reservoirs and flood-control structures and is useful in water-resources planning.

Floodflow-frequency curves for four selected streamflowgaging stations (fig. 4.6-1) are shown in figure 4.6-2. The curves for perennial streams (stations 20,125 , and 166) are somewhat similar in shape and slope; the positions of the curves are primarily due to the size of the drainage basins for the three stations. However, the curve for station 125, Roaring Fork River at Glenwood Springs, Colorado, has a somewhat flatter slope, indicating less variability in floodflows. Generally, streamflow in the area becomes less variable as the size of drainage basins increases (see section 4.3), and floodflows also tend to be less variable on larger basins.

The floodflow-frequency curve for an ephemeral stream, station 206, West Salt Creek near Mack, Colorado, has a steeper slope at the lower end than the other three curves (fig. 4.6-2). Streamflow, including floodflows, generally is more variable on ephemeral streams than on perennial streams in the area. However, the difference in slope between the curve for station
206 and those for the perennial streamflow stations is not as great as the difference in slope between a high-flow frequency curve for an ephemeral stream on the eastern plains of Colorado and curves for perennial mountain streams (D. R. Minges, U.S. Geological Survey, written commun., 1984). The geographic location of station 206 and the adjacent area is more removed from significant moisture sources and has less humidity than the eastern plains of Colorado. Consequently, streamflow-producing thunderstorms in Area 58 probably are of a smaller size and intensity than on the eastern plains. The short period of record at station 206 affects the accuracy with which floods with larger recurrence intervals can be predicted. The slope of the curve for this station could change considerably with additional years of streamflow record.

Because of the potential destructive force of floods, floodflows are a common topic of hydrologic studies. Floodflows through the 1962 water year, for streams in the entire Colorado River basin including Area 58, have been compiled in a report by Patterson and Somers (1966). This report also presents graphical relations, based on streamflow records, to determine the magnitude of floods having recurrence intervals between 1.1 and 50 years on most streams in the Colorado River basin (Patterson and Somers, 1966, p. 1-28). More recently, McCain and Jarrett (1976) presented relations for estimating magnitudes of floods on natural-flow streams in Colorado that had recurrence intervals of $1,50,100$, and 500 years. The national importance of flood studies also has resulted in a standard, nationwide method for the determination of magnitude and frequency of floods (U.S. Water Resources Council, 1982). Finally, a study currently (1984) is being conducted to develop more reliable methods of determining flood magnitude and frequency in the foothills region of Colorado. The work is described in McCain and Ebling (1979) and Jarret and Costa (1982).

In addition, the National Flood Insurance Act of 1968 and the Flood Disaster Protection Act of 1973 established programs for identifying towns and stream reaches subject to flooding. Many of these potentially flood-prone areas have been delineated on 7 1/2-minute topographic maps. Since 1970, the delineation of the flood-prone areas has been based on floods that have a 100-year recurrence interval, or a 1-percent exceedence probability. The 7 1/2-minute topographic maps that have been completed for the report area are shown in figure 4.6-1. These maps are available from the U.S. Geological Survey at the address in the front of this report. 

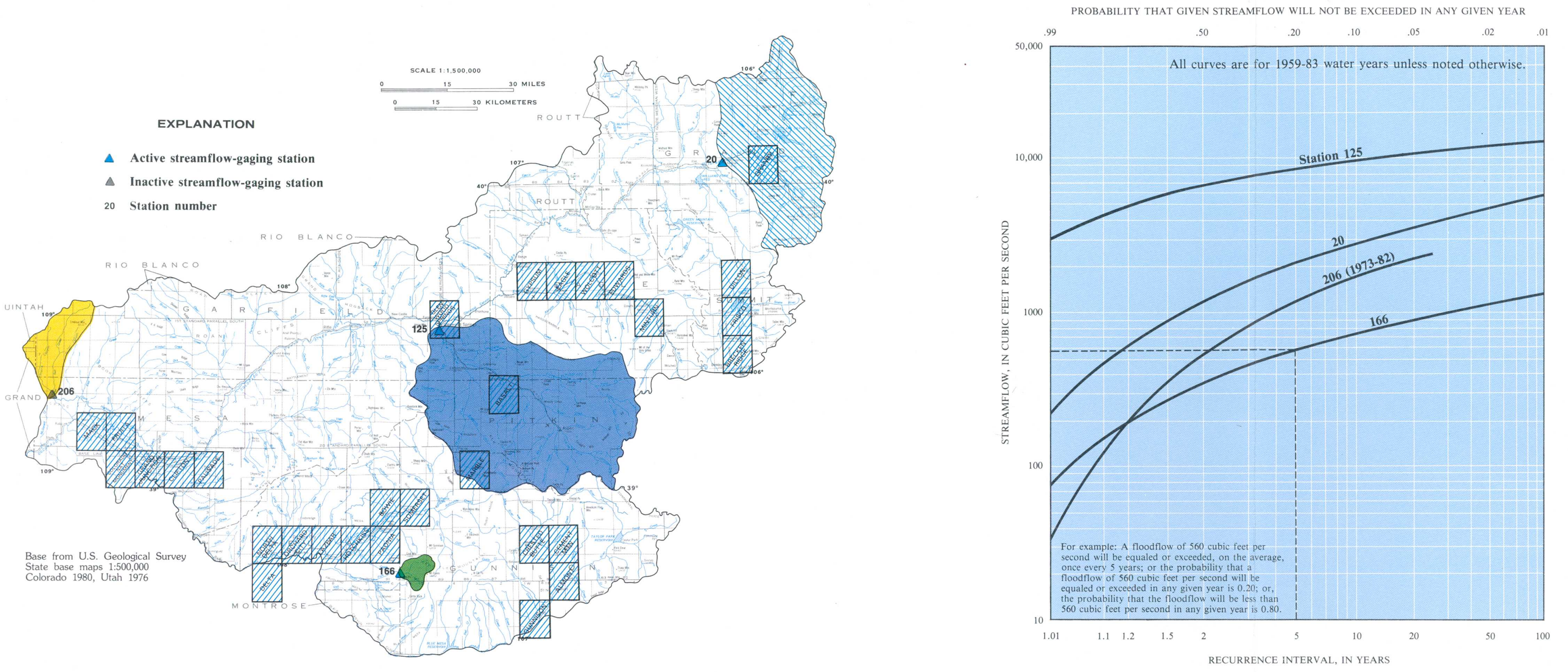

Figure 4.6-2 Floodflow-frequency curves for selected streamflow-gaging stations.

Flood-prone area map and name

\begin{tabular}{|c|c|c|}
\hline $\begin{array}{l}\text { STATION } \\
\text { NUMBER }\end{array}$ & $\begin{array}{l}\text { DRAINAGE AREA, } \\
\text { IN SQUARE MILES }\end{array}$ & STATION NAME \\
\hline 20 & 825 & Colorado River at Hot Sulphur Springs, Colorado \\
\hline 125 & 1,451 & Roaring Fork River at Glenwood Springs, Colorado \\
\hline 166 & 43.7 & Smith Fork near Crawford, Colorado \\
\hline 206 & 168 & West Salt Creek near Mack, Colorado \\
\hline
\end{tabular}

Figure 4.6-1 Drainage basins of selected streamflow-gaging stations and locations for flood-prone area maps.

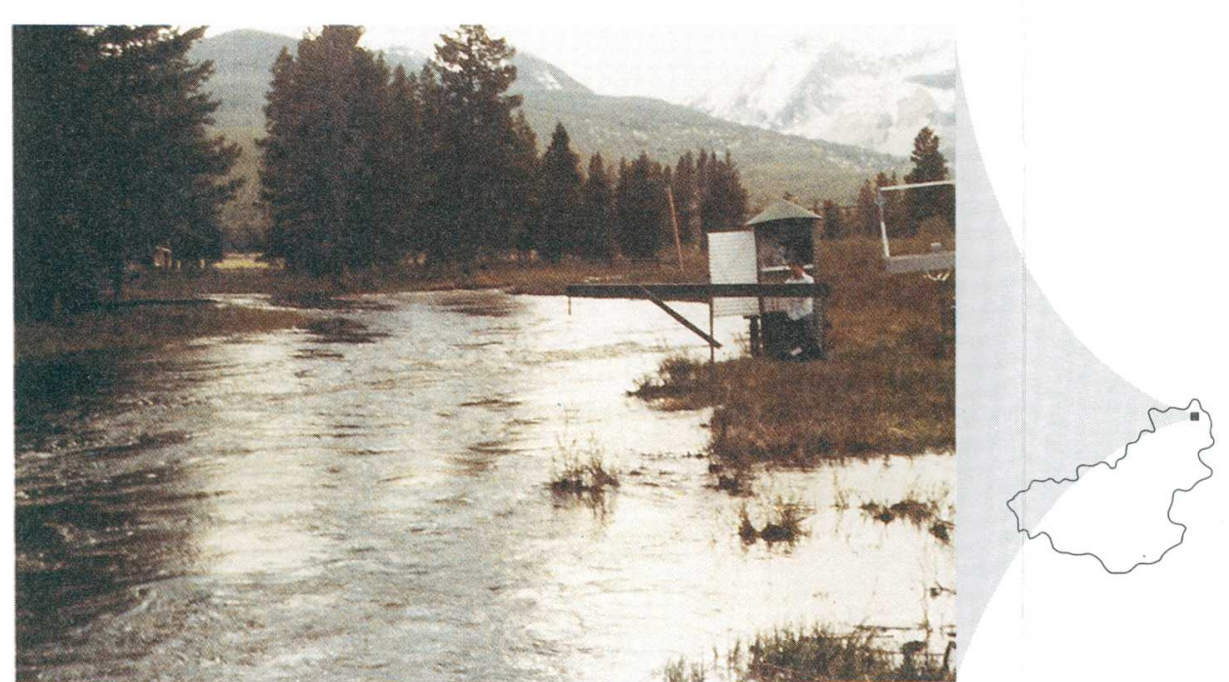

Annual snowmelt flood at Station 3, Colorado River below Baker Gulch near Grand Lake, Colorado.
(compare with photograph in section 4.7)
4.0 SURFACE-WATER QUANTITY--Continued 4.6 Floodflow and Flood-Prone Areas 


\title{
4.0 SURFACE-WATER QUANTITY--Continued 4.7 Low Flow
}

\section{Low Flows on Perennial Streams Sustained by Flows from Ground Water}

\author{
Low flows on perennial streams are sustained primarily by flows from \\ ground water; gradual melting of perpetual snowfields and reservoir \\ releases also augment low flows on some streams.
}

Low flows on perennial streams in the area are sustained primarily by three sources: (1) Flows from ground water; (2) gradual melting of perpetual snowfields during late summer and fall; and (3) reservoir releases. The first of these sources, flows from ground water, is the most significant. Flows from ground water help sustain streamflow on practically every perennial stream throughout the year. Gradual melting of perpetual snowfields provides a continued source of streamflow during late summer and fall, but this melting virtually ceases during winter. Reservoir releases also augment low flows, primarily on the Colorado and Gunnison Rivers and on some reaches of a few tributary streams on which reservoirs with significant storage capacity have been constructed.

Low flow often is graphically described in terms of a low-flow frequency curve. Low-flow frequency information is helpful in evaluating a stream for water supply or indicating its waste-dilution capacity. A common low-flow statistic used in waste-water-discharge permits is the 7-day, 10-year low flow.

Low-flow frequency curves for three streamflow-gaging stations (fig. 4.7-1) are shown in figure 4.7-2. Streamflows at these stations, which encompass a variety of streamflow conditions, are representative of flow conditions on perennial streams throughout the area. The frequency curves, because of their relatively flat slopes, show that low flows at these stations, and generally on most perennial streams, are well sus- tained. The steeper slopes for the 1- and 7-day curves for station 166, Smith Fork near Crawford, Colorado, may be the result of diversion upstream from the station. The diversion amounts may be greater for shorter periods than for longer periods.

Ephemeral streams have extended periods of no flow and cannot be meaningfully analyzed for low-flow frequency. Thus, curves for stations on ephemeral streams, such as station 206, West Salt Creek near Mack, Colorado, are not presented. For each of the 10 years of record at station 206, at least 30 consecutive days of no flow were recorded.

The low-flow frequency curves presented in figure 4.7-2 illustrate that low flows generally are well sustained in most of Area 58. For this reason, a uniform time period (1959-83 water years) during which conditions affecting streamflow did not change significantly, was selected for presentation. Low-flow frequency curves for other periods may show a somewhat different low flow for a given recurrence interval; however, the wellsustained nature of low flow would continue to be evident. According to Riggs (1972, p. 6), 20 or more years of streamflow record are desirable to define the 20-year recurrence interval minimum annual flow adequately. Additional low-flow data for streamflow stations in the area are available in reports by Petsch (1980 and 1983) and by Richter and others (1984). Low-flow frequency data also are available from computer storage in WATSTORE, described in section 8.3 . 

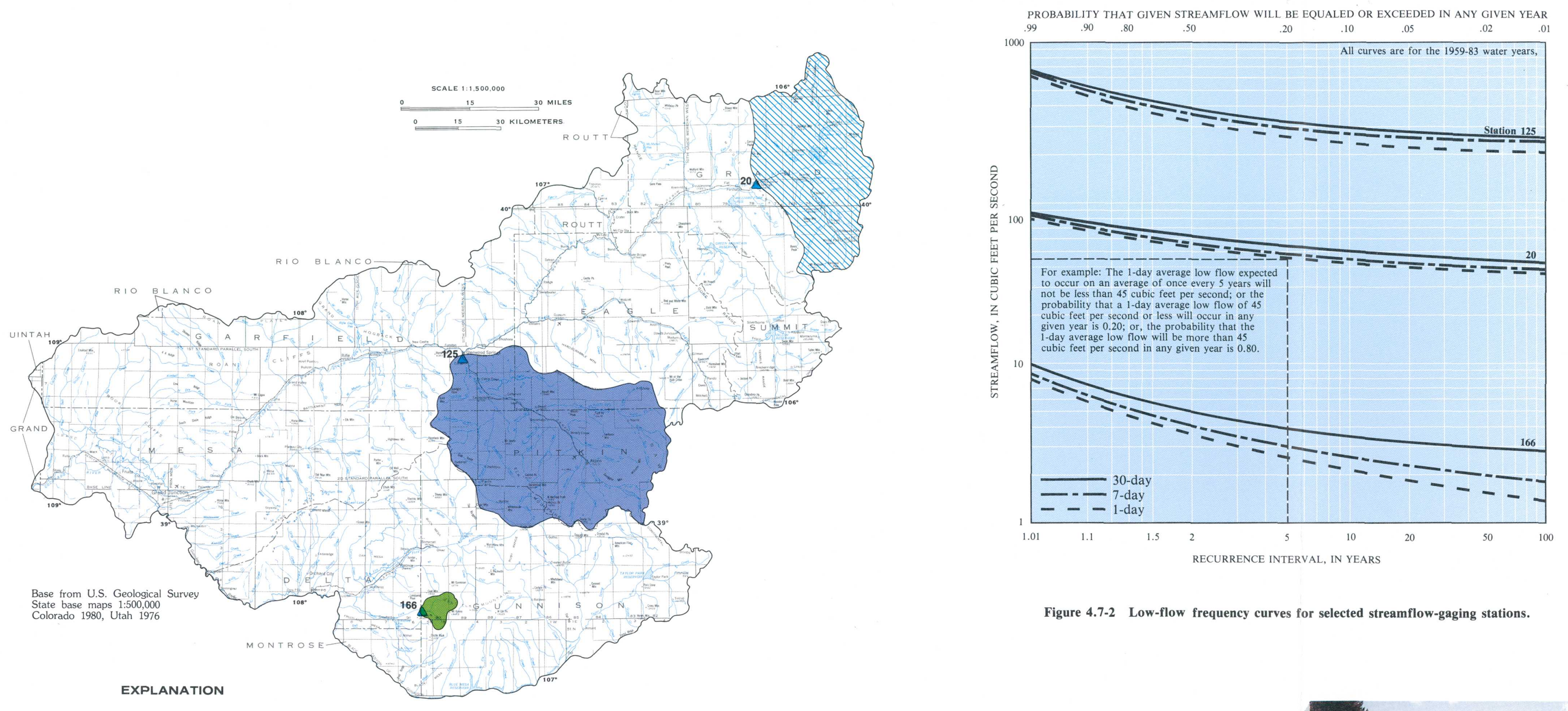

Figure 4.7-2 Low-flow frequency curves for selected streamflow-gaging stations.

$\Delta^{20} \quad$ Active streamflow-gaging station and number

DRAINAGE BASINS $\begin{array}{ll}\text { STATION } & \text { DRAINAGE AREA, } \\ \text { NUMBER } & \text { IN SQUARE MILES }\end{array}$

\section{STATION NAME}

\begin{tabular}{lrrl}
\hline 120 & 825 & Colorado River at Hot Sulphur Springs, Colorado \\
\hline & 125 & 1,431 & Roaring Fork River at Glenwood Springs, Colorado \\
\hline & 166 & 43.7 & Smith Fork near Crawford, Colorado
\end{tabular}

Figure 4.7-1 Drainage basins of selected streamflow-gaging stations.

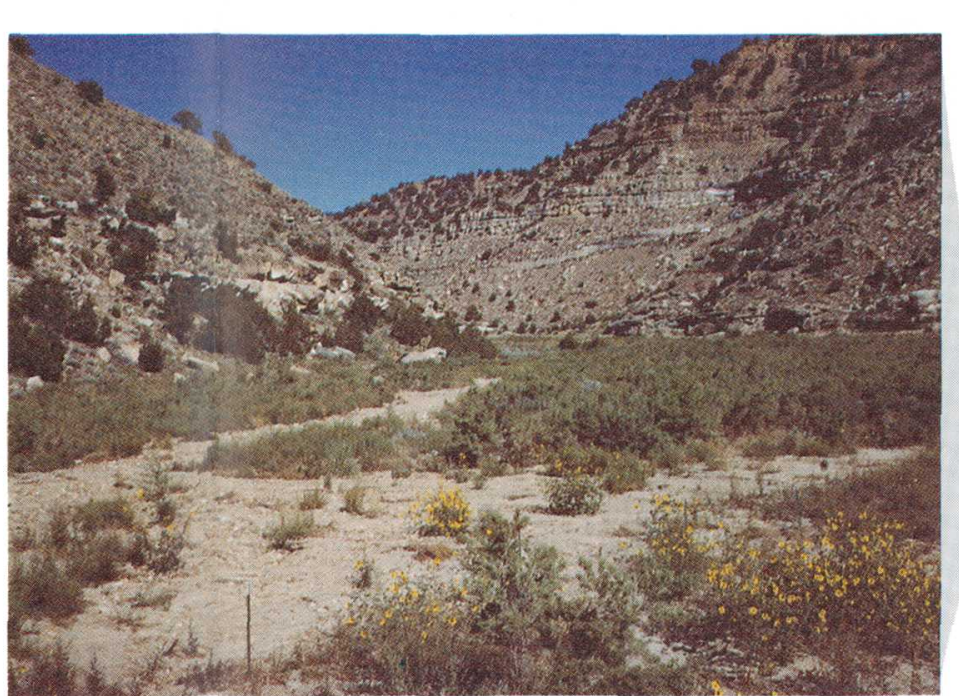

Ephemeral streams have extended periods of no flow.
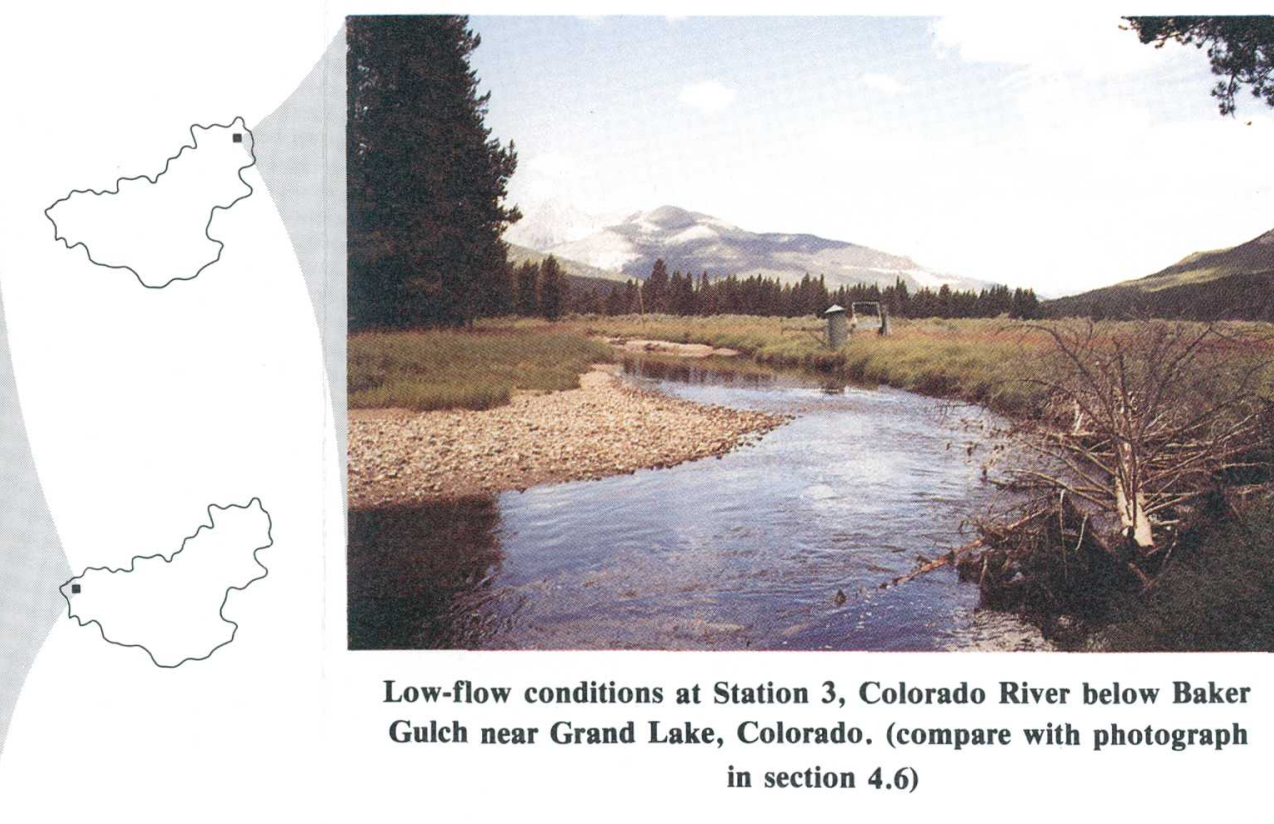

Low-flow conditions at Station 3, Colorado River below Baker Gulch near Grand Lake, Colorado. (compare with photograph in section 4.6)

4.0 SURFACE-WATER QUANTITY--Continued 4.7 Low Flow 


\title{
4.0 SURFACE-WATER QUANTITY--Continued \\ 4.8 Estimating Streamflow Characteristics
}

\section{Streamflow Characteristics can be Estimated}

\author{
Techniques are available to estimate peak, average annual, and other \\ streamflow characteristics for natural-flow perennial streams.
}

\begin{abstract}
During water-resources studies and management activities, knowledge of streamflow characteristics, such as the peak or average annual flow, often is needed at a site where no streamflow records are available. For this purpose, relations have been developed from which streamflow characteristics can be estimated at ungaged sites. These relations are developed on a regional basis by relating individual streamflow characteristics at many gaged sites to one or more physical basin characteristics in the form of multiple regression equations. Then, these equations can be used to estimate a flow characteristic at an ungaged site on the basis of the physical characteristics of the basin. Some basin characteristics commonly used in these estimating equations are drainage area, precipitation, elevation, slope, temperature, and type and amount of vegetation.
\end{abstract}

A study relating many streamflow characteristics to basin characteristics for western Colorado recently has been completed by the U.S. Geological Survey in cooperation with the U.S. Bureau of Land Management. The study results, including regression equations relating streamflow characteristics to basin characteristics, are contained in the report by Kircher and others (1985). Separate regression equations were developed for different hydrologic regions. The hydrologic regions lying within Area 58 are shown in figure 4.8-1. Equations to estimate the mean annual flow, mean monthly flow, minimum and maximum 7-day flows, and peak flow are presented by Kircher and others (1985) for both gaged and ungaged natural streams in western Colorado. To correctly apply these estimating equations, the user needs to refer to this report; presentation of their procedures is beyond the scope of this chapter.
The most significant variable affecting streamflow relations was determined to be drainage area (Kircher and others, 1985). Other important variables were mean annual precipitation, mean basin elevation, and mean basin slope. All four variables are included in the regression equations. Basin, hydrologic, and climatic character. istics compiled in conjunction with this study are presented in a report by Richter and others (1984).

Earlier regional analyses of streamflow characteristics in relation to basin characteristics for the State of Colorado were completed by Livingston (1970) and McCain and Jarrett (1976). The relations developed in these studies are applicable only to natural-flow perennial streams in Colorado. Equations are presented by Livingston (1970, p. 26-28) to estimate average annual, average monthly, peak, and low flows for perennial moun. tain streams only. The equations for estimating low flow are not considered usable, however, because of very large standard errors of estimate (Livingston, 1970, p. 29-30). Some of the techniques for estimating peak flows presented by Livingston (1970) are superseded by techniques presented by McCain and Jarrett (1976). The regression equations presented in the report by Kircher and others (1985) are now considered to be the best available. Additional references that may be useful in analysis of streamflow characteristics include: Moore (1968); Patterson and Somers (1966); Riggs (1968a, 1968b, 1969, 1972, and 1973); Riggs and Moore (1965); and Thomas and Benson (1970). 


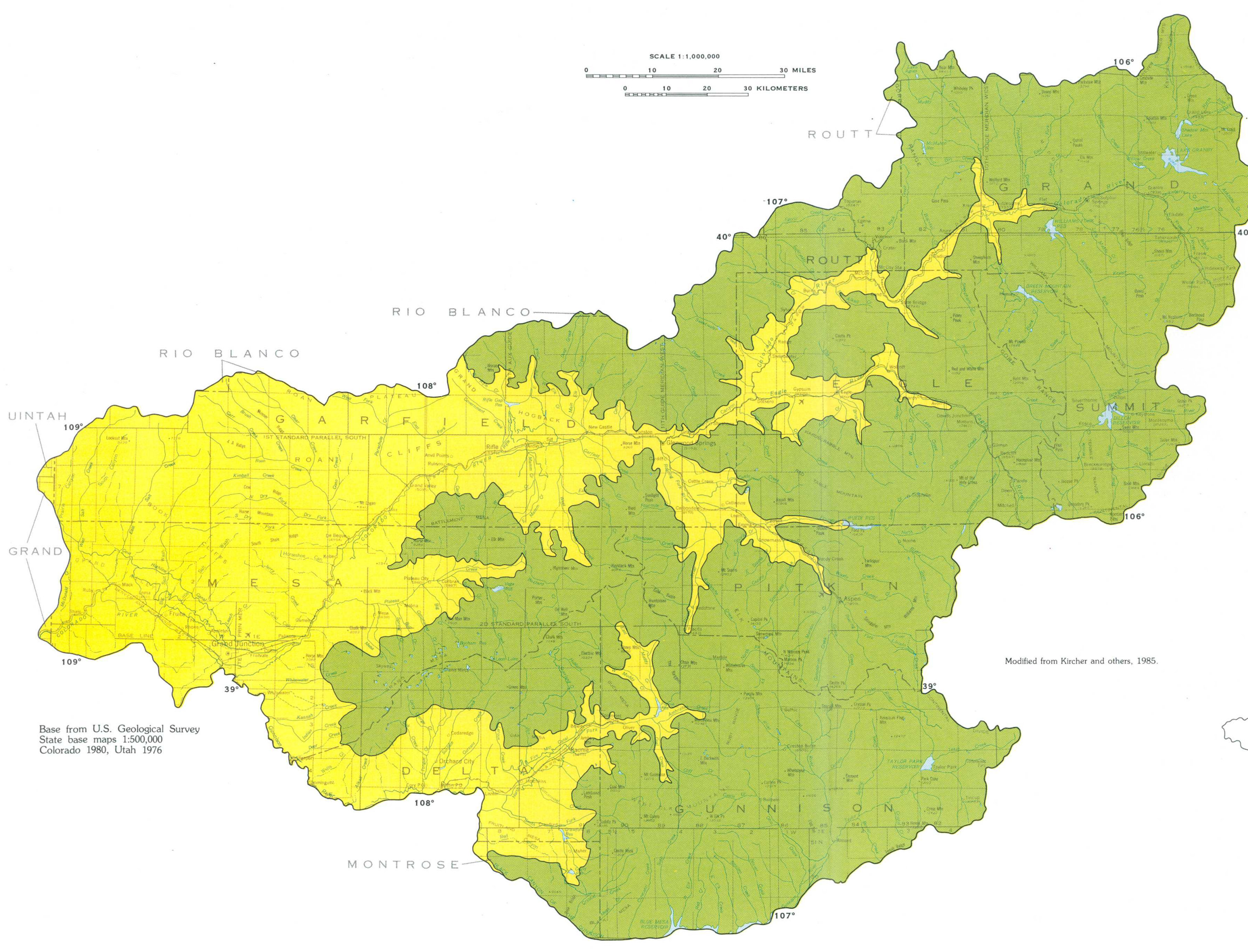

EXPLANATION

MOUNTAIN REGION

NORTHWEST REGION 


\subsection{SURFACE-WATER QUANTITY--Continued}

\section{Transmountain Diversions Averaged about 510,000 Acre-Feet}

Per Year from 1973 to 1982

Fourteen diversions move water from west to east of the Continental Divide primarily to meet irrigation and municipal water demand.

Fourteen transmountain streamflow diversions are listed in table 4.9-1, in addition to the average, maximum, and minimum annual diversion imate locations of the diversions and the relative magnitudes of the average annual diversion amount are shown in figure 4.9-1. The magnitude of the average annual streamflow of selected stream segments in basins from which the diversions are made also is shown. Not every diversion in the area is included; several diversions having average annual diversion amounts smaller than those listed in table 4.9-1 are in the area. Also, other diversions have existed in the past and have been discontinued or replaced by some of the more recent diversion structures. Diversion and streamflow data for the 1973-82 water years were used in the analysis in this report because the . E. Petsh, U.S. Geological Survey, written com mun., 1984).

Transmountain diversions generally are made near the mountain sources of the streams from
which the streamflow is diverted. The amount of streamflow diverted can be a significant part of streamflow nearthese sources, but the significance decreases farther downstream as the volume of flow increases. For example, the average amoun of streamflow diverted from the Colorado Rive through the Alva B. Adams tunnel (table 4.9-1) is about 4.5 times greater than the average streamflow in the Colorado River immediately downstream from the diversion. However, muc farther downstream in the vicinity of Kremmling Colorado, average streamflow in the river is about diversio through the tunnel (fig. 4.9-1).
For the diversions listed in table 4.9-1, the total average annual transmountain diversion of average annual streamflow at station 214 (fig. 4.2-1), Colorado River near Colorado-Utah State line. This station drains all of Area 58, in addition to some areas outside Area 58. An average of about 1,500 acre-feet of streamflow is diverted from this outside area by other transmountain diversions. ariations in the annual diversion rates (table 4.9-1) are primarily the result of variations in demand and availability of supply. Records of streamflow diversion by these and other diversions, as well as other data, such as exact location, are available in published reports described in section 4.2, Streamflow-Gaging Stations, and from com-

The transmountain diversions from the western to the eastern slope of the Continental Divide generally supply irrigation and municipal water Large areas in eastern Colorado, especially in and adjacent to the valleys of the South Platte in and adjacent to the valleys of the South Platte River, were developed as irrigated cropland during the late 1800 's. Because of this and water demands farther downstream on these rivers in Kansas and Nebraska, streamflow in eastern Colorado was over-appropriated by 1900 . Few suitable reservoir sites were available to store excess streamflow during the snowmelt period; consequently, streamflow at times was inadequate to meet the demands for irrigation water, especially later in the growing season during July, August, and
Diversion of streamflow from the Colorado River and its tributaries to streams on the eastern side of the Continental Divide was viewed as an in the Coloraro River ban warn was not appropriated to the extent that it today, so water was available. The first transmountain diversion constructed in the area was Ewing ditch, which began diverting water during 1880 (fig. 4.9-1; table 4.9-1). The diverted water, however, originally was used for placer mining but has been used for irrigation since about 1912 (U.S. Geological Survey, 1954, p. 90).

The first transmountain diversion constructed in the area solely to provide additional irrigation water for the eastern slope was the Grand River ditch (fig. 4.9-1; table 4.9-1). Water was diverted through the first segment of this ditch during 1892 (U.S. Geological Survey, 1954, p. 24). Construction continued until the length was 11 miles in 1897, and an addional 3 miles was added about 1930 (Arps and Kingery, 1966, p. 90). Construction of these early diversion difficulties and the economic cost of these diversions the number of diversions and the a diverwater diverted was not very large well in to the 1900 's. For example, the last 3 miles of the Grand River ditch was constructed with the aid of machines, at a reported cost of about $\$ 500$, compared to a cost of $\$ 375,000$ for the first 11 miles (Arps and Kingery, 1966, p. 90).
The need for additional water on the eastern slope and new, improved technology led to a large across the Continental Divide am The lar the Alva B. Adams tunnel (fig 4.9-1; table 49-1), began operation during 1947. This diversion is of the Colorado-Big Thompson Project, which began during 1935 and was designed to deliver up to 310,000 acre-feet of water annually from the Colorado River to the Big Thompson River, a tributary of the South Platte River. The project provides supplemental water to approximately 720,000 acres and more than 400,000 people (U.S. Bureau of Reclamation, no date). The Alva B. Adams tunnel accounts for about 46 percent of the average annual streamflow currently (1984) diverted out of the area.

About 25 percent of the streamflow that is diverted across the Continental Divide is for the municipal water supply of the Denver, Colorado, me tunnel (fid 4 . R-1; table 49-1). Finally, water percent of the streamflow diverted goe a Arkansas River to supplement water supplies in that basin. The major diversions into the Arkansas River basin are the Busk-Ivanho Charles $\mathrm{H}$. Boustead, Homestake, and Twin Lakes tunnels (fig. 4.9-1; table 4.9-1) 


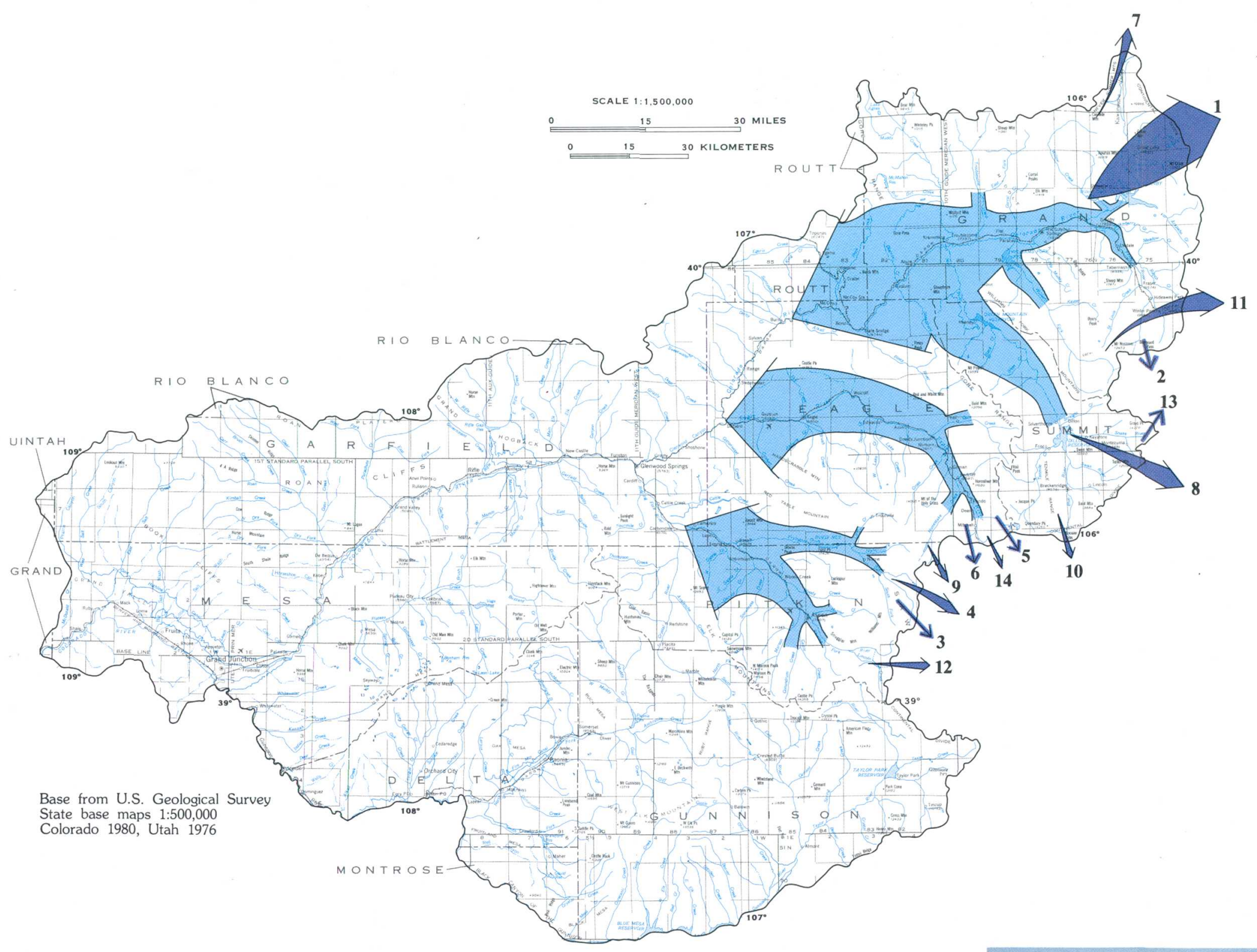

Table 4.9-1 Average, maximum, and minimum annual streamflow diversion for selected transmountain diversions for the 1973-1982 water years (Diversions in acre-feet per year)

\begin{tabular}{cllrrrr}
\hline $\begin{array}{c}\text { Map } \\
\text { number }\end{array}$ & $\begin{array}{l}\text { Station } \\
\text { number }\end{array}$ & \multicolumn{1}{c}{ Diversion name } & $\begin{array}{c}\text { Year } \\
\text { diversion } \\
\text { began }\end{array}$ & $\begin{array}{c}\text { Average } \\
\text { diversion }\end{array}$ & $\begin{array}{l}\text { Maximum } \\
\text { diversion }\end{array}$ & $\begin{array}{l}\text { Minimum } \\
\text { diversion }\end{array}$ \\
\hline 1 & 09013000 & Alva B. Adams tunne1 & 1947 & 237,160 & 294,400 & 158,900 \\
2 & 09021500 & Berthoud Pass ditch & 1910 & 536 & 809 & 322 \\
3 & 09077500 & Busk-Ivanhee tunne1 & 1925 & 5,450 & 7,470 & 3,110 \\
4 & 09077160 & Charles H. Boustead tunne1 & 1972 & 41,470 & 75,490 & 11,410 \\
5 & 09061500 & Columbine ditch & 1931 & 1,690 & 2,040 & 921 \\
6 & 09062000 & Ewing ditch & 1880 & 1,020 & 1,590 & 428 \\
7 & 09010000 & Grand River ditch & 1892 & 17,540 & 25,230 & 13,330 \\
8 & 09050590 & Harold D. Roberts tunne1 & 1963 & 67,723 & 133,800 & 2,250 \\
9 & 09063700 & Homestake tunne1 & 1967 & 24,310 & 59,870 & 0 \\
10 & 09042000 & Hoosiar Pas tunne1 & 1952 & 89,000 & 10,780 & 2,530 \\
11 & 0902500 & Moffat water tunne1 & 1936 & 59,120 & 87,840 & 33,170 \\
12 & 09073000 & Twin Lakes tunne1 & 1935 & 42,330 & 55,900 & 22,490 \\
13 & 09073000 & Vidler tunne1 & 1971 & 316 & 881 & 12 \\
14 & 09062500 & Wurtz ditch & 1932 & 2,910 & 4,310 & 765 \\
\hline
\end{tabular}

EXPLANATION

Transmountain streamflow diversio and number keyed to table 4.9-1

Streamflow for stream reacl

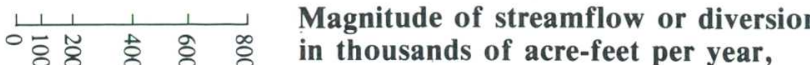
in thousands of acre-feet per year,

Figure 4.9-1 Average annual streamflow diversion for selected transmountain diversions and average annual streamflow for selected stream reaches for the 1973-1982 water years.

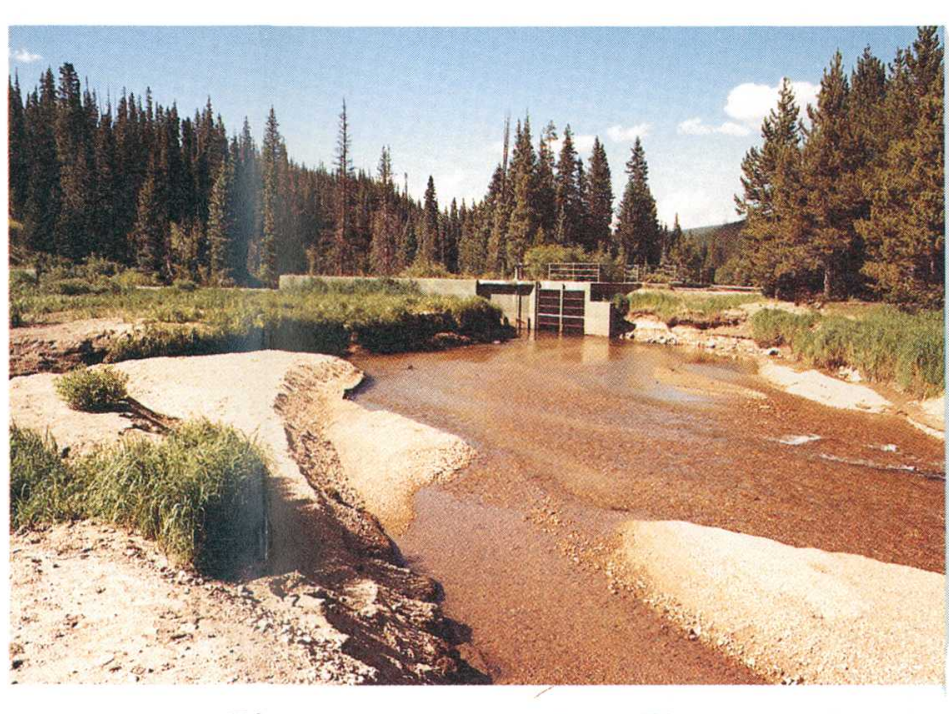

Diversion structure on Fraser River.

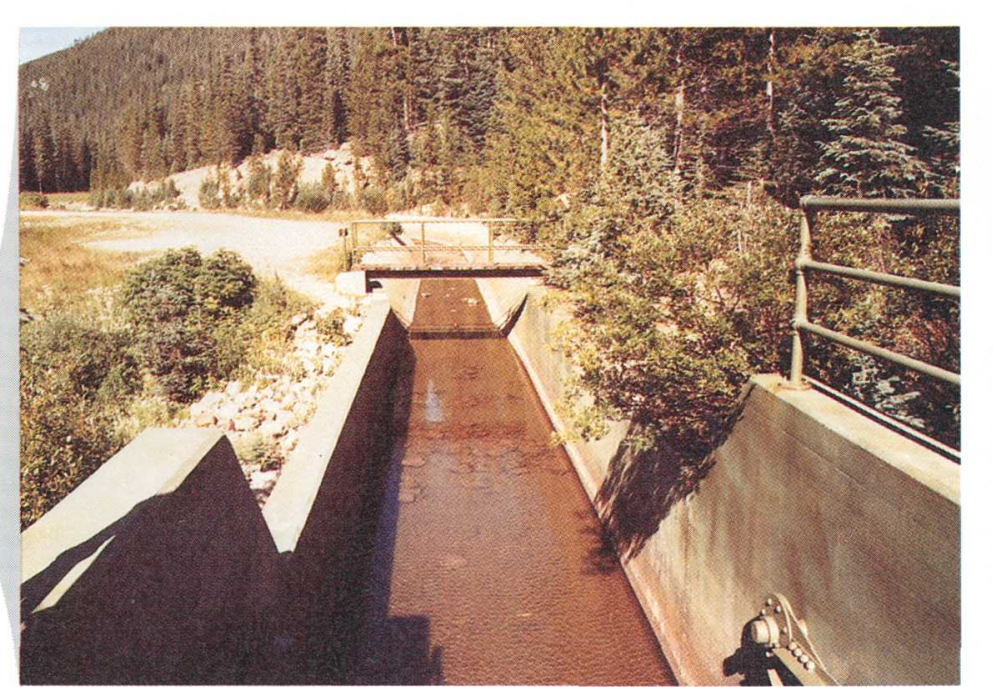

Canal carries diverted water to Moffat water tunnel. 


\title{
4.0 SURFACE-WATER QUANTITY--Continued \\ 4.10 Lakes and Reservoirs
}

\section{Surface-Water Storage Exceeds 2.3 Million Acre-Feet}

\author{
Storage of surface water in lakes and reservoirs in Area 58 exceeds \\ 2.3 million acre-feet; most of this storage is in a few large reservoirs.
}

Surface water, or streamflow, provides about 99 percent of the water supplies in the area (see section 3.3). However, because streamflow is quite variable, as described in section 4.5, streamflow during some periods is inadequate to provide reliable, year-round water supplies. Storage in reservoirs of high flows during snowmelt has increased the amount and reliability of year-round water supplies.

Selected lakes and reservoirs in the area (fig. 4.10-1) are listed in table 4.10-1. This table includes only the larger impoundments for which data were readily available. Dozens of small reservoirs are in the area, providing water for a variety of uses. Total storage capacity of the lakes and reservoirs listed is more than 2.3 million acre-feet, which is about 56 percent of the 1959-83 average annual streamflow at station 214, Colorado River near Colorado-Utah State line. The drainage basin of this station includes all of the study area plus about 4,700 square miles outside the area.

Most of the surface-water storage in the area is associated with three large water-resources development projects: (1) Currecanti Unit of the Colorado River Storage Project; (2) Colorado-Big Thompson Project; and (3) municipal water supply for the Denver, Colorado, metropolitan area. The first two projects are under the jurisdiction of the U.S. Bureau of Reclamation, and the third is administered by the Denver Board of Water Commissioners.

The reservoirs in or adjacent to the area that are part of the Currecanti Unit are Blue Mesa, Morrow Point, and Crystal (fig. 4.10-1; table 4.10-1), all on the Gunnison River (U.S. Bureau of Reclamation, 1981, p. 355-372). Blue Mesa is the largest body of water in the State of Colorado. Lake Granby, Grand Lake, and Shadow Mountain Lake, and Green Mountain and Willow Creek Reservoirs are components of the Colorado-Big Thompson Project (U.S. Bureau of Reclamation, 1981, p. 251-292). Finally, Dillon and Williams Fork Reservoirs are components of the metropolitan Denver water-supply system (Denver Water Department, 1983). These 10 lakes and reservoirs account for about 86 percent of the storage listed in table 4.10-1. Nine percent of the storage is in the following two reservoirs, which are components of other projects: (1) Ruedi Reservoir (U.S. Bureau of Reclamation, 1981, p. 487); and (2) Taylor Park Reservoir (U.S. Bureau of Reclamation, 1981, p. 1241).
In addition to the major impoundments listed in table 4.10-1 and the many smaller, unlisted manmade water bodies, the mountainous areas contain many small alpine lakes. Most of these lakes were formed by glacial action during the Pleistocene epoch. The total storage of these lakes is undetermined, but the U.S. Forest Service (1976) estimates that storage capacity in approximately 300 of these lakes on Grand Mesa is about 58,000 acre-feet. Some of these lakes, however, are manmade, or at least are enlargements of existing natural lakes. Lakes and reservoirs on Grand Mesa are an important water supply for several communities at lower elevations; two of the larger reservoirs are listed as numbers 2 and 3 in table $4.10-1$.

Many lakes and reservoirs, in addition to providing water supplies, are important recreation centers, especially for water-related recreation such as fishing and boating. The Dillon Reservoir, Lake Granby, and Grand Lake areas are important destinations for thousands of people annually, and these areas are considerably developed. The Blue Mesa-Morrow PointCrystal Reservoirs area also is important because of its recreational opportunities. This area is administered by the U.S. National Park Service as the Currecanti National Recreation Area. However, development is minimal; only campgrounds and related facilities are present because commercial and residential development generally is not permitted in the immediate vicinity of the reservoirs.

Hydrologic data for some lakes and reservoirs in the area are available in several reports by the U.S. Geological Survey: Alley and others (1979); Britton and Wentz (1980); Ficke and others (1977); Martin and Hanson (1966); and Spahr and Ruddy (1983). A study also is currently (1984) in progress to determine the effects of energy-production emmissions on Colorado lakes (Hawkinson and Lystrom, 1983, p. 44). Some publications relating to lakes and reservoirs also have been released by Colorado State University: Aukerman (1975); Aukerman and others (1977); Walsh (1980); and Walsh and others (1980). Additional data, such as daily contents or water-quality information, are available for some of the lakes and reservoirs listed here, as well as others not listed, from computer storage in WATSTORE, described in section 8.3. 

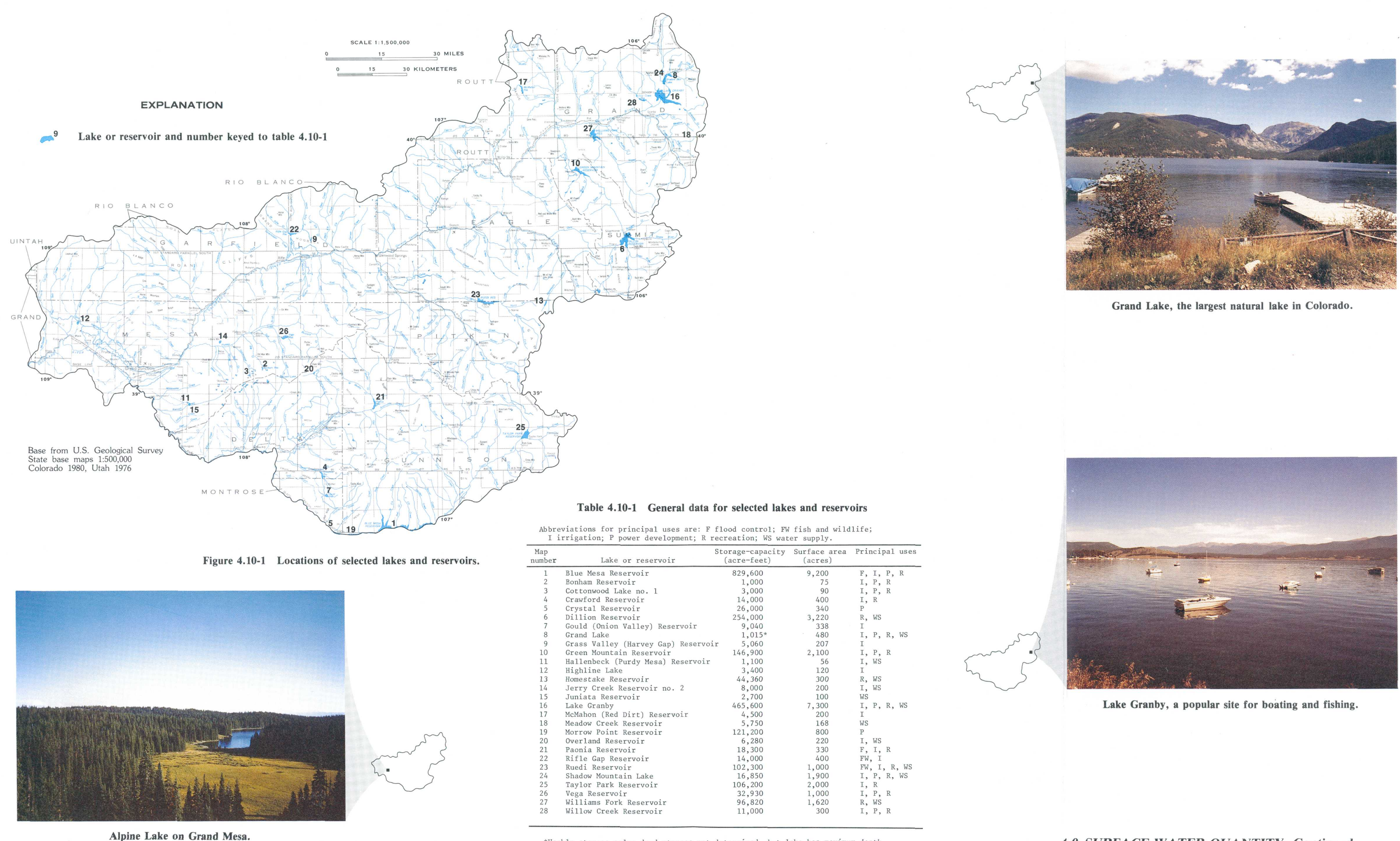

Grand Lake, the largest natural lake in Colorado.

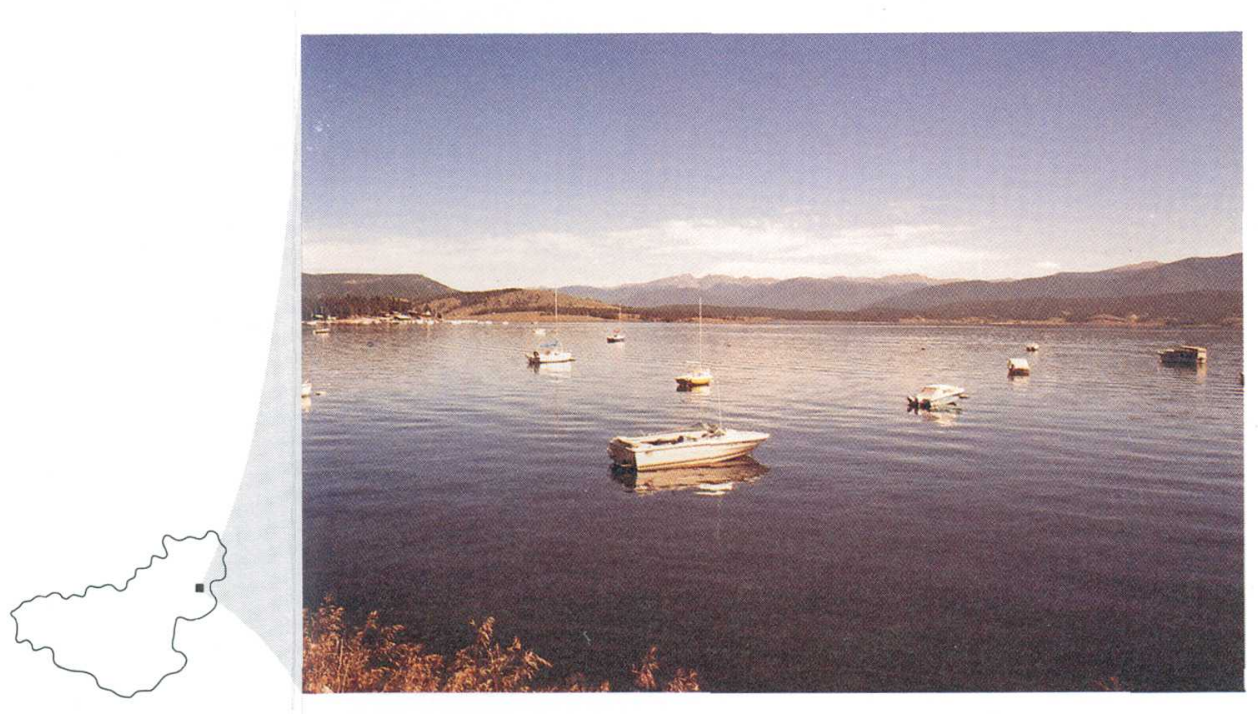

Lake Granby, a popular site for boating and fishing. 


\title{
5.0 SURFACE-WATER QUALITY \\ 5.1 Surface-Water-Quality Studies
}

\section{Water-Quality Studies Completed for Most of Area 58}

\author{
Water-quality data and analyses are available for most major \\ chemical constituents and many trace elements.
}

Studies by the U.S. Geological Survey discuss surface-water quality conditions for most of Area 58. Completed and ongoing studies and their locations are shown in figure 5.1-1.

Britton (1979) evaluated water-quality conditions in the Colorado River headwaters areas. Both chemical and biological data are presented in the report. Two studies (Alley and others, 1978a and $1978 \mathrm{~b}$ ) evaluated the quantity and quality of water resources in the Grand Hogback coal field and the Crested Butte coal field.

For the North Fork of the Gunnison River, which drains the Somerset coal field, the results of water-quality monitoring activities for major dissolved constituents and dissolved and suspended trace elements are presented in the report by Norris and Maura (1985). Further work in this basin will examine the relations between water-quality and geological and land-use conditions, including mining (J. M. Norris, U.S. Geological Survey, oral commun., 1984).

Two reports have been prepared that present data collected from 1975 to 1979 and 1980 to 1981 for the Roan and Parachute Creek drainage areas
(Patt and others, 1982; Galyean and others, 1985). A data-analysis report for these same periods also has been prepared (Adams and others, 1985).

The study area also is included in a number of regional water-quality reports. Wentz (1974) and Moran and Wentz (1974) discuss the effects of mine drainage on selected streams in Colorado, including several in Area 58. Gaydos (1980) presents a statistical summary of water-quality data for a number of sites in Area 58. Britton and Wentz (1980) provide water-quality data for a number of lakes and reservoirs located in the study area. Data are presented in their report for chemical, biological, and physical constituents. Richter and others (1984) summarize the basin characteristics including land-use characteristics of all basins draining Area 58.

Dissolved-solids concentrations in the Colorado River basin have been the focus of several studies. Iorns and others $(1964,1965)$ conducted a major study that includes Area 58. Kircher and others (1984) conducted a trend analysis of salt loads for four stations in the Colorado River basin, two of which are in Area 58. 

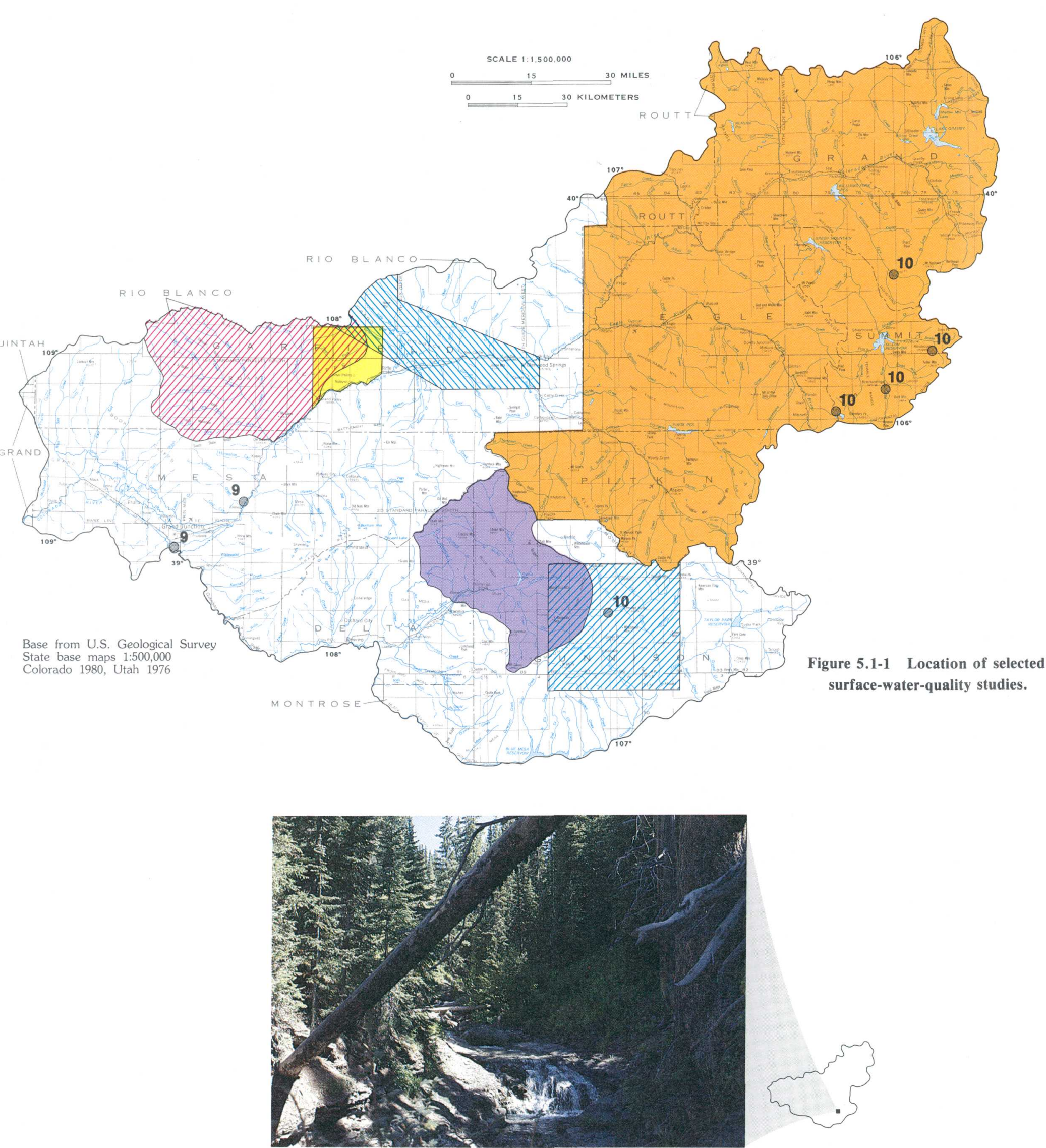

Ruby Anthracite Creek in the upper North Fork of the Gunnison River drainage area.
EXPLANATION

Britton, L.J., 1979, Reconaissance Evaluation of Surface-Water Quality in Eagle, Grand, Jackson, Pitkin, Routt, and Summit Counties.

Alley, W. M., Britton, L.J., and Boyd, E.J., 1978a, Reconnaissance Evaluation of Water Resources for Hydraulic Coal Mining, Crested Butte Coal Field, Gunnison County, Colorado.

Alley, W. M. Brittoln, L J, and Boyd, E. I., 1978b, Reconnaissance Evaluation of Water Resources for Hydraulic Coal Mining, Grand Hogback Coal Field, Garfield and Rio Blanco Counties, Colorado.

Norris, J.M., and Mauna, W.S., 1985, Water Quality Data for Streams in the Upper North Fork of the Gunnison River Basin, Colorado.

Patt, R.O., Adams, D.B., and Collins, D.L., 1982, Hydrologic Data from Naval Oil Shale Reserves, Parachute Creek Basin, Northwest Colorado, 1975-1979.

G Galyean, K.C., Adams, D.B., and Collins, D.L., 1985, Hydrologic Data from Naval Oil Shale Reserves, Parachute Creek Basin, Northwest Colorado, 1980-1981.

Adams, D. B., Goddard, K.E., Patt, R.D., and Galyean, K.C., 1985, Hydrologic Data from Roan Creek and Parachute Creek Basins, Northwest Colorado.

Butler, D.L., U.S. Geological Survey, Colorado District, Hydraulic and Water Quality Investigation 8 of Springs in Roan Creek and Parachute Creek Basins, Northwest Colorado, current study, Project Number CO-81-155.

\section{REGIONAL STUDIF}

Britton, L.J., and Wentz, D.A., 1980, Water-Quality Characteristics of Selected Lakes and Reservoirs in Colorado.

Gaydos, M.W., 1980, Summary of Water-Quality Data for Selected Streams in Colorado.

Iorns, W.V., Hembree, C.H., and Oakland, G.L., 1965, Water Resources of the Upper Colorado Basin-Technical Report.

lorns, W.V., Hembree, C.H., Phoenix, D.A., and Oakland, G.L., 1964, Water Resources of the Upper Colorado Basin-Basic Data.

Kircher, J.E., Dinicola, R.S., and Middleburg, R.F., 1984, Trend Analysis of Salt Load and Evaluation of the Frequency of Water-Quality Measurements for the Gunnison River in Colorado and the Delores River in Colorado and Utah.

10 Moran, R.E., and Wentz, D.A., 1974, Effects of Metal Mine Drainage on Water-Quality in Selected Areas of Colorado, 1972-1973.

Richter, B.D., Kircher, J.E., Remmers, M.A., and Forst, B.A., 1984, Summary of Basin an Streamflow Characteristics for Selected Basins in Western Colorado and Adjacent States.

Wentz, D.A., 1974, Effect of Mine Drainage on the Quality of Streams in Colorado, 1971-1972. 


\title{
5.0 SURFACE-WATER QUALITY--Continued \\ 5.2 Surface-Water-Quality Network
}

\section{Water-Quality Data for 77 Stations Presented in this Report}

\author{
Water-quality measurements are available for specific conductance, \\ dissolved solids, alkalinity, $\mathrm{pH}$, sulfates, iron, manganese, \\ trace elements, suspended sediment, and other constituents.
}

Coal-mining activities can affect surface-water quality in a number of ways. Water-quality constituents discussed in this report were selected based on their potential to change as a result of coal-mining activities (Wentz, 1974; Herbert, 1983). The constituents examined include specific conductance, dissolved solids, alkalinity, $\mathrm{pH}$, sulfates, iron, manganese, selected trace elements, and suspended sediment.

A total of 86 stations in Area 58 have some water-quality data available (section 9.1); however, only 12 stations presently (1984) are active. Of the total of 86 stations only 77 were used in this report. The 77 water-quality stations that were selected for use in this report have at least 5 water-quality samples available between October 1971 and June 1984. Seventeen of the stations used in this report have miscellaneous data available; these include some combination of streamflow, water-quality, or biological data. All stations are shown in figure $5.2-1$. The station numbers on the map refer to section 9.1, which lists all stations used in this report. The station name, longitude, latitude, period of record, and type of data available are listed in section 9.1 .

Many of the stations located on the North Fork of the Gunnison River were established to characterize the drainage from the Somerset coalmining area (station numbers 169, 172, 175, 217-230, 232, and 233). Stations 175, 220, and 223 are located downstream from the mining opera- tions. The water-quality conditions for stations located in East and West Salt Creek drainage areas (station numbers $205,206,210,211$ ) can be considered representative of water draining from the Book Cliffs coal field. Several stations in this same area have very small drainage areas and primarily were established to monitor irrigation return flows. Examples of these stations would be station numbers 198, 201, and 207 to 209.

For several of the sections in this chapter, the region was divided into three subareas. The three subareas, as shown in figure 5.2-1, were chosen because of their different physiographic, geologic, and climatic characteristics. Subarea 1 includes the mountainous headwaters of the Colorado River. Subarea 1 is underlain by metamorphic and sedimentary rocks and receives abundant precipitation, primarily snow. Subarea 2 includes the Gunnison River headwaters. This area also is mountainous and has significant precipitation levels-also as snow. Bedrock in this area, however, primarily is igneous and metamorphic rocks and has few sedimentary rocks. Subarea 3 includes the lower drainage areas of both the Colorado and the Gunnison Rivers and includes the Colorado Plateau. This subarea is considered semiarid because most of the subarea receives less than 20 inches of precipitation a year and is underlain almost entirely by sedimentary deposits, many of them of marine origin. 


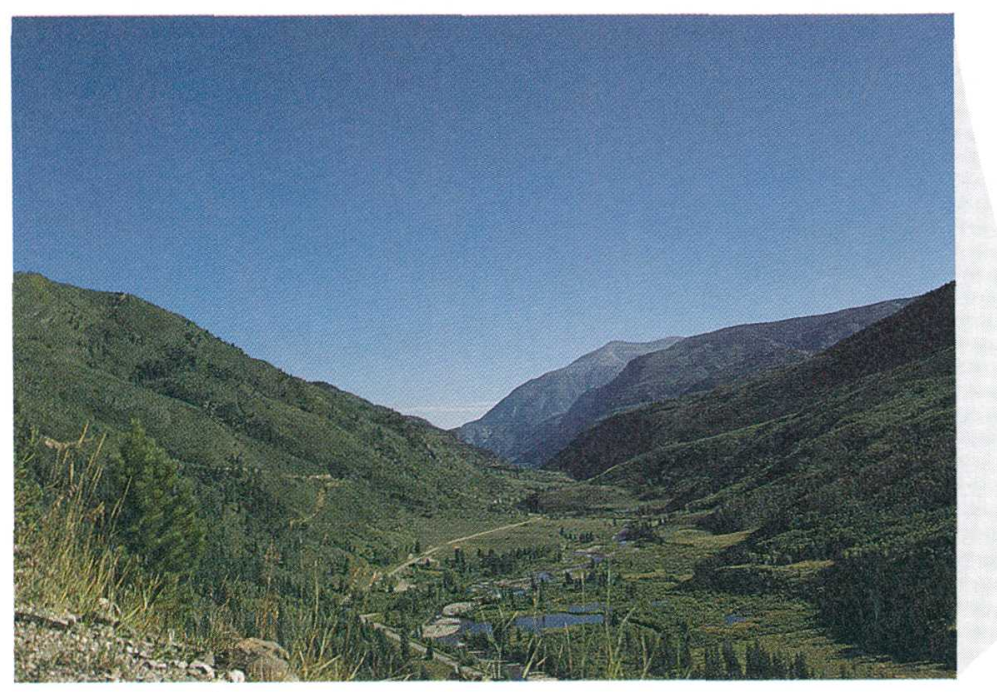

Crystal River Valley is typical of mountain stream drainage in subareas 1 and 2 .

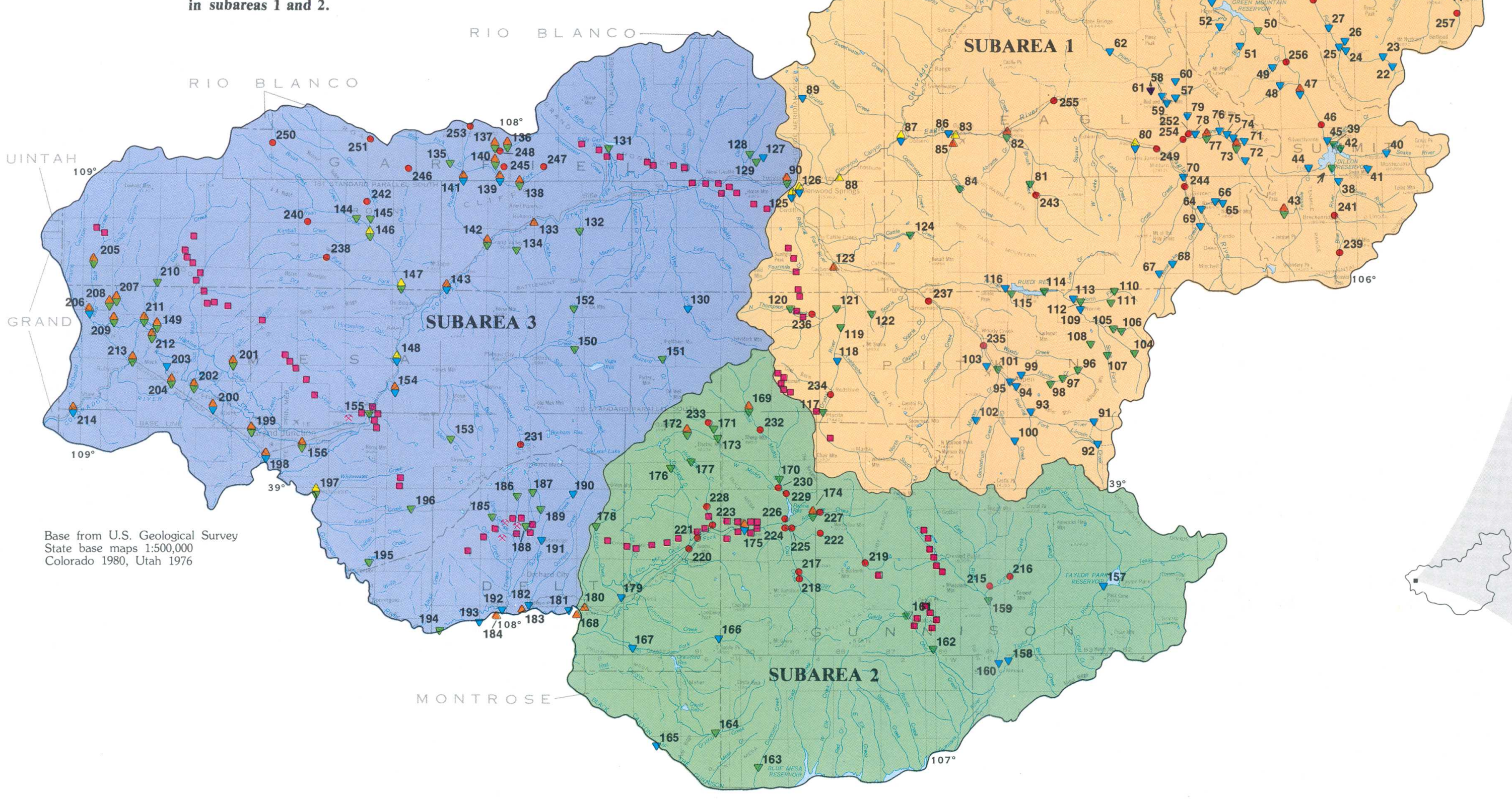

EXPLANATION

- Active streamflow-gaging station

$\nabla$ Inactive streamflow station

$\triangle$ Active water-quality station

Anactive water-quality station

- Miscellaneous water-quality and biological station

$\downarrow$ Active peak-flow station

- Subarea boundary

- Underground coal mine

$\times$ Surface coal mine

150 Station number

NoTE: Numbers shown on the map are referred to in section 9.
Status of stations as of October 1, 1984 .

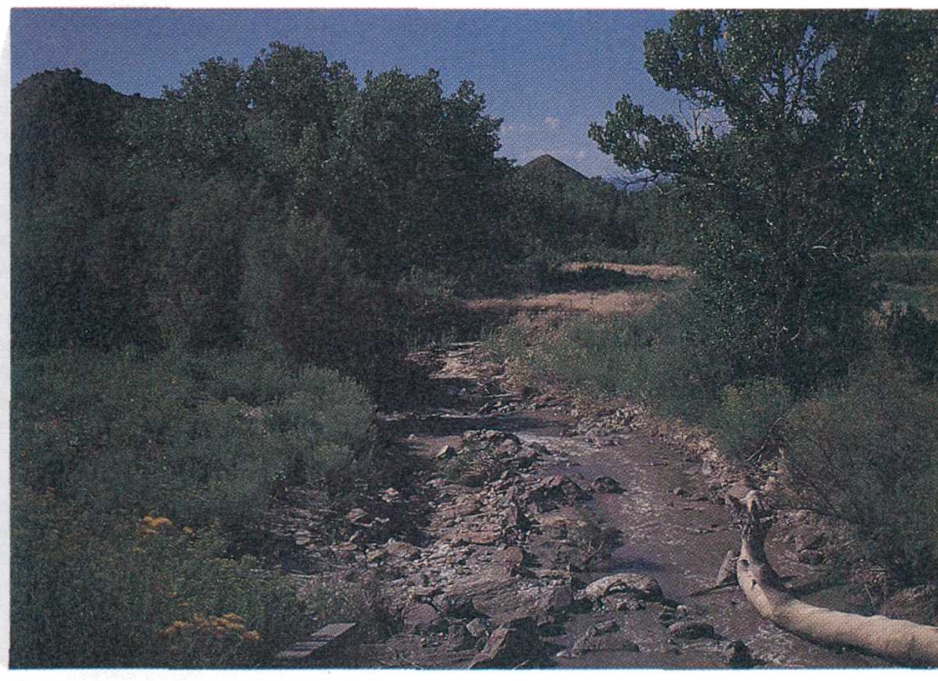

East Salt Creek is representative of perennial streams in subarea 3. These streams often have large concentrations of dissolved solids. 


\section{Dissolved-Solids Concentrations are Smallest in \\ Mountain Areas and Largest in Plateau Areas}

Geology, land use, and climate all affect the amount of dissolved solids found in surface waters.

The dissolved-solids concentration in a stream is a result of many factors including the dissolution of minerals from the soil and geologic formations in the drainage area. The average dissolvedshown in figure 5.3-1. Seans in the area is concentrations are the smallest in the headwater or mountain areas. Concentrations increase to a maximum in the plateau area along the Book Cliffs. In headwater areas in Area 58, the geologic formations generally are composed of resistant Precambrian rocks such as granites and othe metamorphic rocks. Measured dissolved-solids concentrations averaged as little as 38 milligrams per liter at station 7 near Granby. The areas underlain by sedimentary deposits in the central and western parts of Area 58 have average dissolved-solids concentrations that are much greater. The largest concentrations occur in streams draining the Mancos Shale. Station 211 on East Salt Creek has the largest concentration in the study area, with an average dissolved-solids concentration of 3,760 milligrams per liter.

The Colorado River increases an average of 647 illigrams per liter of dissolved solids between station 20 , which has an average concentration of 84 (14 near the Utah in the headwaters, and station 731 milligrams per liter. Most of the inerage in dissolved-solids concentration has occurred by the time the water has reached De Beque (station 143 ), which has an average concentration of 516 milligrams per liter. These increases result from the inflows from numerous thermal springs along Glenwood Canyon and the Eagle River, which has in itsive gypsum deposits high in calcium sulfate

Dissolved-solids concentrations also vary in-

Dissolved-solids concentrations also vary in versely with streamflow. The average monthly configure 5.3-2. Dissolved-solids concentration decrease as runoff from snowmelt increases durin May, June, and July. Concentrations are gretes during low flow periods when ground water is the principal streamflow component. Ground water re mains in contact with the geologic formations for a longer period of time and dissolves larger amounts of mineral constituents. Although runof from snowmelt or rainfall contributes some dis solved solids, concentrations are small, and runoff dilutes the ground-water contribution, decreasin dissolved-solids concentrations. The arid parts of the study area have less available runoff to dilute dissolved solids leached by the ground water and, therefore, have large, average dissolved-solid concentrations.

Stations 83, 141, and 154 (fig. 5.3-2) show the reatest variation in dissolved-solids concentration dil of these stations are located in areas where re relatively large. When run fe ground wate dilution effect would be much ore the with smaller, overall discolved solids concentra- tion, such as stations 20 and 174 . These two stations are located in mountain headwater areas with bedrock formations that contribute little to the dissolved-solids concentrations.

Large concentrations of dissolved solids are of concern when water is used for irrigation. At con centrations greater than 500 milligrams per liter, damage to sensitive crops such as fruit trees can begin to occur, although adverse effects on most crops are not apparent until concentrations are greater 1,000 milligrams per liter (U.S. Environmental Protection Agency, 1976, p. 208. Average concentrations for the streams upstream from Glenwood Springs in the Colorado Rive drainage and upstream from Paonia on the North Fork of the Gunnison River all are less than 500 milligrams per liter. Downstream from Glenwood Springs, all stations on the Colorado River main 1,000 milligra drain than 1,000 milligrams per liter. This lower

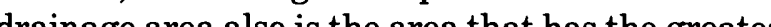
agricultural activity and is the most reliant on irrigation.

Specific conductance of water is a measure of its ability to conduct an electrical current. The ability to conduct current increases with the concentration of dissolved ions. Specific conductance is reported in micromhos per centimeter. Because specific conductance is easily measured onsite or in the laboratory, data are readily available. At stations where sufficient data are available, a correlation between dissolved solids and specific con ductance generally can be demonstrated. This rela tion enables extrapolation of results from one are to similar areas with the same type of water if either the specific-conductance value or dissolvedsolids concentration is known (Hem, 1970, p. 96).

The relation between dissolved solids and specific conductance was calculated for the three subareas described in section 5.1, and the results are shown in table 5.3-1. Subarea 1 represents the Colorado River headwaters; subarea 2 represents the Gunnison River headwaters; and subarea represents the lower drainage areas of the Gun nison and Colorado Rivers. The size of the drainage areas for the stations used in the analysis in al three subareas ranges from 10 to 325 square miles. An example of the application of the relation fo sissolved solids and specific

Dissolved solids $=0.601 \times$ specific conductance -1.5 If specific conductance equals 73 micromhos per
centimeter, the concentration will be 42 milligrams per liter. The factors presented in table 5.3-1 are only valid for the range of specific-conductance values shown in the table.

\section{Table 5.3-1-Relation of dissolved solids to specific conductance}

\begin{tabular}{|c|c|c|c|c|c|c|}
\hline Subarea & Slope & Intercept & $\begin{array}{c}\text { Standard error } \\
\text { of estimate } \\
\text { (milligrams per } \\
\text { liter) }\end{array}$ & $\mathbf{r}^{\mathbf{2}}$ & $\begin{array}{l}\text { Number of } \\
\text { data pairs }\end{array}$ & $\begin{array}{c}\text { Range of } \\
\text { specific con- } \\
\text { ductance } \\
\text { (micromhos } \\
\text { per centimeter) }\end{array}$ \\
\hline 1 & 0.601 & -1.5 & 9.6 & 0.959 & 67 & $54-342$ \\
\hline $\begin{array}{l}2 \\
3\end{array}$ & $\begin{array}{l}.533 \\
848\end{array}$ & $\begin{array}{r}+17 \\
-152\end{array}$ & $\begin{array}{l}206 \\
206\end{array}$ & $\begin{array}{l}.886 \\
980\end{array}$ & $\begin{array}{l}208 \\
762\end{array}$ & $\begin{array}{c}29-510 \\
370-13000\end{array}$ \\
\hline
\end{tabular}


EXPLANATION

AVERAGE DISSOLVED-SOLIDS CONCENTRATION, N MILLIGRAMS PER LITER

$\triangle \quad 0-250$

251-500

$\triangle \quad 501-1000$

$\triangle \quad 1001-2000$

$\triangle \quad 2001-3000$

- 3001-4000

$53 \quad$ Station number

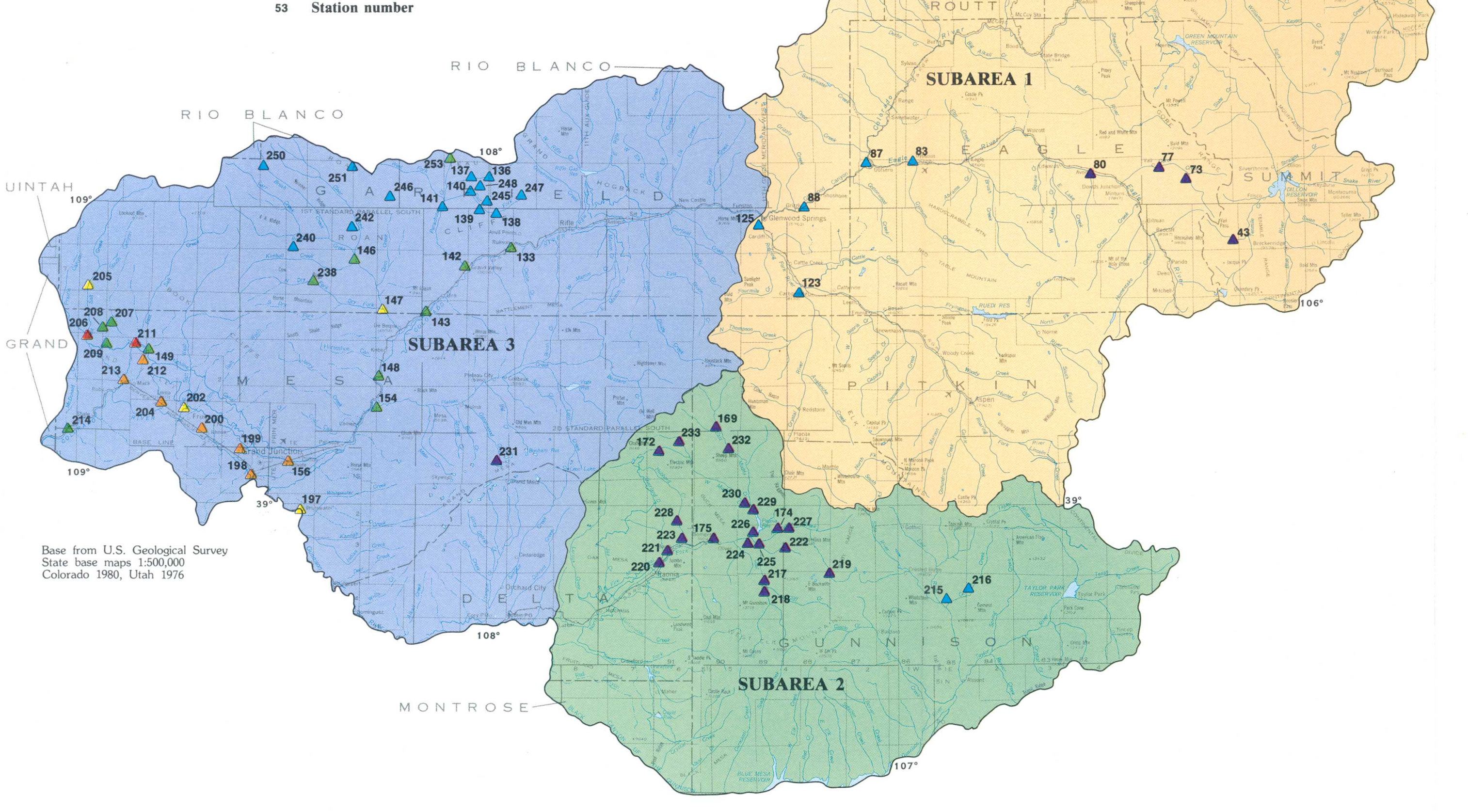

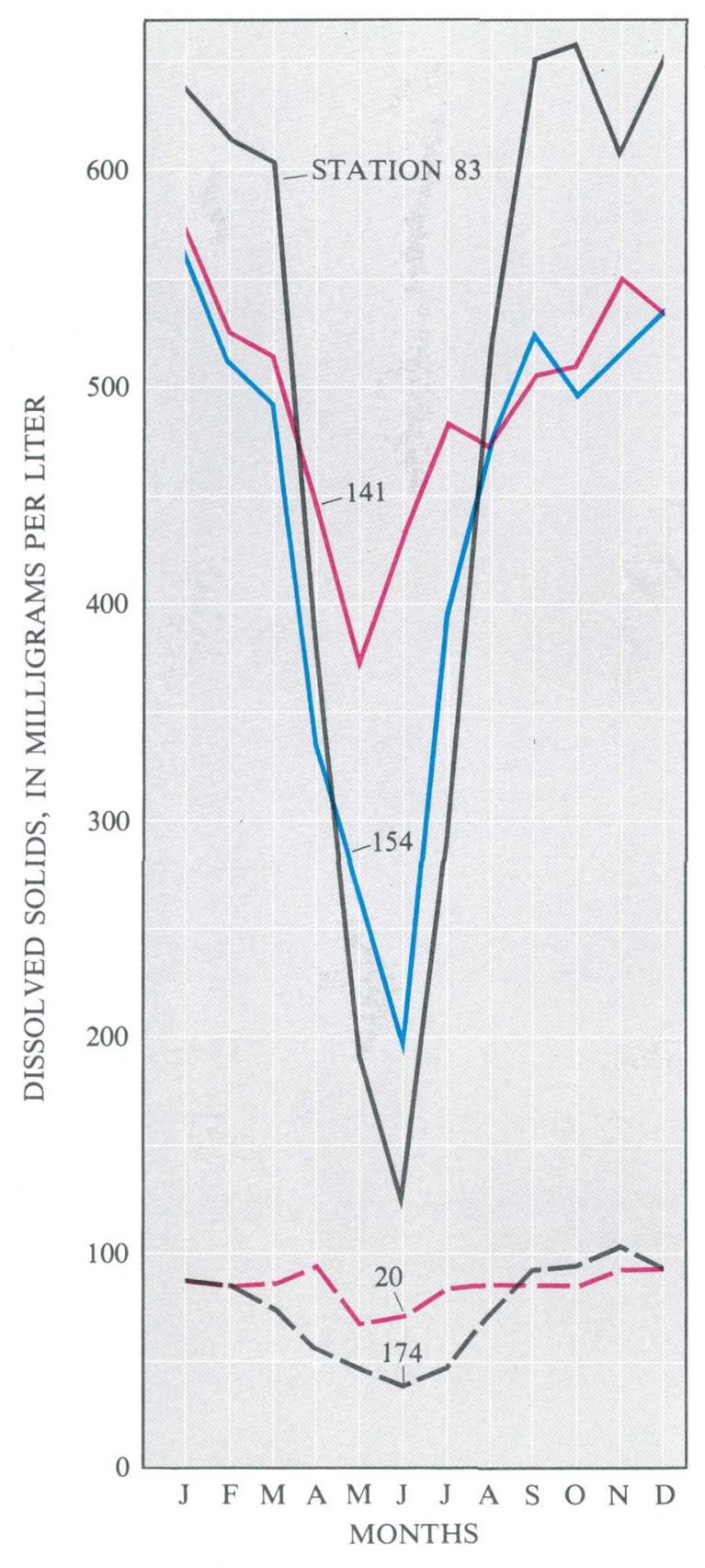

Figure 5.3-2 Average monthly dissolvedsolids concentrations at selected water-quality stations. 


\title{
5.0 SURFACE-WATER QUALITY--Continued 5.4 Alkalinity and $p H$
}

\section{Streams Generally Well Buffered Because of Substantial Alkalinity}

\author{
Largest concentrations of alkalinities occur in the Roan and Book Cliff areas; \\ smallest concentrations are in mountain headwater areas.
}

\begin{abstract}
Average alkalinity concentrations (in milligrams per liter as calcium carbonate) measured at water-quality stations in Area 58 are shown in figure 5.4-1. The average alkalinity concentrations for individual stations range from 24 milligrams per liter to 423 milligrams per liter. Alkalinity concentrations generally are not of concern until they are less than 20 milligrams per liter. At that level, water can become corrosive (U.S. Environmental Protection Agency, 1976, p. 7). Concentrations up to 400 milligrams per liter are not considered a human health problem (U.S. Environmental Protection Agency, 1976). The largest average alkalinity concentrations (more than 300 milligrams per liter) generally occur in the streams draining the Roan and Book Cliffs areas. The smallest concentrations occur in the mountain headwater areas. The actual measured range of alkalinity concentrations was from 17 milligrams per liter to 480 milligrams per liter.
\end{abstract}

The presence of alkalinity is important because it moderates or buffers changes in $\mathrm{pH}$, decreasing the possible impact on aquatic organisms. Also, the bicarbonate and carbonate ion components of alkalinity can form complexes with toxic metals to reduce their toxicity (U.S. Environmental Protection Agency, 1976).

A frequency distribution of all $\mathrm{pH}$ measurements in Area 58 is shown in figure 5.4-2. Two-thirds of the $\mathrm{pH}$ values are in the range of 7.6 to 8.5 . Hem $(1970$, p. 93$)$ reports that natural stream-water $\mathrm{pH}$ values generally range between 6.5 and 8.5 . Only 8 percent of the values in the area are outside this range. Values for $\mathrm{pH}$ between 6.5 and 9.0 also are considered adequate to protect freshwater fish and bottom-dwelling invertebrate organisms (U.S. Environmental Protection Agency, 1976, p. 178).

Median $\mathrm{pH}$ and average alkalinity concentrations for water at selected stations are shown in figure 5.4-3. Very little variation in $\mathrm{pH}$ exists between stations in the area (fig. 5.4-3). Alkalinity, however, is highly variable. Headwater areas in the mountains typically have small alkalinity concentrations, such as those measured at stations 7, 73, 225, and 232. In the instance of the North Fork of the Gunnison River (stations 172, 217, 224), these small concentrations may be of concern. The North Fork of the Gunnison River drains the Somerset coal field where several active coal mines are located. In general the smaller the alkalinity concentration in a stream, the less ability it has to buffer the impacts of acid mine drainage.

Much larger alkalinity concentrations occur in the areas underlain by sedimentary rock. These rocks generally contain large amounts of the carbonate minerals that produce alkalinity. Stations 141, 146, 211, and 238 typify these conditions. These stations also show a much greater range of concentrations because of the effect of the semiarid climate. In semiarid areas, carbonate, as well as other minerals, tend to concentrate on or near the soil surface. When runoff events occur, these minerals are flushed into the streams in large concentrations. 
EXPLANATION

AVERAGE ALKALINITY CONCENTRATION IN
MILLIGRAMS PER LITER AS CALCIUM CARBONATE

$\triangle \quad 0-50$

$\triangle \quad 51-100$

$\triangle \quad 101-200$

$\triangle \quad$ 201-400

$\triangle \quad$ Greater than 400

54 Station number

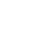

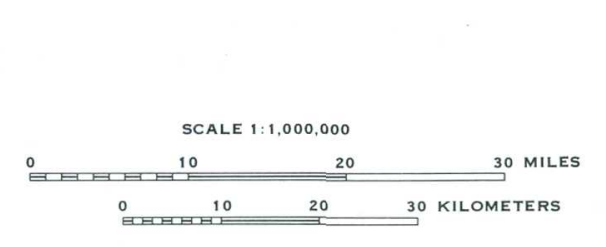

.

$S_{0}^{106^{\circ}}$
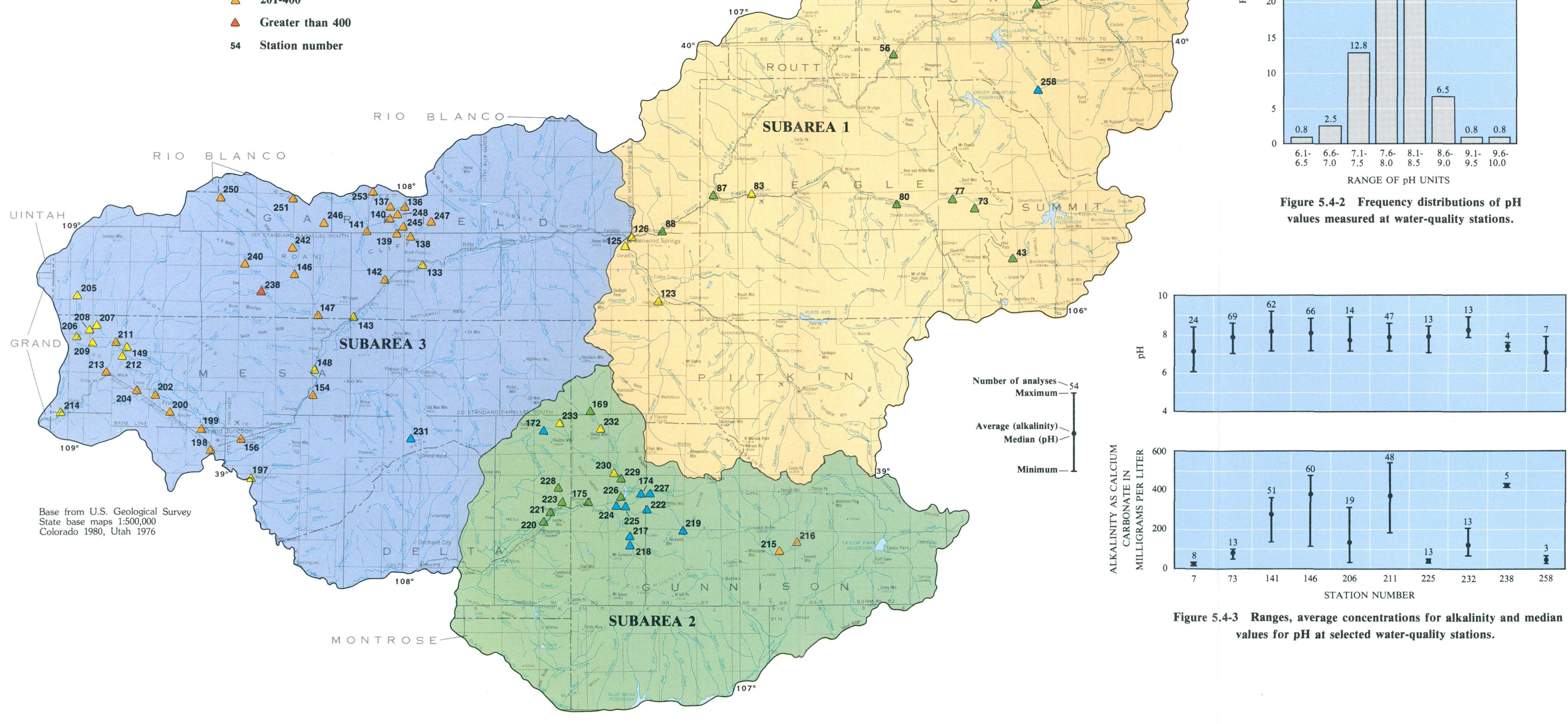

at water-quality stations. 


\title{
5.0 SURFACE-WATER QUALITY--Continued 5.5 Sulfate
}

\section{Sulfate Concentrations Largest in Semiarid Areas}

\author{
Sulfate concentrations in Area 58 streams are quite variable.
}

Sulfate in stream waters originates primarily from one of two sources: metallic sulfides or evaporite sediments. Metallic sulfides, such as pyrite, commonly are associated with coal deposits. As the coal is mined, the sulfides are exposed to weathering processes that result in oxidation to sulfate. Sulfate also is derived from the natural weathering of sedimentary rocks containing evaporites such as gypsum. The rate at which sulfate is removed from the rocks is dependent in part on the amount of runoff. In semiarid and arid areas where the amount of runoff is much less than precipitation, sulfate can accumulate more rapidly in the soil than it can be removed (Hem, 1970, p. 164).

In coal-mining areas, sulfate concentrations are of concern because of their association with acid mine drainage. The oxidation of pyrite can produce acidic conditions if the receiving stream lacks sufficient alkalinity to neutralize the acid and results in greater sulfate concentrations, which can indicate mine drainage (Detroy and others, 1983).

In Area 58, average sulfate concentrations in streams draining mined areas can vary greatly (fig. 5.5-1). Measurements from stations on streams draining coal areas in the North Fork of the Gunnison River all have small sulfate concentrations with average values of less than 25 milligrams per liter. Large, natural sulfate concentrations occur in the more arid parts of the study area along Roan and Book Cliffs. These areas are underlain by sedimentary rocks of marine origin that contribute to the large sulfate concentrations. Measurements at several stations in this area reflect irrigation-return flows that tend to have large sulfate concentrations because of evaporation losses that concentrate dissolved constituents. Because of this significant variation in sulfate concentration in the area, it is not always useful for indicating coal-mining drainage.
A frequency distribution of all sulfate concentrations (fig. 5.5-2) shows that concentrations ranged from 1 to 8,200 milligrams per liter. Seventy-nine percent of these concentrations are less than 250 milligrams per liter, which is the recommended maximum concentration for drinking water (U.S. Environmental Protection Agency, 1982b). Only 7.3 percent of the concentrations are greater than 1,000 milligrams per liter, indicating extreme concentrations are relatively uncommon. The largest concentrations are found consistently in the more arid areas underlain by sedimentary rocks.

The percent that individual chemical constituents contribute to the dissolved-solids composition for three subareas is shown in figure 5.5-3. These subareas, (1) Colorado River headwaters, (2) Gunnison River headwaters, and (3) lower Colorado and Gunnison River are the same divisions described in section 5.1. In subarea 1 , sulfate had an average concentration of 104 milligrams per liter, making it a major component. The average dissolved-solids concentration was 328 milligrams per liter for this subarea. Subarea 2 had an average sulfate concentration of only 12 milligrams per liter and an average dissolved-solids concentration of 170 milligrams per liter. In subarea 3 , sulfate is the major ionic component, and the average concentration is 646 milligrams per liter. Average dissolved solids for subarea 3 is 1,385 milligrams per liter. The major differences between subarea 1 and subarea 3 are the climate and the amount of drainage area underlain by sedimentary rock. Subarea 2 has a climate similar to subarea 1 but is underlain predominantly by igneous rocks that have minimal sulfate concentrations. 
EXPLANATION

AVERAGE SULFATE CONCENTRATION, IN MILLIGRAMS PER LITER

$\triangle \quad 0-100$

101-500

$\triangle \quad 501-1000$

$\triangle \quad 1001-2000$

$\triangle \quad$ 2001-3000

55 Station number

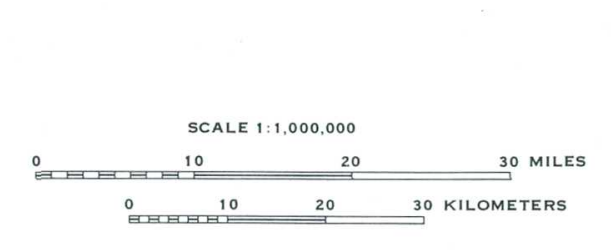

$\sum_{1}$

$\Omega_{3}$ ROUTT
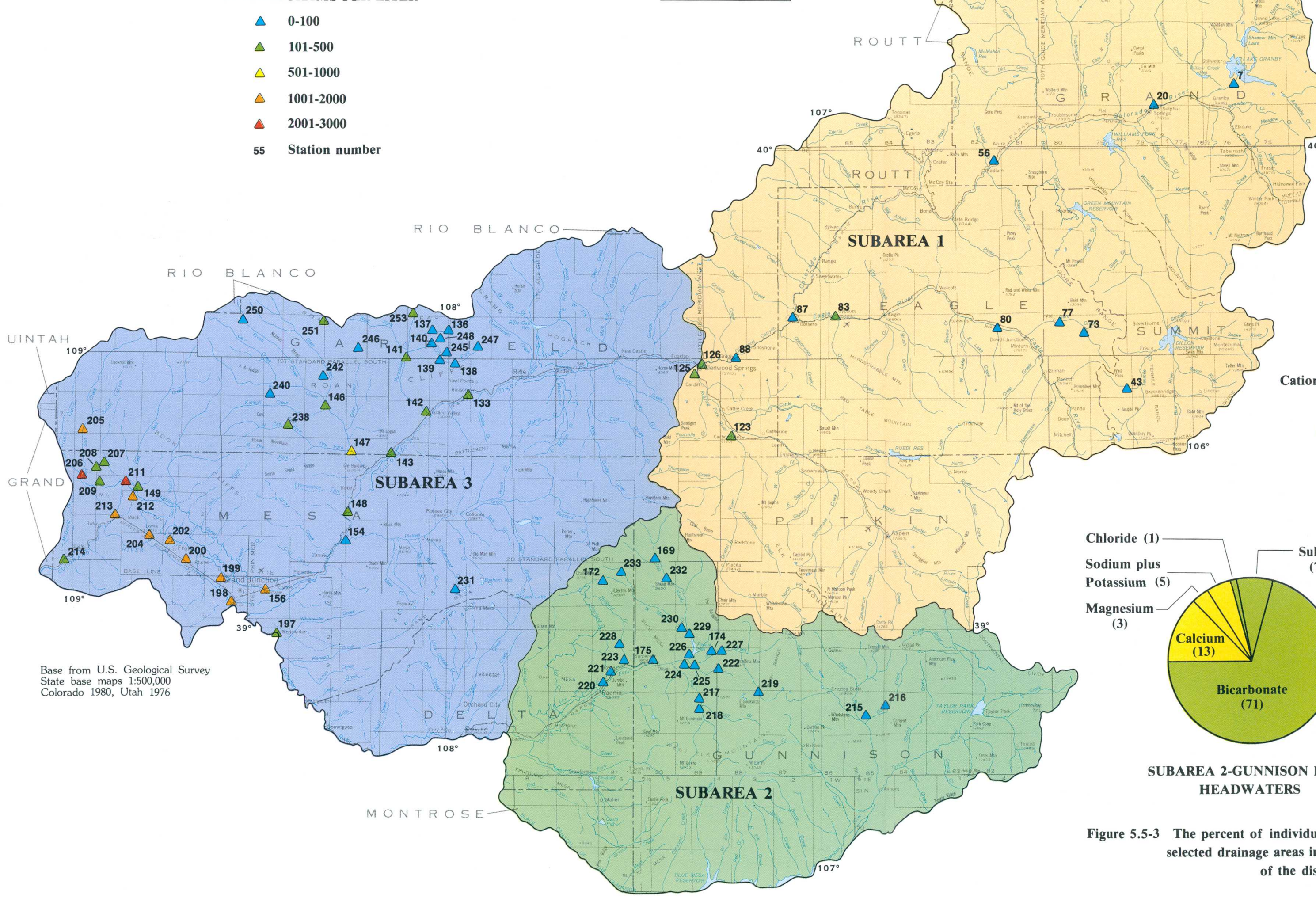

Figure 5.5-1 Average sulfate concentrations at water-quality stations.

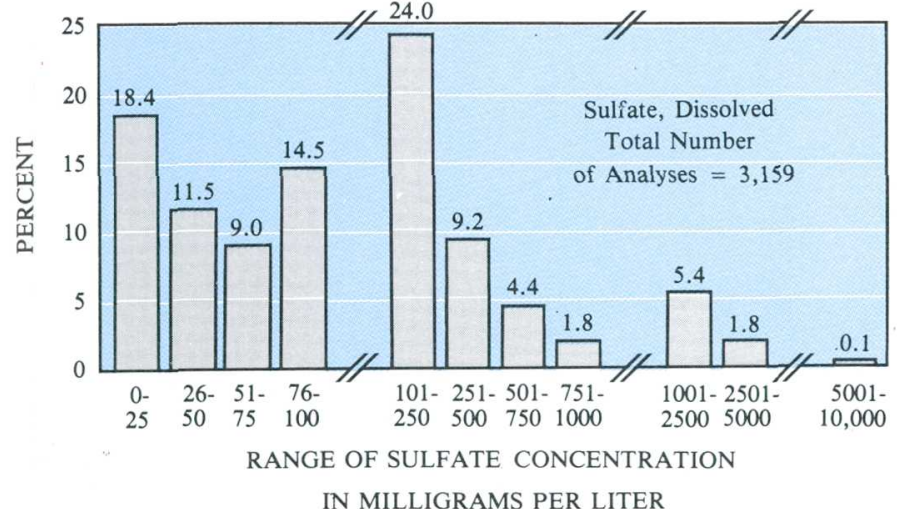

Figure 5.5-2 Frequency distributions of sulfate concentrations.

Sodium plus

(7) Chloride

$\underset{\text { (3) }}{\text { Magnesiu }}$

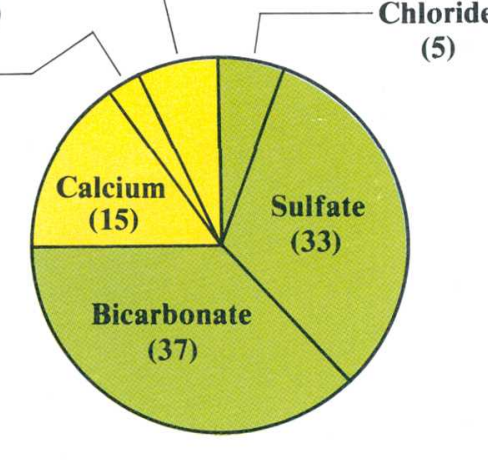

SUBAREA 1-COLORADO RIVER

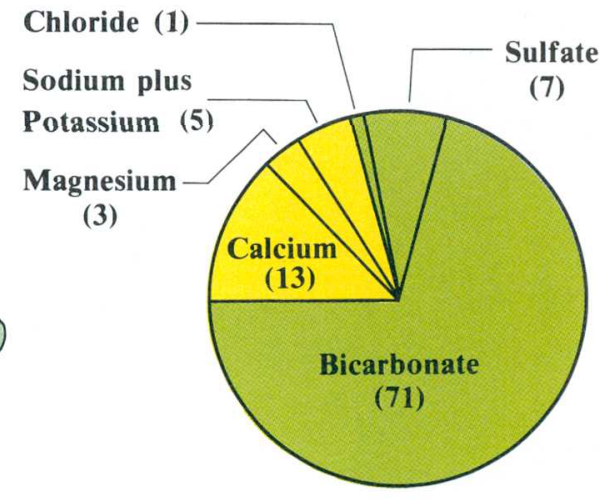

SUBAREA 2-GUNNISON RIVER HEADWATERS

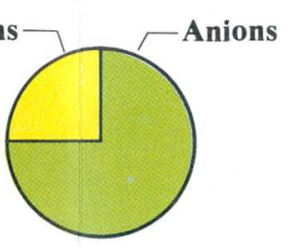

HEAD

SUBAREA 3-LOWER COLORADO AND GUNNISON RIVERS

The percent of individual constituent's contribution to the dissolved-solids composition for selected drainage areas in Area 58. Values are expressed as percent by weight of the dissolved-solids in milligrams per liter. 


\title{
5.0 SURFACE-WATER QUALITY--Continued 5.6 Iron
}

\section{Dissolved-Iron Concentrations Largest in Coal Areas}

\author{
Dissolved-iron concentrations rarely exceeded \\ recommended drinking-water standards.
}

Iron is among the most abundant elements in the Earth's crust, ranking fourth by weight. Iron commonly occurs in sedimentary and igneous rocks and is an important component of many soils. Iron is an essential element in both plant and animal metabolic processes. Under natural conditions, dissolved iron occurs primarily in the ferrous $\left(\mathrm{Fe}^{+2}\right)$ and the ferric $\left(\mathrm{Fe}^{+3}\right)$ forms. The ferrous form is common in ground water where minimal dissolved oxygen conditions exist. When these waters reach the surface and become oxygenated, iron oxidizes to the ferric form, which is much less soluble. Iron in the ferric or ferrous form is soluble under acidic $\mathrm{pH}$ conditions such as those found in industrial or mining discharges. The ferrous form also can complex with organic or humic compounds. Because of its low solubility, iron most often is found as a particulate either in suspended form or as a precipitate.

Dissolved iron, even at small concentrations, can limit water uses. The U.S. Environmental Protection Agency $(1976,1982 \mathrm{~b})$ recommends that iron concentrations not exceed 300 micrograms per liter for public water supplies. Concentrations in excess of this level can cause staining, impart a taste to the water, and require treatment for some industrial uses. At concentrations larger than 1,000 micrograms per liter (1.0 milligram per liter), iron can adversely affect aquatic life (U.S. Environmental Protection Agency, 1976, p. 79).

Average concentrations of dissolved iron are shown in figure 5.6-1. The averages for the sta- tions sampled range from 4.4 micrograms per liter to 214 micrograms per liter. The smallest concentrations are found in the Roan Cliffs area. Largest average concentrations are found in streams draining the Book Cliffs and the Somerset coal fields. The frequency distribution of values for dissolvediron concentrations is shown in figure 5.6-2. About 3 percent of the concentrations were larger than 250 micrograms per liter, indicating dissolved-iron concentrations are not a problem in Area 58 surface water.

Also shown in figure 5.6-2 is the frequency distribution of values for total recoverable iron concentrations. Because iron is found predominately in particulate form, these concentrations are much larger than those for dissolved iron. Concentrations for total recoverable iron range from 20 micrograms per liter to 71,000 micrograms per liter. The average concentration for Area 58 is 3,329 micrograms per liter. Large concentrations of total recoverable iron generally are not of concern because the majority of the iron is in particulate form and is unavailable to plants and animals.

These frequency distributions are somewhat biased because some stations have more data available than others. In the instance of total recoverable iron, the majority of analyses were made in the North Fork of the Gunnison River drainage area. 
AVERAGE DISSOLVED-IRON CONCENTRATION, IN MICROGRAMS PER LITER

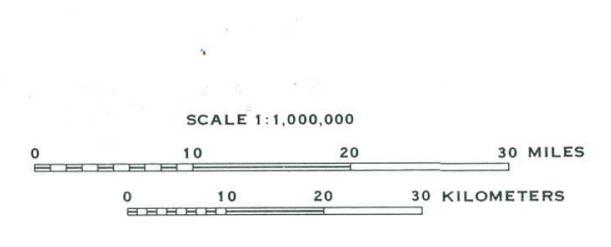

$\triangle \quad 0-50$

$\triangle \quad 51-100$

$\triangle \quad 101-200$

$\triangle \quad 201-300$

140 Site number

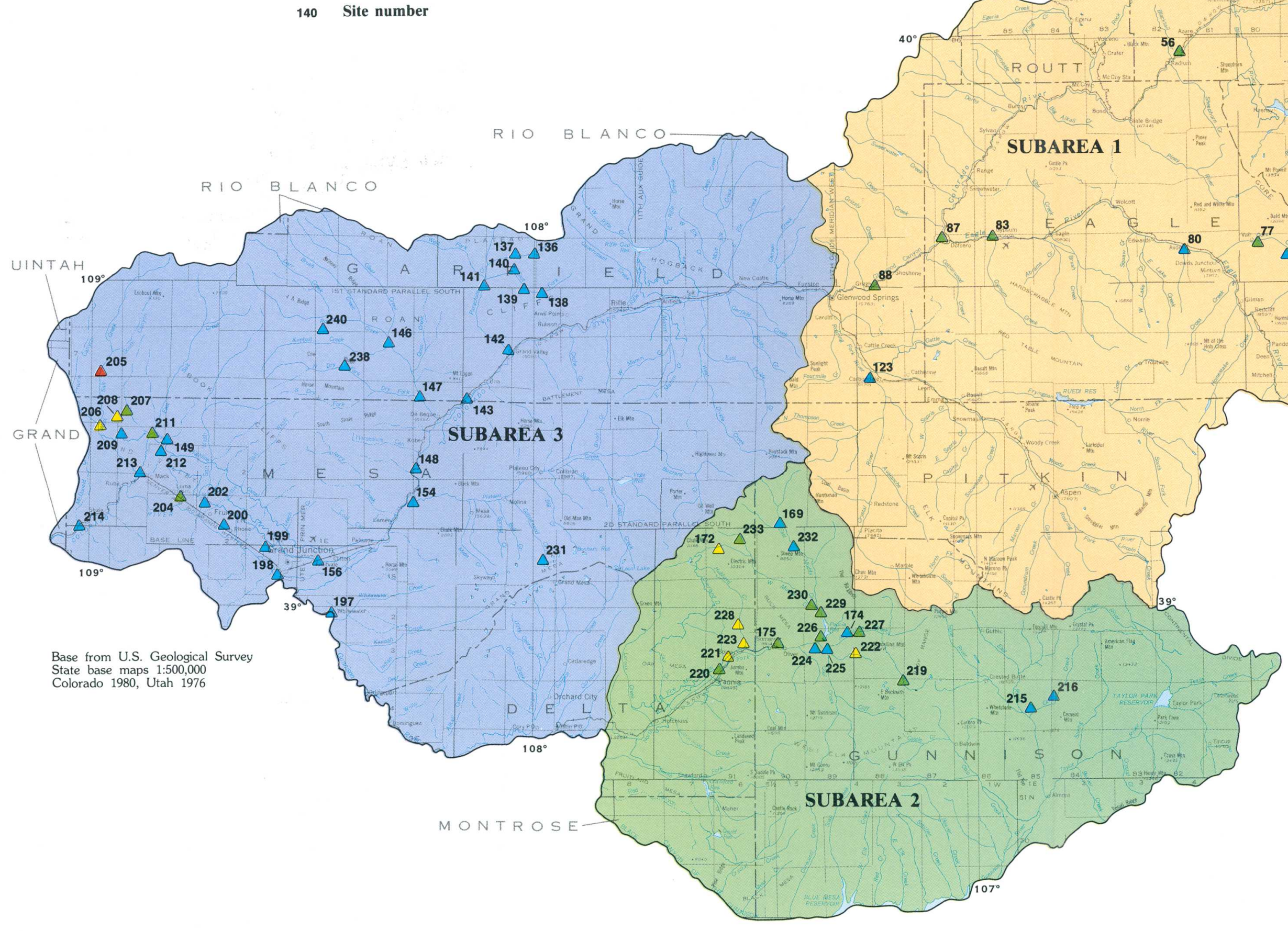

Figure 5.6-1 Average dissolved-iron concentrations at water-quality stations.

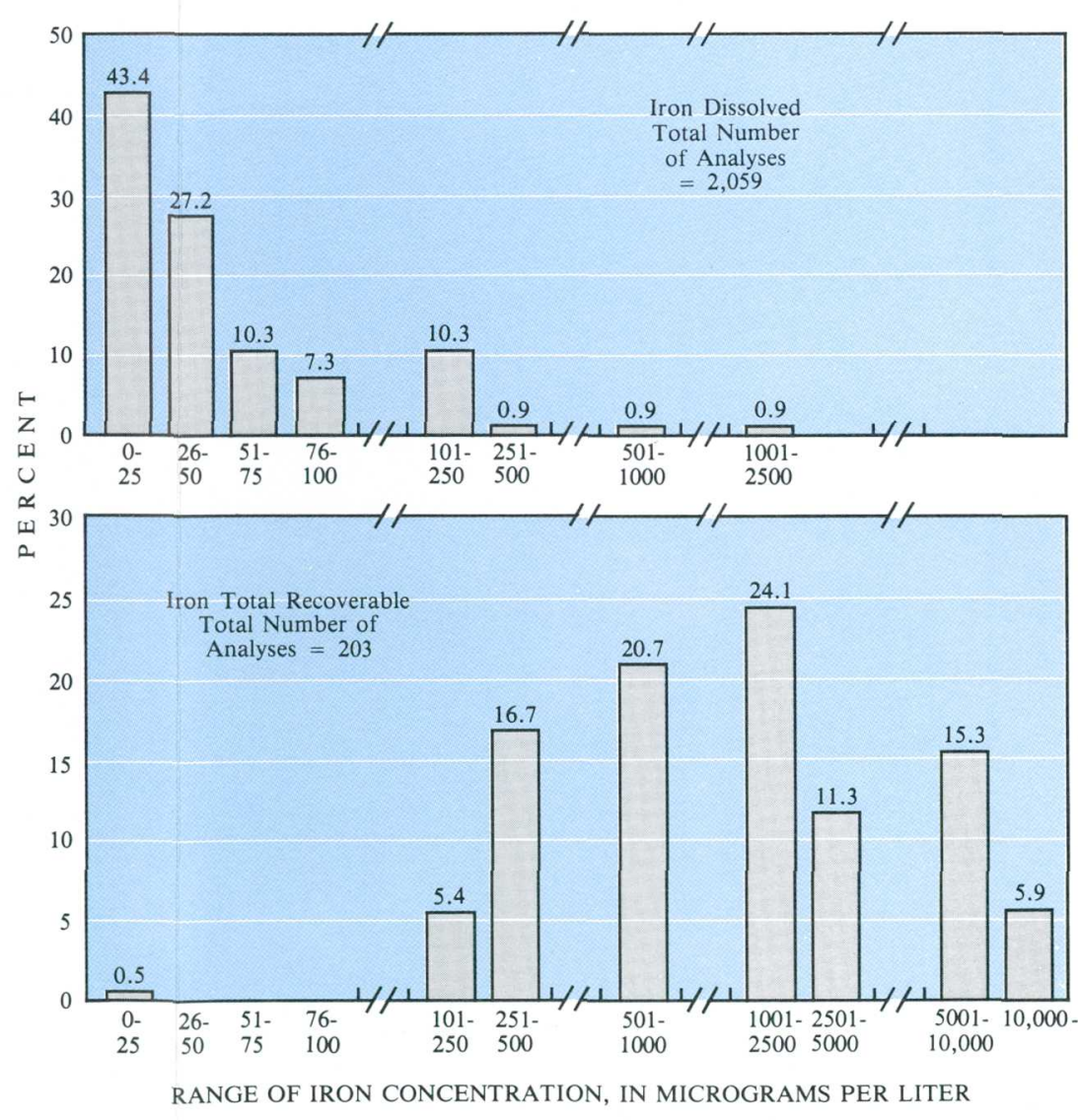

Figure 5.6-2 Frequency distributions of dissolved and total recoverable iron concentrations. 


\title{
5.0 SURFACE-WATER QUALITY--Continued 5.7 Manganese
}

\section{Manganese Exceeds Recommended Standards in Book Cliffs Area}

\author{
Concentrations of dissolved manganese vary greatly, \\ ranging from 1 to 1,400 micrograms per liter.
}

Manganese, although less abundant in the Earth's crust than iron, is still one of the most common elements. It is widely distributed in rocks and soils and is an essential micronutrient for both plants and animals. Manganese does not occur as a metal but is found in a variety of salts and minerals, often in association with iron compounds. Like iron, manganese compounds are minimally soluble in unpolluted natural waters. However, in water where there is little dissolved oxygen, as occurs in ground water, or where the $\mathrm{pH}$ is acidic, as is associated with some mine drainage, large dissolved-manganese concentrations can occur. In discharges with large concentrations of both iron and manganese, iron precipitates first and then manganese (Hem, 1970).

At concentrations larger than 50 micrograms per liter, dissolved manganese can inhibit some beneficial water uses. The U.S. Environmental Protection Agency $(1976,1982 \mathrm{~b})$ recommends concentrations of manganese in domestic water supplies of less than 50 micrograms per liter to prevent staining and objectionable tastes. Manganese is not considered to be a problem for freshwater aquatic life because it does not occur at concentrations approaching normal tolerance levels (U.S. Environmental Protection Agency, 1976, p. 96).

Average dissolved-manganese concentrations are shown in figure 5.7-1. The averages exceed the recommended drinking-water standard of 50 micrograms per liter, primarily in the Book Cliffs area. Several of the stations in this area $(156,198$, 199,200 , section 9.1) reflect agricultural return flows, which have larger manganese concentrations because evaporation tends to concentrate the dissolved constituents in irrigation-return flows. The average concentrations range from less than 1 microgram per liter to 415 micrograms per liter (station 205).

The frequency distribution of concentrations for dissolved manganese and total recoverable manganese in Area 58 are shown in figure 5.7-2. Concentrations for dissolved manganese range from 0 to 1,400 micrograms per liter. Approximately 20 percent of the dissolvedmanganese concentrations exceed the recommended 50 micrograms per liter standard. Total recoverable iron concentrations are much larger and indicate manganese's minimal solubility. The majority of the total recoverable manganese concentrations are for locations in the North Fork of the Gunnison River drainage area; no concentrations are available for the Book Cliffs drainage area. Averages for total recoverable manganese concentrations (not shown by figure) range from 10 micrograms per liter to 539 micrograms per liter. The frequency distributions are somewhat biased because some stations have more analyses than others. 
$\triangle \quad 0-50$

$\triangle \quad 51-100$

$\triangle \quad 101-250$

$\triangle \quad 251-500$

140 Site number
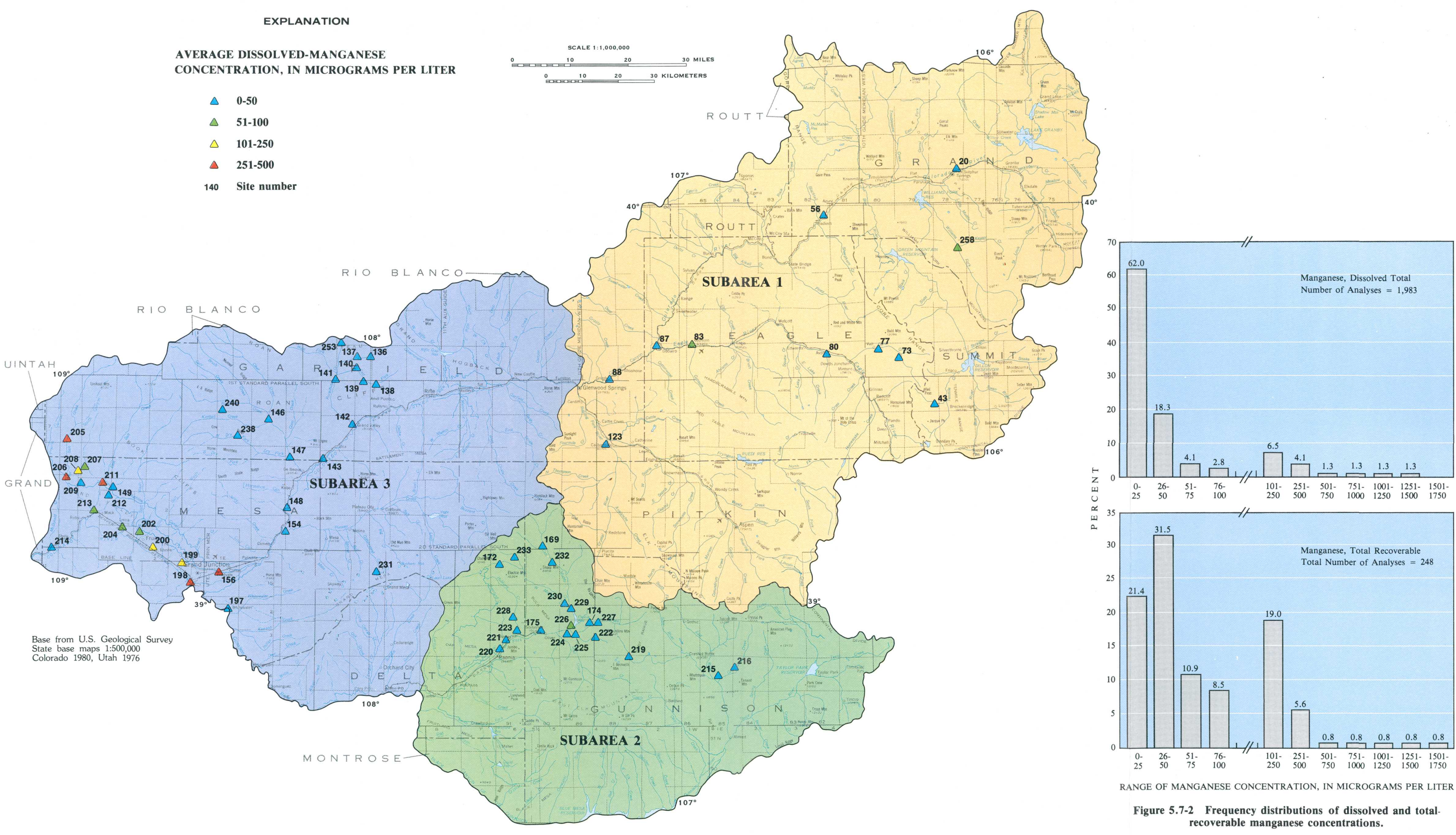

Figure 5.7-1 Average dissolved-manganese concentrations

at water-quality stations. 


\title{
5.0 SURFACE-WATER QUALITY--Continued 5.8 Trace Elements
}

\section{Lead Concentrations Commonly Exceed Drinking Water Standards}

\author{
Concentrations for 6 of 8 trace element constituents \\ analyzed exceeded recommended levels.
}

\begin{abstract}
Trace elements are those constituents that generally occur in concentrations of less than 1 milligram per liter. Many of these elements are essential in small amounts to plant or animal life but at larger concentrations become toxic. These elements occur naturally in geologic strata and soils, but activities such as mining can cause larger than normal concentrations to occur. The solubility of most of these elements is $\mathrm{pH}$ dependent. At neutral $\mathrm{pH}$ (7.0), trace elements such as cadmium, chromium, lead, or zinc occur in concentrations less than 0.05 micrograms per liter. As $\mathrm{pH}$ becomes more alkaline, their solubility decreases, but if conditions become more acidic ( $\mathrm{pH}$ of 6.0 or less) their solubility increases (Wallace and Berry, 1979).
\end{abstract}

In addition to being transported in the dissolved form, trace elements can become attached to sediment particles. Concentrations of a trace element obtained from the analysis of both water and suspended sediment are referred to as total recoverable concentrations. Concentrations obtained after the sediment has been filtered out indicate dissolved concentrations. Total recoverable concentrations for six trace elements at selected stations in Area 58 are shown in figure 5.8-1. Station locations are shown in figure 5.8-2 and section 9.1. Only trace elements that exceed a recommended water-use standard are shown here. Additional data are shown in section 9.2.

Arsenic, boron, cadmium, lead, mercury, molybdenum, and selenium all occur in coal deposits in amounts larger than their average composition in the Earth's crust. Chromium is a relatively common trace element in the area. Of these eight elements, arsenic, cadmium, chromium, lead, and mercury can be toxic to most biological systems when concentrations are in excess of certain levels. The other elements, boron, molybdenum, and selenium are of greatest concern because of their tendency to accumulate in plant tissues at concentrations that are harmful to livestock and wildlife when they consume the plants (U.S. National Committee for Geochemistry, 1980). Although all these trace elements usually are present in the environment in small amounts, many of them, such as lead and mer- cury, tend to accumulate over long periods in the systems of animals, eventually causing adverse effects on the animal.

The U.S. Environmental Protection Agency has issued standards for maximum concentrations of many of those trace elements in drinking water (U.S. Environmental Protection Agency, 1982a). The standards were issued under provisions of the Safe Drinking Water Act of 1974. The primary standards are established to protect public health (U.S. Environmental Protection Agency, 1982a).

Concentrations in excess of the recommended standards for different water uses were found for several trace elements. Twelve stations have some lead concentrations that exceed the U.S. Environmental Protection Agency standard of 50 micrograms per liter. These stations are distributed throughout the region. This relatively frequent exceedance of the standard is not surprising because of the region's geology. Lead is a common component of most metal deposits in Colorado (Wentz, 1974) and often can be found at levels in excess of the average in coal deposits in the area (Khalsa and Ladwig, 1981). The recommended concentration of molybdenum (10 micrograms per liter) is for water used to irrigate forage crops (National Academy of Sciences, 1972 , p. 344). The recommended concentration of molybdenum was exceeded at six stations. Other trace elements that had at least one analysis exceeding recommended standards are cadmium, chromium, mercury, and selenium.

Concentrations of total recoverable trace elements are of concern primarily only when the water is to be used for irrigation or for watering livestock. Water used for public drinking-water supplies generally is filtered before distribution removing trace elements suspended or attached to sediment. Therefore dissolved traceelement concentrations that exceed recommended standards are therefore of concern when the water is used for human consumption. 

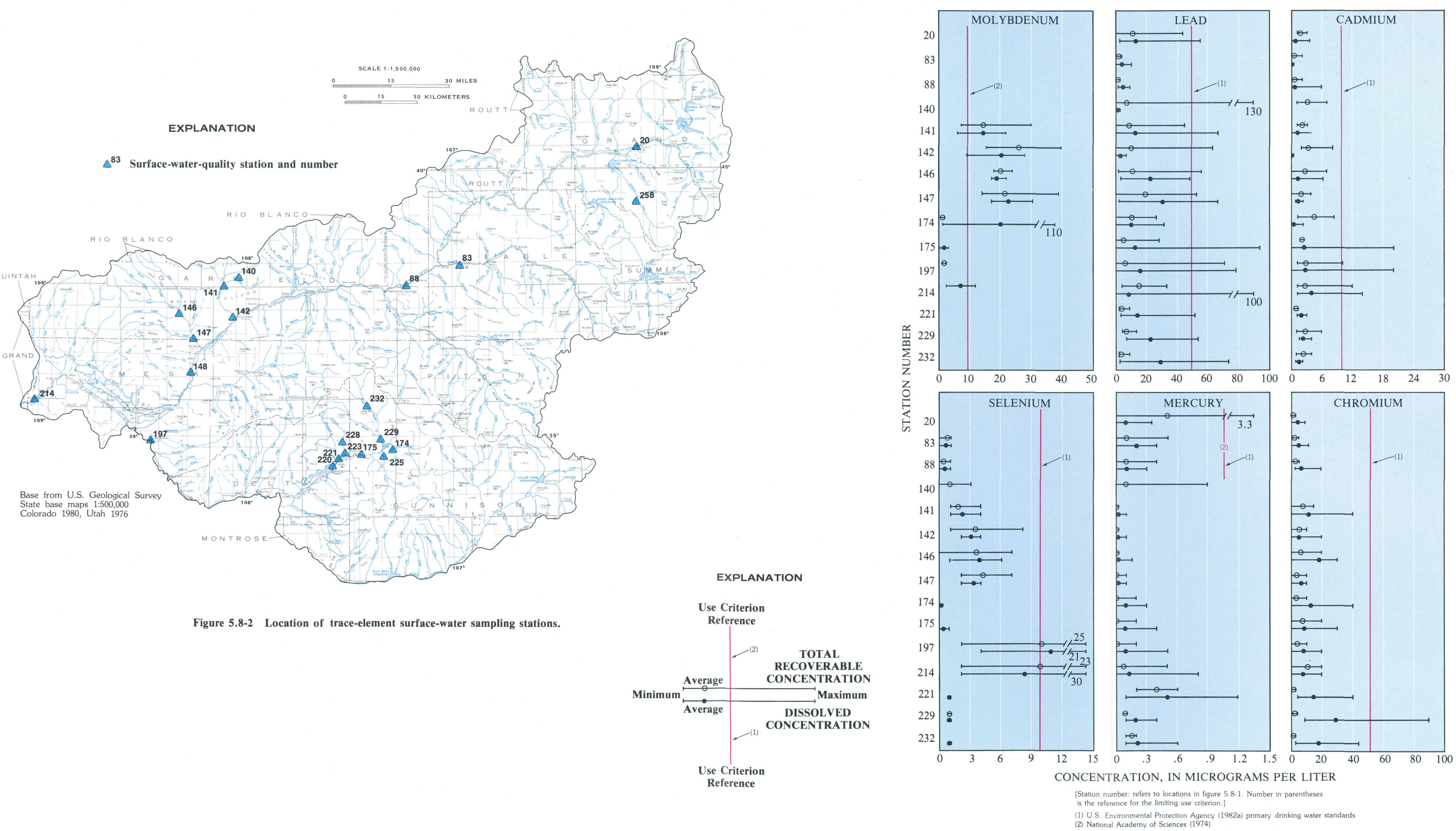

Figure 5.8-1 Summary of trace-element concentrations at selected stations. 


\title{
5.0 SURFACE-WATER QUALITY--Continued 5.9 Suspended Sediment
}

\section{Suspended-Sediment Yield Varies Substantially}

\author{
Annual suspended-sediment yield ranges from about 0.01 acre-foot per \\ square mile of drainage area per year in the high mountains to \\ greater than 1 acre-foot per square mile in the lowlands.
}

Suspended sediment in the streams within Area 58 is predominantly a result of channel erosion and soil erosion from overland flow. The sediment transported through and stored in a stream reach affects the water quality, channel cross-section, and flow hydraulics. Coal mining within the study area may affect the concentrations and discharges of sediment in the streams. The severity of sediment problems from surface coal mining and mining-related activities may be determined by defining the present conditions of streamflow and comparing it with post-mining impacts.

Suspended-sediment discharge is computed by combining suspended-sediment concentration with water discharge. Suspended-sediment concentrations have been measured, and the suspended-sediment discharges have been computed at some of the stations in the Colorado, Eagle, Gunnison, and Roaring Fork River basins. Some stations also have data on the size distribution of suspended sediment.

Measured suspended-sediment concentrations ranged from 1 to 79,100 milligrams per liter. Large concentrations usually occur during the spring runoff season when streamflow discharges are large and sediment is available. The large concentration is the result of a mudflow in one of the smaller basins. Small concentrations occurred during baseflow conditions on several of the smaller streams.

Suspended-sediment yields, in acre-feet per square mile of drainage area per year, were calculated using data collected at stations in the area. Subareas with similar suspended-sediment yields are shown in figure
5.9-1. The upper parts of the Colorado and Gunnison River basins had no suspended-sediment data so the yields are undetermined. These areas with undetermined yields are similar to the upper parts of the other basins and probably would have the same small suspendedsediment yield. The smallest yields occurred in the uppermost part of the basins where streamflows and sediment availability are the least. The upper parts of the basins have small mountain streams bordered by trees and other vegetation. The yields increased in a downstream direction in the lower part of the basins, possibly because man-related activities that disturb the soil are more concentrated at lower elevations and these activities make more sediment available. Along the main stem of the Colorado River, the yields increased considerably because of the cumulative effect of all the rivers in the study area eventually flowing into it.

Availability of particle-size distribution data for the suspended sediment is limited, but the data are remarkably consistent throughout the study area (fig. $5.9-2)$. The analyses show that almost 80 percent of the suspended sediment was silt and clay particles finer than 0.062 millimeters.

Relations between suspended-sediment discharge and water discharge for selected stations are shown in figure 5.9-3. These relations can be used to compute suspended-sediment discharge when water-discharge data are available. These relations should be used only within the range of water discharges for which suspended-sediment discharge has been calculated. 

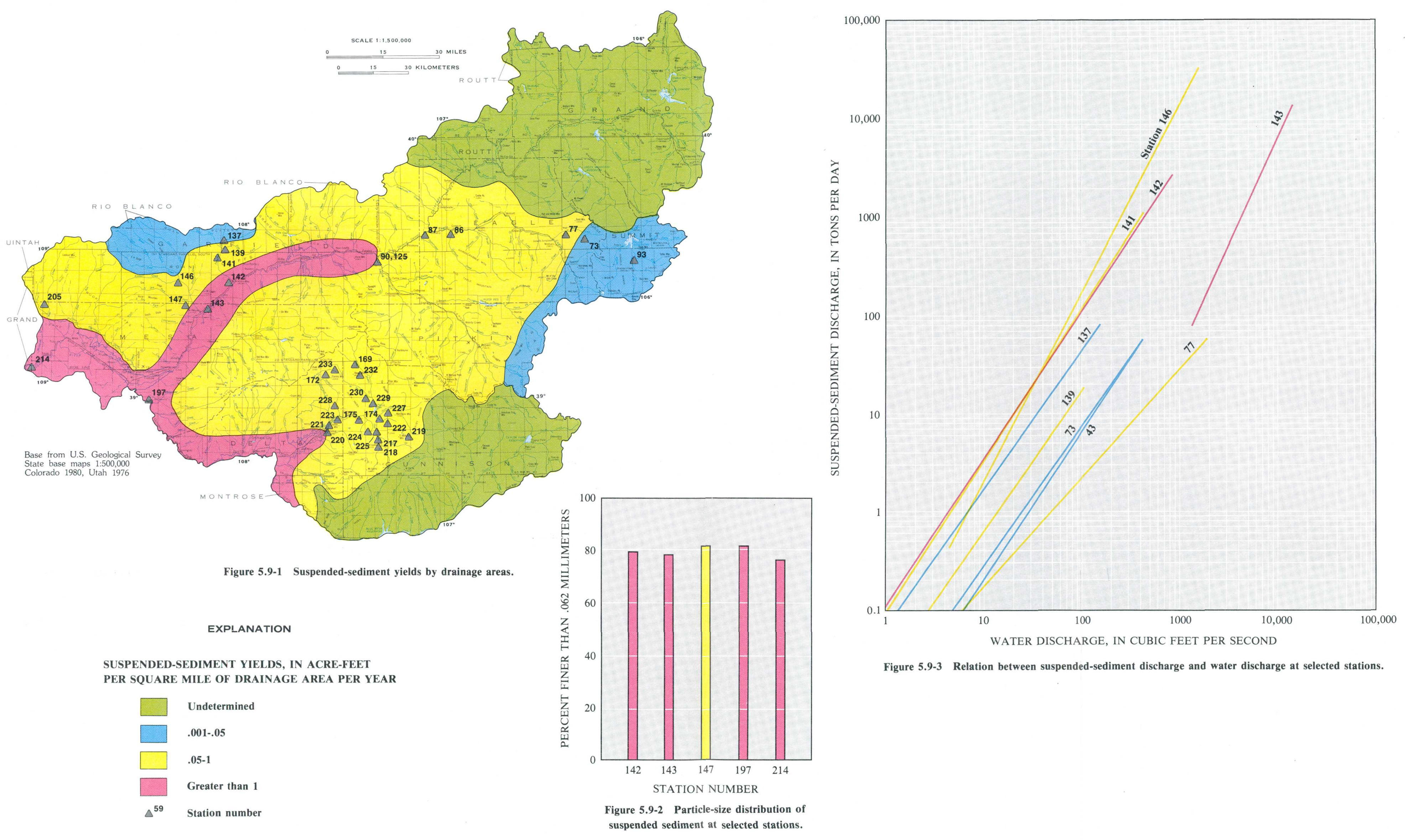

Figure 5.9-3 Relation between suspended-sediment discharge and water discharge at selected stations. 


\title{
6.0 GROUND WATER \\ 6.1 Well Data
}

\section{Most Productive Wells are in Valleys}

\author{
Most wells are completed in unconsolidated deposits \\ or fractured bedrock.
}

Little well information is available for Area 58 because most of the area is unsuitable for major groundwater development and because surface-water supplies usually are available. The low drylands in the western valleys are underlain by mineralized shales, and the mountainous eastern areas are relatively uninhabited. Geologic units described in section 2.2 of this report correspond to this section's description of ground water.

Depths to water vary in this area because of stratigraphy and topography. Depths to water in wells completed in unconsolidated deposits usually are less than 50 feet. Depths to water for wells completed in bedrock normally are less than 500 feet and are much less for wells in shallow bedrock in areas of substantial precipitation. Some wells completed in bedrock are as deep as 2,000 feet and derive water from deep flow systems.

The most productive wells in Area 58 are completed in unconsolidated deposits including alluvium, gravel, landslide deposits, terrace deposits, and glacial deposits. Yields of wells completed in these deposits normally are greater than 10 gallons per minute and range from 1 to 750 gallons per minute. Wells completed in glacial deposits generally have smaller yields than wells completed in other unconsolidated deposits. Unconsolidated deposits are usually the most recent geological deposits and typically are more permeable than consolidated rock because this type of rock has not been compacted, cemented, or metamorphosed.

Wells completed in bedrock where there are no unconsolidated deposits are found at higher elevations above river and stream valleys. Wells completed in these consolidated rocks typically yield from 1 to 60 gallons per minute. Depths to water in wells completed in consolidated rock vary from above land surface for flowing artesian wells to greater than 1,000 feet. The ability of bedrock to transmit water is dependent on rock lithology and structure. Sandstones and other fractured rock transmit relatively more ground water than unfractured shales and siltstones.

Wells that are completed in the coal-bearing Mesaverde Group typically yield less water than wells completed in unconsolidated deposits because the forma- tion consists of interbedded mudstones, shales, coal, and fine- to medium-grained sandstones, that are less permeable. Wells completed in the Mesaverde Group average about 9 gallons per minute and range from 1 to 18 gallons per minute. Sandstone and coal strata are the most permeable zones. Coal beds often are fractured. Initial fracture patterns are formed during coal formation and developed further by subsequent tectonic movement and weathering. Dewatering mines is not difficult during coal mining in the Mesaverde Group because of the typically limited permeability of the rock.

Wells also are completed in Eagle Valley Evaporite, Maroon Formation, Burro Canyon Formation, Dakota Sandstone, Mancos Shale, Green River Formation, Precambrian rock, and basalt units. Yields of wells completed in these units average about 18 gallons per minute and range from 1 to 80 gallons per minute.

Information for more than 500 wells inventoried by the U.S.Geological Survey (fig. 6.1-1) is available from the National Water-Data Exchange (NAWDEX) and the National Water-Data Storage and Retrieval System (WATSTORE), described in sections 8.2 and 8.3 of this report. Well data include well depths, yields, construction, locations, water-quality analyses, geologic logs, and other information. Most of the well data are for wells completed in unconsolidated deposits because these deposits occur at lower elevations in areas of greater land development and the wells need less drilling depth.

Regional ground-water flow directions are similar to surface-water flow directions. Recharge occurs in mountainous terrain generally in the eastern part of Area 58 and discharges in lower topographic terrain generally in valleys and in the western part of Area 58. For this reason, the most productive wells generally are in valleys. The Grand Valley, located approximately between Rifle and Grand Junction, is a discharge area as indicated by evaporites deposited at land surface from evaporated ground water (see photograph in fig. 6.1-1).

Clusters of well data shown in figure 6.1-1 are where ground-water studies have been done (see section 6.2). Nearly all wells shown in the figure as completed in the Mesaverde Group are associated with mining areas. 
- Wells completed in unconsolidated deposits including a combination of alluvium, gravels, glacial deposits, landslide deposits, and terrace deposit

- Wells completed in coal-bearing rock units includin the Mesaverde Group, Williams Fork Formation, and Iles Formation

Wells completed in other consolidated rock units
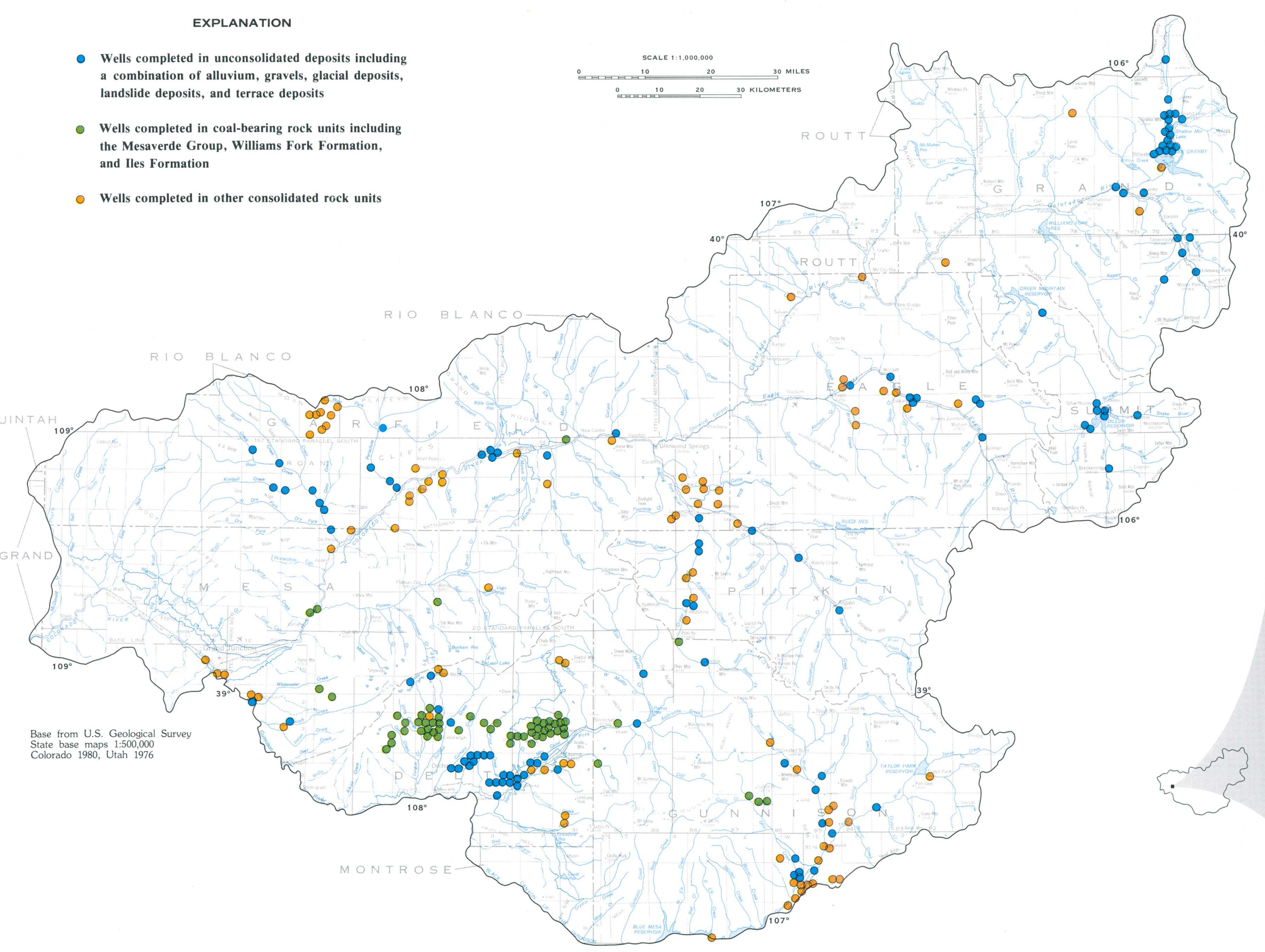

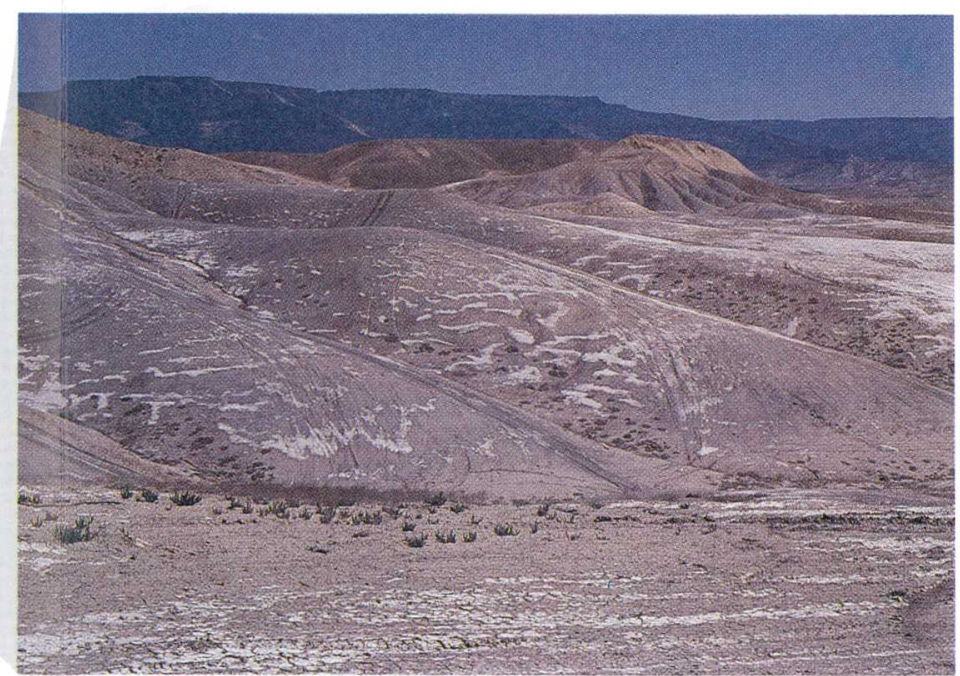

Evaporite (white) deposited by evaporating ground-water discharge near Grand Junction, Colorado. 


\title{
6.0 GROUND WATER--Continued \\ 6.2 Ground-Water Studies
}

\section{Recent Studies Provide Most of the Ground-Water Data}

\author{
Studies range from general ground-water reconnaissances \\ to a mathematical ground-water model.
}

More than 90 percent of well data available from the U.S. Geological Survey for Area 58 were collected in various ground-water studies from 1965 to the present (1984). Report titles or project titles are given in the explanation for figure 6.2-1, and the corresponding study areas are outlined in figure 6.2-1.

General aquifer characteristics are summarized in this section based on previous groundwater studies. Unconsolidated deposits typically transmit the most ground water in the study areas. The water quality in these aquifers normally is better than in underlying bedrock aquifers, although discharge from a hydrologically interconnected bedrock aquifer can contaminate the unconsolidated aquifers. Bedrock aquifers described by the available studies include the Wingate Sandstone, Entrada Sandstone, Burro Canyon Formation, Dakota Sandstone, Mesaverde Group, upper part of Green River Formation, Uinta Formation, Coalmont Formation, and basalts. Aquifers exist in more permeable bedrock units such as the sandstones and in fracture zones. Fractured coal-bed aquifers in the Mesaverde Group often are bounded above and below by unfractured and relatively impermeable shales. Impermeable bedrock such as shales, mudstones, siltstones, and fine-grained sandstones are considered aquitards and confine ground water within underlying bedrock. The Mancos Shale is a common aquitard in the lower western valleys. Wells drilled through the Mancos Shale and into the underlying Dakota Sandstone (or deeper bedrock) cause the water level in the well to rise above where water initially is found during drilling. In some instances, the water level even rises above land surface. These artesian conditions are caused by the high static head within an aquifer confined by an overlying aquitard. Other relatively impermeable geologic strata include unfractured Precambrian rock, the Chinle Formation, Morrison Formation, Benton Shale, Niobrara Formation, Pierre Shale, upper part of Mesaverde Group, lower part of Green River Formation, and the Mahogany zone of the upper part of Green River Formation.

Study areas $2,3,5,6,8,10$, and 11 shown in figure 6.2-1 have coal deposits that have been, are being, or could be mined. The report discussing area 5 indicates that ground water from valley-fill deposits could be used to help meet surface-water minimum-flow requirements if the hydraulic removal of coal was initiated. The report discussing area 8 describes potential subsidence effects on two ephemeral streams that would overlie an expanding underground coal mine. The report discussing area 7 describes the development of a three-dimensional ground-water model for the $\mathrm{Pi}$ ceance basin based on aquifer testing of the Green River Formation. 


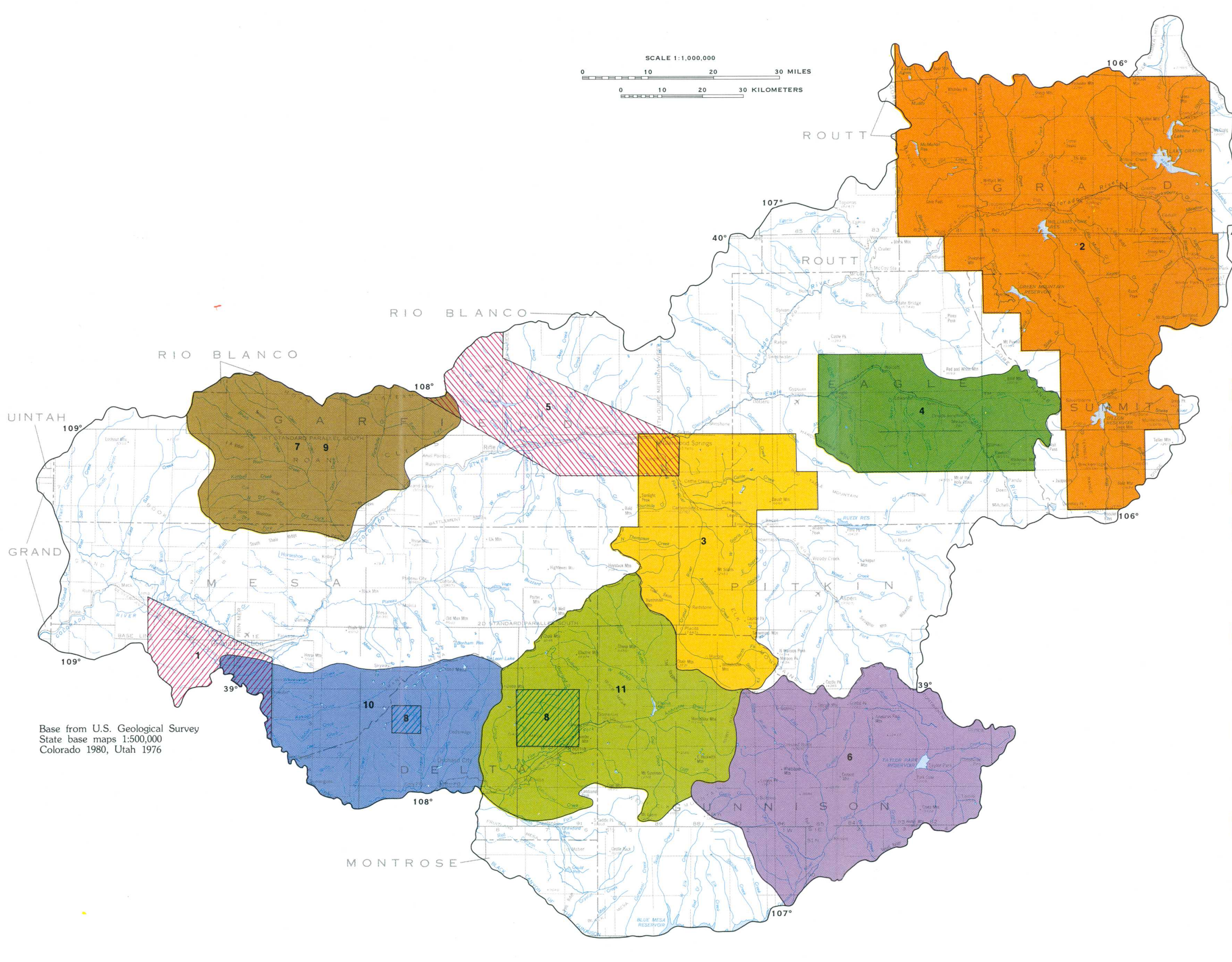




\title{
7.0 GROUND-WATER QUALITY \\ 7.1 Dissolved Solids, $\mathrm{pH}$, and Chemical Composition
}

\section{Chemical Characteristics are Diverse}

\author{
Large concentrations of dissolved solids are common \\ for wells completed in bedrock formations.
}

\begin{abstract}
Water-quality data from wells completed in the Quaternary deposits, Green River Formation, Mancos Shale, Mesaverde Group, and other bedrock units are summarized in figure 7.1-1. These five data groups represent the geologic units that have the most available ground-water chemical data. The chemical data within each unit are diverse. The averages in each data group normally are biased because water samples were collected for specific study areas and do not necessarily represent the entire geologic unit. Most often sample collection was concentrated in specific study areas as described in section 6.2 of this report.
\end{abstract}

Wells completed in bedrock commonly exceed the U.S. Environmental Protection Agency's (1982b) recommended public drinking-water standards for dissolved solids. Large dissolved-solids concentrations in ground and surface waters also can make them unsuitable for irrigation. The upper Colorado River receives discharge of ground water containing substantial dissolved-solids concentrations. Much of this saline ground water is introduced into the river by springs near Dotsero and Glenwood Springs. The probable source of the salinity is the Leadville Limestone and the Dakota Sandstone (URS Corporation, 1981). Ground-water-quality characteristics of bedrock aquifers can affect unconsolidated deposit aquifers when they are interconnected. The result is that the unconsolidated aquifers reflect local bedrock waterquality characteristics. Ground-water characteristics differ in western Colorado drainage basins because groundwater flow paths in different areas are through different geologic units, and flow-system characteristics such as flow path lengths vary. Longer flow paths and denser rock result in greater travel times that provide a greater opportunity for ground water to dissolve and transport minerals. These conditions exist for the Mancos Shale, Mesaverde Group, and the Green River Formation. These units often have greater depths to water in wells, which also indicate longer ground-water flow paths.

Wells completed in Quaternary (unconsolidated) deposits typically have the smallest dissolved solids concentrations in water samples, although some samples exceeded recommended standards (U.S. Environmental Protection Agency, 1982b) for nitrate, and sulfate, and mandatory standards (U.S. Environmental Protection Agency, 1982a) for fluoride. There commonly is an interconnection with bedrock units that statistically creates a wide range of ground-water characteristics in unconsolidated deposits. The major water-quality constituents commonly are calcium, bicarbonate, and sulfate. The major anion, bicarbonate or sulfate, is dependent on the effects of local bedrock.

Wells completed in the Green River Formation commonly exceed the mandatory public-drinking water standard for fluoride but otherwise have relatively small concentrations of dissolved constituents. The major waterquality constituents commonly are sodium and bicarbonate.

Wells completed in the Mesaverde Group commonly exceed the mandatory public drinking-water standard for fluoride and occasionally exceed the recommended limit for chloride. Coal mining in this formation alters natural ground-water quality because ground water flows through spoil piles and exposed mine cuts and discharges from underground mine portals. Major ground-water-quality constituents commonly are sodium and bicarbonate.

Wells completed in the Mancos Shale have the least potential for suitable quantity and quality of water. The Mancos Shale is a thick marine shale and contains a large quantity of soluble minerals. Ground-water flow is impeded in the dense shale, which increases traveltime and provides a greater opportunity for mineral dissolution as evidenced by its having the largest concentration of dissolved solids of the five geologic units shown in figure 7.1-1. Wells completed in this formation commonly exceed the recommended drinking-water standards for sulfate and the mandatory limits for fluoride. Chloride occasionally exceeds the recommended drinking-water standard (U.S. Environmental Protection Agency, 1982b). These water-quality characteristics explain the limited past and present development of ground-water sources in the Mancos Shale. The major water-quality constituents commonly are sodium and sulfate.

Wells completed in other bedrock units from which water samples have been obtained include Precambrian rock, Maroon Formation, Morrison Formation, Entrada Sandstone, Dakota Sandstone, Pierre Shale, Middle Park Formation, and other undifferentiated units. 

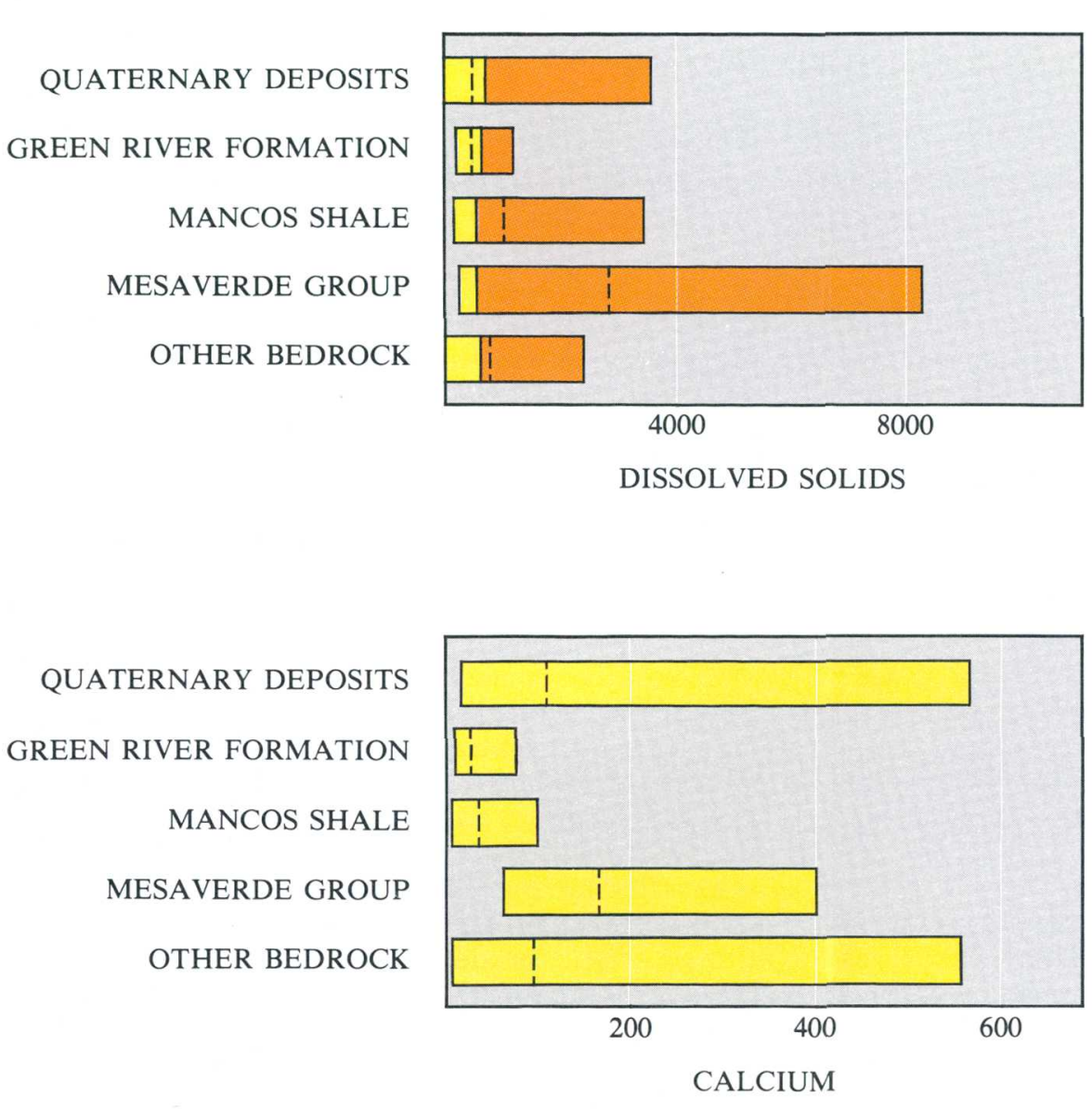

QUATERNARY DEPOSITS GREEN RIVER FORMATION MANCOS SHALE MESAVERDE GROUP OTHER BEDROCK

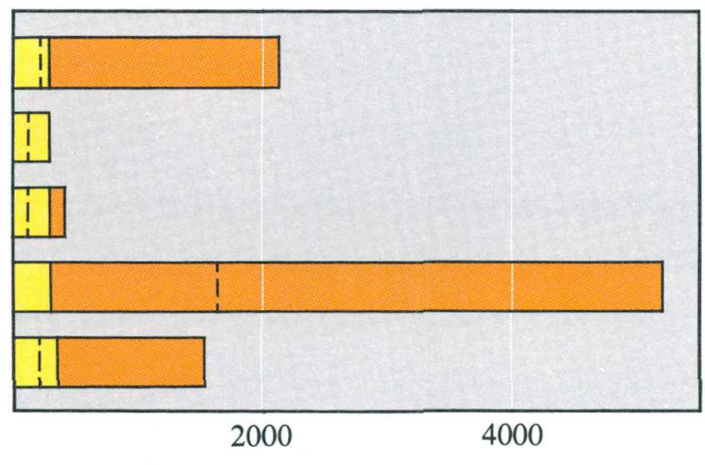

SULFATE

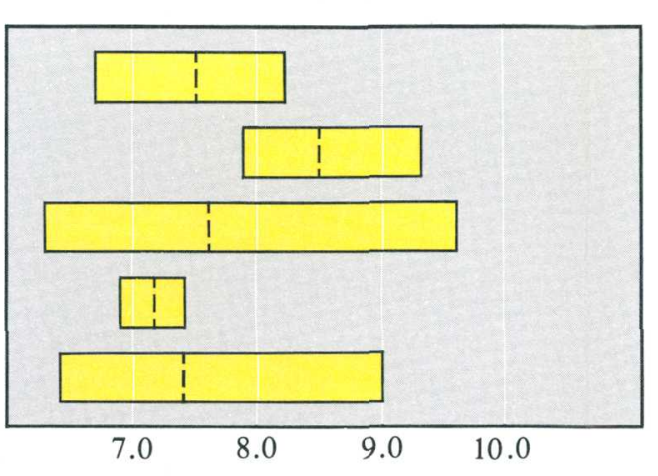

$\mathrm{pH}$

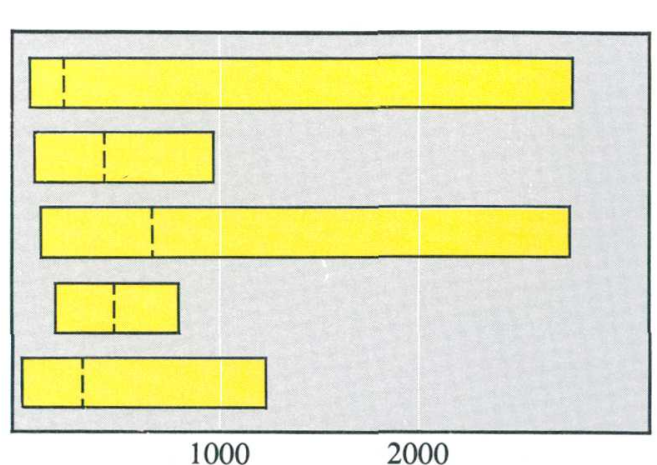

ALKALINITY AS CALCIUM CARBONATE
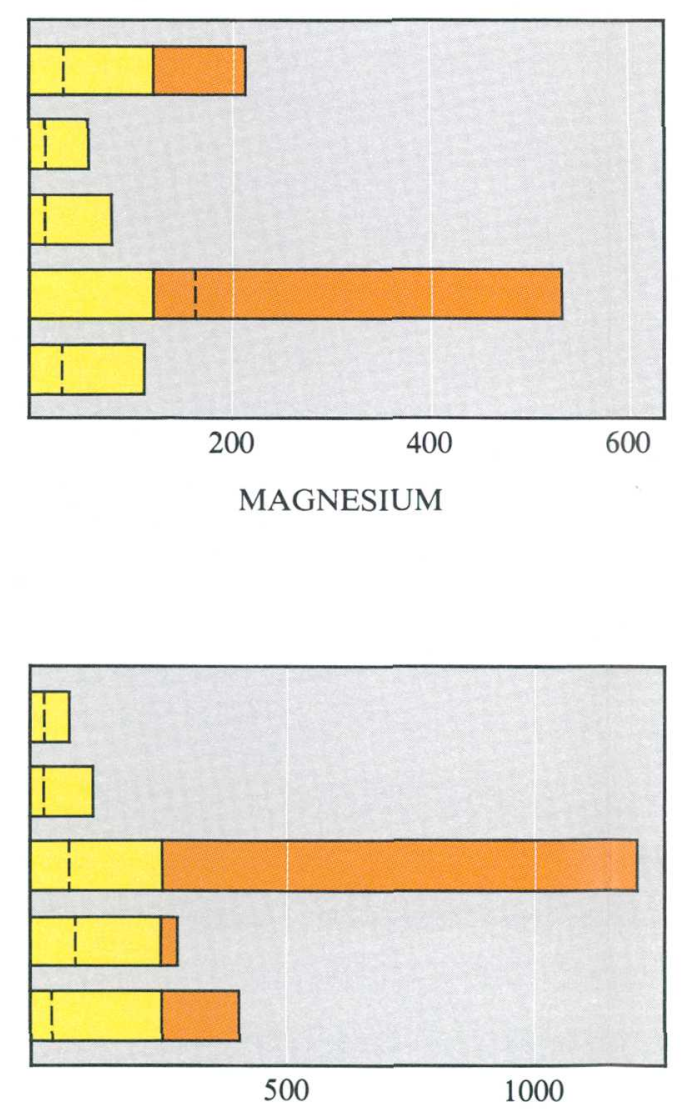

CHLORIDE
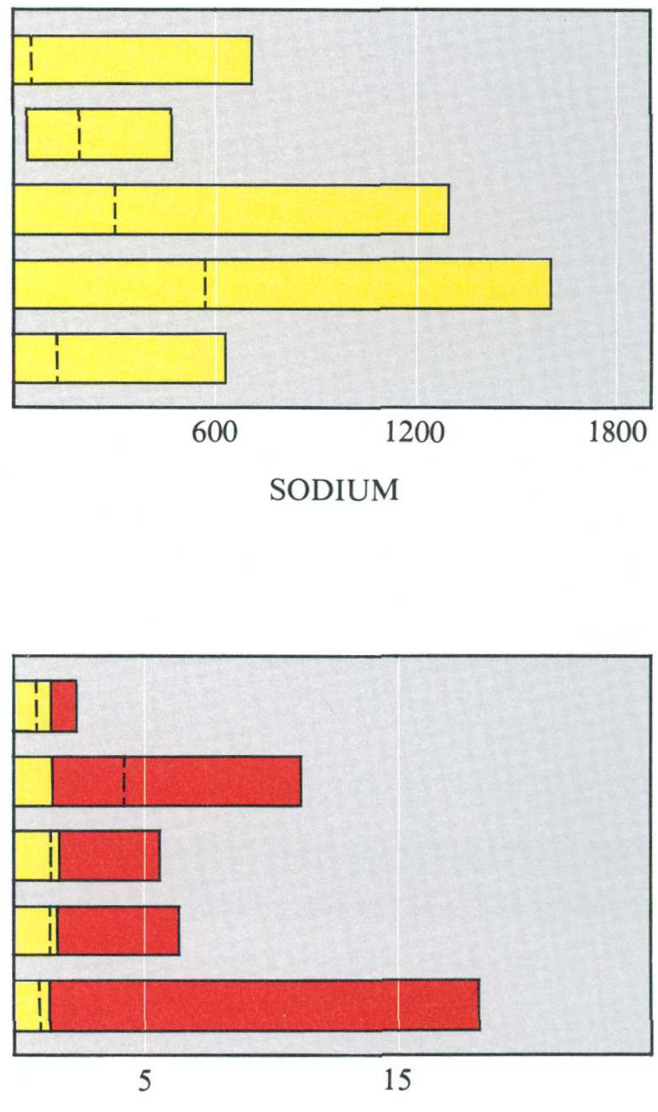

FLUORIDE

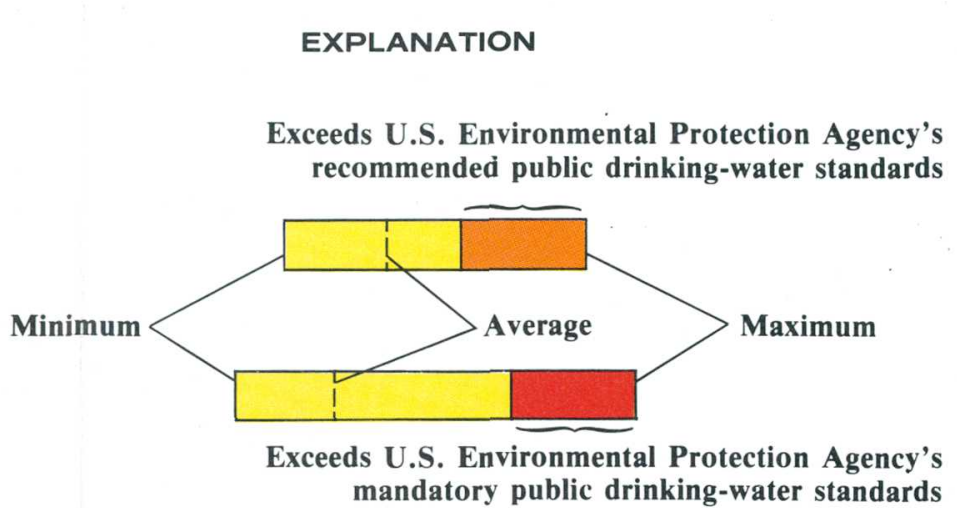

ALL CONCENTRATIONS IN MILLIGRAMS PER LITER EXCEPT FOR pH WHICH IS UNITLESS.
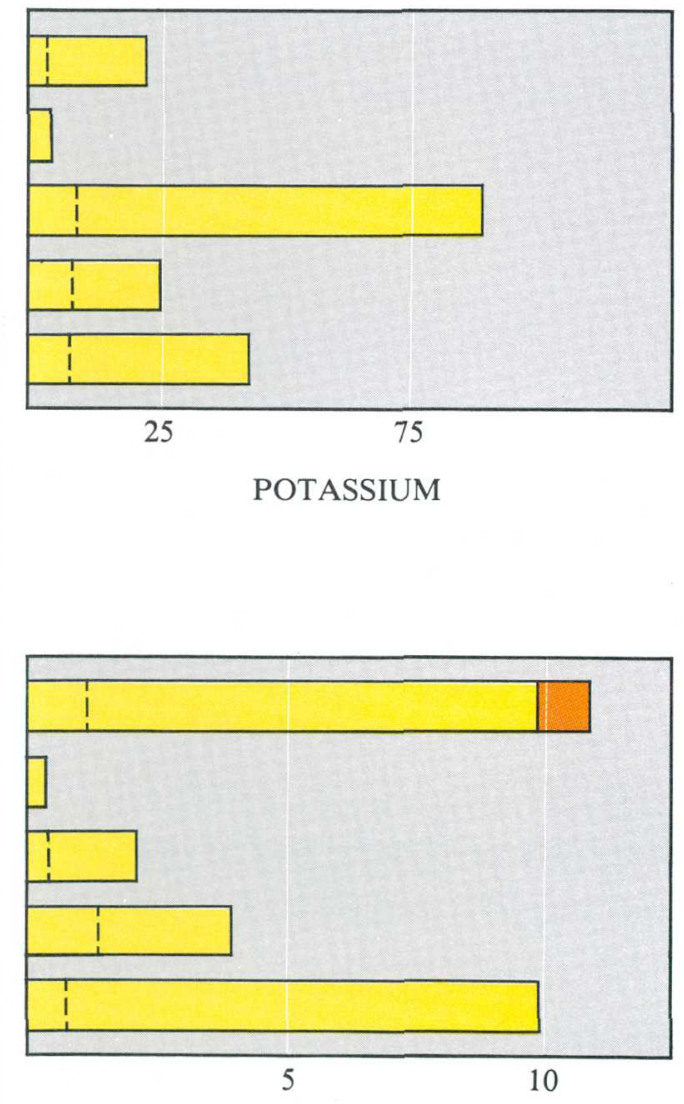

NITRITE AND NITRATE AS NITROGEN 


\title{
7.0 GROUND-WATER QUALITY--Continued \\ 7.2 Trace Elements
}

\section{Trace-Element Concentrations Have Wide Ranges}

\author{
Large concentrations of iron and manganese \\ are common in well water samples.
}

Data for water-sample analyses from wells completed in Quaternary (unconsolidated) deposits, the Green River Formation, the Mesaverde Group, and other bedrock units are summarized in figure $7.2-1$. These groups represent geologic units for which the most water-quality data are available. Trace elements have broad ranges in concentration because sampling was done throughout a large area. Trace-element concentrations are summarized only for geologic units for which sufficient data are available. Most ground waters sampled were within the U.S. Environmental Protection Agency's (1982b, 1982a) recommended and mandatory drinking-water standards, although concentrations of iron and manganese typically are large.

Unconsolidated deposits generally contain smaller trace-element concentrations than bedrock aquifers. A hydrological interconnection with a bedrock aquifer can degrade an aquifer in unconsolidated deposits. However, some water samples obtained from wells completed in unconsolidated deposits exceeded the mandatory public drinkingwater standard for selenium and recommended standards for iron and manganese. All water samples from wells completed in the Green River Formation were obtained in west-central Garfield County and were related to oil-shale studies. These wells typically were deeper than 500 feet, and water samples commonly exceeded the mandatory public-drinking-water standard for arsenic. Water samples obtained from wells completed in the Mesaverde Group sometimes exceeded the mandatory drinking-water standard for barium, chromium, and selenium. Wells typically were deeper than 1,000 feet. Some water samples obtained from wells completed in other bedrock units (Dakota Sandstone, Mancos Shale, and other undifferentiated units) exceeded the mandatory public-drinking-water standard for selenium.

Excessive concentrations of iron in drinking water cause a metallic taste, and excessive iron and manganese concentrations cause precipitation and staining of surfaces. Ground water from wells completed in bedrock aquifers may be unsuitable for irrigation because of boron concentrations larger than 1,000 micrograms per liter. Boron concentrations generally increase with well depth and are characteristic of deep wells completed in the Mesaverde Group and Green River Formation.

Coal mining can be the source of surface- and ground-water contamination. Spoil piles and coal stock piles used in mining expose the spoils and coal to oxidation. Pyrite sometimes is associated with coal deposits and, when exposed at land surface, can be oxidized and produce sulfuric acid. Acidic waters can dissolve and transport trace elements in addition to soluble calcium, magnesium, sodium, and sulfate from spoil piles and coal stock piles. Effluent from these piles can enter surface- or ground-water systems. 
QUATERNARY DEPOSITS

GREEN RIVER FORMATION

MESAVERDE GROUP

OTHER BEDROCK
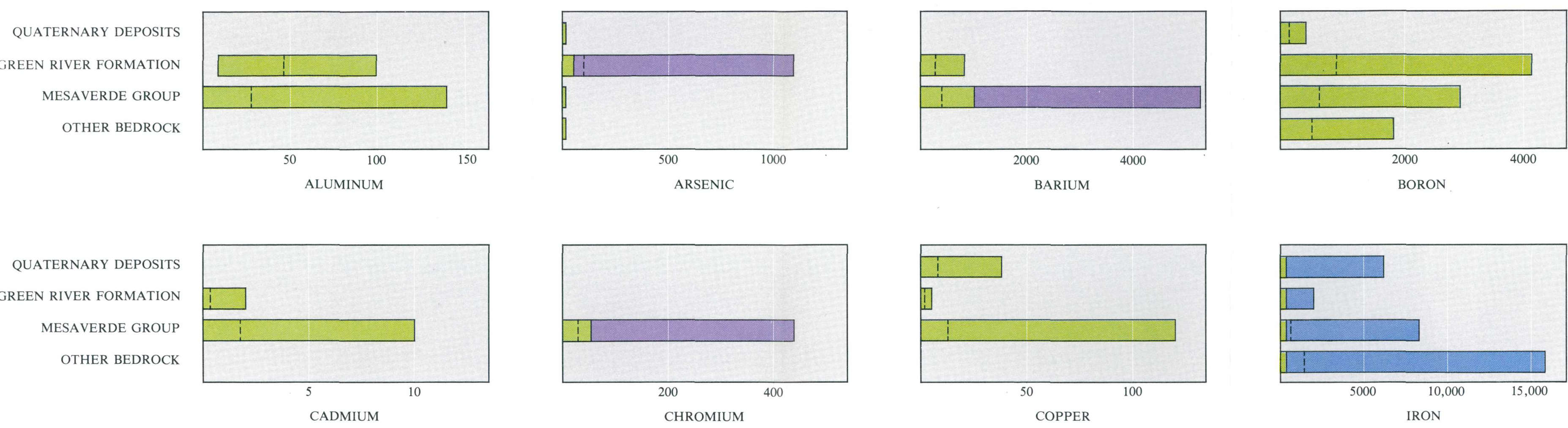

QUATERNARY DEPOSITS GREEN RIVER FORMATION

MESAVERDE GROUP OTHER BEDROCK

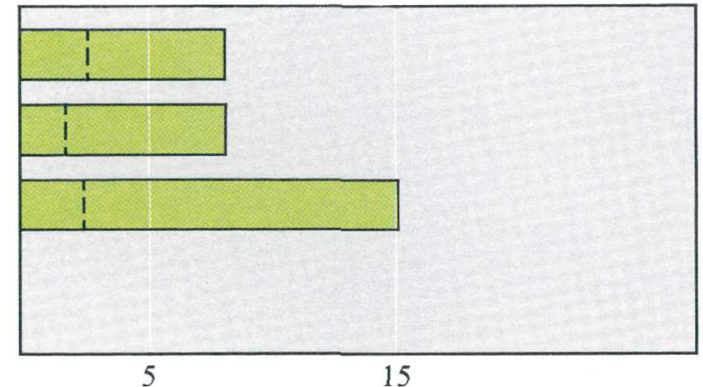

LEAD

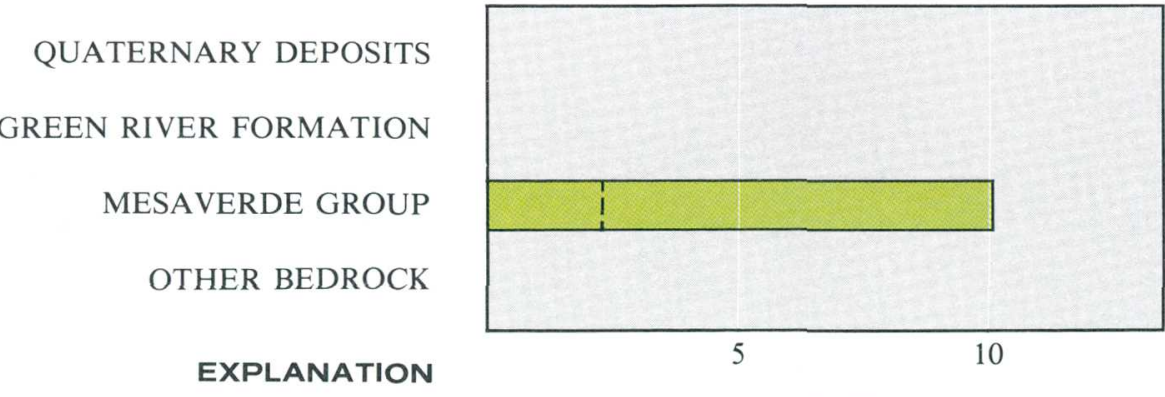

Exceeds U.S. Environmental Protection Agency's

NICKEL
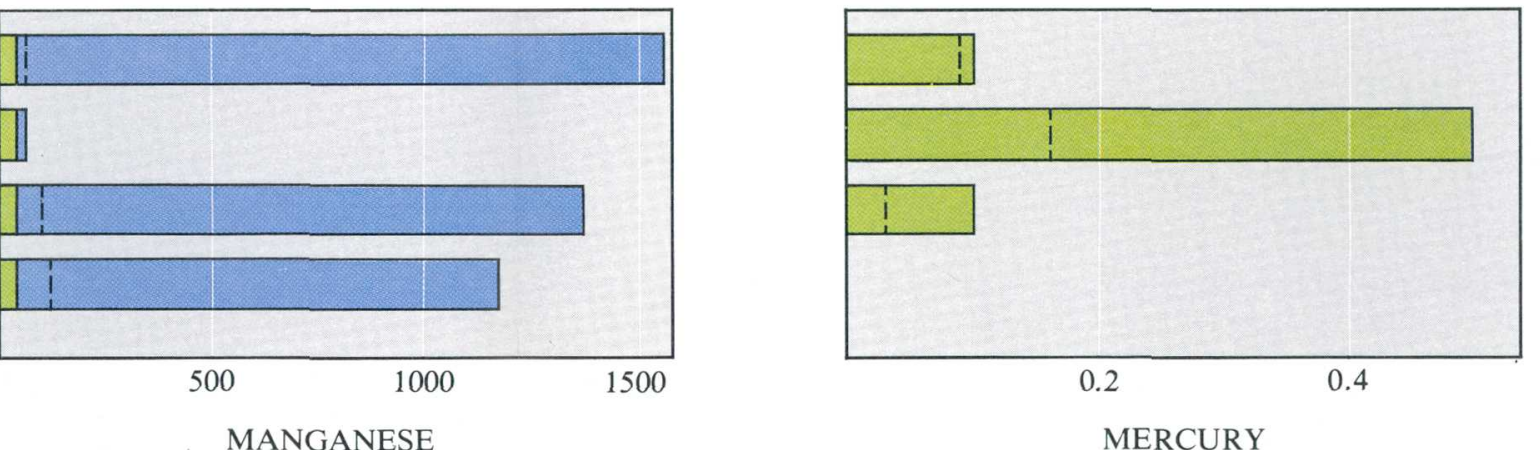

MERCURY

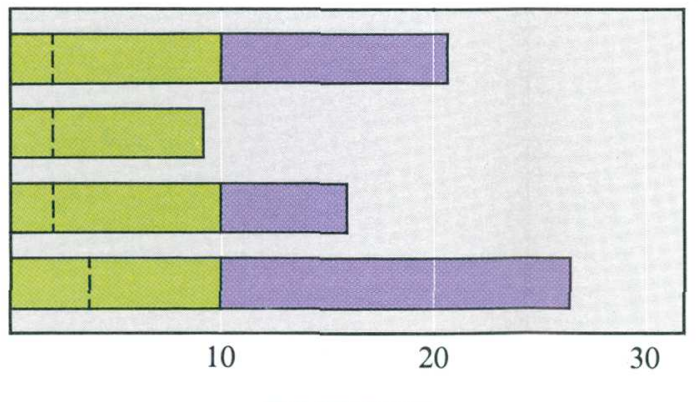

SELENIUM

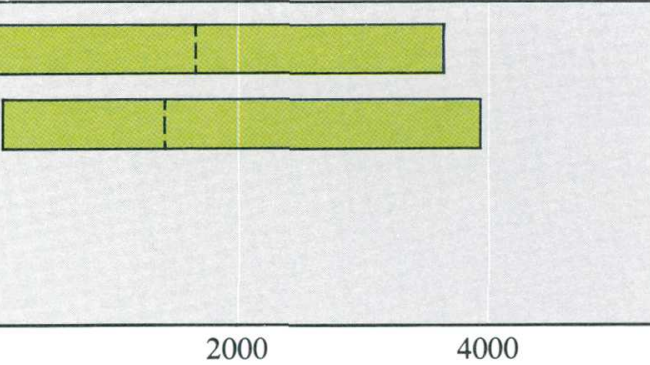

STRONTIUM
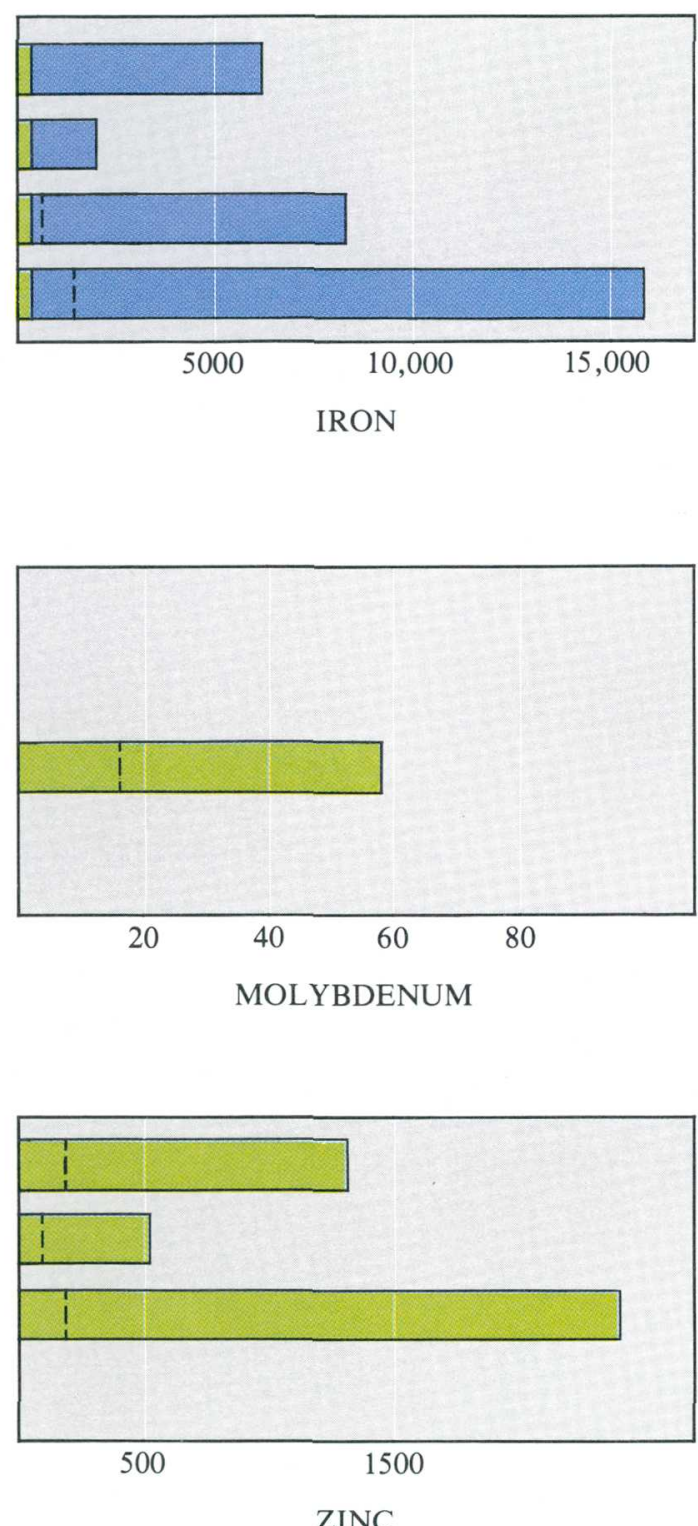

Figure 7.2-1 Dissolved trace-elements of water samples taken from wells completed in different geologic units.

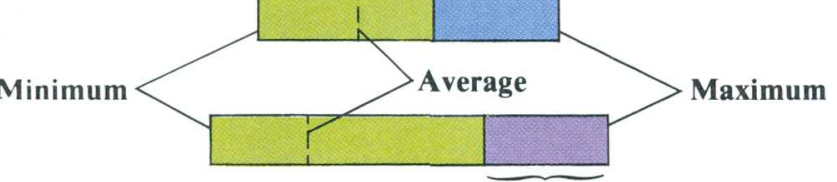

Exceeds U.S. Environmental Protection Agency's

mandatory public drinking-water standards

ALL CONCENTRATIONS IN MICROGRAMS PER LITER
7.0 GROUND-WATER QUALITY--Continued 7.2 Trace Elements 
. 


\title{
8.0 WATER-DATA SOURCES \\ 8.1 Introduction
}

\section{NAWDEX, WATSTORE, OWDC Have Water-Data Information}

\author{
Water data are collected in coal areas by a large number of organizations for \\ a wide variety of missions and needs.
}

Within the U.S. Geological Survey there are three activities that help to identify and improve access to the vast amount of existing water data.

1. The National Water-Data Exchange (NAWDEX) indexes the water data available from over 400 organizations and serves as a central focal point to help those in need of water data by identifying information already available.

2. The National Water-Data Storage and Retrieval System (WATSTORE) serves as the central repository of water data collected by the U.S. Geological Survey and contains large volumes of data on the quantity and quality of both surface and ground waters.

3. The Office of Water-Data Coordination (OWDC) coordinates Federal water-data acquisi- tion activities and maintains a "Catalog of Information on Water Data." To assist in identifying available water-data activities in coal provinces of the United States, special indexes to the Catalog are being printed and made available to the public.

In addition to U.S. Geological Survey waterdata activities, the U.S. Environmental Protection Agency operates a data base called the Water Quality Control Information System (STORET). This data base is used for the storage and retrieval of data relating to the quality of waterways within and contiguous to the United States.

A more detailed explanation of these three activities is given in sections 8.2, 8.3, 8.4, and 8.5. 


\title{
8.0 WATER-DATA SOURCES--Continued \\ 8.2 National Water-Data Exchange (NAWDEX)
}

\section{NAWDEX Simplifies Access to Water Data}

\author{
The National Water-Data Exchange (NAWDEX) is a nationwide program managed by \\ the U.S. Geological Survey to assist users of water data or water-related \\ data in identifying, locating, and acquiring needed data.
}

NAWDEX is a national confederation of wateroriented organizations working together to make their data more readily accessible and to facilitate a more efficient exchange of water data.

Services are available through a Program Office at the U.S. Geological Survey's National Center in Reston, Va. and a nationwide network of Assistance Centers in 45 States and Puerto Rico, which provide local and convenient access to NAWDEX facilities. (See fig. 8.2-1.) A directory, which is available on request, provides names of organizations and persons to contact and addresses, telephone numbers, and office hours for each of the organizations [Directory of Assistance Centers of the National Water Data Exchange (NAWDEX), U.S. Geological Survey Open-File Report 80-1193].

NAWDEX can assist any organization or individual in identifying and locating needed water data and can refer the requester to the organization that retains the data required. To provide this service, NAWDEX maintains a computerized Master Water-Data Index (fig. 8.2-2), which identifies sites for which water data are available, the type of data available for each site, and the organization retaining the data. A Water-Data Sources Directory (fig. 8.2-3), which also is maintained, identifies organizations that are sources of water data and the locations within these organizations from which data may be obtained. In addition, NAWDEX has direct access to large water-data bases of some of its members and has reciprocal agreements for the exchange of services with others.

Charges for NAWDEX services are assessed at the option of the organization providing the requested data or data service. Search-assistance services are provided free by NAWDEX to the greatest extent possible. Charges are assessed, however, for those requests requiring computer cost, extensive personnel time, duplicating services, or other costs encountered by NAWDEX in the course of providing services. In all cases, charges assessed by NAWDEX Assistance Centers will not exceed the direct costs incurred in responding to the data request. Estimates of cost are provided by NAWDEX upon request and in all cases where costs are anticipated to be substantial.

For additional information concerning the NAWDEX program or its services contact:

$$
\text { Program Office }
$$

National Water-Data Exchange (NAWDEX)

U.S. Geological Survey

421 National Center

12201 Sunrise Valley Drive

Reston, VA 22092

Telephone: (703)860-6031 FTS 928-6031

Hours 7:45 a.m. to 4:15 p.m. Eastern Time

or

\section{COLORADO}

U.S. Geological Survey

Water Resources Division MS 415 Box 25046

Denver Federal Center

Lakewood, CO 80225 


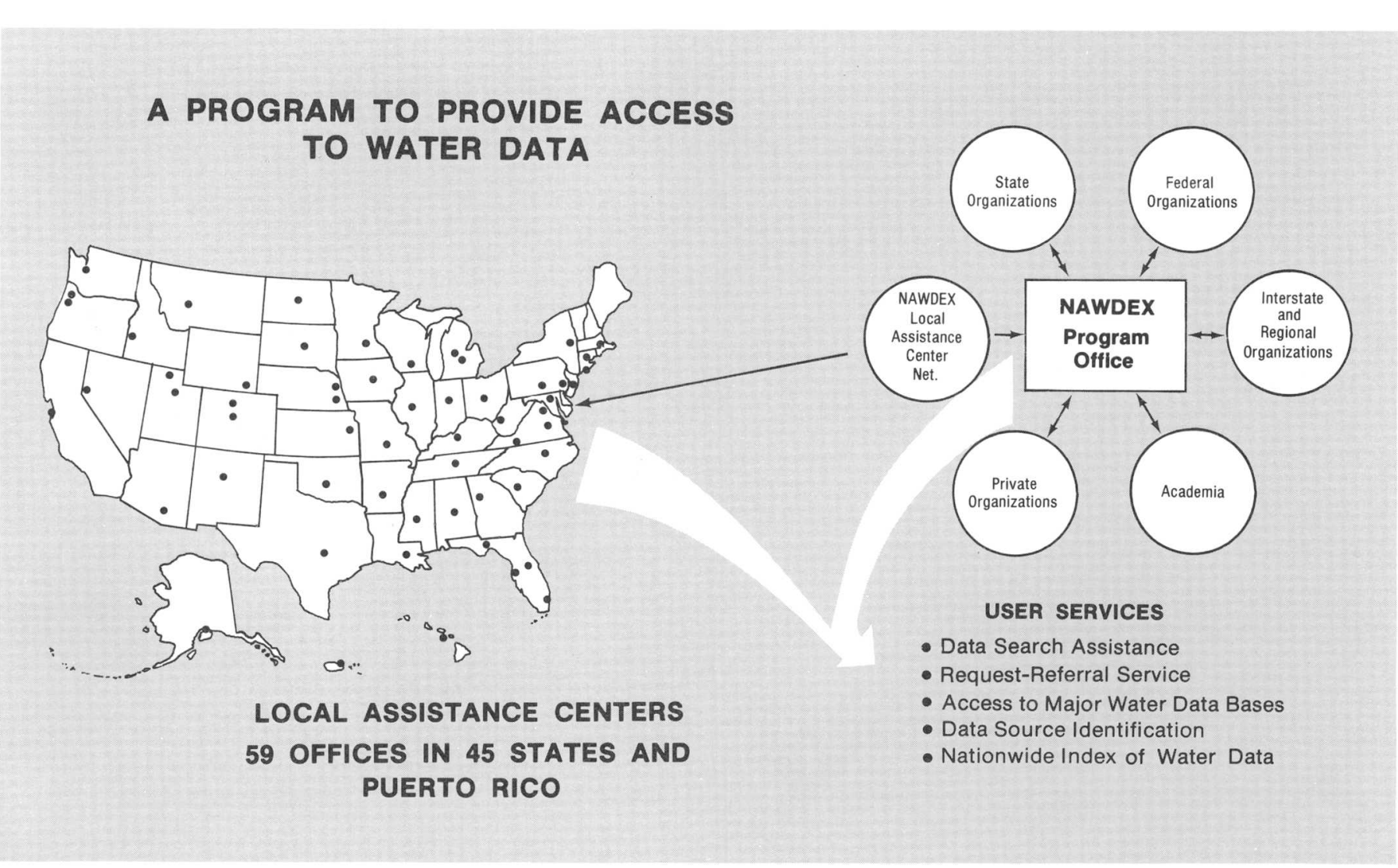

Figure 8.2-1 Access to water data.
MASTER WATER-DATA INDEX

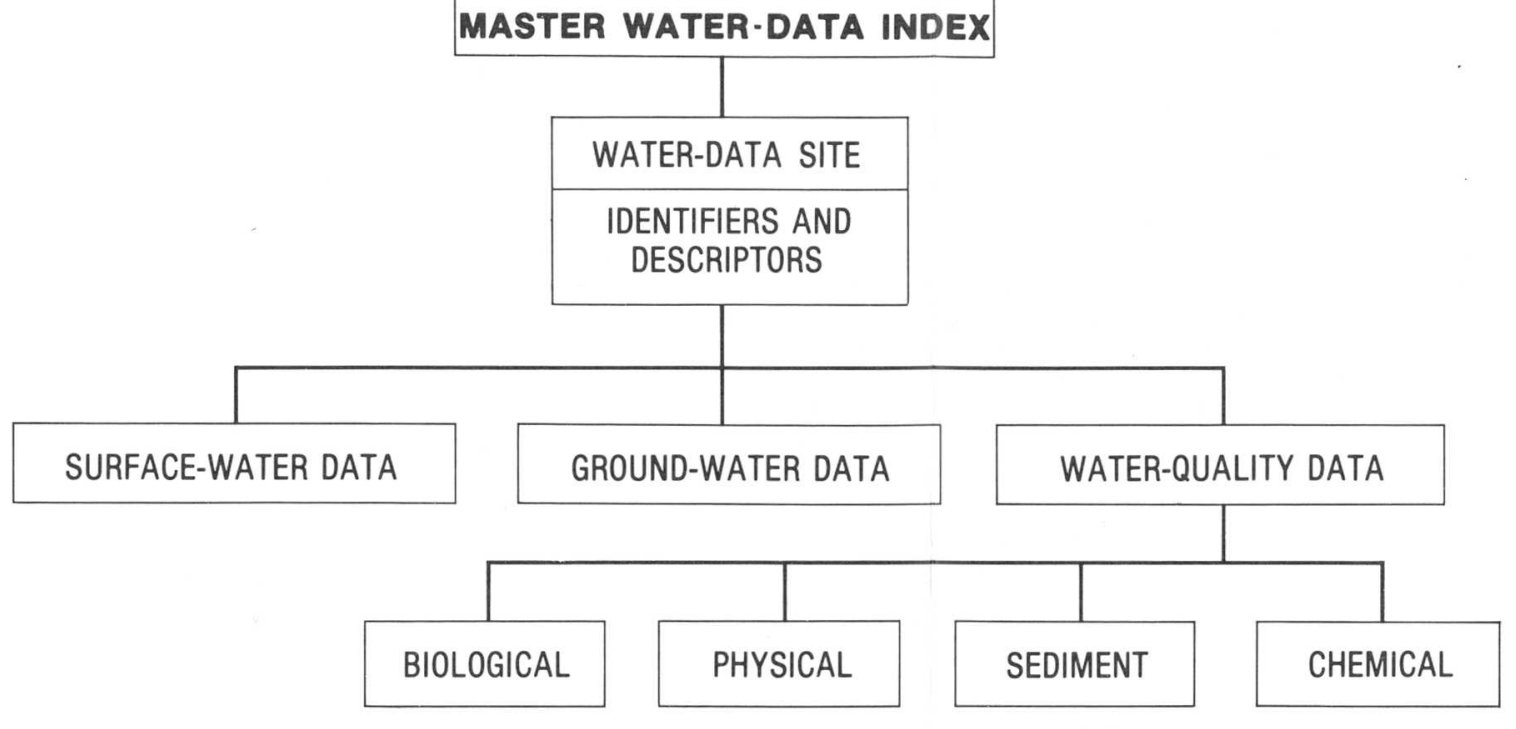

Figure 8.2-2 Master Water-Data Index.

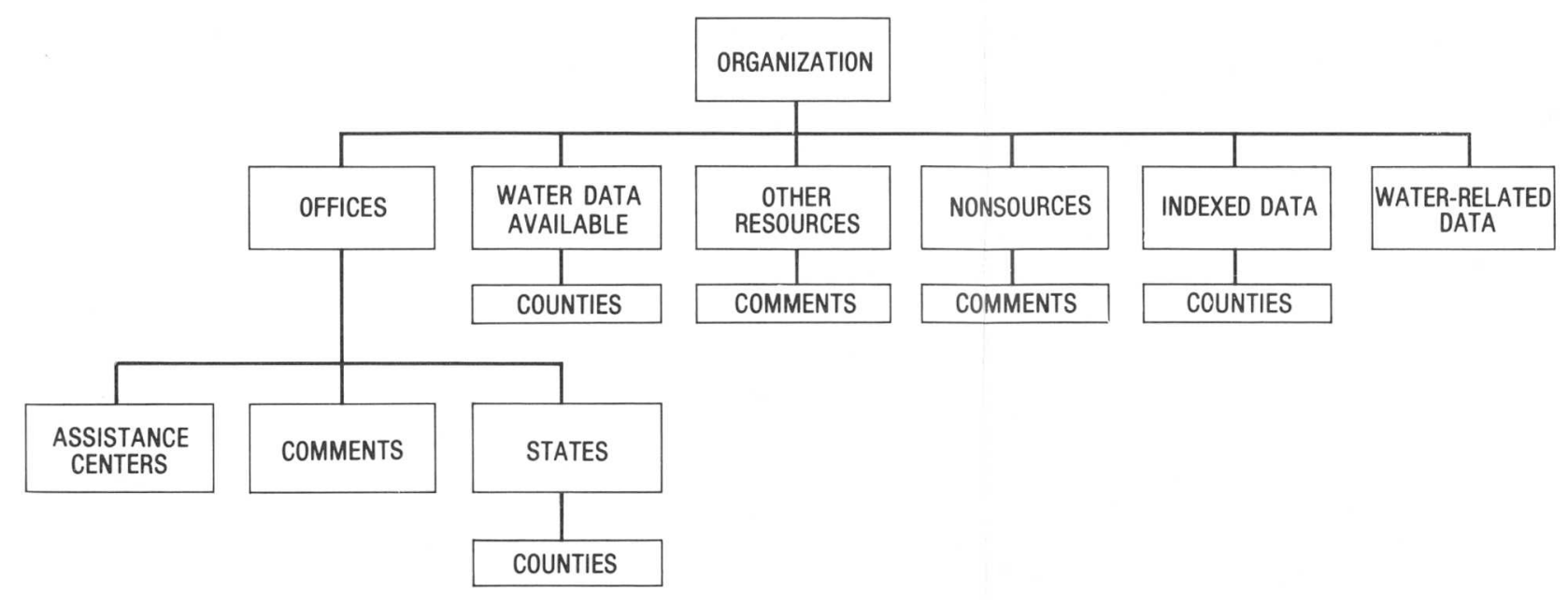

Figure 8.2-3 Water-Data Sources Directory. 


\title{
8.0 WATER-DATA SOURCES--Continued 8.3 WATSTORE
}

\section{WATSTORE Automated Data System}

\author{
The National Water-Data Storage and Retrieval System (WATSTORE) of the \\ U.S. Geological Survey provides computerized procedures and \\ techniques for processing water data and provides effective \\ and efficient management of data-releasing activities.
}

The National Water-Data Storage and Retrieval System (WATSTORE) was established in November 1971 to computerize the U.S. Geological Survey's existing water-data system and to provide for more effective and efficient management of its data-releasing activities. The system is operated and maintained on the central computer facilities of the Survey at its National Center in Reston, Virginia. Data may be obtained from WATSTORE through the Water Resources Division's 43 district offices. General inquiries about WATSTORE may be directed to:

Chief Hydrologist

U.S. Geological Survey

437 National Center

Reston, VA 22092

or

District Chief

U.S. Geological Survey

Water Resources Division

MS 415 Box 25046

Denver Federal Center

Lakewood, CO 80225

The Geological Survey currently (1980) collects data nationwide at approximately 16,000 stream-gaging stations, 1,000 lakes and reservoirs, 5,200 surface-water quality stations, 1,020 sediment stations, 30,000 waterlevel observation wells, and 12,500 ground-water quality wells. Each year, many water-data collection sites are added and others are discontinued; thus, large amounts of diversified data, both current and historical, are amassed by the Survey's data-collection activities.

The WATSTORE system consists of several files in which data are grouped and stored by common characteristics and data-collection frequencies. The system also is designed to allow for the inclusion of additional data files as needed. Currently, files are maintained for the storage of: (1) Surface water, quality of water, and ground water measured on a daily or continuous basis; (2) annual peak values for streamflow stations; (3) chemical analyses for surface- and ground-water sites; (4) water parameters measured more frequently than daily; and (5) geologic and inventory data for ground-water sites. In addition, an index file of sites for which data are stored in the system is maintained (fig. 8.3-1). A brief description of each file is as follows:
Station-Header File: Information pertinent to the identification, location, and physical description of nearly 220,000 sites are contained in this file. All sites for which data are stored in the Daily-Values, Peak-Flow, WaterQuality, and Unit-Values Files of WATSTORE are indexed in this file.

Daily-Values File: All water-data parameters measured or observed either on a daily or on a continuous basis and numerically reduced to daily values are stored in this file. Instantaneous measurements at fixed-time intervals, daily mean values, and statistics such as daily maximum and minimum values also may be stored. This file currently contains over 200 million daily values including data on streamflow, river stages, reservoir contents, water temperatures, specific conductance, sediment concentrations, sediment discharges, and groundwater levels.

Peak-Flow File: Annual maximum (peak) streamflow (discharge) and gage height (stage) values at surfacewater sites constitute this file, which currently contains over 400,000 peak observations.

Water-Quality File: Results of more than 1.4 million analyses of water samples are contained in this file. These analyses contain data for as many as 185 different constituents and physical properties that describe the chemical, physical, biological, and radiochemical characteristics of both surface and ground waters.

Unit-Values File: Water parameters measured on a schedule more frequent than daily are stored in this file. Rainfall, stream discharge, and temperature data are examples of the types of data stored in the Unit-Values File.

Ground-Water Site-Inventory File: This file is maintained within WATSTORE independent of the files discussed above, but it is cross-referenced to the WaterQuality File and the Daily-Values File. It contains inventory data about wells, springs, and other sources of ground water. The data included are site location and identification, geohydrologic characteristics, wellconstruction history, and one-time field measurements such as water temperature. The file is designed to accommodate 255 data elements and currently contains data for nearly 700,000 sites.

All data files of the WATSTORE system are maintained and managed on the central computer facility 
of the Geological Survey at its National Center WATSTORE at a number of locations that are part a nationwide telecommunications network.

Remote Job-Entry Sites: Almost all of the Water high-speed computer terminals for remote access to th be entered into or retrieved from the system within an nterval of several minutes to overhight, depending upon the priority placed on the request. The number of
job-entry sites is increased as the need arises.

Digital-Transmission Sites: Digital recorders are used at many field locations to record values temperature, turbidity, wind direction, and chloride concentration. Data are recorded on 16-channel paper tape; the tape is removed from the recorder, and the data are transmitted over telephone lines to the receiver at use on the central computer. Extensive testing of satellite data-collection platforms indicates their feasibility for transmitting realtime hydrologic data on a national munication link to the satellite. About 200 datarelay stations are being operated currently by the Water Resources Division.

Central Laboratory System: The Water Resources Division's water-quality laboratory, located in Denver, Colo., analyzes more than 150,000 water samples per year. This laboratory is equipped to automatically persimple inorganic substances, such as chloride, to complex organic compunds, such as pesticides. As each
analysis is completed, the results are verified by laboratory personnel and transmitted via a computer terminal to the central computer facilities makers for the management, development, and mon- itoring of our water resources. In addition to its data procminimal fee, plus the actual computer cost incurred in

Computer-Printed Tables: Users most often request data from WATSTORE in the form of tables printed by the computer. These tables may contain lists of actual of data stored in the files. A variety of formats is available to display the many types of data.

Computer-Printed Graphs: Computer-printed graphs for the rapid analysis or display of data are another available to produce bar graphs (histograms), line graphs frequency-distribution curves, X-Y point plots, sitelocation-map plots, and other similar items by means of

Statistical Analyses: WATSTORE interfaces with a proprietary statistical package (SAS) to provide extensive analyses of data such as regression analyses,

Digital Plotting: WATSTORE also makes use of software systems that prepare data for digital plotting on peripheral of fline plotters available at the central com hydrographs, frequency-distribution curves, X-Y point plots, contour plots, and three-dimensional plots.

Data in Machine-Readable Form: Data stored in for use on other computers or for use as input to userwritten computer programs. These data are available in the standard format of the WATSTORE system or in the punched cards or card images on magnetic tape.

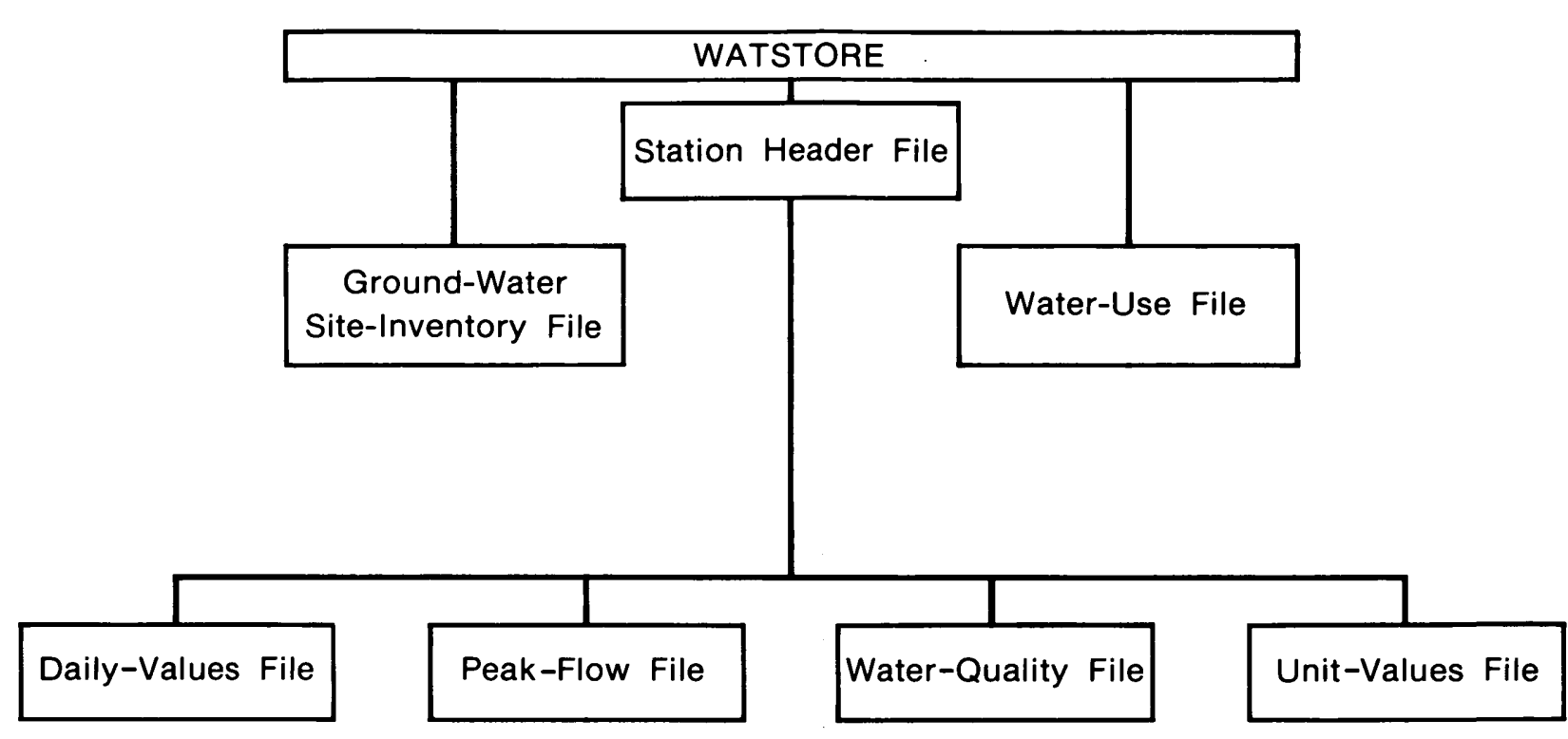

Figure 8.3-1 Index-file stored data. 


\title{
8.0 WATER-DATA SOURCES--Continued \\ 8.4 Index to Water-Data Activities in Coal Provinces
}

\section{Water Data Indexed for Coal Provinces}

\author{
A special index, "Index to Water-Data Activities in \\ Coal Provinces of the United States," has been published by the \\ U.S. Geological Survey's Office of Water-Data Coordination (OWDC).
}

The "Index to Water-Data Activities in Coal Provinces of the United States" was prepared to assist those involved in developing, managing, and regulating the Nation's coal resources by providing information on the availability of water-resources data in the major coal provinces of the United States. It is derived from the "Catalog of Information on Water Data," which is a computerized information file about water-data acquisition activities in the United States and its territories and possessions, with some international activities included.

This special index consists of five volumes (fig. 8.4-1): volume I, Eastern Coal Province; volume II, Interior Coal Province; volume III, Northern Great Plains and Rocky Mountain Coal Provinces; volume IV, Gulf Coast Coal Province; and volume V, Pacific Coast and Alaska Coal Provinces. The information presented will aid the user in obtaining data for evaluating the effects of coal mining on water resources and in developing plans for meeting additional water-data needs. The report does not contain the actual data; rather, it provides information that will enable the user to determine if needed data are available.

Each volume of this special index consists of four parts: Part A, Streamflow and Stage Stations; Part B, Quality of Surface-Water Stations; Part C, Quality of Ground-Water Stations; and Part D,
Areal Investigations and Miscellaneous Activities. Information given for each activity in Parts A-C includes: (1) the identification and location of the station, (2) the major types of data collected, (3) the frequency of data collection, (4) the form in which the data are stored, and (5) the agency or organization reporting the activity. Part D summarizes areal hydrologic investigations and water-data activities not included in the other parts of the index. The agencies that submitted the information, agency codes, and the number of activities reported by type are shown in a table.

Those who need additional information from the Catalog file or who need assistance in obtaining water data should contact the National Water-Data Exchange (NAWDEX). (See section 8.2.)

Further information on the index volumes and their availability may be obtained from:

District Chief

U.S. Geological Survey

Water Resources Division MS415 Box 25046

Denver Federal Center Lakewood, CO 80225 


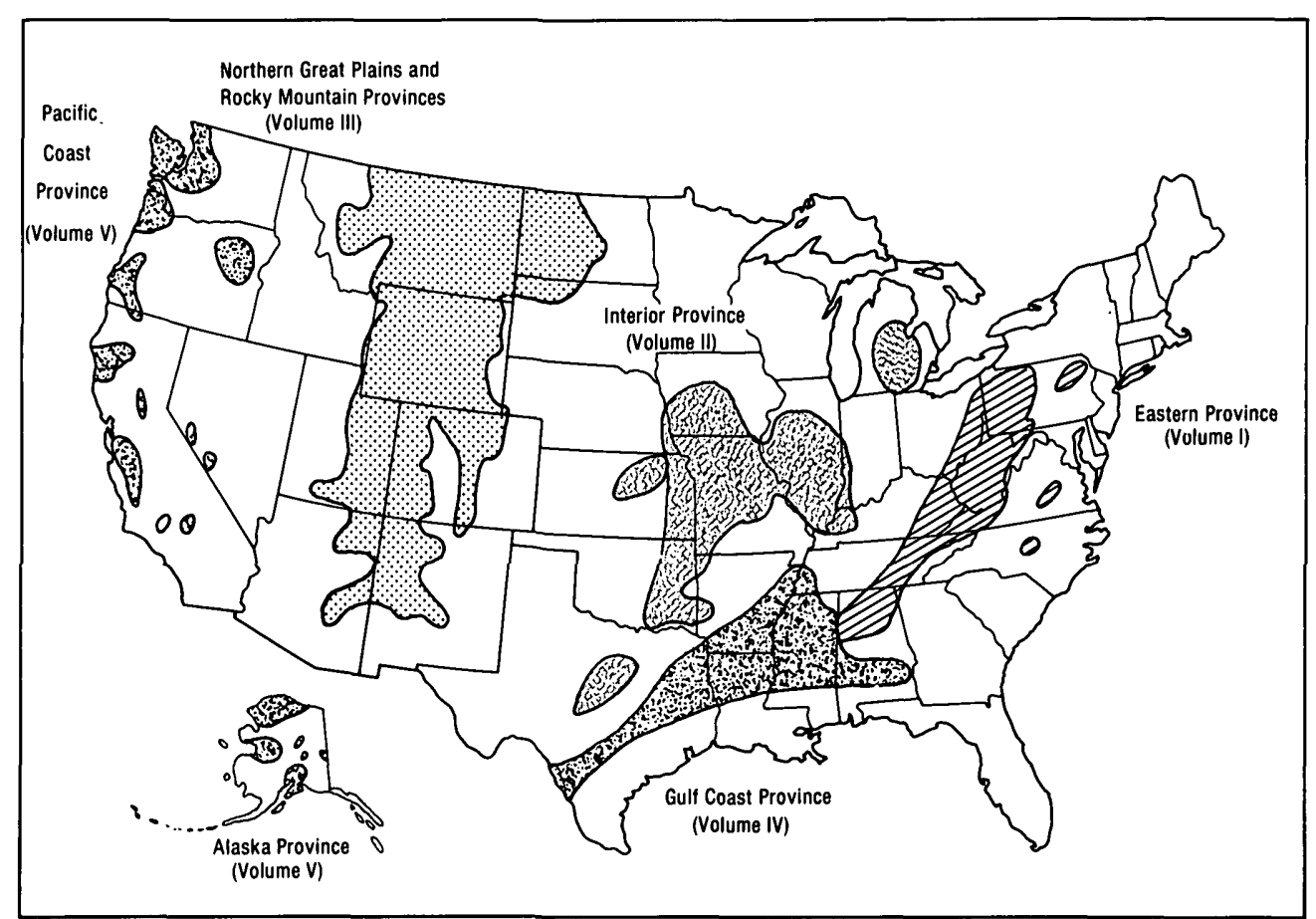

Figure 8.4-1 Index volumes and related provinces. 


\subsection{WATER-DATA SOURCES--Continued \\ 8.5 STORET}

\section{STORET is U.S. Environmental Protection Agency's Computerized Data-Base System}

\section{STORET is the computerized water-quality data-base system maintained by the U.S. Environmental Protection Agency.}

STORET is a computerized data-base system maintained by the U.S. Environmental Protection Agency (1979) for the storage and retrieval of data relating to the quality of the waterways within and contiguous to the United States. The system is used to store data on water quality, water-quality standards, point sources of pollution, pollution-caused fishkills, waste-abatement needs, implementation schedules, and other water-quality related information. The Water-Quality File (WQF) is the most widely used STORET file.

The data in the WQF are collected through cooperative programs involving EPA, State waterpollution-control authorities, and other governmental agencies. The U.S. Geological Survey, the U.S. Forest Service, the U.S. Army Corps of Engineers, the Bureau of Reclamation, and the Tennessee Valley Authority all use STORET's WQF to store and retrieve data collected through their waterquality monitoring programs.

There are 1,800 water-quality parameters defined within STORET's WQF . In 1976 there were data from more than 200,000 unique collection points in the system. Figure 8.5-1 illustrates the groups of parameters and the number of observations that are in the $W Q F$.

State, Federal, interstate, and local government agencies can become STORET users. Information on becoming a user of the system can be obtained by contacting the Environmental Protection Agency. The point of contact for Region $V$ is:

Director

Surveillance and Analysis Division Environmental Protection Agency 1660 Lincoln Street Suite 102 Denver, CO 80295 (303) 837-2226

Source: Handbook Water Quality Control Information System (STORET), U.S. Environmental Protection Agency, Office of Waste and Hazardous Materials, Washington D.C., 20460. 


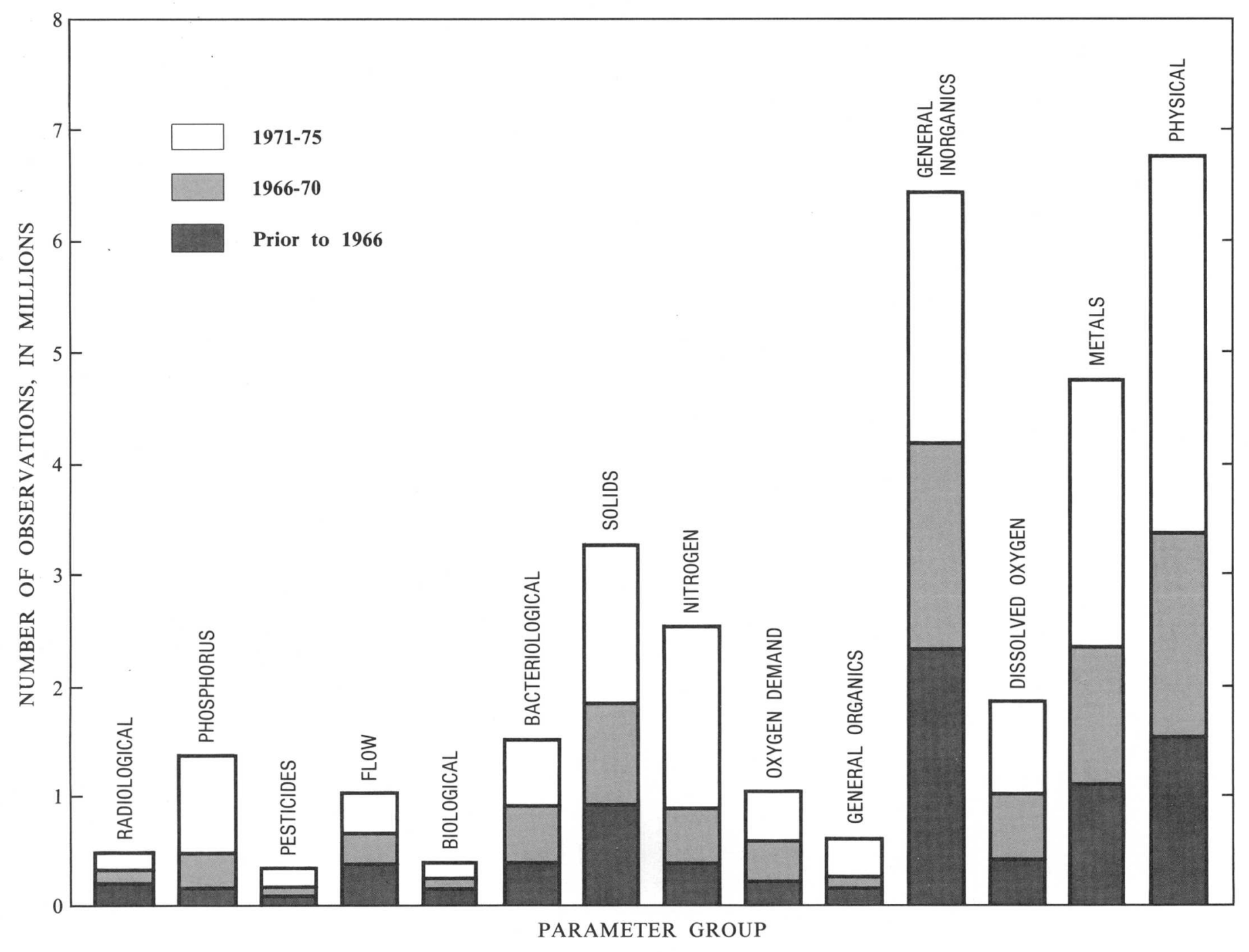

Figure 8.5-1 Parameter groups and number of observations in the Water Quality File. 


\subsection{SUPPLEMENTAL INFORMATION FOR AREA 58}

\subsection{Surface-Water Station Index}

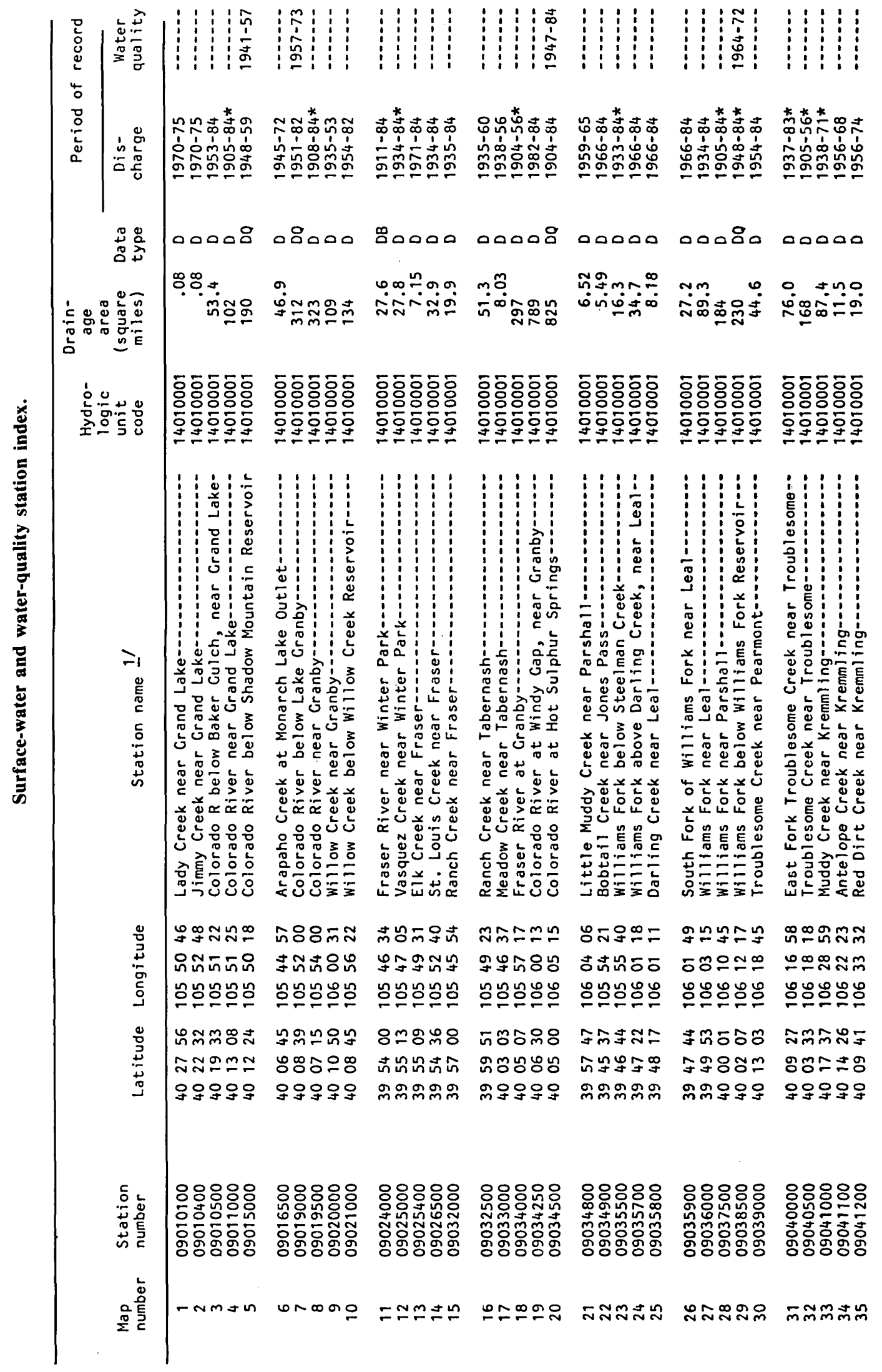




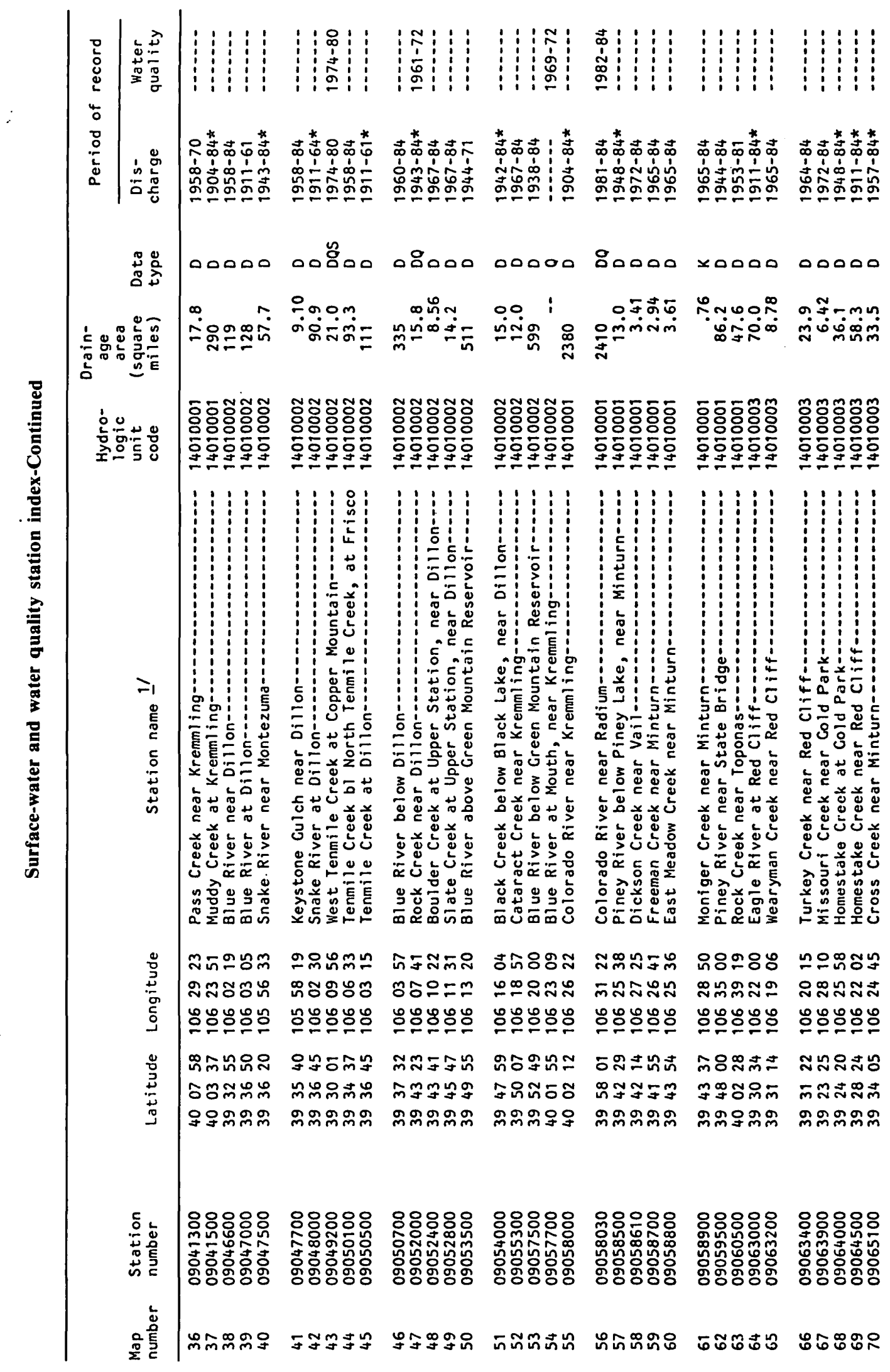

9.0 SUPPLEMENTAL INFORMATION FOR AREA 58--Continued 9.1 Surface-Water Station Index 


\subsection{SUPPLEMENTAL INFORMATION FOR AREA 58--Continued}

9.1 Surface-Water Station Index

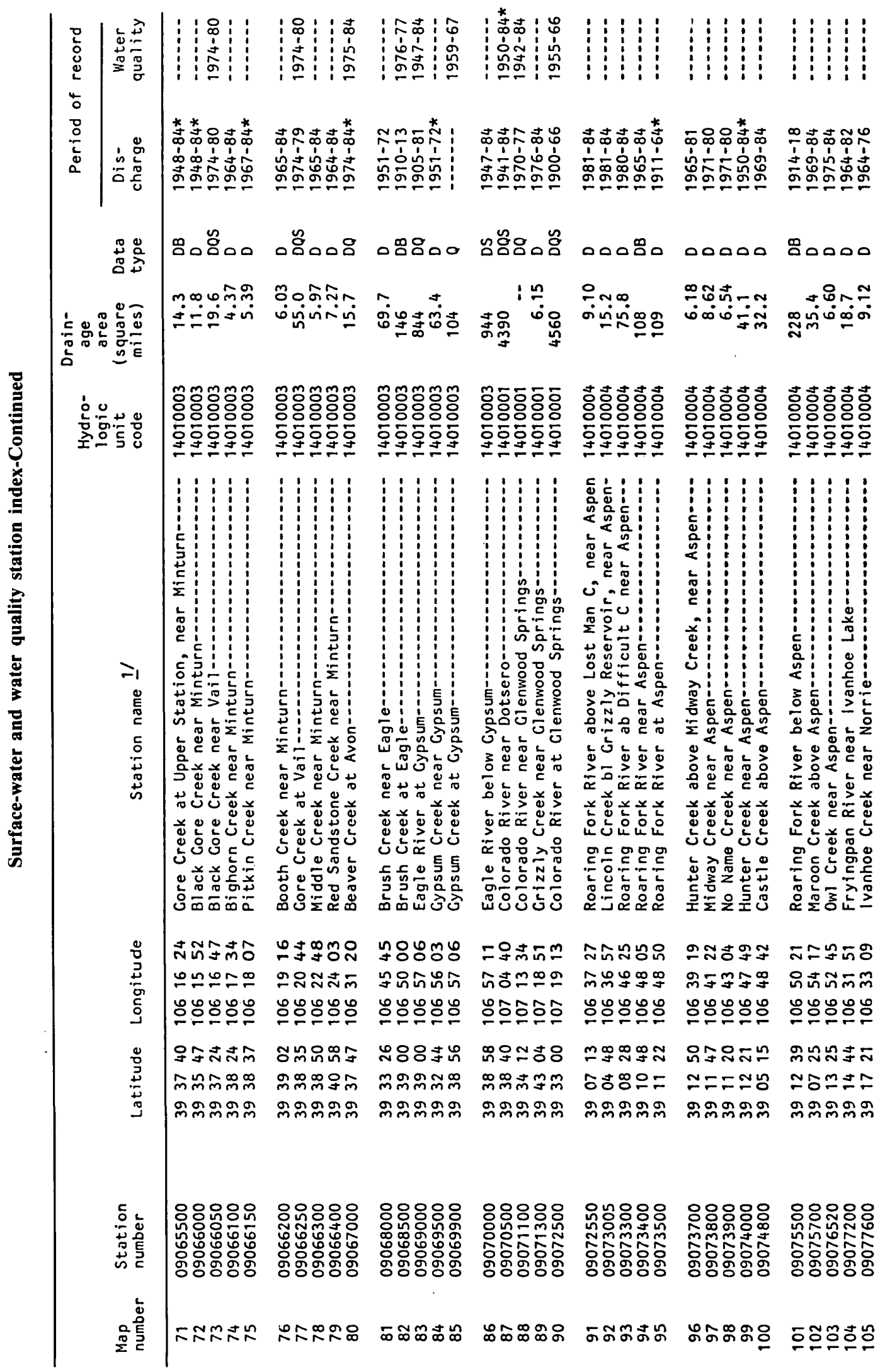




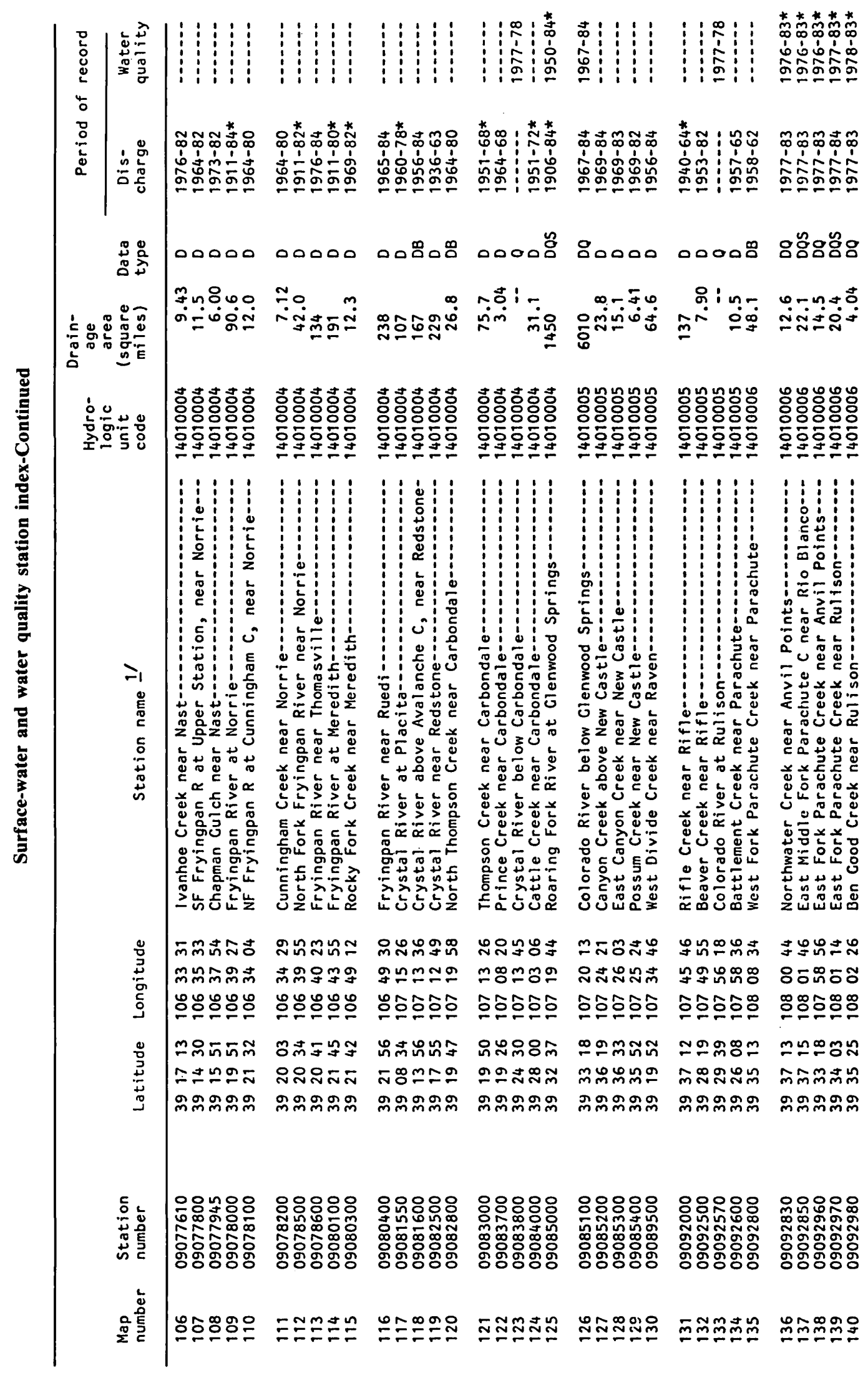

9.0 SUPPLEMENTAL INFORMATION FOR AREA 58--Continued 9.1 Surface-Water Station Index 
9.0 SUPPLEMENTAL INFORMATION FOR AREA 58--Continued

9.1 Surface-Water Station Index

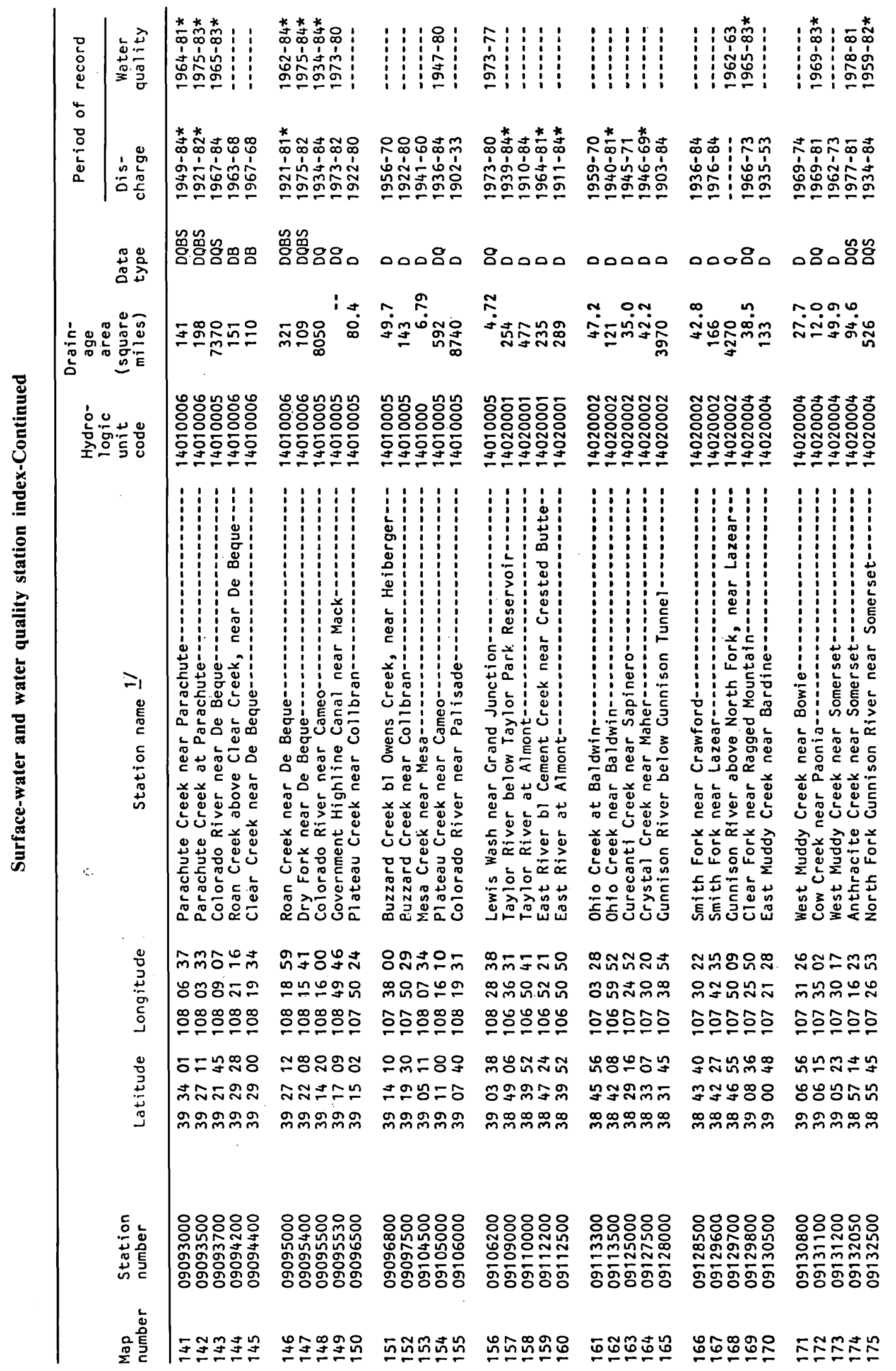




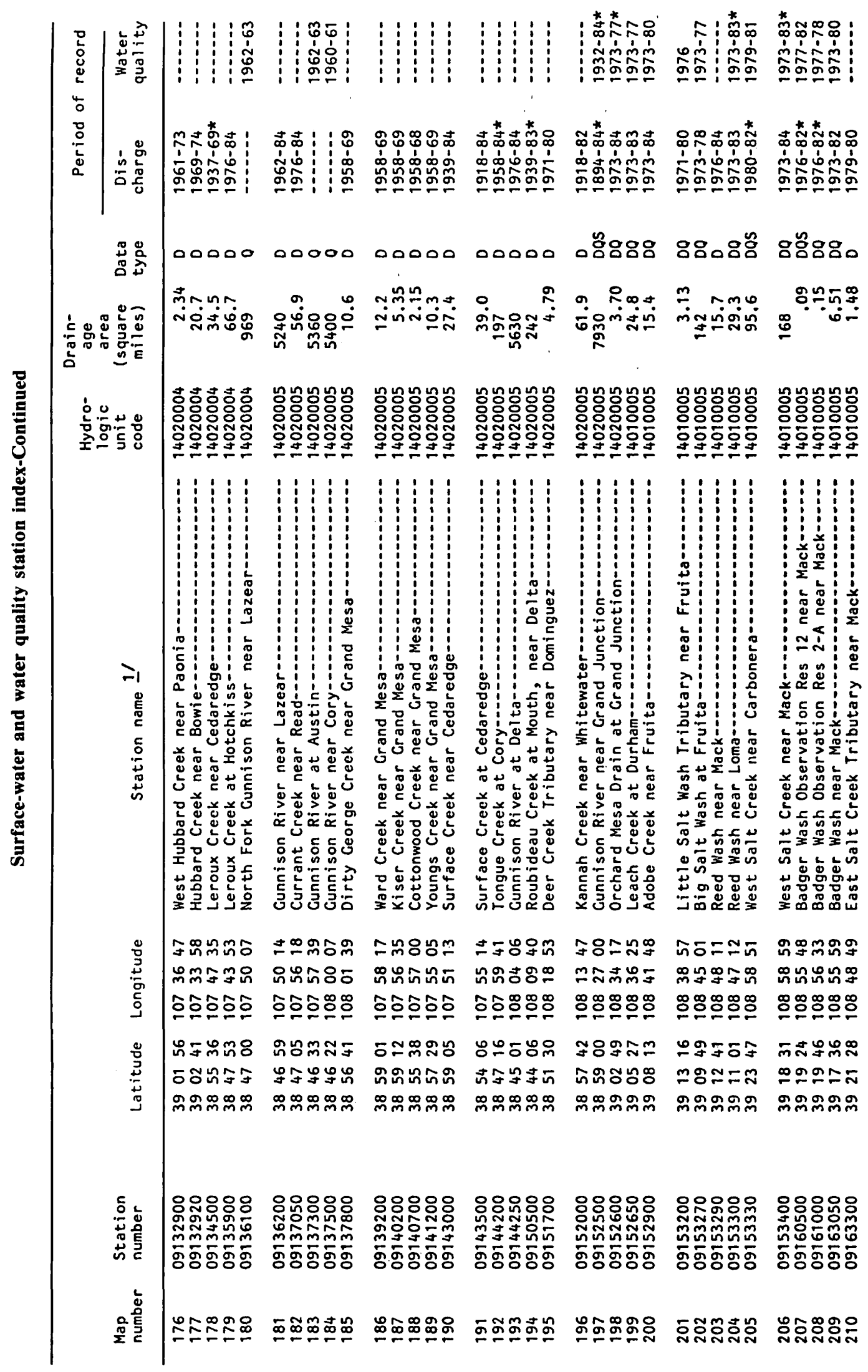

9.0 SUPPLEMENTAL INFORMATION FOR AREA 58--Continued 9.1 Surface-Water Station Index 
9.0 SUPPLEMENTAL INFORMATION FOR AREA 58--Continued

9.1 Surface-Water Station Index

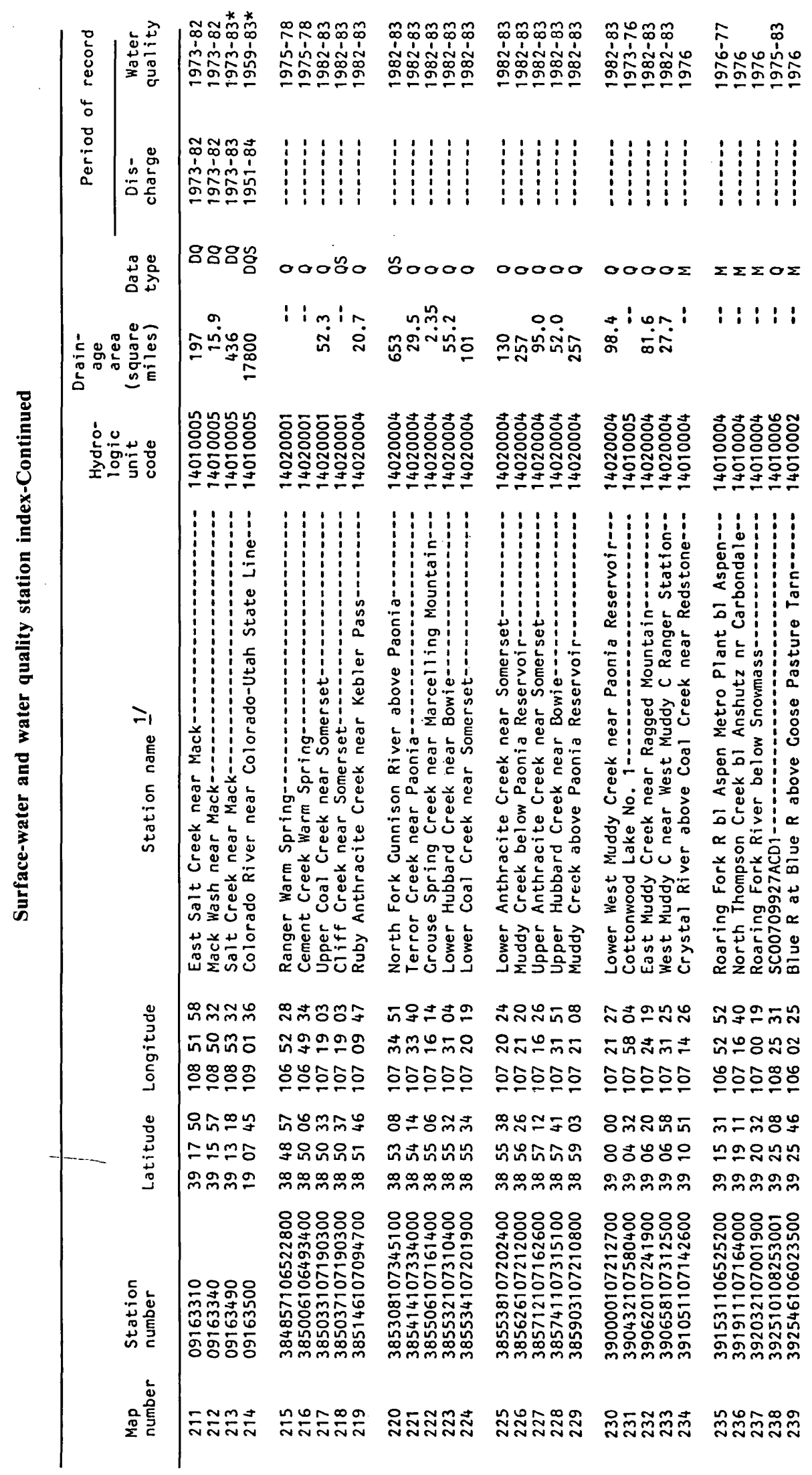




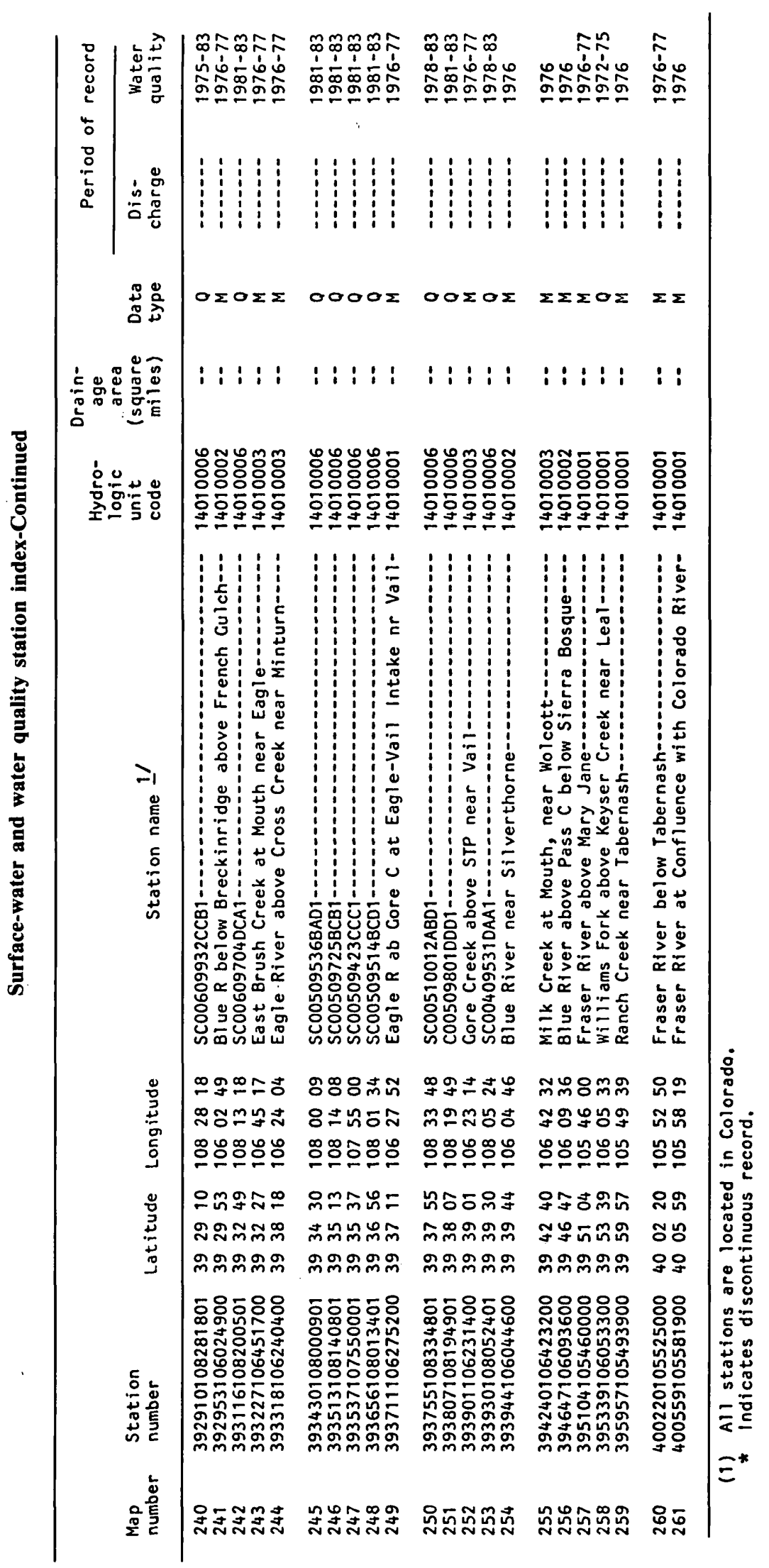

9.0 SUPPLEMENTAL INFORMATION FOR AREA 58--Continued 9.1 Surface-Water Station Index 


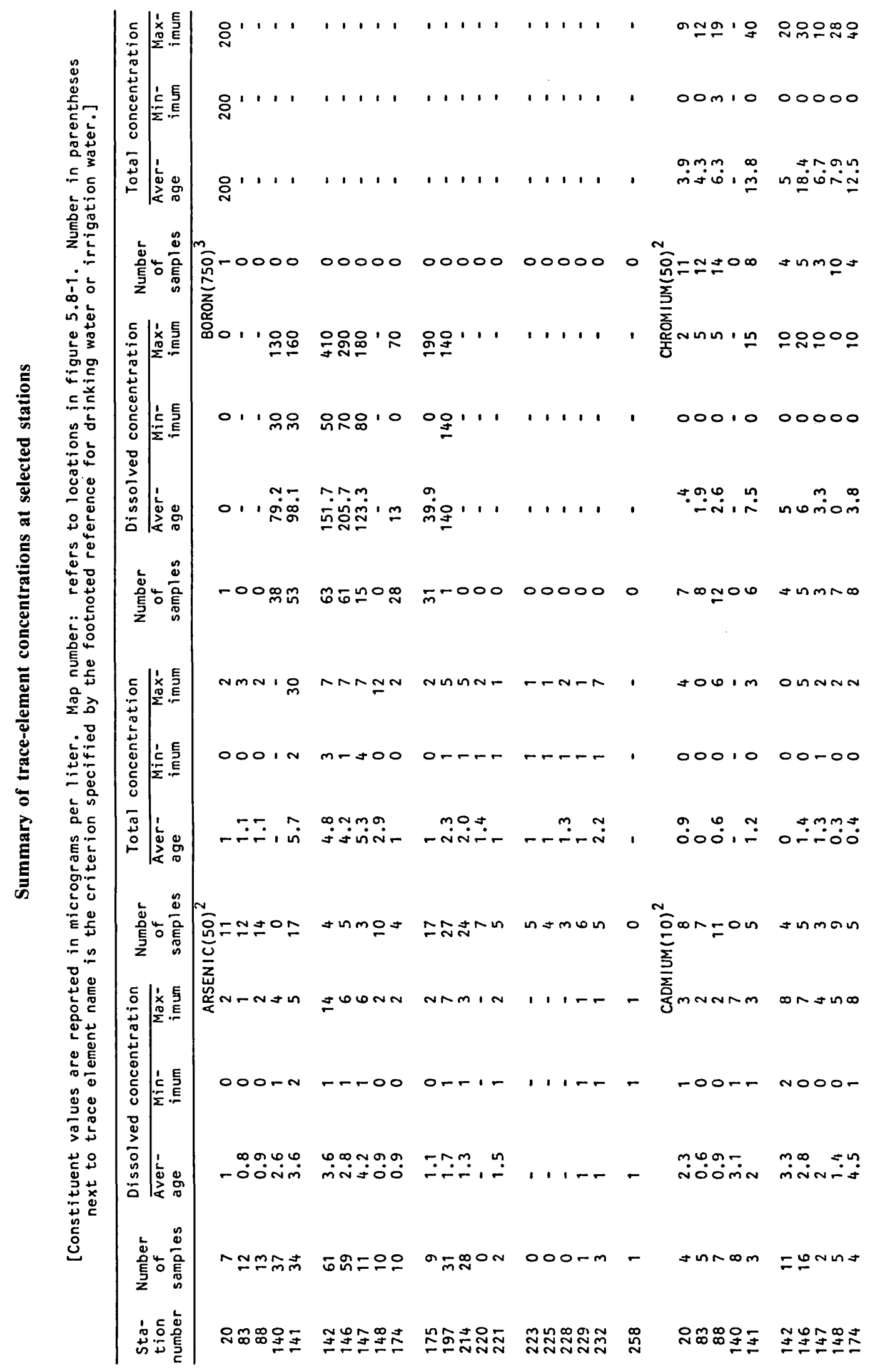




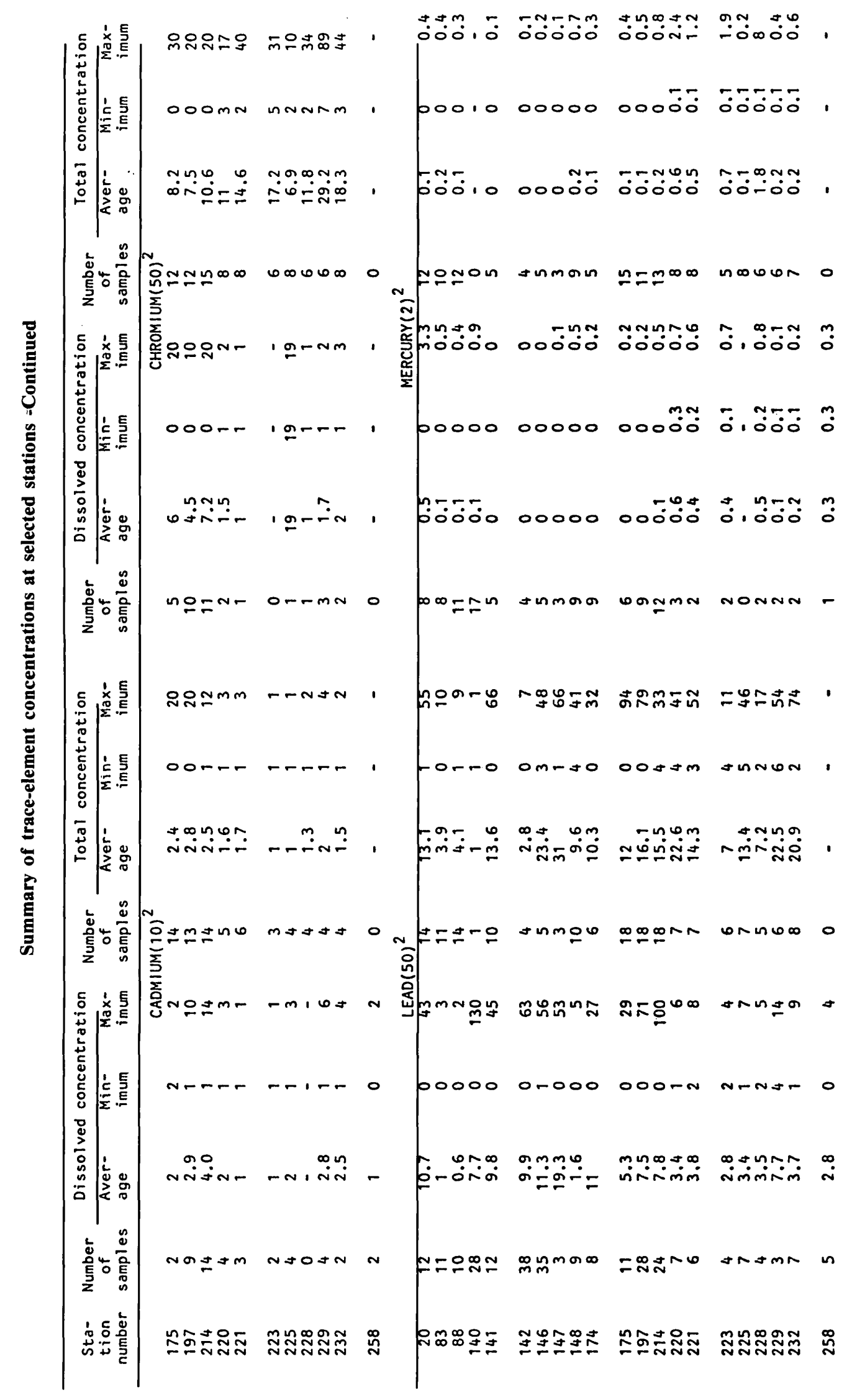

9.0 SUPPLEMENTAL INFORMATION FOR AREA 58--Continued 9.2 Trace-Element Concentrations 
9.0 SUPPLEMENTAL INFORMATION FOR AREA 58--Continued

9.2 Trace-Element Concentrations

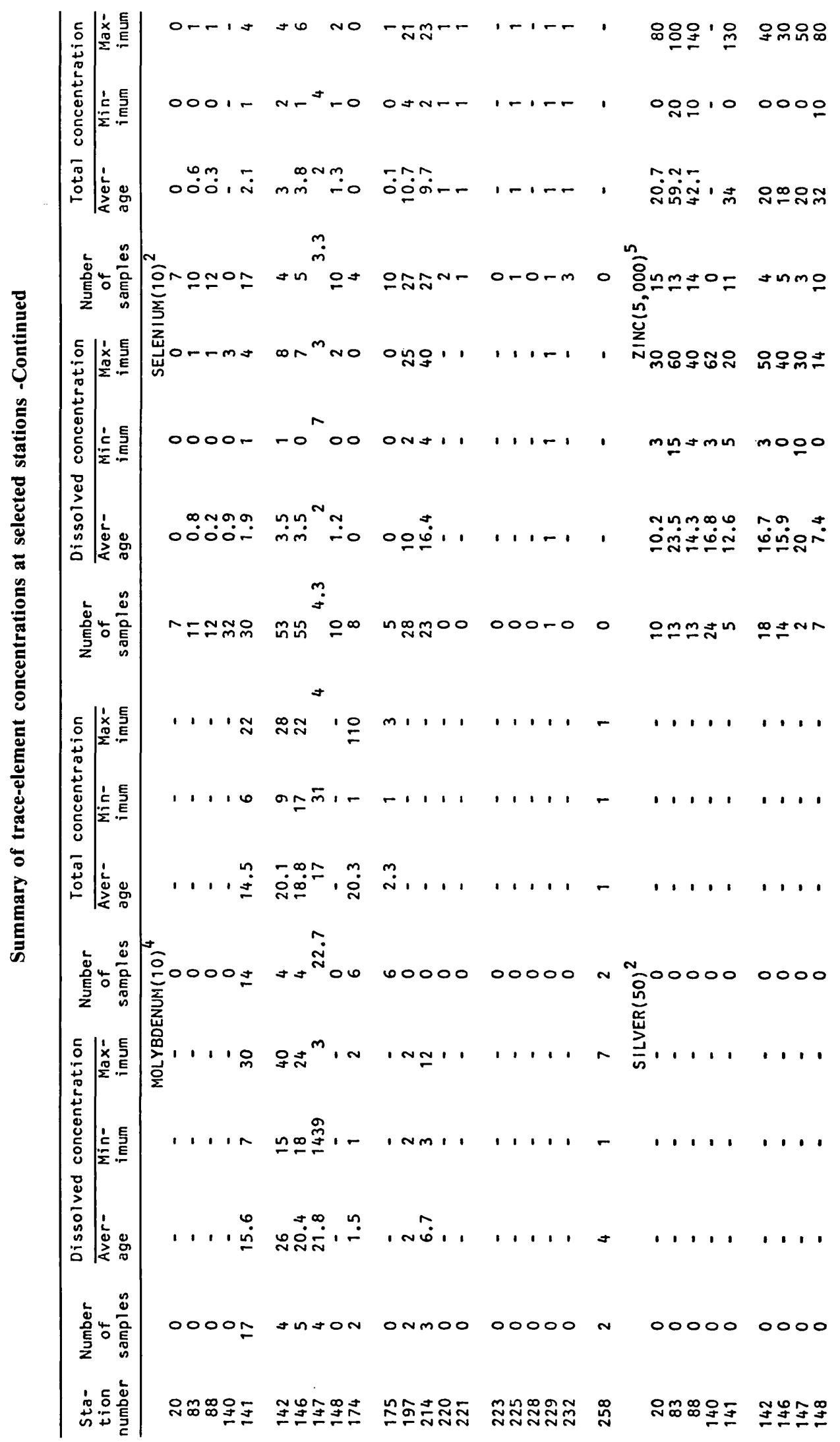




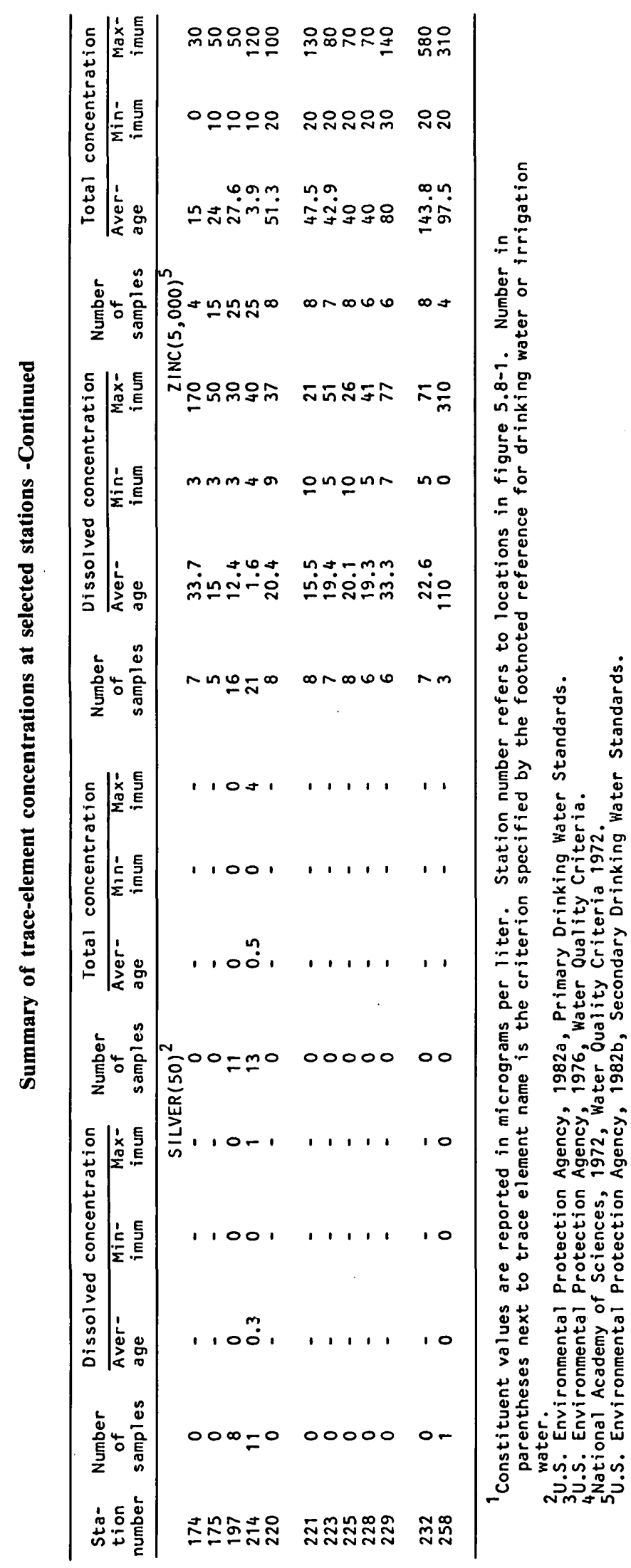

9.0 SUPPLEMENTAL INFORMATION FOR AREA 58--Continued 9.2 Trace-Element Concentrations 


\subsection{SELECTED REFERENCES}

Adams, D.B., Goddard, K.E., Patt, R.O., and Galyean, K.C., (1985), Hydrologic data from Roan and Parachute Creek Basins, northwest Colorado: U.S. Geological Survey Open-File Report 83-859.

Affolter, R.H., and others, 1980, Colorado coal analysis, 1976-1979, Information Series 10: Denver, Colorado Geological Survey, 364 p.

Alley, W.M., Britton, L.J., and Boyd, E.L., 1978a, Reconnaissance evaluation of water resources for hydraulic coal mining, Crested Butte coal field, Gunnison County, Colorado: U.S. Geological Survey Open-File Report 78-938, 23 p.

$1978 \mathrm{~b}$, Reconnaissance evaluation of water resources for hydraulic coal mining, Grand Hogback coal field, Garfield and Rio Blanco Counties, Colorado: U.S. Geological Survey Open-File Report 78-885, $37 \mathrm{p}$.

Alley, W.A., Bauer, D.P., Veenhuis, J.E., and Brennan, Robert, 1979, Hydrologic effects of annually diverting 131,000 acre-feet of water from Dillon Reservoir, central Colorado: U.S. Geological Survey Water-Resources Investigations Report 79-2, 17 p.

Arps, L.W., and Kingery, E.E., 1966, High country names, Rocky Mountain National Park: Denver, The Colorado Mountain Club, 212 p.

Aukerman, Robert, 1975, Feasibility and potential of enhancing water recreation opportunities on high country reservoirs: Colorado State University, Environmental Resources Center Completion Report $62,185 \mathrm{p}$.

Aukerman, Robert, Carlson, C.A., Hiller, R.L., and Labadie, J.W., 1977, Selecting and planning high country reservoirs for recreation within a multipurpose management framework: Colorado State University, Environmental Resources Center, Completion Report 78, $333 \mathrm{p}$.

Benci, J.F., and McKee, T.B., 1977, Colorado monthly temperature and precipitation summary for period 1951-1970: Fort Collins, Colorado State University, Climatology Report 77-1, 300 p.

Berman, A.E., Pooleschook, D., Jr., and Dimelow, T.E., 1980, Jurassic and Cretaceous systems of Colorado, in Kent, H.C., and Porter, K.W., eds., Colorado Geology: Denver, Rocky Mountain Association of Geologists, p. 111-128.

Britton, L.J., 1979, Reconnaissance evaluation of surfacewater quality in Eagle, Grand, Jackson, Pitkin, Routt, and Summit Counties, Colorado: U.S. Geological Survey Open-File Report 79-420, 285 p.

Britton, L.J., and Wentz, D.A., 1980, Water quality characteristics of selected lakes and reservoirs in Colorado: U.S. Geological Survey Open-File Report 80-436, 139 p.

Brogden, R.E., and Giles, T.F., 1976, Availability and chemical quality of ground water in the Crystal River and Cattle Creek drainage basins near Glen- wood Springs, west-central Colorado: U.S. Geological Survey Water-Resources Investigations Report 76-70, 1 sheet, scale 1:125,000.

Brooks, Tom, 1983, Hydrology and subsidence potential of proposed coal-lease tracts in Delta County, Colorado: U.S. Geological Survey Water-Resources Investigations Report 83-4069, 27 p.

Brooks, Tom, and Ackerman, D.J., 1984, Reconnaissance of ground-water resources in the lower Gunnison River basin, southwestern Colorado: U.S. Geological Survey Water-Resources Investigations Report $84-4185,43 \mathrm{p}$.

Buckman, H.O., and Brady, N.C., 1969, The nature and properties of soils: New York, The Macmillan Co., $653 \mathrm{p}$.

Cashion, W.B., 1973, Geologic and structure map of the Grand Junction quadrangle, Colorado and Utah: U.S. Geological Survey Miscellaneous Geologic Investigations Map I-736, scale 1:250,000.

Coffin, D.L., Welder, F.A., and Glanzman, R.K., 1971, Geohydrology of the Piceance Creek structural basin between the White and Colorado Rivers, northwestern Colorado: Washington, D.C., U.S. Geological Survey, Atlas HA-370, 2 sheets, scale $1: 125,000$.

Collier, J.D., Hornbaker, A.L., and Chenoweth, W.L., 1978, Map and directory of Colorado uranium and vanadium mining and milling activities: Denver, Colorado Geological Survey Map Series II, text and sheet, scale 1:500,000.

Collins, B.A., 1976, Coal deposits of the Carbondale, Grand Hogback, and southern Danforth Hills coal fields, eastern Piceance Basin, Colorado: Golden, Colorado School of Mines Quarterly, v. 71, no. 1, $138 \mathrm{p}$.

Colorado Geological Survey and Colorado Division of Planning, 1974, Roaring Fork and Crystal Valleys, an environmental and engineering geology study: Denver, Environmental Geology Series no. 8, 63 p.

Colorado Land Use Commission, 1974a, Existing land use, Colorado, 1973: Denver, 1 sheet, scale $1: 500,000$.

1974b, Land Ownership, Colorado, 1974: Denver, 1 sheet, scale 1:500,000.

Colorado State University, Department of Atmospheric Science, Colorado Climate Center, compiler, 1984, Colorado average annual precipitation 1951-1980: Denver, Colorado, U.S. Geological Survey map, scale 1:500,000.

Covay, K.J., Tobin, R.L., and Stranathan, H.E., (in press), Selected biological characteristics of streams in the Piceance Creek Basin, northwestern Colorado: U.S. Geological Survey Water-Resources Investigations Report 84-4138.

Dean, W.E., Ringrose, C.D., and Klusman, R.W., 1979, Geochemical variation in soils in the Piceance Creek 
Basin, western Colorado: U.S. Geological Survey Bulletin 1479, $47 \mathrm{p}$.

Denver Water Department, 1983, 1982 Annual Report: $78 \mathrm{p}$.

Detroy, M.G., Skelton, J., and others, 1983, Hydrology of area 38, western region, Interior Coal Province, Iowa and Missouri: U.S. Geological Survey WaterResources Investigations Open-File Report 82-1014, $85 \mathrm{p}$.

De Voto, R.H., 1980a, Mississippian stratigraphy and history of Colorado in Kent, H.C., and Porter, K.W., eds., Colorado Geology: Denver, Rocky Mountain Association of Geologists, p. 57-70.

$1980 \mathrm{~b}$, Pennsylvanian stratigraphy and history of Colorado, in Kent, H.C., and Porter, K.W., eds., Colorado Geology: Denver, Rocky Mountain Association of Geologists, p. 71-102.

Down, C.G., and Stocks, J., 1977, Environmental impact of mining: New York, Halsted Press, $371 \mathrm{p}$.

Dunne, Thomas, and Leopold, L.B., 1978, Water in environmental planning: San Francisco, W.H. Freeman and Co., 818 p.

Dunrud, C.R., 1976, Some engineering geologic factors controlling coal mine subsidence in Utah and Colorado: U.S. Geological Survey Professional Paper $969,39 \mathrm{p}$.

Ebens, R.J., and Shacklette, H.T., 1982, Geochemistry of some rocks, mine spoils, stream sediments, soils, plants, and waters in the western energy region of the conterminous United States: U.S. Geological Survey Professional Paper 1237, 173 p.

Elliott, J.G., Jarrett, R.D., and Ebling, J.L., 1982, Annual snowmelt and rainfall peak-flow data on selected foothills region streams, South Platte River, Arkansas River, and Colorado River basins, Colorado: U.S. Geological Survey Open-File Report $82-426,86$ p.

Fenneman, N.M., 1931, Physiography of western United States: New York, McGraw-Hill, 534 p.

Fenneman, N.M., and Johnson, D.W., 1946, Physical divisions of the United States: U.S. Geological Survey Physiographic Committee, 1 sheet, scale $1: 7,000,000$.

Ficke, J.F., Adams, D.B., and Danielson, T.W., 1977, Evaporation from seven reservoirs in the Denver water-supply system, central Colorado: U.S. Geological Survey Water-Resources Investigations $76-114,170 \mathrm{p}$.

Galyean, K.C., Adams, D.B., and Collins, D.L., 1985, Hydrologic data from naval oil-shale reserves, Parachute Creek basin, northwest Colorado, 1980-81: U.S. Geological Survey Open-File Report $83-858,70 \mathrm{p}$.

Gaydos, M.W., 1980, Summary of water-quality data for selected streams in Colorado: U.S. Geological Survey Open-File Report 80-682, 148 p.

Giles, T.F., 1980, Reconnaissance of ground-water resources in the vicinity of Gunnison and Crested
Butte, west-central Colorado: U.S. Geological Survey Water-Resources Investigations Open-File Report 80-12, 1 sheet, scale 1:125,000.

Giles, T.F., and Brogden, R.E., 1976, Water-quality data for the Eagle River valley in the vicinity of Eagle and Vail, west-central Colorado: U.S. Geological Survey Open-File Report 76-812, 1 sheet, scale $1: 125,000$.

Goolsby, S.M., Reade, N.S., and Murray, D.K., 1979, Evaluation of coking coals in Colorado: Denver, Colorado Geological Survey Resource Series 7, $72 \mathrm{p}$.

Gough, L.P., Shacklette, H.T., and Case, A.A., 1979, Element concentrations toxic to plants, animals, and man: U.S. Geological Survey Bulletin 1466, 80 p.

Guy, H.P., and Norman, V.W., 1970, Field methods for measurement of fluvial sediment, Book 3, chap. C2, Applications of Hydraulics: U.S. Geological Survey Techniques of Water-Resources Investigations, $59 \mathrm{p}$.

Hansen, W.R., 1965, The Black Canyon of the Gunnison today and yesterday: U.S. Geological Survey Bulletin 1191, $76 \mathrm{p}$.

Hawkinson, R.O., and Lystrom, D.J., compilers, 1983, Water-resources investigations of the U.S. Geological Survey in Colorado-fiscal year 1983: U.S. Geological Survey Open-File Report 83-138, 79 p.

Hedman, E.R., and Osterkamp, W.R., 1982, Streamflow characteristics related to channel geometry of streams in western United States: U.S. Geological Survey Water-Supply Paper 2193, 17 p.

Heil, R.D., Romine, D.S., Moreland, D.C., Dansdill, R.K., Montgomery, R.H., and Cipra, J.E., 1977, Soils of Colorado: Fort Collins, Colorado State University Experiment Station, Bulletin 566S, 39 p.

Hem, J.D., 1970, Study and interpretation of the chemical characteristics of natural water: U.S. Geological Survey Water-Supply Paper 1473, 363 p.

Herbert, R.A., 1983, An assessment of the hydrologic information required for the U.S. Bureau of Land Management-U.S. Geological Survey coal-hydrology program in the west: U.S. Geological Survey OpenFile Report 82-1012, 28 p.

Howard, C.W., 1955, Quality of water of the Colorado River, 1925-1940: U.S. Geological Survey Open-File Report, $103 \mathrm{p}$.

Hunt, C.B., 1969, Geologic history of the Colorado River, in The Colorado River Region and John Wesley Powell: U.S. Geological Survey Professional Paper 669-C, p. 59-130.

1972, Geology of soils; their evolution, classification, and uses: San Francisco, W.H. Freeman and Co., $344 \mathrm{p}$.

Inman, R.R., Olson, D.C., and King, D.L., 1984, Grand Valley salt pick-up calculations, in French, R.H., ed., Salinity in water courses and reservoirs: Ann Arbor, Michigan, Butterworth Publishers, p. 157-167.

Iorns, W.V., Hembree, C.H., and Oakland, G.L., 1965, Water resources of the Upper Colorado River Basin-Technical report: U.S. Geological Survey 
Professional Paper 441, 370 p.

Iorns, W.V., Hembree, C.H., Phoenix, D.A., and Oakland, G.L., 1964, Water resources of the Upper Colorado River Basin-basic data: U.S. Geological Survey Professional Paper 442, 1036 p.

Jarrett, R.D., and Costa, J.E., 1982, Multidisciplinary approach to the flood hydrology of foothill streams in Colorado, in Johnson, A.I., and Clark, R.A., eds., International Symposium on Hydrometerology: American Water Works Association, 1982, p. 565-569.

Kent, H.C., and Porter, K.W., eds., 1980, Colorado geology: Denver, Rocky Mountain Association of Geologists 1980 Symposium, 258 p.

Khalsa, N.A., and Ladwig, L.R., 1981, Colorado coal analyses 1976-1979: Colorado Geological Survey Information Series No. 10, Denver, 364 p.

Kircher, J.E., Dinicola, R.S., and Middelburg, R.F., 1984, Trend analysis of salt load and evaluation of the frequency of water-quality measurements for the Gunnison River in Colorado and the Dolores River in Colorado and Utah: U.S. Geological Survey WaterResources Investigations Report 84-4048, 69 p.

Kircher, J.E., Choquette, A.F., and Richter, B.D., (1985), Estimation of natural streamflow characteristics: U.S. Geological Survey Water-Resources Investigations Report 85-4086.

Ladwig, L.R., 1983, 1981 summary of coal resources in Colorado: Denver, Colorado Geological Survey Special Publication 23, 22 p.

Landis, E.R., 1959, Coal resources of Colorado: U.S. Geological Survey Bulletin 1072-C, 131 p.

Lee, F.T., and Abel, J.F., Jr., 1983, Subsidence from underground mining, environmental analysis and planning considerations: U.S. Geological Survey Circular 876, $28 \mathrm{p}$.

Livingston, R.K., 1970, Evaluation of the streamflow data program in Colorado: U.S. Geological Survey open-file report, $72 \mathrm{p}$.

Lohman, S.W., 1981, The geologic story of Colorado National Monument: U.S. Geological Survey Bulletin 1508, $142 \mathrm{p}$.

1965, Geology and artesian water supply, Grand Junction area, Colorado: U.S. Geological Survey Professional Paper 451, 149 p.

McCain, J.F., and Ebling, J.L., 1979, A plan for study of flood hydrology of foothill streams in Colorado: U.S. Geological Survey Open-File Report 79-1276, $29 \mathrm{p}$.

McCain, J.F., and Jarrett, R.D., 1976, Manual for estimating flood characteristics of natural-flow streams in Colorado: Denver, Colorado Water Conservation Board Technical Manual 1, 57 p.

Martin, R.O.R., and Hanson, R.L., 1966, Reservoirs in the United States: U.S. Geological Survey WaterSupply Paper 1838, 115 p.

Maughan, E.K., 1980, Permian and lower Triassic geology of Colorado, in Kent, H.C., and Porter, K.W., eds., Colorado Geology: Denver, Rocky Mountain Association of Geologists, p. 103-110.

Mehls, S.F., 1982, The valley of opportunity, a history of west-central Colorado: Denver, Colorado, U.S. Bureau of Land Management, Colorado State Office Cultural Resource Series no. 12, 352 p.

Miller, J.F., Frederick, R.H., and Tracey, R.J., 1973, Precipitation-frequency atlas of the western United States, v. 3-Colorado; v. 6-Utah: U.S. Department of Commerce, NOAA Atlas 2.

Moore, D.D., 1968, Estimating mean runoff in ungaged semiarid areas: Bulletin of the International Association of Scientific Hydrology, no. 1, p. 29-39.

Moran, R.E., and Wentz, D.A., 1974, Effects of metalmine drainage on water quality in selected areas of Colorado, 1972-1973: Denver, Colorado Water Conservation Board Water Resources Circular 25, 250 p.

Morse, J.G., 1979, Energy resources in Colorado: coal, oil shale, and uranium: Boulder, Colorado, Westview Press, $396 \mathrm{p}$.

Mueller, D.K., and Moody, C.D., 1984, Historical trends in concentration and load of major ions in the Colorado River system, in French, R.H., ed. Salinity in water-courses and reservoirs: Ann Arbor, Michigan, Butterworth Publishers, p. 181-192.

Murray, D.K., ed., 1977, Geology of Rocky Mountain Coal-1976 Symposium: Denver, Colorado Geological Survey, 175 p.

Upper Cretaceous (Campanian) coal resources of western Colorado, in Epis, R.C., and Callendar, J.F., eds., western Colorado and eastern Utah: Socorro, New Mexico Geological Society Guide Book, 32nd Field Conference, p. 233-240.

Murray, D.K., Fender, H.B., and Jones, D.C., 1977, Coal and methane gas in the southeastern part of the $\mathrm{Pi}$ ceance Creek Basin, Colorado, in Veal, H.K., ed., Exploration frontiers of the central and southern Rockies: Denver, Rocky Mountain Association of Geologists, p. 379-405.

National Academy of Sciences, 1972 [1973], Water quality criteria, 1972: Washington, D.C., U.S. Environmental Protection Agency, EPA-R3-033, 594 p.

National Academy of Sciences, 1974, Geochemistry and the environment, the relation of selected trace elements to health and disease: Washington, D.C., v. 1,113 p.

Newman, K.R., 1980, Geology of oil shale in Piceance Creek basin, Colorado, in Kent, H.C., and Porter, K.W., eds., Colorado Geology: Denver, Rocky Mountain Association of Geologists, p. 199-204.

Norris, J.M., and Maura, W.S., 1985, Water-quality data for streams in the Upper North Fork of the Gunnison River, Colorado: U.S. Geological Survey Open-File Report 85-190, 122 p.

O'Rourke, P.M., 1980, Frontier in transition, a history of southwestern Colorado: U.S. Bureau of Land Management, Colorado State Office, Cultural Resource Series, no. 10, 202 p. 
Patt, R.O., Adams, D.B., and Collins, D.L., 1982, Hydrologic data from naval oil shale reserves, Parachute Creek Basin, northwestern Colorado, 1975-1979: U.S. Geological Survey Open-File Report 82-696, 129 p.

Patterson, J.L., and Somers, W.P., 1966, Magnitude and frequency of floods in the United States, Part 9, Colorado River basin: U.S. Geological Survey WaterSupply Paper 1683, 475 p.

Petsch, H.E., Jr., 1980, Streamflow statistical summaries for Colorado streams through September 30, 1975, v. 2, Colorado River basin above Gunnison River: U.S. Geological Survey Open-File Report 79-1060, 350 p.

1983, Streamflow statistical summaries for Colorado streams through September 30, 1975, v. 3, Colorado River basin from Gunnison River to San Juan River: U.S. Geological Survey Open-File Report 83-693, 436 p.

Porterfield, George, 1972, Computation of fluvial sediment discharge: U.S. Geological Survey Techniques of Water-Resources Investigations, Book 3, chap. C3, $65 \mathrm{p}$.

Rantz, S.E., and others, 1982, Measurement and computation of streamflow: U.S. Geological Survey Water-Supply Paper 2175, 2 v.

Richter, B.D., and others, 1984, Summary of basin streamflow characteristics for selected basins in western Colorado and adjacent states: U.S. Geological Survey Open-File Report 84-137, 266 p.

Riggs, H.C., 1968a, Some statistical tools in hydrology: U.S. Geological Survey Techniques of WaterResources Investigations, Book 4, chap. A1, 39 p. 1968b, Frequency curves: U.S. Geological Survey Techniques of Water Resources Investigations, Book 4, chap. A2, 15 p.

1969, Mean streamflow from discharge measurements: Bulletin of the International Association of Scientific Hydrology, no. 14, p. 95-110.

1972, Low-flow investigations: U.S. Geological Survey Techniques of Water-Resources Investigations, Book 4, chap. B1, $18 \mathrm{p}$.

1973, Regional analysis of streamflow characteristics: U.S. Geological Survey Techniques of Water-Resources Investigations, Book 4, chap. B3, $15 \mathrm{p}$.

Riggs, H.C., and Hardison, C.H., 1973, Storage analysis for water supply: U.S. Geological Survey Techniques of Water-Resources Investigations, Book 4, chap. B2, $20 \mathrm{p}$.

Riggs, H.C., and Moore, D.O., 1965, A method of estimating mean runoff from ungaged basins in mountainous regions, in U.S. Geological Survey Professional Paper 525-D: p. D199-D202.

Ross, R.J., and Tweto, Ogden, 1980, Lower Paleozoic sediments and tectonics in Colorado, in Kent, H.C., and Porter, K.W., eds., Colorado Geology: Denver,
Rocky Mountain Association of Geologists, p. 47-56. Rushworth, Peter, 1984, Bibliography-coal resources, Uinta Region: Denver, Colorado Geological Survey Open-File Report 84-1, 32 p.

Rushworth, Peter, Kelso, B.S., and Ladwig, L.R., 1984, Map, directory and statistics of permitted Colorado coal mines, 1983: Denver, Colorado Geological Survey Map Series 23, 146 p.

Scanlon, A.H., 1982, Oil and gas fields of Colorado, statistical data through 1981: Denver, Colorado Geological Survey Information Series 18, 72 p.

Schwochow, S.D., 1981, Inventory of nonmetallic mining and processing operations in Colorado: Denver, Colorado Geological Survey Map Series 17, 39 p.

Searcy, J.K., 1959, Flow-duration curves: U.S. Geological Survey Water-Supply Paper 1542-A, 33 p.

Shen, H.W., and others, 1981, Role of sediment in nonpoint source salt loading within the Upper Colorado River Basin: Fort Collins, Colorado Water Resources Research Institute, Completion Report no. 107, $213 \mathrm{p}$.

Snow, Don, 1983, Physical and chemical characteristics of coal, in Coal development, collected papers, v. 1: Missoula, University of Montana, p. 159-200.

Solley, W.B., Chase, E.B., and Mann W.B.,IV, 1983, Estimated use of water in the United States in 1980: U.S. Geological Survey Circular 1001, 56 p.

Spahr, N.E., and Ruddy, B.C., 1983, Reservoir evaporation in central Colorado: U.S. Geological Survey Water-Resources Investigations Report 83-4103, $232 \mathrm{p}$.

Speltz, C.N., 1976, Strippable coal resources of Colorado-location, tonnage, and characteristics of coal and overburden: U.S. Bureau of Mines Information Circular 8713, $70 \mathrm{p}$.

Striffler, W.D., and Rhodes, R.A., 1981, Hydrologic and erosional characteristics of regraded surface coalmined land in Colorado: Fort Collins, Colorado State University, Earth Resources Department, 81 p.

Taylor, O.J., 1982a, Three-dimensional mathematical model for simulating the hydrologic system in the Piceance basin, Colorado: U.S. Geological Survey Water-Resources Investigations Open-File Report 82-637, 35 p.

$1982 \mathrm{~b}$, compiler, Hydrologic information needs for oil-shale development, northwestern Colorado: U.S. Geological Survey Water-Resources Investigations Report 82-4076, $92 \mathrm{p}$.

Thomas, D.M., and Benson, M.A., 1970, Generalization of streamflow characteristics from drainage-basin characteristics: U.S. Geological Survey WaterSupply Paper 1975, 55 p.

Thornbury, W.D., 1965, Regional geomorphology of the United States: New York, John Wiley, 609 p.

Turk, J.T., and Parker, R.S., 1982, Water-quality characteristics of six small, semiarid watersheds in the Green River coal region of Colorado: U.S. Geological Survey Water-Resources Investigations 
81-19, 96 p.

Tweto, Ogden, 1977, Tectonic history of west-central Colorado, in Veal, H.K., ed., Exploration frontiers of the central and southern Rockies: Denver, Rocky Mountain Geological Survey Guidebook Series, p. 11-22. 1979, Geologic Map of Colorado: U.S. Geological Survey, 2 sheets, scale 1:500,000. 1980a, Tectonic history of Colorado, in Kent, H.C., and Porter, K.W., eds., Colorado Geology: Denver, Rocky Mountain Association of Geologists, p. 11-22.

$1980 b$, Precambrian Geology of Colorado, in Kent, H.C., and Porter, K.W., eds., Colorado Geology: Denver, Rocky Mountain Association of Geologists, p. 37-46.

1980c, Summary of Laramide Orogeny in Colorado, in Kent, H.C., and Porter, K.W., eds., Colorado Geology: Denver, Rocky Mountain Association of Geologists, p.129-134.

Tweto, Ogden, Moench, R.H., and Reed, J.C., Jr., 1978, Geologic map of the Leadville $1^{\circ} \times 2^{\circ}$ quadrangle, northwestern Colorado: U.S. Geological Survey Miscellaneous Investigations Series Map I-999, scale $1: 250,000$.

Tweto, Ogden, Steven, T.A., Hall, W.J., Jr., and Moench, R.H., 1976, Preliminary geologic map of the Montrose $1^{\circ} \times 2^{\circ}$ quadrangle, southwestern Colorado: U.S. Geological Survey Miscellaneous Field Studies Map MF-761, scale 1:250,000.

URS Corporation, 1981, Problem identification and quantification, salinity investigation of Glenwood Springs-Dotsero unit: Denver, 98 p.

U.S. Bureau of Land Management, 1979, West-central Colorado coal, final environmental impact statement 79-20: $3 \mathrm{v}$.

1983a, Final environmental impact statement, Glenwood Springs Resource Management Plan, 315 p.

1983b, Payments in lieu of taxes--1983:

Denver, Colorado State Office, 25 p. 1984, Public land statistics--1983: Washington, D.C., $231 \mathrm{p}$.

U.S. Bureau of Reclamation, no date, Colorado-Big Thompson Project: U.S. Department of Interior, pamphlet, $4 \mathrm{p}$.

1981, Project data in U.S. Department of Interior, $1463 \mathrm{p}$.

1983, Quality of water, Colorado River basin: U.S. Department of the Interior Report no. $11,148 \mathrm{p}$.

U.S. Department of Commerce, Bureau of the Census, April 1982, 1980, Census of population, general population characteristics, part 7, Colorado: Washington, D.C., U.S. Government Printing Office, 196 p.

U.S. Environmental Protection Agency, 1976, Quality criteria for water: Washington, D.C., U.S. Government Printing Office, $256 \mathrm{p}$. 1977a, National interim primary drinking water regulations, Washington, D.C., EPA570/9-76-003: 159 p.

1977b, National secondary drinking water regulations (proposed): Federal Register, volume 42, no. 62, March 31, Part I, p. 17143-17147.

1982a, Maximum contaminant levels, Part 141 , subpart B, National interim primary drinking water regulations: U.S. Code of Federal Regulations, Title 40, Parts 100-149, revised July 1, 1982, p. 315-318.

$1982 \mathrm{~b}$, Secondary maximum contaminant levels, section 143.3, Part 143, National secondary drinking water regulations: U.S. Code of Federal Regulations, Title 40, Parts 100-149, revised July, 1,1982 , p. 374.

U.S. Forest Service, 1976, Grand Mesa National Forest, map: scale 1:126,720.

U.S. Geological Survey, 1954, Compilation of records of surface waters of the United States through September 1950-Part 9, Colorado River basin: U.S. Geological Geological Survey Water-Supply Paper 1313, $755 \mathrm{p}$.

1961, Physiographic and hydraulic studies of rivers, 1956-1961: Professional Paper 282, 209 p.

1964, Compilation of records of surface waters of the United States, October 1950 to September 1960-Part 9, Colorado River basin: U.S. Geological Survey Water-Supply Paper 1733, 602 p. 1970, Surface water supply of the United States, 1961-65-Part 9, Colorado River basinVolume 1, Colorado River basin above Green River: U.S. Geological Survey Water-Supply Paper 1924, $496 \mathrm{p}$.

1971-1974, Water resources data for Colorado, Part 1. Surface water records: Lakewood, Colo., $4 \mathrm{v}$.

1973, Surface water supply of the United States, 1966-70-Part 9, Colorado River basinVolume 2, Colorado River basin above Green River: U.S. Geological Survey Water-Supply Paper 2124, $551 \mathrm{p}$.

1974, Colorado hydrologic unit map: Reston, Va., 1 sheet, scale 1:500,000.

1975-1977, Water resources data for Colorado, v. 2, Colorado River Basin and Delores River: Lakewood, Colo., 3 v.

1978-1983, Water resources data for Colorado, v. 2, Colorado River Basin above Delores River: Lakewood, Colo., 6 v.

1982, A U.S. Geological Survey standard, codes for the identification of hydrologic units in the United States and the Caribbean outlying areas: U.S. Geological Survey Circular 878-A, 114 p.

U.S. Geological Survey, and Colorado Geological Survey, 1977, Energy resources of Colorado: 1 sheet, scale 1:500,000.

U.S. National Committee for Geochemistry, 1980, Trace- 
element geochemistry of coal resource development related to environmental health and quality: Washington, D.C., National Academy Press, 153 p.

U.S. National Oceanic and Atmospheric Administration, 1978, Climates of the states: Detroit, Michigan, Gale Research Co., 2 v.

1980, Climates of the States, 2nd edition: Detroit, Michigan, Gale Research Co., 2 v.

1981, Environmental data and information service, climatological data-annual summary, Colorado, 1981 , v. 86 , no. 13,19 p.

U.S. National Research Council, Committee on Disposal of Excess Spoil, 1981, Disposal of excess spoil from coal mining and the Surface Mining Control and Reclamation Act of 1977: Washington, D.C., National Academy Press, 207 p.

U.S. Soil Conservation Service, 1975, Soil taxonomy-a basic system of soil classification for making interpretive soil surveys: Washington, D.C., U.S. Department of Agriculture Handbook No. 436, 754 p.

U.S. Water Resources Council, 1982, Guidelines for determining flood flow frequency: Washington, D.C., Government Printing Office, Revised Bulletin 17B, $28 \mathrm{p}$.

Voegeli, P.T., 1965, Ground-water resources of North Park and Middle Park, Colorado-A reconnaissance: U.S. Geological Survey Water-Supply Paper 1809-G, 54 p.

Wali, M.K., ed., 1978, Ecology and coal resource development: Pergamon Press, v. 1, 540 p.
Wallace, Arthur and Berry, W.L., 1979, Trace elements in the environment-effects and potential toxicity of those associated with coal, in Wali, M.K., ed., Ecology and coal resource development: New York, Pergamon Press, p. 95-114.

Walsh, R.G., 1980, Empirical application of a model for estimating the recreation value of water in reservoirs compared to instream flow: Ft. Collins, Colorado State University, Water Resources Research Institute Completion Report 103, 60 p.

Walsh, R.G., Aukerman, Robert, and Milton, Robert, 1980, Measuring benefits and the economic value of water in recreation on high country reservoirs: Ft. Collins, Colorado State University, Water Research Institute Completion Report 102, 50 p.

Washichek, J.N., Moreland, R.E., and Teilborg, J.R., 1972, Summary of snow measurements for Colorado and New Mexico 1936-1972: U.S. Soil Conservation Service, 208 p.

Washichek, J.N., Shafer, B.A., and Teilborg, J.R., 1978, Summary of snow survey measurements for Colorado and New Mexico, 1971-1977: U.S. Soil Conservation Service, $128 \mathrm{p}$.

Wentz, D.A., 1974, Effect of mine drainage on the quality of streams in Colorado, 1971-1972: Denver, Colorado Water Resources Circular 21, $117 \mathrm{p}$.

Wilson, L., and others, 1975, Soils of Utah: Logan, Utah State University, Experiment Station, Bulletin 492, $94 \mathrm{p}$. 